UNIVERSIDADE DE SÃO PAULO

Faculdade de Filosofia, Letras e Ciências Humanas

Departamento de Teoria Literária

Lígia Razera Gallo

\title{
O desequilíbrio familiar e a identidade americana nas peças de Sam Shepard
}

São Paulo

2011 


\section{UNIVERSIDADE DE SÃO PAULO}

Faculdade de Filosofia, Letras e Ciências Humanas

Departamento de Teoria Literária

Lígia Razera Gallo

\section{O desequilíbrio familiar e a identidade americana nas peças de Sam Shepard \\ (versão corrigida)}

São Paulo

2011

Ligia Razera Gallo 


\section{O desequilíbrio familiar e a identidade americana nas peças de Sam Shepard}

Tese apresentada ao Departamento de Letras Modernas da Faculdade de Filosofia, Letras e Ciências Humanas da Universidade de São Paulo, como parte dos requisitos para a obtenção do título de Mestre na área de Teoria Literária e Literatura Comparada, sob a orientação do Prof. Dr. Fábio Rigatto de Souza Andrade. (versão corrigida)

"de acordo"

\section{SÃO PAULO}

2011 
Serviço de Biblioteca e Documentação da Faculdade de Filosofia, Letras e Ciências Humans da Universidade de São Paulo.

Gallo, Ligia Razera
O desequilíbrio familiar e a identidade americana nas peças de Sam Shepard / Ligia Razera Gallo; orientador Fábio Rigatto de Souza Andrade.- São Paulo, 2011.

$200 \mathrm{f}$.

Tese (Mestrado - Programa de Pós-Graduação em Teoria Literária e Literatura Comparada. Área de concentração: Teoria Literária e Literatura Comparada) - Departamento de Teoria Literária da Faculdade de Filosofia, Letras e Ciências Humanas da Universidade de São Paulo. (versão corrigida)

1. Teatro norte-americano - Século 20. 2. Identidade americana 3. Crítica teatral 


\section{FOLHA DE APROVAÇÃO}

\section{LIGIA RAZERA GALLO}

O desequilíbrio familiar e a identidade americana nas peças de Sam Shepard

Tese apresentada ao Departamento de Letras Modernas da Faculdade de Filosofia, Letras e Ciências Humanas da Universidade de São Paulo, como parte dos requisitos para a obtenção do título de Mestre na área de Literatura Comparada, sob a orientação do Prof. Dr. Fábio Rigatto de Souza Andrade.

Aprovado em:

\section{BANCA EXAMINADORA}

Assinatura:

Prof. Dr. Fábio Rigatto de Souza Andrade (DTL-USP)

Assinatura:

Assinatura:

Assinatura: 


\section{AGRADECIMENTOS}

Ao Professor Doutor Fábio Rigatto de Souza Andrade, pela orientação, pelo estímulo à leitura, pelas discussões relevantes, pela paciência que demonstrou na leitura de meus textos.

Ao Professor Dr. Jorge Mattos Brito de Almeida e à Professora Dra Mayumi Denise Senoi Ilari, pelas sugestões dadas no exame de qualificação.

Aos professores que gentilmente partilharam seu conhecimento comigo ao longo do caminho: Maria Silvia Betti, José Eduardo Vendramini, Renata Pallottini, Homero Freitas de Andrade, Ricardo Nascimento Fabbrini, Iná Camargo Costa, Cleusa Rios Pinheiro Passos.

Aos meus amigos pelo apoio constante.

Ao amigo Rodrigo Esteves de Lima Lopes, pela leitura criteriosa e atenta. Aos meus familiares pelo apoio e reconhecimento. 
O conhecimento é desperdiçado quando fica parado. O ideal é que o conhecimento e a sabedoria circulem entre as pessoas e elas possam usá-los para criar prosperidade e praticar boas ações. 
A Beny, meu marido, pela paciência.

A todos meus familiares e amigos pelo incentivo.

A minha mãe, Lúcia e meu pai, Humberto (in memoriam). 


\section{SUMÁRIO}

\section{Sam Shepard, dramaturgo: uma visão panorâmica}

1.1 Introdução.

1.2 Biografia de Sam Shepard

1.3 A Filmografia de Shepard e cronologia das peças........................................ 21

1.4 Uma Pesquisa de Literatura.................................................................... 25

1.5 Os Trabalhos de Shepard no Contexto Teatral.............................................. 26

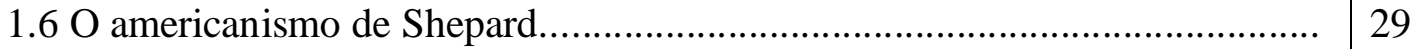

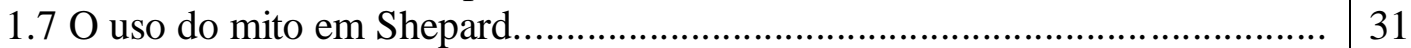

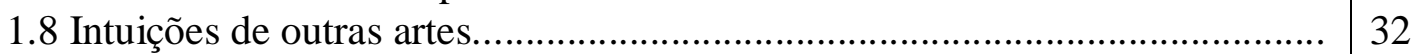

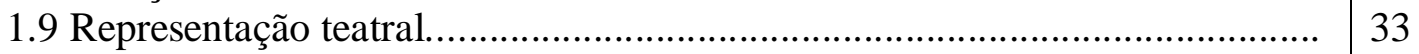

$1.10 \mathrm{O}$ uso da linguagem por Shepard.......................................................... 34

\begin{tabular}{l|l|l}
1.11 Homens e mulheres nas peças de Shepard................................................ & 35
\end{tabular}

1.12 Sam Shepard e o Super-Realismo (Hiper-Realismo)................................ 38

\section{O teatro de Sam Shepard e o drama americano moderno}

2.1 O drama familiar no teatro americano....................................................... 42

2.2 Família e Sociedade................................................................................ 44

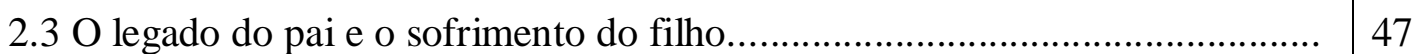

2.4 Idéias patriarcais de masculinidade.......................................................... 50

2.5 A cultura do sucesso masculino................................................................ 54

2.6 A busca do pai por autoridade e o primogênito........................................... 56

2.7 A construção da identidade americana - Shepard rein ventando a América... 61

2.8 A concepção de Shepard da identidade americana..................................... 61

2.9 A identidade americana na literatura......................................................... 66

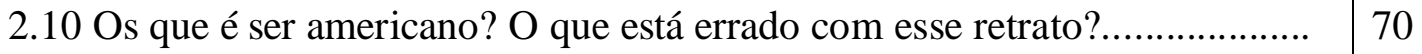

2.11 Sam Shepard e o cowboy mítico............................................................... 72

\section{A desconstrução da família americana em três peças de Sam Shepard}

\subsection{Curse of the Starving Class: o ácido de Shepard corrói a América}

3.1.1 Curse of the Starving Class- imaginando a América.................... 75

3.1.2 A centralidade de Weston........................................... 77

3.1.3 Sam Shepard e o outro drama americano................................................ 90

3.1.4 A fragmentação da linguagem em Curse of the Starving Class ................. 102

3.1.5 Curse of the Starving Class e o fracasso americano................................... 104 
3.2 Buried Child: Tabus universais: sexo (incesto), vida e morte.

3.2.1 Buried Child - a peça

3.2.2 Cenário idílico

3.2.3 Imagens visuais.

3.2.4 O Patriarca Dodge

3.2.5 A Inconsistente Halie

3.2.6 Ansel: o Herói Familiar.

3.2.7 Tilden e sua Identificação com Dodge

3.2.8 O Imaturo Bradley

3.2.9 O Papel de Vince.

3.2.10 A Criança Enterrada.

3.2.11 Reflexões sobre Curse of the Starving Class e Buried Child.

\subsection{Fool for Love: Sam Shepard e a visão masculinizada da realidade}

3.3.1 Fool For Love - paixão sadomasoquista.

3.3.2 May x a Condessa e Eddie x Martin: um relacionamento?

3.3.3 The Old Man e a determinação do masculino na peça. 


\section{RESUMO}

\section{Gallo, L. R. O desequilíbrio familiar e a identidade americana nas}

peças de Sam Shepard. 2011. 160 f. Tese (Mestrado) - Faculdade De Filosofia Ciências e Letras, Universidade de São Paulo, São Paulo, 2011.

Este estudo analisa três obras dramáticas de Sam Shepard: Curse of the Starving Class, Buried Child e Fool for Love dentro do contexto de sua obsessão compartilhada com o sonho americano sobre uma família harmoniosa mostrando um desvio do sonho o que também é predominante em peças de dramaturgos americanos, como O'Neill e Miller, que antecedem Sam Shepard. Este estudo também investiga o conceito da identidade americana nas peças.

Entre os trabalhos do dramaturgo Sam Shepard encontramos três peças que exploram o que significa ser o membro de uma família do meio oeste americano. Em Curse of the Starving Class, Buried Child, Shepard retrata a dor ecoando dentro do círculo familiar. Assim como os trabalhos iniciais de Shepard, essas peças familiares se revelam com um forte elemento biográfico, nascidas das experiências pessoais e persistentes preocupações do dramaturgo; através das peças, ele examina e reexamina o sistema familiar multigeracional do qual ele é oriundo. Por exemplo, o alcoolismo do pai e a forma como os pais são construídos em suas peças, a partir de uma perspectiva pessoal, são muito mais do que simples características das personagens, são uma condição que afeta a todos os personagens, seu relacionamento interpessoal e seus destinos. Além disso, podemos observar que o sonho americano, e sua relação com essa instabilidade familiar é um dos temas recorrentes nos dramas escritos pelo autor.

Outra intenção deste estudo é, num primeiro momento, analisar o sonho americano sob uma perspectiva histórica para definir suas múltiplas facetas desde os tempos coloniais até o século XX, tal como apresentado no drama; em segundo lugar, em um nível temático, para identificar os vários temas que Sam Shepard usa em suas peças, tais como laços familiares adulterados, alienação, incapacidade de se comunicar, a violência, a relação esposa-amante surreal, e a busca de identidade e assim definir como eles impedem a realização do 'sonho'; em terceiro lugar, as características usadas por Sam Shepard, que servem para apresentar as peças como instâncias do 'sonho' de uma família harmoniosa tornando-se um pesadelo.Na peça Fool for Love analiso também a tirania exercida pela família sobre as vidas das suas crianças crescidas. De 1977 até 1985, Shepard distancia-se da aceitação fatalística e desse modo revela mudanças tanto na perspectiva autoral como no ambiente social. Como ele faz frequentemente em seus trabalhos, Shepard reflete o comportamento de uma época.

Palavras-chave: Laços familiares rompidos. Sonho americano. Busca pela identidade. Drama. 


\begin{abstract}
Gallo, L. R. The unbalanced family and American identity in the plays

of Sam Shepard. 2011. 160 f. Tese (Mestrado) - Faculdade De Filosofia Ciências e Letras, Universidade de São Paulo, São Paulo, 2011.

This study analyzes three dramatic works of Sam Shepard: Curse of the Starving Class, Buried Child and Fool for Love within the context of their shared obsession with the American dream of a harmonious family showing a deviation of the dream which is also prevalent in plays of American playwrights such as O'Neill and Miller, preceding Sam Shepard. This study also investigates the concept of American identity in the plays.

Among the works of playwright Sam Shepard there are three plays that explore what it means to be a member of a family in the U.S. Midwest. In Curse of the Starving Class, Buried Child, Shepard portrays the pain echoing within the family. As the initial work of Shepard, these family plays reveal themselves with a strong biographical element, born of personal experience and persistent concerns of the playwright, through the plays, he examines and reviews the multigenerational family system of which he also derives from. For example, the father's alcoholism and how the fathers of his plays are constructed from a personal perspective are much more than simple features of the characters, it is a condition that affects all the characters, their relationships and their interpersonal destinations. In addition, we note that the American dream and its relationship with that family instability is one of the recurring themes in dramas written by the author.

Another aim of this study is, at first look at the American dream from a historical perspective to define its many facets from colonial times to the twentieth century, as depicted in the drama, and secondly on a thematic level to identify the various themes Sam Shepard uses in his plays, such as family tampered with, alienation, inability to communicate, violence, wife-lover surreal relationship, and the search for identity and to define how they prevent the realization of the 'dream', and finally, the features used by Sam Shepard, which serve to make the plays as instances of the 'dream' of a harmonious family becoming a nightmare. In the play Fool for Love we also analyze the tyranny exercised by the family on the lives of their grown children. From 1977 until 1985, Shepard is away from the fatalistic acceptance and thereby reveals changes in both the authorial perspective and the social environment. As he does often in his work, Shepard reflects the behavior of an era.
\end{abstract}

Keywords: Broken family ties. American Dream. Quest for identity. Drama. 


\title{
1. Sam Shepard, dramaturgo: uma visão panorâmica.
}

\subsection{Introdução}

\author{
Mas eu não estou interessado em escrever um \\ tratado sobre a família americana. \\ Isso é ridículo. \\ Sam Shepard (1984)
}

Entre os trabalhos do dramaturgo Sam Shepard existe três peças que parecem ser, senão um tratado, então certamente uma crônica da família americana. Em Curse of the Starving Class, Buried Child, Fool for Love, True West e A Lie of Mind, Shepard dramatiza a dor que reverbera dentro do círculo familiar. Estes textos, nos quais os personagens representam total ou parcialmente famílias nucleares, são referidos nesse estudo como peças familiares, sendo o propósito do mesmo analisar as três primeiras peças.

Shepard é uma figura importante no teatro americano comtenporâneo, um dramaturgo prolífico e ganhador de prêmios e, provavelmente o escritor Off-Off Broadway mais bem sucedido", de acordo com Bigsby (1985, p.221). Os prêmios ganhados por várias das mais de quarenta peças, incluindo o Prêmio Pulitzer, o New York Drama Critics' Circle Award, e onze Obies, confirman seu impacto no meio teatral. O interesse crítico muito difundido em Shepard e seu trabalho, detalhado abaixo, demonstra o desejo dos críticos e praticantes do teatro em melhor entender o artista e suas criações.

Enquanto não há um ponto universalmente aceito sobre o cânon de Shepard, existe um comum acordo que as peças discutidas aqui constituem um período definido ou fase no seu trabalho. No seu ensaio Story Itself, Christopher Brookhouse (1988, p. 65) diz:

\footnotetext{
Começando com The Curse of the Starving Class, um núcleo de personagens similares, interiores, paisagens, motivos visuais, símbolos, temas, e esquemas estruturais ocorrem e recorrem em várias combinações em cada peça de Shepard. Uma peça parece emergir de outra; os trabalhos são quase uma peça única.
}

Existe uma necessidade de examinar esse núcleo crítica e minuciosamente.

No seu resumo, escrito em 1989, sobre o lugar de Shepard no teatro americano, William Kleb diz: "O estudo detalhado sobre Shepard acabou de começar... O trabalho de Shepard precisa ser colocado mais firmemente num contexto, tanto artístico como social" (American Playwrights since 1945, 1989, p. 410). Kleb também afirma que, "Pouco trabalho crítico detalhado foi feito com o que Richard Gilman chama de " a distante rede de influências, interesses e obsessões' operando em Shepard e em suas peças" (American Playwrights since 1945, 1989, p.411). Esse estudo tenta ir ao 
encontro dessas necessidades quando leva em consideração as peças familiares, (1) examinando rapidamente o contexto artístico fornecido pelo drama familiar americano, (2) explorando atitudes americanas relacionadas ao sonho americano como um contexto social mais amplo para os trabalhos de Shepard. A família nos trabalhos de Shepard representa a mais forte das "influências, interesses, e obsessões" em ação nas suas peças familiares.

O ensaio, escrito por Charles G. Whiting (1988, p.180), Food and Drink in Shepard's Theater, apesar de representar o mais completo e detalhado estudo sobre esse assunto, discute o valor simbólico do álcool consumido: "Álcool é a contraparte das palavras relacionadas com comida nessas peças porque expressa a frustração do sonho". Enquanto as palavras usadas para descrever a garrafa de álcool são indubitavelmente importantes para as peças.

A recíproca relação entre vida e arte cria o potencial para usar as perspectivas de cada um para compreender o outro. Como Thomas Gilmore (1987, p. 8) afirma em seu estudo sobre alcoolismo na literatura do século XX:

\begin{abstract}
Apesar de eu acreditar que a literatura pode contribuir muito para uma compreensão da natureza complexa e causas do alcoolismo, e talvez ainda mais para estimular e moldar nossas respostas emocionais para o problema, eu também acredito que o domínio do conhecimento científico do alcoolismo, o qual é muito amplo e ainda em desenvolvimento, é indispensável tanto como uma base para o estudo de representações literárias da doença e como um meio de apreciar precisamente a distinta contribuição que a literatura faz.
\end{abstract}

O que é descrito em Shepard de outros pontos de vista como "inexplicável" ou "misterioso" passa a ser não somente compreensível, mas inevitável. O julgamento de Ron Mottram (1984, p. 103) de A Lie of the Mind, por exemplo, é que:

Nessa peça vemos a exaustão da alma americana produzida por uma batalha mutuamente destrutiva entre aqueles que mais deveriam amar um ao outro e ainda, por razões quase inexplicáveis, parecem pouco capazes de fazê-lo.

Dentre as muitas das diferentes características de Shepard destacam-se: o alto uso teatral de imagens, os ritmos musicais do discurso dos personagens, o humor que impregna as peças e uma tentativa de iluminar a conexão entre a real família como um sistema e sua encarnação no palco. Como qualquer outro ponto de vista específico, não pode contar a história inteira, mas pode revelar uma fonte muito importante do poder de Shepard como dramaturgo.

O critico Rodney J. Simard (1984, p. 75) comenta que: "O cânon de Shepard é altamente individualista, pré-intelectual, e intensamente subjetivo tanto na forma quanto na esfera de ação". Uma das importantes suposições feitas neste estudo, e mantidas por fontes primárias e secundárias, é que as famílias nas peças de Shepard têm fontes autobiográficas. Como o foco desse estudo é a interpretação ou explicação do texto, e não uma biografia do autor, eu vou me basear com menor intensidade na literatura existente para estabelecer uma possível conexão entre a vida de Shepard e as vidas que ele cria para seus personagens. Shepard nega ser um dramaturgo de temática intencional: "Eu nunca começo com um tema", ele escreveu para Joseph Chaikin (Chaikin and Shepard, 1994, p.117). Nas peças familiares, assim como ele fez na sua 
carreira, Shepard dramatiza suas preocupações atuais. Gerald Weales (em MARRANCA, 1981, p. 38) escreve que: "O crítico com uma predileção por ficção como biografia... poderia usar as peças peculiares de Shepard como um tipo de mapa disfarçado [da própria vida dele]".

De forma a alcançar os objetivos deste estudo, ele será organizado da seguinte forma: (1) revisando literatura biográfica e crítica sobre Shepard e suas peças, (2) pesquisarei brevemente o drama familiar como uma forma dominante no teatro americano, (3) delineando mudanças históricas nas atitudes americanas com relação ao sonho americano. Analisarei Curse of the Starving Class e Buried Child como exemplos de famílias nucleares. Fool for Love, lida com irmãos adultos, que não vivem mais com seus pais. Abordarei a identidade americana do ponto de vista que Shepard utiliza em seu trabalho. Finalmente, incluirei as conclusões alcançadas no presente estudo.

\subsection{Biografia de Shepard}

Sam Shepard nasceu em Fort Sheridan, Illinois, no dia cinco de novembro, 1943, batizado como Samuel Shepard Rogers III. Seu pai, Samuel Shepard Rogers II, era um aviador do exército e como consequência estava frequentemente ausente, deixando Steve, como o jovem Shepard era chamado, com sua mãe, Jane Schook Rogers e suas duas irmãs mais novas, Roxane e Sandy. A família mudava-se frequentemente de estado para estado, de uma base do exército para outra, até que Rogers II aposentou-se do exército para retomar sua educação interrompida e seus laços familiares. A família fixou-se na Califórnia, primeiramente em Pasadena e então num rancho de abacates próximo a Duarte.

A adolescência do jovem Shepard foi, em muitas maneiras, como a de seus contemporâneos: ele criou um carneiro que recebeu prêmios e até pensou em tornar-se veterinário; numa competição de rodeio do colegial, ele fez parte de uma equipe de laço vencedora. O lar dos Shepards era instável e frequentemente violento: "Eu fui criado com isso; fui criado violentamente. Então isso tem sido parte da minha vida" (SESSUMS, 1988, p. 76). Até mesmo depois que Rogers II aposentou-se do exército e a família toda estava junta, distâncias intransponíveis separavam pai e filho. Em "uma entrevista de 1988 Shepard denominou seu relacionamento com o pai como "misterioso": "É um relacionamento de absoluto desconhecimento. Eu nunca o conheci apesar de ele estar por perto o tempo todo." (SESSUMS, 1988, p. 75)

Como descrito por entrevistadores e biógrafos, Rogers II era "um bêbado letal", "um alcoólatra com propensão para violência" (SESSUMS, 1988, p. 71), o tipo de pai que aparece frequentemente nas peças de Shepard. Rogers II deixou para seu filho alguns legados além de bebedeira e brigas como o próprio Shepard afirma (SESSUMS, 1988, p. 77):

Vou ser eternamente grato a ele por ter me apresentado a Garcia Lorca quando eu era criança em espanhol. Ele falava espanhol fluentemente. O que é pouco comum. Ele me disse tudo sobre a vida de Garcia Lorca com os ciganos e tudo mais. Aquilo me fez ficar fascinado por poesia ainda bem jovem. Ele também adorava o jazz de New Orleans. Então eu cresci lendo Garcia Lorca e ouvindo jazz. 
Os legados discrepantes - sem raízes e violência, poesia e jazz - simbolizam tanto condições como tópicos nas peças de Shepard. Eventos biográficos e condições tais como o frequente pai ausente, a família desconectada, o oeste americano, como são e como foram mitificados, são constantes preocupações do dramaturgo. Shepard descreve a atmosfera do início da sua vida em seus trabalhos Hawk Moon (SHEPARD, 1973) e Motel Chronicles (SHEPARD, 1982). Sua mãe, que se tornou uma professora quando a família estabeleceu-se, é mencionada frequentemente nesses trabalhos, mas não está obsessivamente presente nas peças como estão as várias versões do pai de Shepard. Shepard a descreve como "uma mulher forte e sólida como uma rocha" (KROLL, "Tall, Dark Stranger”, 1985, p. 70). Em Motel Chronicles (SHEPARD, 1982, p. 17) ele a descreve carregando uma arma para protegê-los em Guam e "colocando-o para dormir em banheiras por todo o estado de Idaho".

Aos dezenove anos Steve Rogers escapou do rancho de abacates ao unir-se ao Bishop's Repertory Players, uma companhia de atores itinerante com base na cidade de Nova Yorque. O rompimento com sua família foi significativo e foi sinalizado pela sua troca de nome, Steve Rogers, Californiano, tornou-se Sam Shepard, ajudante de garçom em Nova Yorque e cowboy urbano. "'Havia essa luta intensa com meu pai', diz Shepard, 'e naquele momento eu escapei. E eu pensei, acho que eu vou ter que começar tudo de novo, fingir que nem uma família eu tenho'. "(KROLL, 1985, p. 70). Mas em 1984 ele disse na Califórnia, "Eu simplesmente sinto que nunca vou superar o fato de ser daqui" (LIPPMAN, 1984, p. 10). Durante a sua carreira, suas peças descrevem um círculo distante do seu lar californiano e depois se voltam para ele.

Charles Mingus era o colega de quarto de Shepard na cidade, um amigo do colegial com conexões num clube de jazz Village Gate onde Shepard trabalhou como ajudante de garçom. A atmosfera em Nova Yorque era notadamente diferente da Califórnia. "Naquela época", Shepard disse para Kenneth Chubb (1974, p. 189), "a geração beat foi uma grande influência... Nós conversávamos sobre Ferlinghetti e Corso e Kerouac e todos aqueles caras, e jazz...”. O garçom chefe do Village Gate, Ralph Cook, estava procurando peças para serem encenadas no recém fundado Teatro Gênesis. Shepard escreveu para ele duas peças de um ato em 1964, The Rock Garden (SHEPARD, 1964) sobre a qual Shepard diz, "tratava-se da época em que saí da casa dos meus pais", e Cowboys (SHEPARD, 1964), uma peça inspirada em Mingus e Shepard, "brincando de cowboys em Nova York" (CHUBB, 1974, p. 190).

A dramaturgia de Shepard deve muito pouco à tradição teatral americana; ele nem lia peças nem ia ao teatro. Apesar de conhecer Samuel Beckett, e ter lido Waiting for Godot (CHUBB, 1974, p. 191), sua familiaridade com o trabalho de outros dramaturgos iniciou-se após o começo de sua própria carreira: "Comecei a ler alguns autores depois que comecei a escrever minhas peças. Brecht, Eugene O'Neill” (SESSUMS, p. 78). Ao invés de unir-se a essa corrente principal e tão bem sucedida, Shepard preferiu o teatro alternativo Off-Off Broadway.

O sucesso inicial de Shepard está relacionado a Michael Smith, que trabalhava como crítico para o Village Voice, e que escreveu comentários positivos sobre as duas primeiras peças de Shepard e continuou a escrever favoravelmente sobre o trabalho de Shepard. O interesse de Smith foi suficiente para que ele dirigisse a estréia de Icaru's Mother no Café Cino (SHEPARD, 1965). Em 1966 aquela peça, juntamente com Chigago e Red Cross, trouxe para Shepard os três primeiros dos seus onze Obies; Smith 
não era mais o único admirador de Shepard. Somando-se a isso, as críticas de Smith delineavam a "abordagem antiinterpretativa, antinaturalista do teatro de Shepard que se tornou central a sua subsequente recepção e aceitação critica" de acordo com William Kleb (KLEB, 1989, p. 391). Essa abordagem e suas ramificações são discutidas abaixo.

Shepard escreveu suas peças iniciais rapidamente, recusando-se a reconsiderá-las ou revisá-las uma vez que elas estavam escritas. Dessa perspectiva de 1980, ele disse:

\begin{abstract}
Havia tanto para ser escrito, que eu sentia que não podia gastar tempo reescrevendo; tinha que seguir em frente com o próximo trabalho. Era um tipo furioso de escrita. Obsessivo. Eu me identificava muito com o jazz naquela época - não havia razão para que minha escrita não fosse exatamente como uma improvisação de jazz. Eu imaginava que voltar e mudá-la seria uma inverdade aos impulsos que faziam com que ela acontecesse. (ANSEN, 1980, p. 118)
\end{abstract}

Impulsividade e improvisação são traços frequentes nas peças iniciais bastante influenciadas pelas drogas e a contra cultura. $\mathrm{O}$ homem que as escreveu é descrito por Kevin Sessums como "aquela pessoa louca, brava e viciada em drogas" que, Shepard explica, "era um produto daquela época" (ANSEN, 1980, p. 78).

As peças iniciais são curtas, não realistas ou anti - realistas; personagem, cenário e tempo são altamente mutáveis. As imagens e ícones invocados nelas provêm da cultura popular americana o que inclui o cinema, a televisão e a música popular. Tematicamente são unificadas por uma frequente e frenética busca por uma identidade que é intensificada pelo parecer não substancial do mundo criado pelas peças. Os protagonistas são homens e a maioria dos personagens é jovem. É um mundo de relacionamentos temporários tão fluido quanto os personagens. Esses personagens frequentemente tentam descobrir identidades autênticas ao desempenhar papéis que representam seus possíveis egos. Ao invés de buscar a identidade através da introspecção ou revendo suas histórias pessoais, eles experimentam possíveis personalidades. Como Phyllis Randall menciona: "Nas peças iniciais, os personagens frequentemente adotam várias vozes para encontrar a sua própria, para descobrir que eles são parecidos com um ator trabalhando o seu papel...” (KING, 1988, p. 122).

As peças do final dos anos sessenta estabelecem Shepard como uma presença marcante no teatro Off-Off Broadway. La Turista (SHEPARD, 1967), a primeira peça longa de Shepard, foi encenada no American Place Theater em 1967. Apesar de Shepard exercer sua opção de excluir os críticos, Elizabeth Hardwick assistiu e escreveu sobre a estreia. La Turista e Forensic \& the Navigators (SHEPARD, 1967) também produzidas em 1967, ganharam Obies. Sua crítica ponderada adicionou outro fio à meada da interpretação de Shepard ao comparar os efeitos da peça de Shepard à poesia:

Tom e estilo mantêm o trabalho coeso, criam qualquer efeito emocional que teremos. Os personagens e conflitos são feitos dos episódios e imagens, mas eles são de um tipo complexo e indistinto. (MARRANCA, 1981, p. 70)

Apesar dos teatros Off-off-Broadway serem incapazes de dar suporte financeiro aos seus dramaturgos, em 1967 Shepard recebeu suporte institucional. Fundos da Universidade de Minnesota, Yale, e da Fundação Rockefeller, o que possibilitou que ele parasse de trabalhar como garçom e se concentrasse em escrever. Contribuições financeiras da Fundação Guggenheim, em 1968, permitiram que ele continuasse seu 
trabalho. A peça de um ato Melodrama Play (SHEPARD, 1968), o primeiro trabalho de Shepard que incorporou músicas de rock de sua própria autoria, e pela qual ganhou um outro Obie. Um grande interesse e respeito pelo trabalho de Shepard movia-se para além da Off-Broadway; sua peça Operation Sidewinder (SHEPARD, 1970) inaugurou temporada no Lincoln Center em 1970 após uma tentativa malograda de produzí-la em Yale.

Enquanto sua fama e reputação entre os críticos aumentavam, sua vida pessoal deteriorava-se. As coisas em Nova York "ficavam cada vez mais insanas", ele disse:

...você estava fazendo essa coisa chamada teatro nesses pequenos lugares e
você trazia a sua experiência para esse círculo, e depois voltava e vivia
esse tipo de vida apertada, insular, de modo protetor, onde você tentava
defender a si mesmo. E eu também estava envolvido com muitas drogas
então - tornou-se muito difícil você sabe, tudo parecia despedaçar-se.
(CHUBB, 1974, p. 200)

Apesar do seu casamento, em 1969, com a atriz O-Lan Johnson que trabalhava no Teatro Gênesis e do nascimento do seu filho Jesse, ele envolveu-se romanticamente com a cantora de rock Patti Smith. Cowboy Mouth (SHEPARD, 1971), peça que eles escreveram juntos, é um relato disfarçado do caso de amor que eles tiveram que se tornou enfaticamente biográfico quando Shepard e Smith encenaram a peça no American Place Theatre em 1971.

Após a produção de Cowboy Mouth, Mad Dog Blues no Teatro Gênesis, e Back Bog Beast Bait, Shepard mudou-se para Londres com sua esposa e filho naquele mesmo ano. Sua mudança para Londres de certa maneira representou uma fuga da insanidade da sua vida em Nova York. Shepard também tinha "essa fantasia que eu viria para cá e de alguma maneira iria me inserir numa banda de rock ' $n$ roll' (CHUBB, 1974, p. 200). A banda nunca se materializou, mas a carreira teatral de Shepard floresceu.

Durante seus anos em Londres, Shepard escreveu The Tooth of Crime (SHEPARD, 1972), Action (SHEPARD, 1974), e Geography of a Horse Dreamer (SHEPARD, 1974). Charles Marowitz dirigiu a primeira produção de Tooth of Crime (SHEPARD, 1972) no London's Open Space em 1972. Nem a versão de Marowitz nem a versão do Performance Group em 1973 agradou Shepard. Como Kleb (1983, p. 394) comenta: “o desconfortável relacionamento de Shepard com diretores é um tema subtextual importante em toda a história de representação do seu trabalho, e claramente o assunto atingiu o clímax com as versões de Marowitz e Schechner de Tooth of Crime”. Como consequência, Shepard decidiu ele mesmo dirigir Geography of a Horse Dreamer (SHEPARD, 1974) quando foi produzida no Royal Court.

As peças Londrinas marcam uma mudança na dramaturgia de Shepard comentada por vários críticos. Essas peças examinam a natureza da criatividade e a posição do artista em relação à sociedade e a ele mesmo. Elas são conscientemente escritas com mais habilidade do que as peças dos anos 60. Nas suas próprias palavras, Shepard estava "aventurando-se" (CHUBB, 1974, p. 199). Em 1972, ele descreve seu trabalho inicial numa carta para Joseph Chaikin: "Eu compreendi que tudo que eu havia feito até agora estava meio que adormecido. Toda minha escrita parece ter o mesmo valor que qualquer produto de qualquer pessoa adormecida". (CHAIKIN e SHEPARD, 1994, p. 7) 
Shepard atribui parte do seu progresso na escrita a sua interação com atores. Anos observando-os e a experiência de dirigi-los estimulou Shepard a considerar, "o que significa para um ator na verdade encontrar essa tarefa de fazer isso no palco" (CHUBB, 1974, p. 195). Num artigo publicado em 1977, ele escreveu:

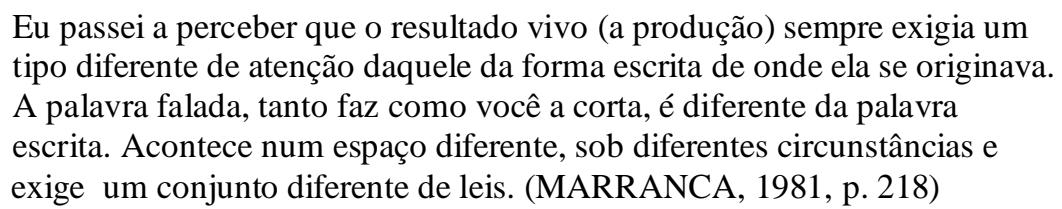

Shepard sempre achou que ser da América, ao invés de estar nela, era uma experiência iluminadora. Na entrevista concedida a Kenneth Chubb (1974, p. 198) e conduzida em Londres, ele disse:

Eu realmente descobri o que é ser um americano somente após ter vindo para Inglaterra. Nada faz sentido quando você está lá, mas o mais distante que você está de lá, mais as implicações com as quais você cresceu começam a emergir.

Duas das peças escritas na Inglaterra, The Tooth of Crime (1972) e Action (1975), foram agraciadas com prêmios Obie durante a ausência de Shepard.

Shepard e sua família retornaram para os Estados Unidos em 1974, e alugaram um rancho perto de São Francisco. O Magic Theatre de São Francisco começou a produzir o trabalho de Shepard em 1970 com La Turista, mas com o retorno do dramaturgo para Califórnia e a mudança do teatro de Berkeley para São Francisco, uma genuína colaboração iniciou-se. O diretor artístico John Lion afirma: "Nosso plano original era que - Sam, Michael MacClure e eu - traríamos projetos para o teatro e os executaríamos". O primeiro dos projetos foi a produção de Action (SHEPARD,1975) e Killer's Head sob a direção de Shepard. De 1974 até 1983, o Magic Theatre produziu quatorze peças de Shepard, várias delas dirigidas pelo dramaturgo.

Bob Dylan convidou Shepard para acompanhar o Rolling Thunder Revue em 1975. Apesar de Shepard ser baterista e ter formado The Holy Modal Rounders, sua função com $o$ Rolling Thunder era narrar mais do que tocar. O filme sobre a turnê nunca aconteceu, mas a reação de Shepard em relação a Dylan e essa experiência estão detalhadas no Rolling Thunder Logbook (SHEPARD, 1977), um diário que ele manteve durante a turnê. A preocupação contínua de Shepard com as imensas recompensas e concomitantes custos do status de um superstar pode muito bem se relacionar com a experiência de Dylan assim como a do próprio Shepard.

The Sad Lamento of Pecos Bill on the Eve of Killing His Wife (SHEPARD, 1976), foi uma partida para Shepard - uma ópera de um ato criada para o Bay Area Playwright's Festival. Enquanto essa forma musical em particular era incomum para Shepard, apesar de outras formas de musicalidade sempre serem uma constante no seu trabalho. "Eu acho que todas elas são musicais", ele comentou sobre suas peças em 1984. "Eu gosto de olhar para a língua e os ritmos profundos da peça, e tudo aquilo para mim está relacionado à música diretamente" (LIPPMAN, 1984, p. 13). Shepard usou analogias musicais para descrever as confrontações de seus personagens e seu próprio âmbito como ator, mas são as conexões emocionais forjadas pela música que mais o 
interessam: "imediatamente faz com que os expectadores comunguem com a realidade emocional. Porque nada comunica emoções melhor que a música, nem mesmo a melhor peça teatral do mundo" (CHUBB, 1974, p. 57). Em 1979, ele assinou o libreto para o musical Jacaranda de Daniel Nagrin (1979).

O Magic Theatre produziu Angel City (SHEPARD, 1976). É uma acusação de Shepard sobre uma Hollywood voraz onde magnatas reptilianos devoram a criatividade, uma peça que expressa artisticamente mais ironia que o subsequente início da carreira de Shepard como ator de cinema em Days of Heaven (1978). Suicide in B Flat (SHEPARD, 1976), produzida em Yale Repertory em 1976 e em Londres em 1977, dramatiza os efeitos limitadores da imagem pública do artista. O suicídio do título é a única escapatória da pessoa pública para um artista como salvador. Shepard dirigiu Angel City no Magic Theatre e colaborou com Suicide in B Flat (1979), a qual deu destaque a uma improvisação do pianista de jazz Harry Mann. Ambas as peças continuam a expandir os temas londrinos: a vulnerabilidade da criatividade, isolação artística, e as alegrias e custos do reconhecimento. Essas peças também continuam a exibir algumas das marcas de qualidade do início da carreira de Shepard: a busca por identidade, os mitos e ícones da América infundidos no trabalho através de imagens e ritmos da cultura popular.

A celebridade de um tipo diferente é também o assunto de Seduced (SHEPARD, 1978), encenada primeiramente pelo Trinity Square Repertory em Providence, Rhode Island. Harry Hackmore, um personagem moldado em Howard Hughes, primeiro é seduzido pelo poder e então pela imagem do seu próprio mistério e invencibilidade.

A estreia londrina de Curse of the Starving Class em 1977 e a americana no New York Shakespeare Festival no ano seguinte receberam resposta crítica diversificada. A produção londrina trouxe para Shepard um Obie pela peça, a primeira vez que o prêmio foi concedido a uma peça que ainda não havia sido produzida nos Estados Unidos. Numa crítica sobre a produção do Royal Court, entretanto, Thomas P. Adler (1987, p. 409) chamou-a de "uma peça antiquada e evidentemente autobiográfica sobre problemas familiares" e a julgou "tão banal em seu esboço que nos faz imaginar se esse gênero por tanto tempo tão favorito já não teria cumprido o seu papel”.

Com Curse of the Starving Class (SHEPARD, 1978) decisivamente mudou sua busca por lugar e identidade dentro do círculo familiar; seus personagens voltaram para o lar. Sua próxima peça sobre família foi Buried Child (SHEPARD, 1978) a qual estreou no Magic Theatre em sete de julho de 1978. Duas produções na costa leste a seguiram: no Theatre de Lys em outubro e em Yale Repertory Theatre três meses mais tarde. Em 17 de abril de 1979, Buried Child conquistou o Prêmio Pulitzer. Os críticos Off-Broadway adicionaram um Obie mais tarde naquele ano. Dois anos mais tarde, escrevendo sobre teatro experimental americano, o dramaturgo resumiu a resposta da crítica:

Falando de modo geral, as atitudes da imprensa ainda são as mesmas que elas sempre foram em relação a novos trabalhos. Condescendência embrutecida ou completa indignação. O principal tema da imprensa ao avaliar o meu trabalho tem sido "Isso é bom se você gosta desse tipo de coisa e ele certamente tem jeito com as palavras mas quando ele vai parar de brincar e nos dar UMA NOVA PEÇA AMERICANA DE GRANDE VULTO. (MARRANCA, 1981, p. 213) 
Aparentemente, Buried Child teria sido essa peça.

Curse of the Starving Class e Buried Child, contudo, o trouxeram mais para perto da elite teatral. As superfícies incrivelmente realistas, unidas a agonia familiar das peças, incitaram comparações com Eugene O’Neill. Em American Playwrights, Bonnie Marranca (1981, p. 107) escreve sobre Shepard:

\begin{abstract}
A questão sobre raízes - e o seu oposto, deslocamento - tem um lugar de destaque no seu trabalho dramático. Mas desta vez o questionamento vai mais fundo do que raízes imediatas mais para a área específica do destino e hereditariedade. Nesse respeito Shepard está firmemente no território dramático de Eugene O’Neill.
\end{abstract}

Dois trabalhos muito diferentes de Shepard, ambos colaborações com Joseph Chaikin, apareceram em 1978 e 1979. Mas ainda não são consideradas peças teatrais, Tongues (SHEPARD, 1978) e Savage Love (SHEPARD, 1979), que envolviam percussão e voz; e percussão, voz, e piano respectivamente. Shepard interpretou um percussionista na versão original de Tongues no Magic Theatre assim como ele também o fez em Drum War, uma espécie de evento teatral em que ele tomou parte em março de 1980.

Shepard voltou-se para suas preocupações com assuntos familiares em True West (SHEPARD, 1980). A premiere de São Francisco agradou a companhia e aos críticos, mas quando o diretor do Magic Theatre, Robert Woodruff, começou a trabalhar na produção para o New York Shakespeare Festival, discórdias com Joseph Papp aumentaram, culminando com a saída de Woodruff fazendo com que Shepard repudiasse a produção. Todavia a peça entrou em cartaz em Nova York em dezembro de 1980. Quando True West (SHEPARD, 1980) reestreou no Magic Theatre na primavera seguinte, a resposta foi desapontadora. Em 1982, entretanto, a Chicago's Steppenwolf Company levou sua bem sucedida versão para Nova Yorque onde emplacou uma longa temporada. Malkovitch interpretou Lee e Gary Sinise, que também dirigiu, interpretou Austin.

Fool for Love (SHEPARD, 1983), a próxima peça de Shepard no Magic, teve um grande sucesso em São Francisco e a produção completa foi para Nova Yorque. Apesar da resposta crítica não ter sido positiva, a peça teve 1000 apresentações e ganhou dois Obies para Shepard (como dramaturgo e diretor). Fool for Love (SHEPARD, 1983) continuou o foco na família, dramatizando um relacionamento torturante entre amantes que são filhos do mesmo The Old Man - "um personagem que só existe nas mentes de May e Eddie”, mas que está presente no palco.

Seguindo a produção de Fool for Love, Shepard deixa sua esposa e filho e muda-se com Jessica Lange para Santa Fé, Novo México. Ele e Jéssica Lange encontraram-se enquanto filmavam Frances (1983) sendo que seu relacionamento entra em conflito com o casamento dele o que contribuiu para Fool for Love. Em Janeiro de 1983 ele escreveu para Joseph Chaikin:

Estou na terceira semana de ensaios aqui no Magic Theater para minha nova peça chamada Fool for Love, a qual realmente é uma consequência de todo esse sentimento tumultuoso pelo qual eu passei no último ano. É uma peça muito emocional e em alguns aspectos é embaraçoso para eu testemunhar, mas ao mesmo tempo é necessário. (CHAIKIN e SHEPARD, 1994, p. 117). 
Em A Lie of the Mind Shepard continua a explorar sua vida pessoal. Samuel Shepard Rogers II morreu em 1983, atropelado por um carro próximo da sua casa em Santa Fé, Novo México. Shepard transforma a morte de seu pai e o funeral militar numa peça, criando uma nova versão da sua relação com seu pai. A intensificação do seu relacionamento com Jessica Lange também influenciou a sua preocupação na peça com os relacionamentos masculino/feminino e as famílias criadas e conectadas por eles.

A Lie of the Mind foi encenada em Nova Yorque em cinco de dezembro de 1985, no Promenade Theater sob a direção do próprio Shepard. O elenco incluía vários atores famosos: Harvey Kietel, Amanda Plummer, Geraldine Page e Aidan Quinn. A peça foi bem recebida pelos principais críticos da época, Willian Kleb, escreveu, "No lugar do Village Voice (é um jornal semanal livre de Nova Yorque que publica artigos sobre arte, teatro, atualidades), o New York Times passou a ser o principal defensor jornalístico de Shepard no momento" (MARRANCA, 1981, p. 400). A Lie of the Mind ganhou o Drama Critics Circle Award como melhor peça em 1986.

\subsection{A Filmografia de Shepard e cronologia das peças}

A carreira de Shepard em filmes aumentou exponencialmente seu status de celebridade ao mesmo tempo que proporcionou a ele uma segurança econômica que ele não tinha anteriormente, seja como um escritor Off-Broadway ou como dramaturgo regional. Essa carreira também afetou a análise crítica das suas peças. Kleb menciona que a mitologia havia sido uma preocupação tanto de dramaturgos quanto de críticos, “... mas agora, com a triunfante aparição de Shepard como um lacônico texano no filme Days in Heaven (1978), acabou frequentemente tornando-se uma premissa da qual seu trabalho era visto e avaliado" (MARRANCA, 1981, p. 397). A interpretação de Shepard de Chuck Yeager em The Right Stuff (1983), pela qual ele recebeu uma nomeação para um Academy Award, também contribuiu para formar sua mítica imagem americana.

\section{Peças escritas por Shepard:}

- 1964 Cowboys

- 1964 The Rock Garden

- 1965 Chicago

- 1965 Icarus's Mother

- 1965 4-H Club

- 1966 Red Cross

- 1967 La Turista

- 1967 Cowboys \#2

- 1967 Forensic \& the Navigators

- 1969 The Unseen Hand

- 1969 Oh! Calcutta! (contributed sketches)

- 1970 The Holy Ghostly

- 1970
- 1971 Mad Dog Blues

- 1971 Back Bog Beast Bait

- 1971 Cowboy Mouth (with Patti Smith)

- 1972 The Tooth of Crime

- 1974 Geography of a Horse Dreamer

- 1975 Action

- 1976 Suicide in B Flat

- 1976 Angel City

- 1977 Inacoma

- 1978 Buried Child

- 1978 Curse of the Starving Class

- 1978 Tongues (with
- 1981 Savage Love (with Joseph Chaikin)

- 1983 Fool for Love

- 1985 A Lie of the Mind

- 1987 A Short Life of Trouble

- 1991 States of Shock

- 1993 Simpatico

- 1994 Safe Passage

- 1998 Eyes for Consuela

- 2000 The Late Henry Moss

- 2004 The God of Hell

- 2007 Kicking a Dead Horse 
Sidewinder

Joseph Chaikin)

- 1980 True West
- 2009 Ages of the

Moon

\section{Livros (coletâneas)}

- Hawk Moon, PAJ Books, 1973, ISBN 0-933826-23-0

- $\quad$ Motel Chronicles, City Lights, 1983, ISBN 0-87286-143-0

- Seven Plays, Dial Press, 1984, 368 pages, ISBN 0-553-34611-3

- Fool For Love and Other Plays, Bantam, 1984, 320 pages, ISBN 0-553-34590-7

- The Unseen Hand: and Other Plays, Vintage, 1996, 400 pages, ISBN 0-67976789-4

- $\quad$ Cruising Paradise, Vintage, 1997, 255 pages, ISBN 0-679-74217-4

- Great Dream Of Heaven Vintage, 2003, 160 pages, ISBN 0-375-70452-3

- Rolling Thunder Logbook, Da Capo, 2004 reissue, 176 pages, ISBN 0-30681371-8

- Day out of Days: Stories, Knopf, 2010, 304 pages, ISBN 978-0-307-26540-1

\section{Filmografia}

Ator

- 1963 Apples In the Tree

- 1965 Rusakai

- 1970 Brand X

- 1978 Renaldo and Clara - Rodeo

- 1978 Days of Heaven - The Farmer

- 1980 Resurrection - Cal Carpenter

- 1981 Raggedy Man - Bailey

- 1982 Frances - Harry York

- 1983 The Right Stuff - Chuck Yeager

- 1984 Paris, Texas - unconfirmed

- 1984 Country - Gil Ivy

- 1986 Crimes of the Heart - Doc Porter

- 1987 Baby Boom - Dr. Jeff Cooper

- 1989 Steel Magnolias - Spud Jones

- 1990 Bright Angel - Jack

- 1991 The Voyager - Walter Faber

- 1992 Thunderheart - Frank Coutelle

- 1993 The Pelican Brief - Professor Thomas Callahan

- 1994 Safe Passage (film) - Patrick Singer

- 1995 Streets of Laredo (film)- Pea Eye Parker

- 1999 Snow Falling on Cedars Arthur Chambers

- 1999 Purgatory - Sheriff
- 2000 Hamlet - The Ghost

- 2000 All the Pretty Horses - J.C. Franklin

- 2001 Black Hawk Down - Maj. Gen. William F. Garrison

- 2001 Kurosawa - Narrator

- 2001 Shot in the Heart - Frank Gilmore

- 2001 Swordfish - Senator James Reisman

- 2001 The Pledge - Eric Pollack

- 2003 Blind Horizon - Sheriff Jack Kolb

- 2004 The Notebook - Frank Calhoun

- 2005 Don't Come Knocking Howard

- 2005 Bandidas - Bill Buck

- 2005 Stealth - Capt. George Cummings

- 2006 Walker Payne - Syrus

- 2006 The Return - Ed Mills

- 2006 Charlotte's Web (Narrator)

- 2007 Ruffian - Frank Whiteley

- 2007 The Assassination of Jesse James by the Coward Robert Ford Frank James

- 2008 The Accidental Husband Wilder 
Apesar dos muitos filmes em que ele atuou, ele menciona: "Eu realmente não me considero um ator. Nos filmes você pode escapar de um monte de situações que você não consegue escapar no palco. Acredito que praticamente qualquer um pode atuar num filme" (LIPPMAN, 1984, p. 13).

\section{Roteirista}

- 1968 Me and My Brother, dir: Robert Frank

- 1970 Zabriskie Point, dir: Michelangelo Antonioni

- 1984 Paris, Texas, dir: Wim Wenders

- 1985 Fool for Love, dir: Robert Altman

- 2005 Don't Come Knocking, dir: Wim Wenders

\section{Diretor}

- 1988 Far North (também o roteirista)

- 1994 Silent Tongue (também o roteirista)

A primeira aparição de Shepard como ator de cinema não foi sua primeira conexão com o meio. Ele foi co-autor do roteiro de Zabriski Point de Antonioni em 1968 e durante os anos 70 escreveu outros roteiros que não foram produzidos. Em Paris, Texas, Shepard colaborou com o diretor alemão Wim Wenders, o roteiro ganhou a Palma de Ouro em 1984 no Festival de Filmes de Cannes. Em 1985, Shepard relutantemente concordou em atuar numa versão cinematográfica de Fool for Love, mas o relacionamento com o diretor foi ruim. Shepard declarou:

Eu gostei do que o Robert Altman fez até certo ponto. E eu me enganei ao pensar que ele teria integridade ao fazer o que se propôs. Ele mostrou que era muito habilidoso no que fazia. Aquilo me surpreendeu. Eu senti que ele fez tudo com muita energia e força, porém ele não deu tudo de si como me disse que iria fazer. (SESSUMS, 1988, p. 78).

A resposta de Shepard para sua percepção da má direção de seu roteiro duplicou sua resposta teatral: ele mesmo dirigiu seu próximo roteiro. Far North (SHEPARD, 1988), o primeiro filme de Shepard como escritor e diretor não foi bem recebido nem comercialmente, nem pela crítica. Shepard não estava somente experimentando num novo meio como diretor, mas também tentava escrever de um novo ponto de vista: "explorando o lado feminino da vida". Assim como Paris, Texas; Far North partilha as mesmas preocupações de suas peças com situações familiares, personagens, e imagens, e novamente demonstra uma forte conexão com sua vida pessoal. Ele declarou sobre o filme: "Estou começando a perceber que o lado feminino sabe muito mais que o lado masculino. Sobre nascimento. Sobre morte". (SESSUMS, p. 73). Shepard atribuiu essas reflexões ao seu relacionamento com Lange, ao qual ele se refere como "sua salvação". 
"É como uma revelação... é como descobrir uma completa nova vida que você não sabia que tinha dentro de você... E nesse caso está relacionado com amor e a possibilidade de uma família real" (KROLL, Who's that Tall, Dark Stranger, 1985, p. 73). A família de Shepard e Lange inclui um filho e filha dos dois.

O progresso da vida de Shepard está ligado tanto à forma quanto ao conteúdo de suas peças. Ele declara:

Acredito que o ambiente em que vivo tem uma significante importância na minha escrita durante a maior parte do tempo, mais do que eu estou consciente disso... É como se as peças fossem um tipo de crônica que eu estivesse escrevendo sobre a minha pessoa. (MARRANCA, 1981, p. 219).

Sua ascenção na mídia como celebridade fez dele parte da cultura popular americana, a mesma cultura que ele explora como dramaturgo em suas peças. David Ansen (1980, p. 118) observa que a descrição de Bob Dylan feita por Shepard é tão apropriada para o autor quanto para quem ele escreve. Shepard escreveu que, "Dylan cria uma atmosfera mítica sobre tudo que está a nossa volta. A terra onde caminhamos todos os dias e nunca vemos até que alguém nos mostre". De todas as comparações feitas entre Shepard e outros artistas, essa é a mais reveladora. Outra é a comparação com Elvis Presley. John Lion escreve:

Elvis Presley e Sam Shepard significam uma mudança na estrutura da sociedade americana que corta muito mais profundamente do que frases críticas como "o nascimento do rock and roll" ou a "morte do oeste americano". Para ambos, Presley e Shepard, está gravada a idéia do "selvagem nobre". Ambos aparentemente vêm de nenhum lugar, alcançaram o topo de suas profissões sem nenhum treinamento formal, rapidamente tornaram-se a matéria prima do mito popular. (Rock ' $n$ Roll Jesus with a Cowboy Mouth, 1984, p. 7)

A imagem de Shepard, assim como a de Elvis Presley, é parcialmente autogerada. A reivindicação do dramaturgo sobre sua ingenuidade não tutorada repousa em parte nas respostas como as que ele deu para pergunta de Amy Lippman, "Que escritores o influenciaram? Que dramaturgos?" "Eu não sei. Qual o objetivo?", respondeu Shepard (Rhythm and Truths: An Interview with Sam Shepard, 1984, p. 12).

Elvis Presley e Bob Dylan não somente compuseram as vidas das suas gerações com sua música, mas também a exemplificaram em suas vidas, atingindo durante o processo uma estatura mítica e um valor de ícone para os seus contemporâneos. O progresso da maturação psicológica e social de Shepard está claramente mapeado não somente pelo aumento da sua habilidade e seu esforço e atenção como dramaturgo, mas também pela progressão de temas tratados e ponto de vista autoral. Ele é um tipo de barômetro do seu tempo e da sua geração. Richard Gilman, na sua introdução de Seven Plays (SHEPARD, 1981, p. xii) diz: "Se existe um exemplar mais perfeito de uma educação cultural adquirida (absorvida) nos anos cinquenta do que a de Shepard, eu não consigo imaginar quem poderia ser". C. W. E. Bigsby (1985, p. 221) declara: "[Shepard] tem o desejo dos anos sessenta de fazer com que fragmentos sejam coerentes e a crença dos anos setenta de que a verdade pode essencialmente estar naqueles fragmentos". John Lion (1984, p. 8) afirma que: "A base do seu discurso muda continuamente e é sempre provocativo; o que faz de Shepard, ao menos em termos de personalidade, o borrão de tinta dos anos oitenta". Shepard, um produto dos anos cinquenta, o caçador dos anos 
sessenta, o crente dos anos setenta e o borrão de tinta dos anos oitenta, afirma sobre a sua escrita: "Essas coisas todas estão no ar ao nosso redor e tudo que estou tentando fazer é agarrar-me a elas" (LIPPMAN, 1984, p. 11). Os mais convincentes críticos do trabalho de Shepard são aqueles que tratam o trabalho de Shepard como "um único ato contínuo de imaginação" nas palavras de Richard Gilman, uma resposta imediata para uma experiência imediata contra uma base social e política volátil.

Shepard levou o seu público com ele através do desenvolvimento dos seus estágios: adolescente fugitivo vivendo obsessivamente no presente, artista americano deslocado lutando para encontrar seu lugar no mundo, homem adulto procurando e retornando às suas raízes. É uma progressão que caracteriza não somente Shepard, mas também sua geração, e suas respostas pessoais reverberam através daqueles que estão partilhando da busca. Como Felícia Hardison Londre observa "as paralelas entre sua própria perspectiva e a época estão frequentemente claras" (Sam Shepard Works Out: The Masculinization of America em Studies in American Drama 1945-Present, 1987, p. 21). A busca de Shepard move-se da quase autista auto-absorção adolescente dos personagens em The Rock Garden até a madura comunicação atingida pelos personagens em A Lie of the Mind; ele descreve o círculo desde sua saída de casa até o seu retorno para casa.

\subsection{Uma Pesquisa de Literatura}

Existem vários estudos sobre o trabalho de Shepard, duas biografias populares duas antologias de crítica, e capítulos em vários trabalhos que tratam de teatro contemporâneo, assim como vários artigos em jornais e revistas. A análise do trabalho de Shepard considerada abaixo representa uma pesquisa da crítica literária na área, excluindo os frequentes e conflitantes julgamentos dos jornais sobre a obra de Shepard. Tentamos concentrar esse estudo nos escritos sobre as peças familiares.

O foco crítico derivará da frequência e profundidade da consideração crítica que tem em vista: (1) a relação das peças de Shepard com a tradição teatral e a prática teatral contemporânea; (2) literatura americana e cultura popular como fontes para Shepard; (3) a dimensão mítica dos trabalhos de Shepard; (4) paralelos entre a arte teatral de Shepard e a arte plástica e musical como um fator chave para interpretação; (5) interpretação social e teatral como um constante tópico do trabalho; (6) uso da língua; (7) gênero e relações masculino/feminino; (8) a identidade americana.

Não há uma unanimidade sobre o que precisamente constituem os períodos de desenvolvimento do trabalho de Shepard, as peças desde 1969 são freqüentemente consideradas juntas; as peças 'escritas em Londres' até 1977 constituem uma fase intermediária; aquelas relacionadas às famílias nucleares, iniciando com Curse of the Starving Class, constituem um terceiro período. Ron Mottram, por exemplo, utiliza essa divisão no seu estudo sobre Shepard. Similarmente, Ruby Cohn agrupa as peças em "colagem, fantasia e as recentes, realismo trágico" (New American Dramatists 19601980, 1982, p. 171). Esse último grupo, das peças familiares, é o mais consistentemente reconhecido como constituindo um período artístico unificado do trabalho de Shepard. Nesse estudo nos referimos aos três grupos como as peças iniciais, as peças da fase intermediária e as peças familiares. 
As qualidades específicas no trabalho de Shepard que os críticos escolhem para enfatizar inevitavelmente mudam com o seu desenvolvimento. Além da preferência individual crítica por um estilo ou forma sobre o outro e o lugar filosófico dele ou dela também tem um papel importante. Por exemplo, a preferência de Bigsby por Operation SideWinder, a peça teatral mais evidentemente política de Shepard, é única para Bigsby. A preferência de Marranca é por Action, uma peça que ela vê como reveladora da condição americana, mas influenciada por sensibilidades e práticas contemporâneas européias. Tooth of Crime "permanece como um ponto crítico de referência para muito da crítica sobre Shepard" (KLEB, 1983, p. 407). Herbert Blau, por exemplo, usa Tooth of Crime como modelo do trabalho do dramaturgo em seus dois artigos sobre Shepard. Da mesma maneira, Robert Coe considera Tooth of Crime a melhor das "peças de rock" e perfeita como um exemplo do trabalho de Shepard (em MARRANCA, 1981, p. 60). Muitos críticos focam nas peças mais recentes; entretanto, explicações sobre as peças familiares serão aprofundadas nos capítulos dedicados a elas.

\subsection{Os Trabalhos de Shepard no Contexto Teatral}

As primeiras respostas às peças iniciais de Shepard, tanto forte crítica quanto elogio, foram frequentemente vociferantes. Michel Smith, crítico do Village Voice, foi o primeiro, e por um tempo o único, crítico de Nova Yorque a defender Shepard. O interesse de Smith nas peças e aparente compreensão das mesmas profundamente influenciaram subsequentes críticos. Ele chamava as peças de Shepard de "teatro gestalt". Numa descrição resumida das peças iniciais, Smith escreve:

Todas as peças de Sam usam o palco para projetar imagens: elas não se relacionam com o espectador refletindo uma realidade exterior (elas não são psicológicas ou políticas); preferencialmente elas se relacionam com a realidade operando diretamente na mente e nos nervos do espectador. As imagens são surreais, o método não racional, a sensibilidade pressentida. (MARRANCA, 1981, p. 159)

A busca convencional por significado, em outras palavras, é apropriada para um dramaturgo que, nas palavras de Michael Bloom: "transmite uma sensação visceral imediata da realidade contemporânea" (MARRANCA, 1981, p. 76). Entre outros rótulos ligados às peças iniciais estão "colagem dramática" (George Stambolian, Ron Wetzsteon), "pensado de um modo dramático" (Ren Frutkin) e "peças imaginárias" (Gerald Weales). Weales e Bigsby focam nas qualidades alucinatórias das peças iniciais comparando-as a viagens alucinatórias proporcionadas por drogas, assim como Jack Gelber, que diz:

\footnotetext{
“... num vislumbre reconhecemos que elas são viagens. Não somente os personagens nelas estão viajando, pois eles nos dizem isso, mas também as formas das peças estão em formato de viagens, buscas, aventura. Muitos dos personagens estão sob efeito de drogas, sob o efeito de música, e outros estão voando nas suas palavras" (MARRANCA, 1981, p. 46).
}

A necessidade crítica de caracterizar trabalhos de literatura como algo que continua ou rejeita a tradição literária é algo que fornece um lugar na crítica sobre Shepard. Enquanto George Stambolian coloca Shepard dentro do contexto dos seus contemporâneos Off-Broadway, outros críticos o colocam paralelo a corrente principal do teatro americano ou europeu. 
A influência do Open Theatre (grupo de teatro experimental ativo de 1963 a 1973, fundado em Nova Yorque) é frequentemente declarada ou suposta de trabalhar as transformações dos personagens das peças iniciais. Richard Gilman observa essa influência e afirma que, "Shepard carregou a ideia de transformações muito além do que o grupo o fez ao na realidade escrevê-las nos textos..." (p. xvii). Escrita colaborativa com a companhia, também uma característica do Open Theatre, foi o método usado para Inacoma (SHEPARD, 1977) que foi encenada no Magic Theatre no mesmo ano, mas não pode ser nomeada como um modo característico particular de trabalhar para Shepard. A associação de Shepard com Joseph Chaikin (falecido em 2003) é o foco do editor Barry Daniels na sua compilação da correspondência entre Shepard e Chaikin.

Atrás do imediato meio teatral dos anos 60, 70 e 80 eleva-se a tradição do realismo americano com suas raízes continentais. Convenções realistas ou naturalistas fornecem um ponto de partida para muitos críticos. (4) Ron Wetzsteon, na sua introdução a Fool for Love and Other Plays (SHEPARD, 1984, p. 4), discute as respostas da platéia para as peças de Shepard e observa que:

\begin{abstract}
Os personagens de Shepard frequentemente parecem desmotivados, implausíveis, e inconsistentes a princípio - não porque eles são inverídicos à vida, mas porque nós confundimos 'fiel à realidade' com as convenções do realismo psicológico... - frequentadores de teatro são confundidos não somente pela aparente distorção da experiência como pela recusa dele em seguir as fórmulas que correspondem a experiência geral.
\end{abstract}

Wetzsteon conclui que as peças iniciais de Shepard "eram na realidade sobre a atmosfera altamente carregada delas" (SHEPARD, 1984, p. 4). Por conseguinte as afirmações dele de que o que distingue Shepard é a rejeição ou transformação da convenção teatral e a realização de "um tipo de hiper-realismo no qual (1) "o espaço é emocional em vez de físico"; (2) "o tempo é imediato em vez de sequencial"; (3) "a narrativa é uma questão de consciência em vez de conduta" e (4) "o personagem é espontâneo em vez de coerente" (SHEPARD, 1984, p. 7-8).

Richard Gilman, na sua introdução a Seven Plays (SHEPARD, 1981, p. xvi), vai além da estratégia não interpretativa preconizada por Ross Wetzsteon. Sua visão do relacionamento de Shepard com a tradição teatral é que:

O que distinguia as peças de Shepard da maioria do repertório americano era a grande vivacidade e elasticidade das mesmas, até mesmo suas maiores impurezas, a presença nelas de tantas energias e ações não pensadas propriamente dramáticas anteriormente. Mais que nenhum outro dramaturgo dos anos 60, ele demoliu as definições fixas do dramático.

Gilman acredita que uma clara compreensão do trabalho de Shepard requer tanto da platéia quanto dos críticos a aceitação "pelo menos provisoriamente, da sua volatilidade e interdependência; elas constituem uma série de facetas de um único ato contínuo da imaginação" (p. xviii).

Lynda Hart (1984, p. 82) no seu estudo de Shepard, também afirma que o trabalho de Shepard constitui um todo imaginário, mas ela coloca Shepard dentro do alcance das formas dramáticas tradicionais. Ela caracteriza as peças iniciais como "variações do expressionismo", invocam "metateatricalidade" como descritiva das peças 
intermediárias e aceita as últimas peças como "naturalistas", se bem que com uma diferença:

\begin{abstract}
Mas as peças de Shepard nos atingem como radicalmente diferentes por causa da convergência da forma naturalista, cognitiva e realista, com ação perturbadora que exatamente inverte as expectativas da platéia. Motivos são deixados não descobertos; o passado é revelado, mas fracassa ao tentar iluminar o presente; personagem torna-se cada vez mais desorganizado e a ação imprevisível. As duas formas antiéticas chocantemente combinam para produzir uma ação inexplicável e apreensiva, que oprime nossa habilidade de fazer observações inteligíveis.
\end{abstract}

Marranca (1981, p. 23) credita Shepard com uma "revitalização do realismo" dizendo que, "suas peças mudam os contornos do discurso, e, portanto, a comunicação no realismo".

A experimentação e realismo/naturalismo dos anos sessenta não são as únicas tradições teatrais com as quais as peças de Shepard estão relacionadas. A admiração de Shepard pelo trabalho de Samuel Beckett induz a frequente afirmação de influência, e, na realidade, alguns críticos vinculam Shepard com o teatro do absurdo ou citam como faz Bigsby, suas sensibilidades em relação e esse tipo de teatro (1985, p. 238-239). James Leverett (Associate Professor of Dramaturgy and Dramatic Criticism from Yale School of Drama) o coloca na mesma arena sem o anexar a um nome específico: "O dramaturgo que talvez mais do que nenhum outro representa a mudança do teatro avantgarde da Europa para América é Sam Shepard” (p. 29). William Kleb e outros também encontram traços em comum com Edward Albee, uma influência direta e reconhecida em duas peças do inicio dos anos sessenta. "A relação com Pinter, tão aparente para tantos críticos, permanece não reconhecida por Shepard", de acordo com Kleb (em MARRANCA, American Playwrights since 1945, 1981 p. 403). Stewart McBride cita o escritor austríaco Peter Handke (também autor de teatro, romances e poesia além de roteirista) como tendo um impacto em Shepard, assim como o faz Marranca que observa essa influência particularmente em Action (SHEPARD, 1975). Os traços em comum observados pelos críticos, entretanto, são raramente reivindicados como diretos; influências reconhecidas conscientemente, mas são vistos como resultado dos envolvimentos geracionais e teatrais de Shepard.

Bertold Brecht, outra influência sutil no teatro europeu do século vinte, também figura nas discussões de Shepard. A filosofia de Brecht sobre relações entre ator e personagem, seus fins sem soluções e seu uso de música são invocados pelos críticos do autor em questão nesse estudo. Ele uma vez mencionou que Brecht era seu "dramaturgo favorito" (CHUBB, 1974, p. 202). Ele na maioria das vezes repudia tanto a preocupação política quanto a intenção didática e como consequência os críticos contrastam ao invés de comparar os dois dramaturgos - meios similares para fins diferentes. A consciência dual do ator, como Shepard a emprega, é discutida em relação ao desempenho social como um tema no seu trabalho.

Muitos críticos julgam que as peças de Shepard são metateatrais, isto é, teatro sobre teatro. Sheila Rabillard (Sam Shepard: Theatrical Power and American Dreams, 1987, p. 58) propõe, numa análise linguística, "que os dramas de Sam Shepard podem ser considerados como, em alguns aspectos essenciais, explorações da teatralidade". Marranca invoca Brecht e Pirandello, ambos são exemplares da dramaturgia metateatral, 
como fontes para as noções de personagem de Shepard. Lynda Hart (The frontiers of American Drama: The plays of Sam Shepard, 1984, p. 14) escreve:

A chave para o novo teatro era a autoconsciência do artista; as novas formas eram auto-reflexivas, chamando a atenção para elas mesmas como artifício...as peças iniciais de Shepard são distintamente metateatrais.

Para ela, a mudança evolucionária na dramaturgia de Shepard envolve uma movimentação que se afasta do metateatro com The Tooth of Crime (SHEPARD, 1972) e "assinala a transição de Shepard das imagens de uma realidade teatral para uma apresentação metafórica do mundo fora do palco" (p. 67).

\subsection{O americanismo de Shepard}

Universalmente, os críticos identificam nas peças de Shepard um americanismo inextirpável. Os títulos e subtítulos das críticas sobre Shepard anunciam essa identificação: American Dreams (MARRANCA, 1981) "A Masculinização da América" (LONDRE, 1987), "Poder Teatral e o Sonho Americano" (RABILLARD, 1987), Sam Shepard: The life and work of na American dreamer (OUMANO, 1987), "O Sonho Americano no Gótico Americano" (BLAU, 1984).

O americanismo da mitologia de Shepard e da cultura popular cujas imagens ela tão frequentemente emprega são amplamente reconhecidas na literatura crítica. A compreensão de que Shepard está lamentando a perda da terra e do 'sonho americano' tornou-se um lugar comum. Se as qualidades americanas de Shepard são de alguma maneira tradicionais, entretanto, é uma questão em aberto. Na visão de Gilman, "Shepard parece ter saído de nenhuma tradição literária ou teatral, mais precisamente da quebra ou ausência - no nível da arte senão do comércio - de todas essas tradições na América" (Seven Plays, 1981, p. xiii). Outros críticos encontram fortes conexões entre Shepard e aqueles que eles identificam como seus antepassados literários.

Michael Earley, na antologia de Marranca, localiza Shepard dentro do contexto da literatura não dramática chamando o dramaturgo de "um naif (artista primitivo moderno) literário verdadeiro", ligando-o com "temas e convenções do Transcendentalismo e Romantismo" e "o recurso de impulsos míticos" de Hawthorne, Melville, e especialmente Walt Whitman (p. 126-132). Kleb responde que se Shepard tem um lugar nessa tradição:

É porque os espíritos de Emerson, Melville, Hawthorne, e Whitman (Shepard leu obras desses autores e os admirava) dialogaram com ele não diretamente, mas através das lentes de John Houston e John Ford e das páginas e bocas de Jack Kerouac, Allan Ginsberg, Gregory Corso e Bob Dylan. (MARRANCA, 1981, p. 403)

Marranca (1981, p. 29), que se refere a Walt Whitman como "o primeiro poeta beat" ${ }^{1} \mathrm{e}$ afirma que os personagens de Shepard "carregam o legado beat na forma dramática".

\footnotetext{
${ }^{1}$ É um termo usado tanto para descrever a um grupo de artistas norte-americanos, principalmente escritores e poetas, que vieram a se tornar conhecidos no final da década de 1950 e no começo da década de 1960, quanto ao fenômeno cultural que eles inspiraram posteriormente chamados ou confundidos aos beatniks, nome este de origem controversa, considerado por muitos um termo pejorativo. Estes artistas levavam vida nômade ou fundavam comunidades. Foram, desta forma, o embrião do movimento hippie, se confundindo com este movimento, posteriormente. Muitos remanescentes hippies se auto-intitulam
} 
Ela também diz que: "As peças de Shepard são atos de fé, e a resposta emocional dele em ser um americano reflete a característica busca americana pelo renascimento, e seu oposto, a negação da história" (p. 28). Herbert Blau inventa o adjetivo "Whitmanian" para descrever as histórias que os personagens de Shepard contam (American Gothic, 1984, p. 524). Bigsby (1985, p. 249) menciona as ligações de Shepard com os poetas Kerouac e Ginsberg e também conecta o dramaturgo aos romancistas contemporâneos americanos. Como os poetas e romancistas, Shepard expressa, "as ansiedades e, às vezes, as esperanças ingênuas de uma sociedade para quem os mitos da cultura popular são simultaneamente paradigma e comentário irônico".

Vivian Patraka e Mark Siegal identificam Shepard não somente como distintamente americano, mas como escritor ocidental regional, uma identificação que eles não discutem conclusivamente, mas que facilmente se percebe quando falamos de um dramaturgo cuja obsessão com o oeste americano, que aparentemente conduz diversas das peças e obviamente inspira tantas das suas imagens. Marranca também lida com Shepard como especificamente ocidental, afirmando que a discussão de regionalismo inicia com a transferência de Shepard dos "valores do oeste americano e seus ideais para a paisagem emocional das suas peças, destacando a função de espaço como mito" (1985, p.19). Para Marranca, a "fronteira ética" essencialmente conservadora de Shepard e seu "radicalismo no estilo dos anos sessenta" puxam um contra o outro para criar seu "americanismo essencial" (1981, p. 22).

Mottram também vê Shepard como americano. No seu resumo sobre a carreira de Shepard ele afirma:

O grande significado das peças de Shepard e o ponto de contato para sua platéia é que essa paisagem interior é também profundamente uma paisagem americana, memorável, como Ruby Cohn assinalou, não tanto por temas como por imagens e ritmos. São suas imagens e ritmos, frequentemente extraídos de várias expressões da cultura popular e dos meios de comunicação, que também fazem Shepard unicamente americano e intensamente moderno. (Inner Landscapes: The Theatre of Sam Shepard, 1984, p. 159).

A visão de Gilman é similar a de Mottram quando ele enumera as influências do pop americano e contra cultura nos temas, referências e iconografia de Shepard:

O mais substancial entre eles é o carro ou cultura da "estrada" da sua juventude, ficção científica, os filmes de faroeste Hollywoodianos e o mito do oeste em geral, e a televisão nos seus aspectos pop e de velharia. Além desses Shepard mencionou "vaudeville, circo... música de indução ao transe, cerimoniais de cura pela fé... shows de medicina", para os quais podemos adicionar estados telepáticos, experiências alucinatórias (induzidas por drogas ou não), além de mágica e bruxaria. (SHEPARD, Introduction. Seven Plays, 1981, p. xv).

A cultura popular americana é universalmente mencionada como uma característica de Shepard e fornece um fundamento crítico para análise de algumas peças. George Stambolian refere-se à Mad Dog Blues como “uma viagem através da cultura popular” e

'beatnicks' e um dos principais porta-vozes popular do movimento hippie, John Lennon, se inspirou na palavra 'beat' para batizar o seu grupo musical, The Beatles. Na verdade, a "Beat generation", tal como os Beatles, o movimento hippie e, antes de todos estes, o Existencialismo, fizeram parte de um movimento maior, hoje chamado de "contracultura". 
fala de Shepard e outros escrevendo peças as quais "tratam da condição de americanos modernos vivendo num mundo saturado pela mídia popular e particularmente pelos clichês, fantasias e histórias de cinema" (American Dreams, 1981, p. 79). Essas imagens da cultura popular, Stambolian declara, formam uma tela através da qual, como indivíduos, vemos o mundo. Bigsby do mesmo modo afirma que:

\begin{abstract}
Shepard tende a saquear o mundo da música e filme popular porque eles geram praticamente o único fundo comum de imagens e porque eles incorporam aquela substituição de estilo por substância, da superfície por profundidade, a qual parece tanto uma estratégia evasiva quanto uma possível fonte de energia". (A Critical Introduction to Twentieth Century Drama 3: Beyond Broadway, 1985, p. 222).
\end{abstract}

Stephen Putzel Expectation, Confutation, and Revelation: Audience Complicity in the Plays of Sam Shepard, 1987) vê esse fundo comum de imagens de filmes, combinado com a consciência do público sobre sua origem, como a chave para compreensão da recepção do trabalho de Shepard por parte do público. Particularmente em Angel City (1976) e Suicide in B Flat (1976), Putzel mantém, que Shepard evoca "a semiologia do filme" para criar um palco duplamente emoldurado forçando assim a leitura de uma platéia cúmplice da peça encenada dentro de um contexto de um filme. Dois outros críticos consideram o uso da técnica fílmica narrativa que Shepard usa: Dennis Carroll em "The Filmic Cut e 'Switchback' nas peças de Sam Shepard", o qual foca nas peças iniciais; Carol Rosen em "Angel City de Sam Shepard: um filme para o palco".

\title{
1.7 O Uso de Mito em Shepard
}

Segundo Mircea Eliade, a tentativa de definir mito é a seguinte, "o mito é uma realidade cultural extremamente complexa, que pode ser abordada e interpretada em perspectivas múltiplas e complementares... o mito conta uma história sagrada, relata um acontecimento que teve lugar no tempo primordial, o tempo fabuloso dos começos... o mito conta graças aos feitos dos seres sobrenaturais, uma realidade que passou a existir, quer seja uma realidade total, o Cosmos, quer apenas um fragmento, uma ilha, uma espécie vegetal, um comportamento humano, é sempre, portanto uma narração de uma criação e descreve-se como uma coisa foi produzida, como começou a existir..." (ELIADE, Aspectos do Mito, 2000, p.12/13).

Para Carl Gustav Jung (O homem e seus símbolos, 1964), discípulo de Freud e seu colaborador por muitos anos, os mitos seriam uma das manifestações dos arquétipos ou modelos que surgem do inconsciente coletivo da humanidade e que constituem a base da psiquê humana. A existência do inconsciente colectivo permite compreender a universalidade dos símbolos e dos mitos, pois que estes se revelam em todas as culturas e em todas as épocas de modo idêntico.

Como diz Joseph Campbell (O Poder do Mito, 2006): "aquilo que os seres humanos têm em comum revela-se nos mitos. Eles são histórias da nossa vida, da nossa busca da verdade, da busca do sentido de estarmos vivos. Os mitos são pistas para as potencialidades espirituais da vida humana, daquilo que somos capazes de conhecer e experimentar.

Congruentes com a consideração da confiança de Shepard na cultura popular, Lion Bigsby, em particular, invoca o mítico como a essência da estética de Shepard "a qual 
se apóia numa resposta subjetiva do seu público, na participação deles num mundo de mito contemporâneo o qual é um equivalente moderno da literalidade mitológica do mundo antigo" (p. 227). William Kleb e Steven Putzel, ambos afirmam que a mistura das mitologias das peças e do dramaturgo foi o que resultou da imagem de estrela de cinema de Shepard. Enquanto quase todo crítico usa "mítico" ou "mito" para descrever os temas ou personagens das peças, o que também seria verdade no caso de Shepard, uma vez que vários dos entrevistadores parecem ter introduzido esse tema, poucas análises míticas de suas peças foram efetivamente realizadas. Entre os poucos autores que discutem essa questão estão Albert E. Wilhelm que usa tal orientação para discutir Icaru's Mother (KING, 1988, p. 21-30); o autor discute o "mítico" como um assunto crítico, algo mais frequente em discussões das peças familiares, e Tucker Orbison, que escreveu sobre esse mesmo aspecto em "Níveis míticos na peça True West de Sam Shepard".

Talvez de maneira menos óbvia em True West do que em suas peças anteriores, a presença do mito ainda está lá, às vezes ajudando a criar material temático consciente sobre o que pode ser chamado de níveis artísticos sócio-históricos, e também sempre trabalhando num nível psicológico.

Austin, em True West, sinaliza que os valores do mito americano do velho oeste estão extintos quando ele grita com Saul: "There's no such thing as the West anymore! It's a dead issue! It's dried up, Saul, and so are you"' (p. 35).

Para Shepard o mistério reside no coração do mito. Para ele o mito carrega esse sentido de mistério e não é necessariamente uma fórmula tradicional. Ele cria o mesmo de acordo com uma estrutura com fim aberto onde qualquer coisa poderia acontecer e que é diametralmente oposta a um evento cuidadosamente planejado e regurgitado. Este processo criativo, cujo final traz um sentido de mistério, pode somente ter nascido de uma consciência mítica, funcionando como agente de renovação. Ele utiliza elementos míticos em suas peças, pois acredita que o mito causa um curto circuito no intelecto e o conecta com sentimentos.

\subsection{Intuições de outras artes}

Na introdução de Fool for Love and Other Plays, Ron Wetzsteon (1984, p.14) reitera um tema crítico:

O trabalho de Shepard é baseado no jorrar espontâneo de sentimentos, na recusa a ser confinado pelas formas culturais ou intelectuais herdadas. Nesse aspecto, sua linhagem inclui Jackson Pollock assim como os Rolling Stones e Walt Whitman.

Pintura, música e poesia. Muitos críticos fazem analogias entre os trabalhos de Shepard e a estética das artes gráficas e música . Gay Gibson Cima (1986) afirma que:

As peças de Shepard incorporam princípios estéticos muito similares aos usados por Robert Rauschenberg, e ao tratar desses princípios poderemos melhor compreender como ler, encenar e dirigir os trabalhos desse dramaturgo controverso. (Shifting Perspectives: Combining Shepard and Rauschenberg, 1986, p.67-68). 
Entre as similaridades que Cima encontra estão: 1. "uma atmosfera rude e não planejada"; 2. "uma recusa em fornecer uma estrutura física ou mental definitiva"; 3. "uma ruptura absoluta da narrativa". Ela argumenta que essas qualidades forçam os espectadores "a escolher uma maneira de ver, de perceber o 'real' e o 'não-real' no trabalho do dramaturgo" (1986, p. 69-70). Toby Silverman Zinman (Sam Shepard and Super-Realism. Modern Drama 29, 1986, p. 423-30) no seu artigo amplia a referência feita por Gilman sobre a estética da pintura hiper-realista ou super-realista mencionando o trabalho de Shepard. "Conectado por atitudes assim como por ícones," o qual Zinman enumera, tanto os pintores como o dramaturgo "distanciam-se do conceitual em direção a tudo relativo à percepção". O que é criado tanto por Shepard quanto pelos superrealistas é "uma estética agressiva que exige nosso comprometimento visceral com a encenação mais do que com o enredo". (1986, p. 423-424). Zinman também descreve uma alternativa estética trabalhada nas peças do período inicial, a estética da música. Ela escreve: "a música parece informar cada aspecto do ambiente teatral, não é um mero mecanismo decorativo" (Shepard Suite, p.16). Shepard frequentemente escreve canções de rock para suas peças e utilizou músicos para tocar música composta ou improvisada, ou canções específicas por artistas específicos sob as suas diretrizes de palco.

As "peças com canções de rock" são reconhecidas e discutidas como uma unidade por Robert Coe e outros, e, de acordo com Richard Gilman, o rock \& roll contribui para a linguagem de palco de uma maneira contemporânea. $O$ rock, entretanto, não é a única forma musical impregnando os trabalhos de Shepard. Gilman também inclui "jazz, blues, country e música folclórica de vários tipos" como parte integral do teatro de Shepard e essencial para sua compreensão. O jazz "existe como princípio estrutural e imagético em várias peças de Shepard”, de acordo com Bigsby (1985, p.225).

As influências e manifestações musicais nos trabalhos de Shepard são prontamente assumidas muito mais do que modelos ou influências teatrais. Em "Nota para os Atores" no prefácio de Angel City, Shepard afirma:

\begin{abstract}
Ao invés da ideia do "personagem completo" com motivos lógicos por trás da sua conduta nos quais o ator mergulha; ele deveria considerar um todo fragmentado com uma miscelânea de personagem saindo da trama central. Em outras palavras, mais em termos de uma colagem ou improvisação de jazz. (Fool for Love and Other Plays, 1984, p.61-62).
\end{abstract}

A sua própria musicalidade e sua ambição em tornar-se um astro do rock servem de ponto de partida para muitos críticos e entrevistadores.

\title{
1.9 Representação teatral
}

O reconhecimento da preocupação de Shepard com identidade como um produto da representação teatral é mencionado pela maioria dos críticos. Florence Falk afirma que "cada peça de Shepard é estruturada numa série de rituais de representação," e "os modos mais populares são diálogos, contar histórias e compor músicas" (The Role of Performance, p. 183,188). Enquanto Falk reconhece a dimensão teatral da representação ela leva em consideração implicações psico-sociais. Ela conclui:

Nós atingimos aquele ponto no tempo, Shepard parece sugerir, quando sentimentos dramatizados parecem mais reais, são mais confortáveis e certamente estão mais disponíveis para nós do que os sentimentos reais. Nas peças de Shepard o paradoxo da representação significa que os rituais de 
representação podem levar a um aprisionamento do ego assumido ou uma descoberta e recuperação do ego real ou natural. (The Role of Performance, p. 185)

Para Florence Falk existe também uma dimensão política mais ampla para alguns dos rituais de representação usados por Shepard, aqueles empreendidos pelo artista xamanista ou sacerdotal "para alterar as circunstâncias sociais coletivas e mediar contra o desastre, e o seu escopo é nada menos que o escopo e amplitude da humanidade no todo". (The Role of Performance, 1981, p.195)

Bonnie Marranca também contribui para essa discussão de uma perspectiva mais teatral. Ela relaciona os personagens de Shepard aos seus antecedentes pirandelianos e brechtinianos e afirma que o personagem de Shepard "está livre para remover sua máscara... para deixar, mentalmente e em outra estrutura temporal, a peça e verbalizar suas respostas emocionais em relação aos eventos ao seu redor" (1981, p. 25) Marranca menciona a distinção entre "personagens que são lentes deles mesmos" nas peças iniciais e aqueles das peças familiares que "são pegos no mundo do Destino, da Necessidade".

Gerald Weales identifica a representação e "a invenção do ego" como um tema recorrente nas peças de Shepard (em American Dreams, 1981, p.38). Ren Frutkin também observa certa influência biográfica em sua análise das peças iniciais cujo tema central ele identifica como sendo: "the value of performance. I mean here performance as the shared style of a generation, the theatricalization of everyday life" (p. 110). Porque a representação de uma peça necessita sempre de uma platéia, uma existência emparelhada permeia as peças, Frutkin acredita que:

As peças de Shepard lidam com a mutualidade de desastres, do qual ele é o herdeiro, fazendo do seu tema dramático o personagem como ator e confrontando o princípio de encenação que, mesmo a mais apreciada das quatro celebrações é limitada. (em American Dreams, 1981, p. 116)

Linda Hart acredita que Shepard emprega 'a representação dramática como uma metáfora para existência’ (1984, p. 47). A visão dela une representação metateatral e social:

\footnotetext{
A consciência dupla do ator, como uma pessoa que encena para outros ao legalizar um papel criado por um dramaturgo, e como um indivíduo que desenvolve um conceito de si mesmo através dos papéis que ele ou ela encenam no palco, é crítico para uma compreensão do pensamento que comunica o drama de Shepard. Porque os atores não somente experenciam essa consciência dupla, eles também a representam como espelhos da consciência contemporânea. (1984, p. 59)
}

Mantendo essa mesma linha de pensamento de que no teatro de Shepard o personagem deve ser espontâneo em vez de coerente, Wetzsteon (1984, p. 8) acredita: "We make ourselves up as we go along, his plays suggest, for, in yet another paradox, that kind of spontaneity of self is the only way to discover the integrity of self". Para Wetzsteon, o que ele chama de "this sense of eternal renewal" é evidência do americanismo essencial de Shepard. 
Gilman considera "the performing self" como a perspectiva sob a qual "all Shepard's themes or motifs can be subsumed" (1981, p. xxi). Reconhecendo a busca por identidade como "central to Shepard's vision" ele se questiona se, "And might not the quest for identity really be the quest for a role?" Ele conclui que "we either take our places in a drama and discover ourselves as we act, or we remain unknown" (1981, p. xx) Gilman (1981, p. xxiv) considera The Tooth of Crime uma das grandes realizações de Shepard, parcialmente porque "it broods on and wrestles with the quest not simply to be known but to be known inexhaustibly, magically, cosmically[...]". A preferência dele por essa peça é compartilhada por Herbert Blau ("it may be his most brilliant play") que examina Tooth of Crime em dois artigos, onde ele leva em consideração "the quest for identity through the performing self, undertake the subject from the perspective of language".

\subsection{0 uso da linguagem por Shepard}

Como Phyllis R. Randall (Casebook, 1988, p. 121) observa, "The impact and range of Shepard's language are noted by just about everybody who writes about him". Blau, por exemplo, elogia o domínio dos vernáculos subculturais americanos, assim como Ruby Cohn que diz: "Shepard's language, particularly his command of slang, is his most distinctive attribute". Bigsby afirma que: "Shepard is centrally concerned with language", particularmente com sua "incantatory power, its rhythmic associations, its power to provoke the imagination" (1985, p. 232).

Sheila Rabillard também se interessa pelo poder da linguagem de Shepard. Quando escreve sobre Icarus's Mother, ela diz: "the words spoken by the characters in the play are the bearers of power, rather than of meaning" (Sam Shepard: Theatrical Power and American Dreams, in Modern Drama, Vol. XXX, No. 1, March, 1987, p. 60). Rabillard acredita que "what the characters say is what they do to each other" e que Shepard "exposes this function of theatrical language to us by removing virtually any other" (Theatrical Power, 1987, p. 60-61). Através do uso da linguagem fática, "Shepard discloses to the spectator structures of theatrical discourse and invites him to become aware of exercises of power" (Theatrical Power, 1987, p. 62). Para ela, esse forçar de atenção é o que confronta a platéia com a teatricalidade vazia da vida contemporânea.

Num outro artigo sobre Shepard, Rabillard sugere que tanto ele, como Harold Pinter enfatizam uma ordem local nas peças de sua autoria que empregam princípios estruturais da linguagem: "series and permutation, patterns of rhetoric and syntax" (Destabilizing Plot, Displacing the Status of Narrative: Local Order in the Plays of Pinter e Shepard, 1991, p. 57). Essas "smaller-scale constructions", ele argumenta, "disrupt narrative and destabilize traditional notions of both plot and character by calling attention to themselves" (Destabilizing Plot, Displacing the Status of Narrative: Local Order in the Plays of Pinter e Shepard, 1991, p57).

A maioria dos críticos, que abordam as peças de Shepard de um ponto de vista linguiístico e pós-estruturalistas mantem o olhar voltado para o que a linguagem de Shepard procura, linguagem como expressão de desejo. O que encontramos no pensamento pós-estruturalista nos sugere um questionamento: até que ponto a identidade pode ser, num mundo feito de palavras, uma mera questão de palavras? Herbert Blau analisa Tooth of Crime como: "Shepard's refusal of too much theatre by theatre" (1984, p. 560). Ele comenta: 
A persistência do desejo na linguagem para superar a promessa fracassada...: como o drama americano lembra através de cada desencantamento as características soltas e fugazes do sonho americano, relacionadas à imagem indefinidamente recuada da inocência perdida (1984, p. 521).

Ann Wilson (1987, p. 137) aborda a linguagem e o problema da presença nas peças de Shepard e comenta: "Shepard seeks to discover within himself the language which will make the signified fully present by overcoming loss which attends the separation of the signifier and the signified". Wilson menciona esse desejo não realizado e/ou irrealizável como a fonte de um desejo ardente nos personagens cujos apetites incitam suas ações. De maneira similar, Leonard Wilcox (Language and Desire: The Abject in Shepard's Red Cross. King, Kimball. Sam Shepard: A Casebook, 1988, p. 107-120. Casebooks on Mod. Drama; v. no. 2) trata Red Cross (SHEPARD, 1966) como um exemplo de degradação: a dominação da autoridade maternal pela lei paternal através da ordem simbólica.

Phyllis Randall escreve sobre a modelagem de Shepard da fecundidade dos dialetos e vozes que caracterizam as primeiras peças nos solos e solilóquios das últimas peças. A justaposição desses monólogos com as conversas comuns nas peças familiares prepara a platéia para enfrentar a nova realidade.

\subsection{Homens e mulheres nas peças de Shepard}

Alguns críticos exploram a maneira com que Shepard lida com os personagens femininos em suas peças e a política sexual das mesmas. Marranca, por um lado encontra muitos aspectos merecedores de elogio, porém lamenta: "the zero gravity of women. There is no expression of a female point of view in any of Shepard's plays" (em American Dreams, 1981, p. 30). "The voice of consciousness, of emotions, of reason, of triumph, and of failure, too and finally, of America is a man's voice" (p. 31). O que Marranca considera como "Shepard's oppressive view of women" é considerado por Blau como "his major limitation perhaps" e ele especula:

Permanece para ser visto... se ele pode retratar o corpo feminino como algo mais do que as coisas antigas, camuflado, concessivo, evasivo, passivo, como uma espécie de menina moleque superando a maldição ou um monograma de prostituta produzido pela máquina de sonhos de Hollywood. (American Gothic, 1984, p. 521).

Florence Falk (1981, p. 91) em Men without Women: The Shepard Landscape, escreve julgamentos similares: "In the plays of Sam Shepard, the cowboy is the reigning male; consequently, any female is, perforce, marginalized". E "as the disadvantage minority, women in Shepard's plays are compelled to adapt themselves as the best they can to the exigencies of the male world to survive" (1981, p. 99). Uma das estratégias de adaptação que as mulheres marginalizadas partilham com os homens de Shepard, é a encenação.

A Lie of the Mind é uma das peças de Shepard que divide a opinião dos críticos. Algumas análises mostram que os personagens femininos são diferentes dos das peças iniciais; outros os vêem da mesma maneira. Sheila Rabillard menciona uma diferença significativa na presença dos personagens masculinos e femininos no palco em Lie of the Mind: 
Muito do humor da peça vem das falas das mulheres porque elas mostram um auto-respeito de uma maneira que os homens não têm; elas atuam como seu próprio público, e vêem a si mesmas como são vistas. (Theatrical Power, 1987, p. 68)

Essa aliança entre o que ela parece ser para outros e o que ela é constitue para Rabillard, "Shepard's rendering of the dangerousness of woman's performance" (Theatrical Power, 1987, p.69).

O mundo do pai e o da mãe nas peças de Shepard é contrastado por muitos críticos. Entre eles, Doris Auerbach (1988, p. 53), que cita como exemplo: “Icarus's Mother, is no more important a character in the play than in the myth - there is no such character. She is thus an apt personification of the dominated, powerless mother figures in Sam Shepard's plays". A dicotomia mãe-pai é também vista como operante em True West e Fool for Love a qual é dominada pela ordem linguística do pai.

Um diferente ponto de vista é abordado por Rudolph Erben, quando ele afirma:

\begin{abstract}
As mulheres nas peças de Sam Shepard são modernas, independentes, e socialmente ativas. Elas transcendem os papéis de domesticidade e dependência dos homens. As mulheres participam da vida corporativa e comunal da América moderna, a qual substituiu a fronteira do individualismo masculino do passado. Por essa razão, as mulheres não podem ser a resposta para Sam Shepard porque elas transferem para o oeste a civilização do leste, de onde os heróis de Shepard tentam escapar. (Women and Other Men in Shepard's Plays, 1987, p. 29)
\end{abstract}

Essa análise mais excêntrica de Erben liga as mulheres com outros homens de Shepard, que representam a força destrutiva da civilização. Na visão de Erben, a família é a maldição da qual os protagonistas de Shepard tentam fugir.

Felicia Hardison Londre (1987, p. 20) vê os retratos das mulheres das peças de Shepard como um fator crucial para mapear sua maturidade crescente, a qual ela descreve como, "an unconsciously developing masculinity". Para ela as peças de 1976 até 1980 são: "adolescent masculine fantasies written in ignorance of dramatic technique". "Shepard's work reflected the process of coming to awareness of a young adult masculinity... He put himself through training to discipline his form" (1987, p. 20). Tanto Paris Texas quanto A Lie of the Mind demonstram uma fase tardia: "an enlightened recognition of the feminine component at its full value, whether it is within one human personality, or in any man-woman relationship, or in American society as a whole" (1987, p. 21). Londre julga que essa mudança autoral é sintomática de mudanças sociais simultâneas.

Charles G. Whiting observa uma mudança no tratamento de Shepard das mulheres nas suas peças:

Está evidente agora que as mulheres mais jovens de Shepard se tornaram mais evidentes em seu trabalho recente, e essa realização nos leva para uma perspectiva nova e mais favorável sobre as mulheres nas peças anteriores. (Images of Women in Shepard's Theatre, 1990, p. 494) 
Whiting credita a quatro das jovens mulheres nas peças familiares e Cavale em Cowboy Mouth (SHEPARD, 1971) esforços heróicos em encontrar renovação ao tentarem escapar das situações em que se encontram. Ele contrasta o tratamento de Shepard dessas cinco mulheres com a imagem negativa das mulheres mais velhas das peças de Shepard (Images of Women in Shepard's Theatre, 1990, p. 501).

\subsection{Sam Shepard e o Super-Realismo (Hiper-Realismo)}

O que se conhece como hiper-realismo ou foto-realismo é um fenômeno especificamente norte-americano e geralmente urbano que resultou de uma colisão entre o culto da arte pop pelo objeto iconográfico - moderno, fabricado e, sempre que possível novo e reluzente - e a resposta equivalente da fotografia diante desses objetos, sob uma luz artificial e estática. Essa arte polida, às vezes bastante habilidosa, foi também chamada de novo Realismo na época, para diferenciá-la do realismo granulado, socialmente inclinado dos anos 30 . Por volta do final dos anos 60, artistas como Richard Estes e outros causaram impacto nas exposições em Nova York. O compromisso social raramente estava presente em suas obras; na verdade, a emoção foi expurgada, abandonada em favor de um virtuosismo técnico e de uma imparcialidade diante do objeto que produz nas obras um curioso "fator teflon": o olho desliza pelo quadro, obrigando o espectador a agarrar-se no cinto de segurança da admiração pela técnica.

Se observarmos superficialmente, a precisão desinteressada de uma pintura superrealista ela não teria muito em comum com a energética vivacidade de uma peça de Sam Shepard. Mas o termo 'super-realista'" (ou 'hiper-realista) (1) embrenhou-se nas discussões sobre teatro contemporâneo, especialmente sobre as peças de Sam Shepard escritas nos últimos anos (após Curse of the Starving Class). O termo 'super-realista é com frequência usado para caracterizar o novo estilo de encenação que as peças de Sam Shepard requerem e que podem ser vistos em muitas produções Off-Broadway ${ }^{3}$ (2). Shepard afirmou em 1974 que ele queria tentar:

\footnotetext{
${ }^{2}$ Hiperrealismo ou fotorrealismo é um estilo de pintura e escultura, que procura mostrar uma abrangência muito grande de detalhes, tornando a obra mais detalhada do que uma fotografia ou do que a própria realidade. As obras hiperrealistas, por apresentarem uma exatidão de detalhes bastante minuciosa e impessoal, geram um efeito de irrealidade, formando o paradoxo: "É tão perfeito que não pode ser real".Teve início em 1968, expandindo-se no início dos anos 70, tendo grande popularidade em Inglaterra e nos Estados Unidos. Os artistas dessa corrente artística utilizavam o recurso da ampliação fotográfica, derivada da Pop Art - movimento iniciado no EUA na década de 60 do século passado que tinha como alvo principal toda cultura de massa. O Hiperrealismo aliou essa técnica ao uso de uma meticulosa iluminação e de reflexos naturais e artificiais, que conferem uma qualidade visual fantástica a imagens cotidianas, tais como: lojas de alimento, automóveis e reflexos em fachadas de vidros.
}

\footnotetext{
${ }^{3}$ Peças e musicais Off-Broadway são representados em Nova York em teatros menores do que os teatros da Broadway, porém maiores do que os das produções off-off-Broadway. Os teatros Off-Broadway possuem entre 100 e 499 assentos e sua classificação é gerenciada pelos contratos com a Actors' Equity Association, em vez de pela sua situação geográfica . Geralmente, as produções em teatros Off-Broadway são menos dispendiosas, investem menos em divulgação e são também menos conhecidas. A escala menor freqüentemente permite que obras mais experimentais e desafiadoras sejam apresentadas. Alguns grupos que produzem peças Off-Broadway não visam o lucro, o que significa que podem se aventurar em peças que podem não ser comercialmente bem-sucedidas; todavia, ainda tem de assegurar suficiente
} 
um modo completamente diferente de escrever agora, o qual é muito inóspito e ostentoso... Bem, poderia ser chamado de realismo, mas não o tipo de realismo onde esposos e esposas discutem ruidosamente e todo esse tipo de coisa. (p. 3)

Peças super-realistas e pinturas super-realistas (em especial aquelas feitas por Ralph Goings, Richard Estes, Robert Bechtle, John Salt, David Parrish, Tom Blackwell and Ron Kleeman) estão conectadas por atitudes e também por ícones. Sua movimentação está longe do conceitual, dirigir-se à área da percepção; longe da idéia, mas em direção ao fato ou evento.

Talvez a ligação mais óbvia e firme entre Shepard e todos os principais pintores superrealistas seja a conexão com a Califórnia. A preocupação com o 'cool', com a cultura popular e os seus artefatos materiais - mais visivelmente o automóvel - e a mitologia do oeste (verdadeiro ou falso) estão todos presentes. A penetrante masculinidade, o ser americano, e certa nostalgia pelo passado recente também os ligam, assim como um poderoso exagero, a tensão inevitavelmente criada pelo moderno, uma firmeza e uma dureza, não somente na escolha do assunto, mas no alto brilho da própria superfície, e no seu corolário, uma suposição da importância da superfície.

Esta ênfase na superfície tem um número de implicações significativas para as peças e para as pinturas. Existe em ambas uma frontalidade agressiva levantando-se da pouca profundidade da distância imaginativa entre a boca de cena e o último plano do palco, entre o primeiro plano e o plano de fundo. A investida é contra nós, a platéia. Isto cria uma dinâmica no palco a qual é essencialmente sobre encenação em vez de a quarta parede do realismo. Seu reconhecimento pela platéia é uma estética agressiva que exige nosso envolvimento visceral na encenação e não no enredo. Por exemplo, Shepard requisitou que as paredes do cenário de Fool for Love tivessem fios elétricos para reverberação e quatro alto falantes instalados embaixo dos assentos para que cada batida da porta envolvesse fisicamente a platéia. (5) Portanto, o espectador move-se para perto do participante. Como Jacques Levy (em Sam Shepard, OUMANO, 1986, p. 6) escreveu,

Sam está mais interessado em fazer algo para as platéias do que em dizer algo para elas, e o que ele quer fazer não tem relação com o purgar de emoções através de identificação ou total envolvimento.

Existe uma imediação tanto nas peças como nas pinturas que não será ignorada.

Fascinação com a superfície é certamente um dos determinantes primários do tema. As pinturas de Goings, Salt, Estes, Bechtle, Parrish e Kleeman estão repletas de carros, caminhões, motocicletas, com suas superfícies metálicas brilhantes, seus pára-brisas, janelas e espelhos. Geralmente os veículos estão estacionados próximos das vitrines de lojas ou lanchonetes. As superfícies de vidro e metal refletem, brilham e cintilam sob a intensa luz solar californiana. (As fotografias feitas por Johnny Dark em Shepard's Motel Chronicles parecem exatamente como material para essas pinturas foto-realistas.

interesse em suas peças para constituir uma ampla base de pagantes que os mantenham financeiramente saudáveis. Algumas produções comerciais encontraram um nicho lucrativo nos teatros Off-Broadway, que lhes permitiu estender-se por temporadas maiores do que as de seus teatros de origem. 
A maioria das fotos mostra Shepard ou alguém sentado ou em pé próximo de um carro, uma caminhonete, um caminhão, um trailer).

Richard Estes é provavelmente o mais obcecado por superfície desse grupo de artistas. Num ensaio em Art International, J. Patrice Marandel (1971, p. 58-61) iguala as vitrines de Estes aos espelhos de Van Eyck, pois eles refletem coisas que o observador não veria de outra maneira. Nós geralmente olhamos através do nosso reflexo na vitrine de uma loja para ver o que está dentro, mas Richard Estes nos força a olhar para a superfície da vitrine e ver o que ela reflete - isto é, o que está atrás do observador. O conjunto de imagens refletidas numa variedade de superfícies destorcidas dificulta ver, apesar de paradoxalmente, estarmos vendo com tamanha brilhante claridade. A própria declaração de Shepard: "Eu sou atraido por imagens que brilham no meio de refugo." (p. 9) poderia ter sido dita por qualquer um desses pintores.

A mais óbvia tradução de uma superfície refletida do visual para a imagem dramática é encontrada em Buried Child quando Vince nos conta sobre quando viu sua face no párabrisa:

\begin{abstract}
Estudei minha cara. Estudei tudo sobre ela. Como se eu estivesse olhando para outro homem. Como se eu pudesse ver a sua raça inteira atrás dele. Como o rosto de uma múmia. Eu o vi vivo e morto ao mesmo tempo. No mesmo fôlego. No pára-brisa, eu o assisti respirar como se ele estivesse congelado no tempo. E cada respiração o marcou. Marcado para sempre sem ele saber. E, em seguida, seu rosto mudou. Seu rosto tornou-se o rosto do pai. Mesmos ossos. Mesmos olhos. Mesmo nariz. Mesmo fôlego. E o rosto de seu pai mudou para cara de seu avô. E foi assim. Mudando. Claramente sobre rostos que eu nunca tinha visto antes, mas ainda reconhecia. Ainda reconhecia os ossos embaixo. Os olhos. A respiração. A boca. Eu segui a minha família direto até o Iowa. Cada um deles. Em linha reta até o cinturão do milho e mais. Para trás na medida em que eles me levavam. Então, tudo se dissolveu. Tudo se dissolveu. (SHEPARD, 1978, p. 10)
\end{abstract}

O reflexo e a refração infinita, a profundidade e as camadas da superfície, provocam Vince com significado. Assim como o reflexo no pára-brisa mostra a Vince sua ligação com o que está para trás dele, sob ele, antes dele, sua ligação com o passado americano, então a peça nos provoca com sua subcamada mítica. Esse sentido de camadas, de algo embaixo, obscurecido, mas ainda crucial, é básico da técnica do super-realismo. Todas as pinturas começam com uma fotografia (ou várias fotografias) e então o artista aplica tinta como se estive utilizando cosméticos.

Robert Bechtle, outro entre os principais super-realistas californianos, disse que o estúdio realista está interessado nas distinções sutis entre a marca no papel e a coisa em si: "Tentamos eliminar aquela diferença o máximo possível e recorremos à câmera para fazê-lo".

O novo atuar super-realista projeta o mesmo poder violento e exagerado das peças. Os atores devem ter grande coragem emocional e física assim como habilidade, e como correr riscos exige um grande grau de confiança, parece requerer e inspirar a melhor totalidade de encenação. Não nos pede que acreditemos que seja a vida real, mas que é uma encenação real. Da mesma maneira, uma pintura super-realista não nos pede que acreditemos estar olhando para um carro real, mas que estamos olhando para uma pintura real de um carro. Em Reality Again Harold Rosenberg (1975) escreveu que: 
Uma tela feita por Estes ou Goings é soldada à objetividade da câmera, e na medida em que as fotografias de coisas tornaram-se mais real para os americanos do que as próprias coisas que conseguem crédito superiores precisamente através da sua óbvia artificialidade.

John Lion, diretor artístico do Magic Theatre em São Francisco, disse para Shepard quando eles começaram a ensaiar Fool for Love: "Tem certeza que não está começando muito alto? Eles estão suando como porcos lá em cima".

Os atores realmente suam e, frequentemente, sangram no palco, e ainda assim estamos conscientes que eles estão no controle, de uma espécie de balé coreografado, mas brutal. Parte do efeito no observador de uma encenação super-realista ou pintura é saber como o ator ou pintor faz aquilo. A admiração é pela encenação, pelo exagero através da técnica.

Outro aspecto do super-realismo partilhado pelas pinturas e pelas peças é certa nostalgia pelo passado recente. Esse passado pode nunca ter existido, ou pode até ter sido desagradável, mas adquiriu uma pátina através de associações com a juventude de alguém. Em True West Austin chama isso de suas "fantasies of a long lost boyhood", e revelado sob aquela insolente superfície de clichê está a linguagem viva do desejo.

Os artefatos da nossa cultura que enchem essas peçam e pinturas - os automóveis, as torradeiras, cinzeiros, garrafas de ketchup, chapéus de cowboy, vinil e metal - sugerem uma redução radical na variedade e qualidade do mundo material. A tentação de interpretar esses trastes como uma indicação, como um comentário sobre o fim da civilização, é perigosa, e pode levar a distorção tanto das peças quanto das pinturas. Apesar de o super-realismo parecer ser um modo paródico, por sua excessiva falta de excesso, sua planura, sua insistência no próprio objeto, não é tão facilmente definida.

O super-realismo da torradeira em True West origina-se não do fato de as torradeiras serem 'reais' e funcionarem, mas do fato de existirem trinta torradeiras brilhantes espalhadas pelo teatro, todas torrando pão e enchendo o teatro com um intenso e maravilhoso cheiro de torrada.

No teatro, o tratamento super-realista é mais provável de manifestar-se no projeto do cenário. No início do Ato II de Buried Child existe essa troca:

Shelly (rindo, apontando para casa): É isso aí? Não acridto que seja isso!

Vince: É isso.

Shelly: Essa é a casa?

Vince: Essa é a casa.

Shelly: Não acredito!

Vince: Como pode ser?

Shelly: É como uma capa de Norman Rockwell ou parecido.

Vince: E qual o problema? É americano.

Shelly: Onde está o leiteiro e o cachorrinho? Qual é mesmo o nome do cachorrinho? Spot. Spot e Jane. Dick e Jane e Spot.

Vince: Pare com isso. 
Shelly não pára de caçoar, e ri cada vez mais até que ela está tão histérica, tão fora de controle que cai de joelhos. É o cenário aqui que deve dar para platéia a pista de como reagir à reação dela. Se o cenário é como o de uma capa feita por Norman Rockwell nós o registraríamos meramente como realismo (o tipo de cenário que provavelmente terá uma cozinha completamente equipada e coisas do tipo) e a excessiva reação de Shelly a definiria como cruel: muito jovem e muito moderna. De outro modo se considerarmos o cenário super-realista - talvez com o palco examinado minuciosamente, inclinando a varanda para a platéia, o céu pintado e iluminado para parecer acrílico ao invés do céu, os detalhes da casa reproduzidos com tamanha precisão que a fazem parecer estática, em última análise mais como um cenário do que como a vida real-então responderemos como Shelly e concordamos temporariamente em lhe dar crédito e sermos guiados por suas respostas: essa solidariedade com Shelly é crucial para o resto da peça. Portanto, os elementos nostálgicos no cenário deveriam ser engraçados, transmitindo a característica super-realista que aumenta a tensão entre a verdade da memória e a fraudulência da sentimentalidade.

Em Buried Child, espigas de milho são debulhadas e amontoadas em Dodge, e mais tarde Tilden carrega uma criança morta no palco, 'a real' criança enterrada. Quando Arena Stage produziu Buried Child na primavera de 1983, Ralph Goings, um dos fotorealistas mais famosos, foi encarregado de fazer a pintura que posteriormente seria transformada na capa do programa da peça. Quando questionado numa entrevista sobre que fatos da peça o ajudaram a direcionar a pintura, ele respondeu:

Eu li e escolhi Buried Child entre várias peças que a companhia estava encenando naquela temporada porque era a mais próxima do tipo de imagem que me interessa. Encontrei várias coisas com as quais me identifico - o cenário rural, a velha casa e o milharal, e logicamente minha favorita imagem relacionada com a classe trabalhadora - a caminhonete. Fui influenciado mais diretamente pelas sugestões visuais da peça e talvez somente subconscientemente pelo conteúdo literário.

O poder das sugestões visuais numa peça de Shepard é tremendo. A imagem visual é central na teatralidade de Shepard e ele já afirmou que está interessado em escrever peças:

[...] através de atitudes derivadas de outras formas tais como a música, pintura, escultura, filme, etc., o tempo todo tendo em mente que eu estou escrevendo para o teatro.

Se levarmos as definições de hiper-realidade de Jean Baudrillard (1991) em consideração: "A simulação de algo que nunca existiu realmente", e de Umberto Eco (1984): "O engano autêntico", é improvável que Sam Shepard, seja totalmente, um super-realista, mas talvez a conexão com as pinturas de algum modo ilumine as peças e nos permita usar o termo 'super-realista' como um adjetivo compatível nas discussões sobre drama contemporâneo.

No primeiro capítulo apresentamos uma breve visão panorâmica da extensa carreira de Sam Shepard com o intuito de familiarizar o leitor com vários aspectos da sua produção dramatúrgica. Passamos agora a situar suas obras dentro do contexto do drama americano moderno estabelecendo posssíveis associações com autores americanos que o precederam e abordando outros aspectos importantes para análise de três das suas peças. 


\section{O Teatro de Sam Shepard e o drama americano moderno}

\subsection{O drama familiar no teatro americano}

As peças familiares de Shepard são aclamadas com certa frequência como um movimento em direção a uma corrente principal do teatro americano. Existem críticos que lastimam essa mudança e aqueles que a acolhem bem. Na forma, as peças são variações do realismo ou naturalismo, além de utilizarem temas e cenários familiares americanos. A ubiquidade do drama familiar no teatro americano é sempre observada pelos críticos e o cenário familiar torna-se a Gestalt contra a qual se discute a psicologia dos personagens como indivíduos, o desenvolvimento do enredo, ou temas além dos familiares. Thomas Scanlon $(1978$, p. 4) escreve sobre a famíllia no palco americano: "American drama in the twentieth century has been strikingly preoccupied with problems of family life. Its most characteristic moments are realistic scenes of family life $[\ldots] "$.

Entre os dramaturgos cujos trabalhos estabeleceram essa característica no início do século vinte no drama americano estão Eugene O'Neill, Tennessee Williams, Lillian Hellman, Thornton Wilder, Arthur Miller e Edward Albee entre outros.

De acordo com John Gassner (1967, p. xv), "Theatre in America... began to accumulate the multifarious elements that make up theatrical history as early as the second half of the seventeenth century". Um desses elementos foi a família. Das 16 peças americanas que Gassner lista e que foram escritas de 1787 até 1916, nove delas incluem personagens relacionados por nascimento ou casamento e as outras quatro estão significativamente preocupadas com namoro ou casamento iminente. Temas familiares de relacionamento ou hereditariedade, entretanto, começam a proliferar no século XX. Enquanto o realismo é o legado do final do século XIX, o drama familiar precede a história teatral nos mitos do panteão grego; Édipo Rei, de certo modo, é um drama familiar. Se incluirmos na nossa definição de drama familiar aquelas peças cuja ação é a luta para formação de uma unidade conjugal, a família agiganta-se ainda mais na história teatral. Sven Armens no seu estudo sobre arquétipos jungianos na literatura dramática explica que:

\footnotetext{
A família como a experenciamos, muito definidamente e concretamente é; como um ponto específico de referência, como aquela parte da nossa existência diária que inclui procriação, nutrição, afeto ou a ausência de funcionamento como a terra embaixo dos nossos pés como a fundação do nosso sentimento. Fundamentar o trabalho artístico nas imagens básicas associadas com a família dá a ele uma concretude transpessoal além da consciência restrita do artista individual e das aberrações pessoais que podem ser criadas a partir das suas impressões únicas. (Archetypes of the Family in Literature, 1966, p. 191)
}

Com o advento da psicologia nas ciências e o realismo da quarta parede no teatro por volta de 1870, a familia tornou-se o cenário ideal.

Encontramos uma das poucas tentativas de explicar a obsessão americana com o drama familiar em Tom Scanlon. Ele localiza a causa no grande movimento de migração americana o qual decepou os laços entre a família nuclear e os grupos maiores de 
parentesco. Esse movimento, agravado pela industrialização, criou um isolamento forçado da família e, consequentemente, fazendo com que ela passe a ser a única unidade social significativa e confiável. Na visão de Scanlon, o conflito dramático é pressuposto na tensão entre os dois modelos de famílias dominantes na cultura americana: a família agrária de segurança na qual a família nuclear pode encontrar um lar sem partir de casa, e a família da liberdade a qual enfatiza a independência e autosuficiência do indivíduo. Ele encara essas condições como exclusivas, afirmando:

\begin{abstract}
O que separa dramaturgos como O'Neill, Miller, e Williams dos produtos dos nossos sonhos de massa sobre a vida familiar tal qual Rip Van Winkle e a novela não são os materiais com os quais lidamos, ou mesmo a eloqüência da linguagem, mas muito mais a perseguição incansável das contradições das imagens culturais. $\mathrm{O}$ artista consciente está disposto ou inspirado a testar essas reivindicações conflituosas, empurrá-las para o seu extremo máximo para definir sua própria relação. Enquanto que o drama familiar popular evita as implicações do seu próprio material. (Family, Drama and American Dreams, 1978, p. 78).
\end{abstract}

O drama familiar popular frequentemente espelhou uma função da família saudável enquanto que outra faceta do teatro dramatizou os inevitáveis conflitos gerados pela família disfuncional.

Não seria surpresa alguma o fato de as famílias disfuncionais povoarem o teatro, pois as condições que definem esse tipo de família estão em harmonia com as expectativas do drama moderno criando o ambiente teatral ideal para os autores. Existe o personagem central, um protagonista, sendo que os outros membros da família encenam papéis coadjuvantes, papéis os quais sujeitam e às vezes apagam as personalidades individuais dos atores. O conflito frequentemente inerente e violento nestas famílias precipita crise depois de crise sem atingir uma resolução nem na geração presente nem nas seguintes. Os membros familiares carregam seu destino, suas maldições em qualquer fuga que eles busquem assim como personagens teatrais o fizeram desde Sófocles até Shepard (e depois dele).

Tom Dardis (1989, p. 4) delineia a tradição na comunidade literária, afirmando que:

Durante muitos anos, muitos dos nossos melhores artistas aceitaram a conexão [entre álcool e criatividade]. Na realidade, muitos afirmaram que tiveram pouca escolha além de beber, e muito, se quisessem atuar no seu ponto máximo. (The Thirsty Muse: Alcohol and the American Writer, 1989, p. 4)

Durante sua investigação Thomas Gilmore apresenta um aspecto similar:

Se duas das características do modernismo são uma insatisfação radical com a realidade do lugar comum e uma consequente tentativa de sabotar a realidade convencional alterando os estados de consciência, onde os desafios fundamentais para ruptura desses estados oferecidos pelo beber intensamente pode parecer desejável do ponto de vista moderno... Poderíamos afirmar que o início do modernismo é marcado pelo desejo de alterar a consciência ou percepção através do uso do ópio, então o modernismo mais recente tem esse desejo similar utilizando o álcool. (Equivocal Spirits: Alcoholism and Drinking in Twentieth-Century Literature, 1987, p. 172) 
Críticos, como membros da comunidade criativa, parecem frequentemente aceitar tanto escritores como personagens que bebem como perseguidores de verdades mais elevadas ou de introspecção espiritual - em 'vino veritas'.

\subsection{Família e Sociedade}

No drama americano peças a respeito da família são frequentes e alguns dos maiores dramaturgos são reconhecidos por peças que estão centradas na vida familiar. O'Neill, Miller, e Shepard não são exceções, com trabalhos que expressam um interesse profundo pelo papel da família na sociedade americana.

É interessante notar que enquanto podemos traçar paralelos entre Long Day's Journey into the Night (O'NEILL, 1987) e Death of a Salesman, (MILLER, 1976), por exemplo em termos de forma dramática, as peças de Shepard têm um realismo insólito, inusitado, inovador em direção própria. As duas primeiras peças familiares são consideradas mais 'tradicionais' com tendência a tradição ibseniana. As peças de Shepard como Buried Child, Fool for Love e Curse of a Starving Class, por outro lado contêm elementos "estranhadores", "perturbadores", em especial as imagens brutais que Shepard insere em suas peças - como a do carneiro sangrento, ou a do trabalho ensopado em urina - de resto, passada em ambiente doméstico familiar, cotidiano além do caráter monológico dos conflitos dramáticos em cena - os personagens dão vazão a núcleos traumáticos sem levar o outro em consideração ou sem atingir o outro efetivamente. Seu drama é permeado por um número de inconsistências e levanta mais questões do que respostas. A estranheza e novidade de que se está falando é da forma. Mergulhar numa peça de Shepard é como pisar num território confuso e não familiar. A necessidade de fugir dessa atmosfera surrealista logo surge; e mesmo assim existe algo de intrigante sobre seus personagens grotescos e enredos estranhos. Você é atraído para o "universo shepardiano" sem mesmo compreender as razões. Em alguns aspectos da vida familiar, Buried Child e Fool for Love emergem como opostos diretos de Long Day's Journey into the Night e Death of Salesman.

As quatro peças retratam a mesma estrutura familiar: mãe, pai e dois irmãos em dois períodos diferentes do século 20. Elas também descrevem uma variedade de famílias, abrangendo o inicio até o final do século 20. Os Tyrones em Long Day's Journey into the night são um grupo rico e refinado e a peça se passa em 1912 na Nova Inglaterra. Death of a Salesman se passa no Brooklyn depois da Grande Depressão e da $2^{\text {a }}$ Guerra Mundial e retrata uma família tradicional da classe média. Buried Child e True West se passam numa data mais recente, no final dos anos 70 e no inicio dos anos 80 contando as histórias de famílias em Illinóis e Califórnia respectivamente. São muitas as afinidades temáticas entre essas peças e todas elas têm famílias em crise no foco, o que vem justificar a aproximação entre esses dramaturgos. Importante também mostrar as diferenças que este material assume, reflexo de mudanças históricas e de recortes específicos. Existem diferenças de linguagem dramática, forma dramatúrgica, ou seja, uso do diálogo, dos conflitos, da construção simbólica. Encontramos um substrato realista comum, mas ênfases específicas: mais psicológica em O'Neill, mais mítica talvez, mais cruamente metafórica em Shepard, por exemplo, contaminada pelo imaginário pop e de cultura de massas.

Alguns aspectos da família podem ser vistos como arquetípicos, posicionados fora do tempo e do espaço. Partilho da opinião de Shepard de que tudo pode ser rastreado na 
família: "O que não tem a ver com a família? Não há nada, se você entende o que eu quero dizer? Até mesmo uma história de amor está relacionada à família. Crime tem a ver com a família. Todos nós saímos um do outro - todos nascem de uma mãe e de um pai, e depois você se torna um pai. É um ciclo sem fim" (em BIGSBY, 1985, p. 21). Questões familiares são intensamente pessoais e ainda assim poderosamente universais. Essas quatro peças mencionadas no parágrafo anterior sondam profundamente a psique americana e exploram a herança cultural da nação, além de exercerem um forte apelo nas pessoas pelo mundo todo. Todos são moldados de alguma maneira pelas famílias as quais pertencem; permanece enraizado na nossa experiência, na nossa identidade, na nossa personalidade, como Miller argumenta: "Nós - todos nós - temos um papel antecedendo todos os outros: somos filhos, filhas, irmãs, irmãos [...] Os conceitos de Pai, Mãe, e os outros foram recebidos por nós antes da época em que estávamos conscientes de nós mesmos como "eus"” ("The family...", p. 81). Papéis familiares são frequentemente difíceis de escapar e geralmente permanentes, e a tentativa de distanciar-se da família geralmente falha. De acordo com Shepard, estamos "intimamente, inevitavelmente e inteiramente conectados a quem nos trouxe ao mundo" (em ROUDANÉ, "Shepard on ...”, p. 68)

O estudo de Tom Scanlon, Family, Drama, and American Dreams (1978), fornece uma pesquisa histórica e sociológica da mudança do papel da família descrito por alguns dramaturgos Americanos. O autor concentra sua atenção em O'Neill, Miller e Tennessee Williams. O trabalho de Thaddeus Wakefield, The Family in Twentieth Century American Drama (2003) aplica uma abordagem marxista e explora maneiras nas quais a cultura capitalista dos Estados Unidos afeta a família. De acordo com o autor, a família americana é valorizada em termos monetários e é meramente uma mercadoria dentro da cultura americana de consumo. Ele escreveu um breve estudo comentando catorze peças familiares americanas.

A posição que a família detém dentro da sociedade tornou-se uma área de debate considerável dentro dos Estados Unidos. É muito difundida a crença tradicional que a família é a espinha dorsal, a fundação, da cultura e da sociedade americana e que a cultura popular tenta projetar uma imagem de uma família americana idealizada e feliz. Muitos sociólogos concordam que a família americana sofreu um processo profundo de mudança durante os séculos 19 e 20. Historicamente, a família nuclear tem sido a estrutura familiar predominante nos Estados Unidos. A revolução industrial e tecnológica provocou uma grande mudança no papel da família na sociedade americana. Os sociólogos contemporâneos frequentemente mencionam a fragmentação da família nuclear. Na visão de Talcott Parsons, as necessidades da família moderna são encontradas fora do meio familiar, quando anteriormente elas eram encontradas pela própria família. Essa teoria apresentada em Family, Socialization and Interaction Process (1995) coincide com os cenários históricos de duas peças: Long Day's Journey into the Night e Death of a Salesman.

A relação entre o público e o privado é focada nas peças familiares de O’Neill, Miller e Shepard. A sociedade é uma parte inseparável de vida familiar e a família é um componente central da sociedade, como a citação inicial de Miller serve para ilustrar: "A sociedade está dentro do homem e o homem dentro da sociedade [...] O peixe está dentro da água e a água está dentro do peixe" ("The Shadows...", p. 39). Talcott Parsons (1974, p. 19) desaprova a ideia de categorizar a família "como uma pequena sociedade nela mesma", mas insiste que ela deva ser vista como "um subsistema diferenciado da 
sociedade", e, portanto sugere que o papel privado de uma pessoa tem como premissa o seu papel público. As quatro peças selecionadas estendem-se do seu papel privado para o seu papel público; elas podem ser consideradas dramas individuais e sociais ao mesmo tempo. Na visão de Miller, as melhores peças são aquelas nas quais questões de identidade levantadas vão muito além do nível pessoal; alienação pessoal e nacional parecem andar de mãos dadas. O’Neill, Miller e Shepard são reconhecidos por sua crítica persistente da sociedade americana e seu desejo de acordar uma consciência social nos seus espectadores. Essa sociedade descrita por eles parece estar numa queda livre moral, e eles atacam o que eles consideram a causa, o sistema de valor tradicional sobre o qual os Estados Unidos foi fundado.

A desintegração da família americana descrita em Long Day's Journey into the Night, Death of a Salesman, Buried Child e Fool for Love é transparente. Harold Bloom (1989, p. viii) afirma que Long Day's Journey into the Night retrata "a realidade do pesadelo que pode afligir a vida da família americana [...] O desamparo do amor familiar a sustentar, sem mencionar curar, as feridas do casamento, paternidade, filiação" (p. 115). As quatro peças mencionadas oferecem uma visão sombria da dinâmica complicada das famílias americanas. A pergunta de Shelley em Buried Child - "What's happened to this family anyway?" (p. 112) - toca na essência desse tópico. Não é difícil partilhar da reação chocada de Shelley e querer responder as questões que ela levanta. A idéia de que pressões do mundo exterior entram no domínio familiar e contribuem para desintegração da família americana está latente. Podemos perceber maneiras nas quais a industrialização, o capitalismo, o consumismo e a modernização da economia ocidental afetam o papel da família dentro da sociedade americana. Para assegurar o mito do sonho americano, porém inatingível, a vida familiar paga seu preço. O tema da família disfuncional relaciona-se com os valores incorporados na sociedade; a família está se desmantelando de dentro para fora por sua fidelidade aos valores públicos.

As tensões que caracterizam o relacionamento entre pais e filhos são focadas nas peças e dessa relação surge a erosão da família inteira. Isso demonstra que uma sociedade dirigida pelo sucesso combinado com idéias de masculinidade contamina $o$ relacionamento entre pais e filhos, além de poder incitar a rivalidade entre irmãos.

\subsection{O Legado do Pai e o Sofrimento do Filho}

Nos Estados Unidos como em outros lugares, as vidas de homens estão estruturadas em torno de idéias de masculinidade que em algum grau estão relacionadas a crenças patriarcais. Historicamente, o papel do homem estava ancorado na esfera pública. De acordo com Talcott Parsons, o status da família americana do século 20 é determinado pelo nível do emprego que o "marido-pai” detém e a renda que ele ganha (p.13). É esperado dos homens que eles estejam comprometidos com seu papel público e preferivelmente a profissão de um homem deveria ser motivo de orgulho. Espera-se do homem do século 20 que ele devote sua vida a sua esposa e filhos, primeiramente através da sua função de provedor principal dentro reino familiar, mas também através da educação, ou socialização dos filhos. A influência paterna é particularmente evidente na construção da identidade masculina. O homem americano do século 20 está indubitavelmente carregado de um grande número de expectativas e pode sentir uma dupla pressão; é esperado dele que seja bem sucedido nos seus papéis tanto na arena pública quanto privada. Não surpreendentemente, o papel público e privado às vezes são conflitantes um com o outro. As idéias sobre masculinidade construídas socialmente 
permeiam as relações pai e filho e servem para definir e moldar até mesmo a mais pessoal de suas interações.

Os personagens das quatro peças estão fortemente ligados ao tempo em que eles vivem. Como Brenda Murphy menciona "cada membro da família Loman está sob pressão para comportar-se de uma maneira socialmente predeterminada independentemente do que eles pessoalmente querem fazer" (p. 126). As vidas de Willy Loman, James Tyrone, Dodge e The Old Man - os pais nas peças - estão estruturadas e controladas por definições de masculinidade sugeridas pela sociedade capitalista patriarcal. Essas peças lidam com a luta do homem para confrontar a sociedade e estabelecer uma posição respeitável na esfera pública. As idéias patriarcais e expectativas sociais são passadas de geração para geração: de pais para filhos, Em Long Day's Journey into the Night e Death of a Salesman, o pai nutre grandes expectativas para seu filho, o que se torna uma fonte de conflito profunda. Nas duas peças de Shepard, os pais não utilizavam sua autoridade patriarcal. Dodge e The Old Man podem ser considerados opostos de Tyrone e Willy. As quatro peças mostram círculos intermináveis de desespero masculino; os desafios e erros patriarcais são repetidos pelos filhos. Ancestralidade pode ser interpretada como uma maldição; uma conduta masculina auto-destrutiva que se repete de uma geração para a próxima.

O paralelo entre a vida de O'Neill e seus trabalhos dramáticos são surpreendentes. Long Day's Journey into the Night poderia ter sido uma tentativa de capturar a essência da sua vida familiar e do seu próprio eu. A estrutura do lar dos Tyrone e a tensão entre seus membros lembram em certa dimensão a própria família de O'Neill. Seus pais são mostrados através de Mary e James Tyrone; Jamie, o irmão mais velho de O'Neill; e o irmão mais jovem na peça, Edmund, seria uma projeção imaginativa do próprio O’Neill. Transformar sua própria experiência em drama envolveu uma exposição íntima e pessoal que fez O'Neill requisitar que Long Day's Journey into the Night fosse apresentada para o público vinte e cinco anos após a sua morte. Sua esposa Carlotta para quem a peça foi dedicada - decidiu apressar a publicação e a peça veio a público três anos após a morte de O'Neill. Na dedicatória, O'Neill afirma que Long Day's Journey into the Night é "uma peça sobre velhas mágoas, escrita em lágrimas e sangue" e "finalmente reflete o desejo de enfrentar seus mortos". O'Neill teve muitas dificuldades para escapar das suas origens, como seu biógrafo, Louis Sheaffer, argumenta: "O'Neill, claramente, nunca 'deixou' seus pais. Um filho eterno, para sempre assombrado pelo passado, ele era obcecado com o tópico de relações familiares, particularmente entre pais e filhos" (Son and Artist, p. 506). Beyond the Horizon (1918), a qual ganhou um Pulitzer em 1920, conta a história de um pai que renega seu filho. Desire Under the Elms (1924) é o retrato de uma relação turbulenta entre Ephraim Cabot e seus três filhos. Ah, Wilderness! (1933) é a única comédia de O’Neill entre tantas tragédias e demonstra o quanto ele desejava viver a juventude e a família. Nat Miller é bem o oposto de James Tyrone em Long Day's Journey into the Night ao ficarem mais velhos, O'Neill e seu irmão consideravam as exigências do pai como uma violação da sua liberdade como indivíduos. Ah, Wilderness! pode ser considerada como uma versão alegre e despreocupada da sombria Long Day's Journey into the Night.

A maioria das peças de Shepard explora o conflito entre pais e filhos. O pai permanece um personagem crucial nas peças de Shepard. Em The Late Henry Moss (2000), ele retrata o grande impacto que a morte do pai tem sobre o filho, e de algumas maneiras nos faz lembrar uma de suas peças anteriores, The Holy Ghostly (1970), na qual um 
filho tenta escapar do legado do seu falecido pai em Motel Chronicles (1982), que pode ser considerado um testemunho autobiográfico, Shepard fala da sua própria vida, desde sua infância em Illinóis até a sua vida adulta na área rural da Califórnia. As similaridades entre a descrição dos avós de Shepard em Motel Chronicles e Dodge e Halie em Buried Child são inconfundíveis: 'My grandpa sits exactly as he's always sat - in a hole of his sofa wrapped in crocheted blankets facing the TV. He's a skeleton now [...] My grandmother has great ears" (p. 45-46). "My father lives alone on the desert. He says he doesn't fit with people" (p. 55). O pai ausente em Fool for Love pode ter sido baseado no pai de Shepard, que emocionalmente abalado após ter trabalhado como piloto de bombardeio durante a Segunda Guerra Mundial abandonava esposa e filhos para viver uma vida solitária no deserto. Em 1963, então com vinte anos, Samuel Shepard Rogers decidiu retirar seu último nome, o qual ele partilhava com o pai. Simbolicamente é como se Shepard tentasse romper com sua linhagem paterna. Em Seven Plays (1981) lemos na dedicatória: "For my father, Sam". Shepard afirmou que o conflito entre ele e o pai continuou após a sua morte: "My relationship with him is the same. Exactly the same. It's a relationship of absolute unknowing. I never knew him, although he was around all the time. There's no point in dwelling on it. I mean, my relationship with him now is exactly the same as when he was alive. It's just as mysterious". Aparentemente no caso de Shepard, a batalha entre o pai e o filho é interminável, capaz até mesmo de transcender a morte. Nos trabalhos de Shepard existe um vínculo entre pai e filho que parece que nunca vai ser quebrado. $O$ drama de Shepard torna-se uma tentativa de confrontar tópicos familiares problemáticos: "I've been trying to escape myself ever since I left home [...] and I realize now that I have to face things, I can't run forever" (em BOTTOMS, 1998, p. 154).

As palavras de Miller sobre a peça The Man Who Had All the Luck (1944), "in the writing of the father-son relationship and the son's search for his relatedness there was a fullness of feeling I had never felt before; a crescendo was struck with a force I could almost touch" (em Martin, p. 126). Em All My Sons (1947), a admiração de Chris Keller pelo pai termina de maneira brutal quando ele descobre a traição; em The Price (1968) o pai é um personagem decisivo apesar de somente existir na memória dos dois filhos, que se reaproximaram devido a sua morte. "In all of Miller's major plays, the prime authority and guidance of the father is of primary importance" (em Roudané, Conversations [...], p. 44). Assim como O'Neill e Shepard, Miller confirmou que suas peças contem elementos autobiográficos: "The plays are my autobiography [...] I'm in all of them" (em Bigsby, "Introduction", p. 1). Ao considerarmos Death of a Salesman já não encontramos fontes para traçar esse tipo de paralelismo. Miller declarou que ele partilhava uma relação próxima com seu pai e que nenhuma de suas peças refletia diretamente sobre os dois (ROUDANÉ, 2002, p. 89). Miller indica um certo contraste entre Willy Loman e seu próprio pai: "The reason why I was able to write about the father-son relationship was because it had a mythical quality to me. If I had ever thought I was writing about my father, I suppose I never could have done it. My father is, literally, a much more realistic guy than Willy Loman, and much more successful as a personality" (ibidem, p. 90). Quando o negócio do seu pai desmoronou na grande depressão americana de 1930, a família foi forçada a mudar-se para uma pequena casa no Brooklyn, a qual pode ter servido de modelo para residência dos Loman em Death of a Salesman. O impacto da depressão na família de Miller parece ter causado um pouco de tensão entre pai e filho. Na sua autobiografia, Timebends: A Life (1987) ele menciona alguns sentimentos negativos em relação ao seu pai: "I had two fathers, the real one and 
the metaphoric, and the latter I resented because he did not know how to win out over the general collapse" (p. 112). Aparentemente, o fracasso do pai em lidar com a crise financeira incitou-o a vê-lo em termos ambíguos.

\title{
2.4 Idéias Patriarcais de Masculinidade
}

As idéias dominantes sobre masculinidade no século vinte nos Estados Unidos referemse a certas qualidades, ou características associadas ao sexo masculino como, por exemplo: poder, força e domínio. Esperava-se do homem viver de acordo com essas normas. De acordo com Halie em Buried Child, a "whole man" (p. 124) deveria ser "heroic, brave, strong, and very intelligent" (p. 73).

De acordo com o estudo de Carla J. McDonough (1997, p. 47), Staging Masculinity: Male Identity in Contemporary American Drama: existem dois ideais conflitantes de masculinidade na sociedade americana: "the ideal of masculine success" e o "frontier ideal of masculinity". Enquanto que o primeiro representa homens que mantêm empregos respeitáveis e permanecem participantes ativos da vida pública, os últimos podem ser compreendidos como homens que buscam a vida aventureira de 'cowboys' e pioneiros. Murphy comenta:

\begin{abstract}
A sociedade americana do século XX parece promover uma variedade de funções para a qual os homens podem querer aspirar. Enquanto na sociedade por um lado, aplaude o homem que se casa, tem filhos, e lhes fornece uma boa casa e tudo o que possa desejar, por outro lado, a sociedade também exibe um enorme respeito para com figuras que representam nenhuma dessas qualidades de confiança (p. 142).
\end{abstract}

Parece que o homem americano do século vinte foi pego entre dois ideais contraditórios de masculinidade: o aventureiro morador da imensidão selvagem americana e o homem de negócios urbanizado. Nos dois ambientes era esperado que o homem alcançasse o sucesso e estivesse em controle do meio ambiente. Essas duas imagens conflitantes de masculinidade podem ter se originado de uma mudança sócio-econômica nos Estados Unidos. No final do século dezenove, à medida que a economia americana organiza-se nas linhas capitalistas e industriais, sentiu-se nos Estados Unidos a emergência da urbanização, a fronteira americana finalmente desapareceu. Como resultado, "the pioneer image of the father who would rise to fame and fortune through selfdetermination was giving way to the image of the company man" (ROSEFELDT, 1995, p. 39).

O desaparecimento da fronteira americana incentivou uma grande mudança na percepção dos homens da sua identidade de gênero, como McDonough (1997, p. 36) observa: "American manhood faced a crisis as the frontier gave way to urban sprawl". O romantizar do grande oeste selvagem - representando individualismo rude, liberdade e orgulho masculino - ainda permanece enraizado na cultura americana. A nostalgia em relação a fronteira americana caracteriza por exemplo um certo número de protagonistas masculinos nas peças de Shepard; um fascínio pelo cowboy ecoa nas obras de Shepard: "Cowboys are really interesting to me - these guys, most of them really young, about 16 or 17, who decided they didn't want to have anything to do with the East Coast, with that way of life, and took on this immense country, and didn't have any rules" (em MCDONOUGH, 1997, p. 37). Apesar de muito pouco ter sido revelado sobre The Old 
Man em Fool for Love fica implícito que num ponto da sua vida ele fez parte da sociedade civilizada; entretanto, incapaz de ser bem sucedido ou realizar-se nesse ideal de masculinidade emergente projetado sobre ele por uma sociedade capitalista, ele finalmente escolhe abandonar a vida caótica da cidade, mesmo que isso incluísse o abandono de sua família. Sua rebeldia contra a civilização moderna pode ter se originado a partir de um desejo pelos heróis lendários do 'velho oeste americano' e a liberdade que eles representam. No entanto, isso se tornou um mero ideal no século vinte. Ao escapar para um lugar e um tempo que não mais existem (o oeste selvagem americano) The Old Man se torna um exilado da sociedade americana, como John M. Clum observa em "The Classic Western and Sam Shepard's Family Drama": "In contemporary society, there is no place for a man outside the economic system." 177). Em Buried Child o pai escolheu: "back-to-the-land location" (BOTTOMS, 1998, p. 156). Isso parece ter sido uma decisão deliberada de Dodge: "it wasn't gonna be the city!’(p. 111). Nem Dodge nem The Old Man conseguem alcançar o sucesso masculino e a prosperidade no meio ambiente rural dos Estados Unidos.

Entre as peças americanas modernas, talvez nenhuma outra capture a instabilidade e o dilema da masculinidade americana tradicional melhor do que Death of a Saleman de Arthur Miller. Willy anseia pela vida de aventura, mas está preso em seu papel de homem de empresa. Willy acredita que o mundo de negócio contemporâneo dos Estados Unidos está repleto de oportunidades, quando menciona: "the man who makes an appearance in the business world, the man who creates personal interest, is the man who gets ahead" (p. 33). Depois de encontrar o bem sucedido vendedor, Dave Singleman, Willy convence-se que "selling is the greatest career a man could want" ( $p$. 81). Willy também vê seu próprio pai como a personificação do sucesso masculino, apesar de representar uma ideologia muito diferente da de Singleman. Singleman resume o homem de negócios urbanizado, o pai de Willy é um aventureiro de um lugar selvagem, portanto um herói do passado americano perdido: "at once the untamed man and the westward-bound pioneer, the artisan, the great inventor, and the successful entrepeneur" (Hadomi, p. 53). A idealização vitalícia de Willy pelo pai e por Singleman o deixa dividido entre duas ideologias diferentes . Como McDonough (1997) afirma: "Willy is trapped between competing versions of manhood, and his unwillingness to see the two versions as incompatible leads to his failure and death" (p. 27).

De acordo com o estudo de Scanlon (1978), Family, Drama, and American Dreams, dois modelos de família emergiram: "the family of security"- "urge toward the safety of mutuality" e "the family of freedom" - "the contrary urge for independence and selfhood" (p. 27). Em Death of a Salesman, Willy dá voz ao confinamento da vida familiar quando expressa um dos seus maiores arrependimentos: "Why didn't I go to Alaska with my brother Ben that time! [...] What a mistake! [...] If I had gone with him to Alaska that time, everything would've been totally different" (p. 41, 45). A responsabilidade que Willy tem pelo bem estar familiar o impede de ir atrás de sua necessidade de liberdade pessoal. Ao mesmo tempo, Willy é muito dependente do sentido de segurança que a vida em família representa. A luta para combinar anseios diferentes também está presente em Long Day's Journey into the Night. Tyrone anseia pela companhia de uma mulher e a segurança da vida em família, mas ele também anseia por individualismo. As profissões itinerantes dos dois personagens, um como ator e o outro como caixeiro viajante, podem ser vistas como tentativas de reconciliar necessidades conflitantes por liberdade, de um lado e segurança, do outro. Na verdade, 
a mobilidade dessas profissões assemelha-se à liberdade do aventureiro tradicional americano.

A principal característica de masculinidade nas peças está associada à ideia de patriarcalismo. Dentro do sistema patriarcal do século vinte nos Estados Unidos, Tyrone, Willy, Dodge e The Old Man deveriam ser líderes, tanto dentro como fora da esfera familiar. Espera-se que eles sejam bem sucedidos em termos ocupacionais, os provedores, os chefes de família dos seus respectivos lares, exercendo autoridade sobre suas esposas e filhos. Essas quatro peças descrevem as estratégias dos personagens masculinos para lidar com os dois cenários: o lar e a sociedade. Willy reivindica seu papel de chefe de família na sua casa além de ser o único provedor da família. Sua busca em exercer autoridade absoluta sobre sua esposa e filhos fica clara durante a peça. Entretanto ele não aparece como um patriarca autoritário. Por exemplo, ele tem um nome de garoto, provavelmente o diminutivo para William. Somente em raras ocasiões ele é chamado de "Mr. Loman" (p. 90). Na realidade, Biff refere-se a ele ironicamente como "the boss" (p. 123) e em dois momentos na peça seus filhos o chamam de "scout" (p. 105, 129). Howard Wagner, seu patrão que é bem mais novo que Willy, o chama de "kid" (p. 84). O sobrenome "Loman" é reminiscente de "Low Man", denotando inferioridade e insegurança. A apresentação inicial de Willy, carregando duas malas grandes, imediatamente sugere seu fardo: "his exhaustion is apparent" (p. 12). A fatiga de Willy origina-se de sua falta de realizações profissionais e sua inabilidade de alcançar destaque, riqueza e dinheiro. Willy sabe que para um homem alcançar aceitação na sociedade moderna deve ser ambicioso, trabalhador e preferivelmente, em suas próprias palavras, "accomplish something" (p. 15). Entretanto, Willy mal consegue pagar as contas no final do mês. Como ele não consegue ser um bom provedor ele também fracassa como patriarca.

Em Long Day's Journey into the Night, entretanto, James Tyrone é obviamente o patriarca da família, e o principal portador do nome da família, Ele é o Tyrone, enfatizando seu papel autoritário dentro da família. A descrição inicial de Tyrone feita por O'Neill pode ser contrastada com a descrição de Willy feita por Miller. Tyrone é apresentado como uma versão estereotipada do sexo masculino; forte, orgulhoso e confiante: "About five feet eight, broad-shouldered and deep-chested, he seems taller and slenderer because of his bearing, which has a soldierly quality of head up, chest out, stomach in, shoulders squared" (p. 11). Em muitos aspectos, Tyrone nos faz lembrar do personagem de Tennessee Williams, Big Daddy, em Cat on a Hot Tin Roof (1955) que parece o patriarca encarnado. A psique superior dos homens espelha a sua conduta dominante em relação a suas esposas e filhos. Portanto, o poder e a necessidade de estar no comando parecem caracterizar tanto Tyrone com Big Daddy. Assim como o nome de Big Daddy, "Tyrone" denota poder e força, o nome deriva da palavra grega "Turannos", que se refere a "soberano" ou "rei". No decorrer da peça Tyrone é comparado a um leopardo (p.31) e a um falcão (p. 102) - animais independentes, poderosos e predadores. Considerando que tanto um como outro representam prosperidade financeira, eles são considerados bem sucedidos aos olhos da cultura capitalista dos Estados Unidos. Enquanto o primeiro é um fazendeiro milionário, o último possui uma "property valued at a quarter of a million" (p. 147), e ambos sustentam suas famílias materialmente. Tyrone tem dois funcionários e um chofer, por exemplo.

Dodge em Buried Child representa a antítese do patriarca do século vinte: "I'm an invisible man!" (p.68). O patriarca fracassado dessa peça cuja morte passa despercebida 
é contrastante com o patriarca moribundo de Cat on a Hot Tin Roof o qual está rodeado de familiares preocupados. Dodge está confinado no sofá e é o único personagem em Buried Child que nunca sai do palco, o que enfatiza a falta de necessidade do seu papel público. Ele é caracterizado como um homem frágil: "very thin and sickly looking" (p. 63). De acordo com o próprio Dodge ele é "dependent on the whims of others" (p. 96) e "can't be left alone for a minute!" (p. 79). Alguns dos segredos familiares como incesto e infanticídio arruinaram o senso de masculinidade de Dodge. Ele insiste que sua família havia sido "well-established" (p. 123); e descreve a fazenda como sendo próspera: "producing enough milk to fill Lake Michigan twice over" (p. 123). Depois do nada sua esposa Halie fica grávida e dá a luz a um menino, que seria resultado do incesto entre mãe e filho. A criança marca uma virada no destino da família, e incita uma mudança considerável na percepção de masculinidade de Dodge ao desafiar sua posição de autoridade dentro da família: "It made everything we accomplish look like it was nothin'. Everything was cancelled out by this one mistake. This one weakness" (p. 124). Dodge resolve matar essa criança que ameaça seu poder patriarcal. Entretanto depois de perceber sua incapacidade de controlar a ação do seu filho mais velho, Tilden, e até mesmo a sexualidade da sua própria esposa, Dodge percebe que está desprovido de poder e decide aprisionar-se na própria casa. Como resultado ele evita seu papel de autoridade dentro da esfera pública, coincidindo com o cessar da prosperidade da fazenda: "There hasn't been corn out there since about nineteen thirty-five! That's the last time I planted corn out there!” (p. 69). Os campos inférteis da fazenda refletem a simbólica castração de Dodge como o patriarca. Ironicamente ele comenta: "Persistence, fortitude e determination. Those are the three virtues. You stick with those three and you can't go wrong." (p. 98). Na sua percepção distorcida da realidade Dodge conseguiu transformar seus vícios em virtudes; sua única determinação é escapar da sua situação problemática. E para compensar sua falta de poder ele tenta mandar na esposa e filhos. Entretanto nenhum dos dois demonstra algum sinal de obediência ao derrotado Dodge.

Em Fool for Love, Shepard retrata outro patriarca fracassado, um que abandonou a família. De acordo com McDonough, "as peças de Shepard dos anos 70 e 80 são abundantes de imagens de homens que abandonaram (ou desejam abandonar) suas responsabilidades empregatícias ou familiares em troca da vida absorta e solitária de uma região desértica geralmente o Mojave ${ }^{4}$ ou de uma garrafa de bebida" (p. 38). Em Buried Child, Dodge escapou de tudo com sua garrafa de uísque, e apesar de sempre presente no palco, de alguma maneira ele deixou sua família e o mesmo pode se dizer de The Old Man em Fool for Love que abandonou sua família de uma maneira mais literal do que Dodge. The Old Man nunca está no palco, porém ele é um personagem crucial e de certa maneira dirige a ação da peça. Ele indiretamente exerce um tipo de poder sobre seus dois filhos e é uma grande força em suas vidas, e certamente não é retratado como o pai patriarcal tradicional. Schvey descreve os pais ficcionais de Shepard como "fracos" e "distantes" (p. 13); já de acordo com Megan Williams, o drama de Shepard retrata: "a series of nowhere-men who have willingly abandoned a

\footnotetext{
${ }^{4}$ É o nome dado a parte mais elevada do deserto da Califórnia, sendo que o deserto de Sonora corresponde a sua parte baixa. Esse deserto possui clima bastante hostil e abriga formações geológicas famosas, como o Vale da Morte, com seus leitos de lagos secos e cheios de sal. Nesse deserto também está alocado o maior cemitério de aviões do mundo, que consiste em um depósito onde jatos das empresas aéreas de todo o mundo ficam aguardando para serem desmontados para aproveitamento de seus materiais recicláveis. O deserto tem esse nome devido à grande predominância de cobras Mojave, um tipo de cascavel.
} 
sense of time, place and history [...] Without the ability to ground himself in space and time, man becomes deprived of a sense of his private and public selves" (p. 57-58). Essa afirmação aplica-se ao The Old Man em Fool for Love. O fato de ele permanecer sem nome durante a peça reforça seu status de "nowhere-man" e enfatiza sua ausência de autoridade. $O$ deserto infértil que ele habita sugere um tipo de masculinidade esterilizada. Sem poder tanto na arena pública quanto privada, The Old Man está muito aquém dos ideais patriarcais.

De certa maneira Tyrone, Willy, Dodge e The Old Man estão aprisionados pelas idéias de masculinidade estabelecidas e impostas a eles desde seu nascimento. Enquanto Dodge e The Old Man perceberam sua incapacidade em assumir sua autoridade tanto na esfera pública quanto privada e abandonaram as responsabilidades impostas a eles pela sociedade, Tyrone e Willy fazem tentativas vãs de sustentarem os papéis que esperam que eles preencham.

\subsection{A Cultura do Sucesso Masculino}

Os pais de Long Day's Journey into the Night e Death of a Salesman estão profundamente emaranhados na cultura do sucesso masculino tão incorporado à cultura americana do século vinte. Os Estados Unidos foram de muitas maneiras fundados sobre a crença em trabalho árduo, e o desejo de esforçar-se e ter sucesso são inerentes à psique americana, como as afirmações de Willy ilustram: "A man can't go out the way he came in [...] a man has got to add up to something" (p. 125). Ironicamente, Dodge em Buried Child também parece agarrar-se a uma visão estereotipada de masculinidade: "There's nothing a man can't do. You dream it up and he can do it. Anything" (p. 110). Nos Estados Unidos, sucesso é sinônimo de respeito e prestígio; mais importante, ele representa a ideia de mobilidade social. Tanto Long Day's Journey into the Night quanto Death of a Salesman são caracterizadas por uma fome de sucesso financeiro. Os pais nessas peças estão determinados em se conformar às normas sociais e viver pelo código de uma sociedade capitalista e patriarcal. Tyrone e Willy incorporam a ideia que "capitalism influences a man's ideologies in defining his masculinity" (WAKEFIELD, 2003, p. 23).

Tyrone e Willy têm uma forte ética de trabalho e grande orgulho de suas profissões; na verdade, eles são definidos em relação a suas carreiras profissionais. Miller introduz seu protagonista masculino com as seguintes palavras: "From the right, Willy Loman, the Salesman, enters" (p. 12, grifo do autor). A descrição de Tyrone feita por O’Neill é similar: "The stamp of his profession is unmistakably on him. (...) the actor shows in all his unconscious habits of speech, movement and gesture" (p. 13). Parece que Tyrone e Willy identificam-se em primeiro lugar com seus papéis na sociedade, não com os papéis privados como maridos e pais. Eles são homens ambiciosos que se dedicam a esfera pública, e o pico das suas vidas está relacionado com suas carreiras profissionais. Tyrone agarra-se ao elogio que recebeu: "As I look back on it now, that night was the high spot in my career (...) I made the manager put down his exact words in writing. I kept it in my wallet for years." (p. 153, 155). Death of a Salesman está infestada com referências a um tempo em que as realizações de Willy eram supostamente grandiosas: "in 1928 I had a big year, I averaged a hundred and seventy dollars a week in commissions" (p. 82). 
Acima de tudo, Tyrone e Willy consideram-se homens de negócio importantes ativamente participando do sistema capitalista dos Estados Unidos. Eles adotam a obsessão da cultura americana com a riqueza material, como bem percebemos através do passatempo que Tyrone adota de investir em propriedade e a preocupação de Willy com posses materiais. Eles escolhem adaptar-se a uma sociedade na qual homens são em primeiro lugar valorizados de acordo com as suas realizações públicas e o tamanho das suas contas bancárias. $\mathrm{O}$ medo de Tyrone da pobreza e suas afetações aristocráticas podem ser comparados às lutas de Willy por prosperidade financeira e sua preocupação com os homens de sucesso. Tyrone e Willy acabam incapazes de negociar entre seus papéis públicos e privados, o que os impele a negligenciar suas famílias. No caso desses homens, a busca por sucesso material mostra-se irreconciliável com a expectativa de que eles sejam bem sucedidos como esposos e pais. Na sua fervorosa busca por riqueza e status - a definição americana de sucesso - suas famílias sempre vêm em segundo lugar. Wakefield observa sobre essa sobreposição dos papéis: "America's twentieth century capitalistic society thwarts American fathers attempting to fulfill traditional paternalistic roles" (p. 24). Na verdade, Willy e Tyrone também projetam seu papel público na arena do lar.

A profissão de Willy requer que ele constantemente interprete o papel do talentoso e confiante vendedor. Willy confia na sua habilidade de encenar e ganhar a convicção de outras pessoas. Seu sentido de auto-estima depende da aprovação de outros, e como resultado, ele preocupa-se com sua reputação dentro do mundo público. Na conduta de Willy ecoa a filosofia de negócio de Dale Carnegie: a ideia de conquistar o mundo através do charme e da personalidade. Willy acredita que o sucesso pode ser atingido através da atratividade pessoal, de ser estimado pelos outros: "personality always wins the day" (p. 65) e "be liked and you will never want" (p. 33). Claramente, de acordo com Willy ser popular é sinônimo de ser bem sucedido. Ele constantemente aplica sua filosofia dos negócios com sua família e cria seus filhos à sombra dessa ideologia. Ele diz para Biff e Happy: "America is full of beautiful towns and fine, upstanding people. And they know me, boys, they know me up and down New England (...) I can park my car in any street in New England, and the cops protect it like their own" (p. 31). O vendedor tornou-se uma parte inseparável da identidade de Willy. No decorrer da peça nunca ficamos sabendo que tipo de produto Willy vende. Podemos argumentar que Willy vende a si mesmo. Ele se permite tornar uma mera mercadoria no sistema capitalista. Sua preocupação com o valor de Biff no mundo dos negócios sugere um desejo de vendê-lo no mercado capitalista. Ao fazê-lo, Willly mercantiliza Billy em termos de cultura de consumo na qual os Estados Unidos do século XX é fundado, e ele parece incapaz de olhar além do valor de mercado de Billy. De acordo com Steven R. Centola, Willy "has deceived himself into thinking that the values of the family he cherishes are inextricably linked with the values of the business world in which he works" (p. 27). Willy interpreta o papel de homem de negócios até o derradeiro final; onde ele vende sua vida pelo lucro.

Como ator profissional, Tyrone sabe quando entrar no papel, e ele é repetidamente visto encenando para ele mesmo assim como para outros. A peça é permeada por alusões literárias, em inúmeras ocasiões Tyrone e seus filhos citam filósofos e autores conhecidos. Tyrone é visto "putting on a fake heartiness" (p.68) em frente a Edmund, e mais tarde ele "forces his face into a pleasantly paternal expression" antes de abordar seu filho "with an actor's heartiness" (p. 91). Em várias ocasiões Mary menciona a tendência do marido de trazer sua profissão para casa junto com ele: "He isn't a great 
actor for nothing, is he? (...) I can tell when you're acting!” (p. 124). Ela também afirma que ele sempre "makes such a show of himself" (p. 44). Tyrone confia em suas habilidades teatrais para conseguir lucrativas barganhas vestindo sua máscara de confiança masculina. De acordo com Jamie: "Tyrone puts on an act for every damned fool that comes along" (p. 57). Ele também parece valorizar os filhos em termos capitalistas o que fica evidente quando ele menciona que Jamie não vale o próprio salário (p. 32). Jamie chama a atenção para maneira de seu pai valorizar tudo até mesmo os próprios filhos em termos monetários: "If Edmund was a lousy acre of land you wanted, the sky would be the limit" (p. 31). Wakefield comenta: "In the twentieth century American society, family members do not value each other through intrinsic standards but rather are objectified and commodified by economic standards" (p. 2). Essa afirmação aplica-se tanto a Long Day's Journey into the Night quanto a Death of a Salesman.

A natureza performativa da masculinidade serve para caracterizar relações familiares em Buried Child também, retratada através dos personagens Dodge e Bradley. É importante observar que as máscaras de representação teatral desses homens diferem das de Tyrone e Willy, que vestem as máscaras do sucesso masculino. Entretanto nas quatro peças as máscaras originam-se de um sentimento de inadequação masculina e podem ser vistas como tentativas de ganhar dominação masculina. $\mathrm{O}$ pai e o filho de Buried Child estão completamente conscientes da obsessão da cultura americana com a "importance in a man" (p. 105), como Bradley a coloca. Incapaz de atender às expectativas da sociedade em relação ao sucesso, eles parecem recorrer a um comportamento agressivo para poder provar sua masculinidade. De acordo com Shepard, "there's some hidden, deeply rooted thing in the Anglo-male American that has to do with inferiority, that has to do with not being a man, and always, continually having to act out some idea of manhood that is violent" (em MCDONOUGH, 1997, p. 35). Por exemplo, a linguagem usada por Dodge e Bradley pode ser caracterizada como extremamente agressiva. Logo de início, o pai ameaça matar o filho (p. 67) e é impressionante testemunhar que a grande maioria de suas falas termina com pontos de exclamação, o que serve para enfatizar a conduta agressiva de Dodge. Bradley também tenta compensar sua falta de poder masculino através da sua atitude violenta, a qual é demonstrada na sua entrada na peça: "Sonuvabitch! Sonuvagoddamnbitch!" (p. 81). Sua aparência física imponente pode ser vista como uma tentativa de provar sua dominação masculina e compensar por sua perna amputada: "His arms and shoulders are extremely

powerful and muscular" (p. 82). Quase no final do Ato II, Bradley enfia seus dedos brutalmente na boca de Shelly - um estupro simbólico - numa demonstração da sua superioridade masculina. Entretanto, como Ann C. Hall (1993, p. 99) argumenta: "Bradley's patriarchal power is questioned at the very moment He is trying to prove his potency".

\subsection{A busca do pai por autoridade e o primogênito}

Dentro da sociedade patriarcal, autoridade, linhagem e descendência estão colocadas em primeiro lugar no homem. Somando-se a isso, o filho primogênito manteve historicamente uma posição privilegiada dentro da linhagem patriarcal. Em narrativas bíblicas, o filho primogênito era nomeado herdeiro do patrimônio do pai. Após a morte do patriarca, propriedade e títulos eram passados para o filho mais velho. Indubitavelmente, o pai esperava que o seu primogênito fosse digno da sua herança, e como resultado, ele assumia uma responsabilidade e compromisso especial em relação 
ao filho. Geralmente o pai tinha uma esperança subjacente de que o filho se tornaria uma fonte de orgulho e seguiria seus passos, por exemplo, em termos de ocupação. Essa doutrina aplica-se aos pais de Long Day's Journey into the Night e Death of a Salesman. Em ambas as peças o desejo de exercer autoridade paternal é particularmente perceptível na relação entre o pai e o primogênito. Em Buried Child e Fool for Love, por outro lado, as relações entre pai e filho são totalmente afastadas e a autoridade patriarcal de Dodge e The Old Man pode ser questionada. Paternidade aparentemente é um papel que nenhum deles sabe como interpretar; consequentemente, eles parecem não ter expectativas ou ambições para seus filhos.

O favoritismo patriarcal do pai em relação ao filho primogênito é uma característica marcante em Long Day's Journey into the Night e Death of a Salesman. Uma tradição comum dentro da cultura patriarcal é dar o mesmo nome do pai ao primogênito. Em Long Day's Journey into the Night Tyrone deu seu nome - James - ao primogênito. Nas direções iniciais de palco escritas por O'Neill, Jamie, aparece como um reflexo do pai: "He hás his father's broad-shouldered, deep-chested physique" (p. 19). Parece que Tyrone identifica-se mais com a força e o físico de Jamie do que com a saúde frágil de Edmund. Ele parece distanciar-se do seu filho mais novo. Ele diz a Jamie: "You're a healthy hulk like me [...] but [Edmund has] always been a bundle of nerves like his mother" (p. 34). Willy identifica-se com o filho que expressa as qualidades masculinas que ele tanto estima: seu primogênito, Biff. Willy admira tudo que Biff realiza; suas habilidades atléticas, sua boa aparência, e sua popularidade entre os amigos. Willy compara Biff a heróis da mitologia Grega: Adônis e Hércules (p. 33, 68). De acordo com Willy, Biff é: "like a god" e uma estrela magnificente que "can never really fade away" (p. 68). Na opinião de Anne Stavney, Willy atribui qualidades divinas a Biff: "In Willy's eyes Biff is superhuman, sanctified, haloed, divine. One may assume that Willy favors Biff because he embodies all the qualities that he himself has craved his entire life. In the eyes of their fathers, Jamie and Biff represent the prospects of success; as a result, Tyronne and Willy place very high expectations on them." (p. 57) Até mesmo em Buried Child, Halie verbaliza a ideia que seu filho primogênito possui uma posição especial: "Tilden is the oldest. I always thought he'd be the one to take responsibility" (p. 72)

O conflito central em Long Day's Journey into the Night e Death of a Salesman é claramente entre o pai e o primogênito. Tyrone e Willy esperam que seus filhos interpretem de bom grado os mesmos papéis públicos de seus pais. Ambos os pais tentam impor seus próprios ideais e ambições aos filhos, e expressam o desejo de que eles sigam seus passos na área profissional. Enquanto Tyrone quer que Jamie o suceda como ator, Willy quer que Biff siga a carreira de vendedor, e ambos os pais esperam que seus filhos ganhem reconhecimento e atinjam sucesso comercial. Os ideais dos pais de proeminência e sonhos de grandeza são transferidos para os filhos. Ao forçar suas próprias filosofias de vida aos filhos, Tyrone e Willy expressam o desejo que os mesmos adotem as identidades dos pais, e durante as peças, eles lutam para criar Jamie e Biff as suas próprias imagens. Eles nutrem esperanças não só para eles, mas para as perspectivas futuras dos próprios filhos. Em ambas as peças, a busca do pai por autoridade paternal é incompatível com o desejo do filho por individualidade. Enquanto Tyrone e Willy lutam para controlar as escolhas de vida dos filhos, Jamie e Biff anseiam em abraçar sua própria individualidade e liberdade de espírito. Ambos questionam a autoridade do pai, mas ainda assim lutam para libertar-se do domínio paternal. Quando 
eles ficam aquém dos ideais dos pais, eles se tornam uma fonte de desapontamento, o que cria profundas tensões dentro do domínio familiar.

Em ambas as peças a frustração do pai com o filho caminha de mãos dadas com a grande ambição de que ele seja bem sucedido, além do pai expressar ressentimento pela falta de realizações do filho. Na realidade, a turbulência entre pai e filho em Long Day's Journey into the Night é indicada antes mesmo dos dois se encontrarem no palco. Tanto Tyrone como Willy reclamam sobre seus filhos para suas esposas e mostram seu claro desapontamento sobre o fato de eles não estarem estabelecidos ainda. Willy fala para Linda: "not finding yourself at the age of thirty-four is a disgrace!" (p. 16). Tyrone conversa com Mary: "He'd better start soon then. He's nearly thirty-four". (p. 18). Jamie fracassa em partilhar o nome com o pai, e passa a ser o principal alvo de ataque verbal de Tyrone. Seu pai se refere a ele como: "a lazy lunk" (p. 32) que não tem ambição na vida exceto por "loafing in barrooms" (p. 32). Similarmente, Willy critica Biff praticamente durante toda a peça Death of a Salesman e afirma: "Biff is a lazy bum!” (p. 16). Ele desesperadamente o questiona: "Don't you want to be anything?" (p. 112). Tyrone e Willy sabem que a menos que seus filhos tenham uma posição respeitável no mundo ocupacional, estarão muito aquém dos ideais masculinos de sucesso do século XX. Ironicamente, em Buried Child, o preconceito estereotipado de masculinidade é comunicado através de um personagem feminino, Halie. Ela fica estarrecida com a falta de realizações que caracterizam seu marido e filhos: "What's happened to the men of this family! Where are the men!" (p. 124). Horrorizada pelo distanciamento da arena pública dos filhos e do marido, Halie tem uma necessidade desesperada de comemorar o sucesso masculino do único membro da família que vai de encontro as suas expectativas, Ansel. Ela quer edificar uma estatua que simbolize o estereótipo do masculino heróico: "A big, tall statue with a basketball in one hand and a rifle in the other" (p. 73). Entretanto, parece que a estatura de Ansel como um homem de sucesso é somente um produto da imaginação de Halie. Primeiramente, a morte dele em um quarto de motel foi longe de ser heróica; Bradley até alega que Ansel nunca jogou basquete (p. 116). Ainda assim Halie insiste que Ansel: "could've earned lots of Money. Lots and lots of money (...) Ansel could've been a great man. One of the greatest" (p. 73). Como Ansel nunca está presente no palco, somente existe vividamente na mente de sua mãe, parece que Halie relata com exagero sua força masculina. Como David DeRose observa: "Halie's tales of Ansel seem almost a fantasy she hás formulated and that she trots out from time to time as a substitute for the disappointment of her real sons" (p. 106). As attitudes ilusórias de Halie em relação a Ansel podem ser comparadas à recusa de Tyrone e de Willy em reconhecer o desinteresse de seus filhos pelo sucesso. Ambos os pais se apegam à esperança de que seus filhos serão bem sucedidos. Tyrone diz para Jamie: "You're Young yet. You could still make your Mark. You had the talent to become a fine actor! You have it still. You're my son!” (p. 33). Willy tenta tranquilizar-se: "Certain men just don't get started till later in life. Like Thomas Edinson, I think. Or B. F. Goodrich. One of them was deaf (...) I'll put my money on Biff" (p. 18).

O conflito entre pai e filho em Death of a Salesman pode originar-se das idéias conflituosas de masculinidade nas quais Biff se vê enredado; parece que Biff herda a confusão de seu pai. Biff é um sonhador, um aventureiro, e nos faz lembrar o seu avô até certo ponto. Sua preferência pelo modo de vida de seu avô entra diretamente em conflito com as expectativas que ele enfrenta como um membro de uma sociedade urbanizada; como resultado, ele torna-se como o pai - dividido entre dois extremos. Ele 
lamenta: "I don't know what I am supposed to want" (p. 22) A afirmação de Billy perfeitamente captura o relacionamento desintegrado entre a sociedade e o indivíduo, no qual forças exteriores colidem com a busca individual por autonomia. Apesar de Biff repetir a luta pessoal de seu pai, Willy não parece mostrar nenhuma consideração pela desorientação do filho. Ele espera que Biff siga a convenção e atinja o sucesso profissional ou ao menos construa uma fachada de desempenho masculino. Para o grande decepção de seu pai, Biff declara: "I don't fit in business" (p. 60). Ele prefere trabalho manual e deseja trabalhar num ambiente exterior "with his shirt off" (p. 22). Entretanto, Willy considera esse tipo de trabalho de segunda e diz para seu filho: "Even your grandfather was better than a carpenter" (p. 61). Biff está consciente de que fracassou em atingir os ideais que seu pai idealizou para ele, e de alguma maneira ele se sente obrigado a dedicar seu futuro no mundo dos negócios de seu pai. Podemos concluir que a crença de Biff em si mesmo é minada pelo desejo do pai de que ele seja um sucesso: "I've always made a point of not wasting my life, and everytime I come back here I know that all I've done is waste my life" (p. 22, 23). Dessa maneira, Willy constantemente relembra Biff do seu fracasso.

Em Long Day's Journey into the Night, a relação entre o pai e o primogênito pode ser caracterizada por uma luta constante por domínio. Tyrone continuamente reage à mentalidade de Jamie e o ataca verbalmente em inúmeras ocasiões. Na realidade ele até discute com Jamie até mesmo quando ele não está presente: "The padlock is all scratched. That drunken loafer has tried to pick the lock with a piece of wire, the way he's done before. With satisfaction, as if this was a perpetual battle of wits with his elder son. But I've fooled him this time" (p. 124). As incompatíveis filosofias de vida entre pai e filho são indicadas pelas estantes contrastantes mencionadas no inicio da descrição do palco. A estante que representa Tyrone contém obras clássicas e históricas, a de Jamie (e Edmund) contém literatura de revolta, o que serve para sinalizar as necessidades dos filhos em se rebelar contra o pai. Tyrone não só desaprova como condena o gosto literário dos filhos.

Jamie desenvolveu certas estratégias de resistência na tentativa de evitar discussões com o pai. Ele ignora os seus comentários encolhendo os ombros, permanecendo em silêncio e não iniciando uma nova discussão. Tyrone fica enraivecido, mas Jamie repete esse padrão inúmeras vezes. Jamie parece saber que nada do que possa fazer ou dizer irá reverter o ressentimento que seu pai sente por ele. Ao recorrer à passividade e não confrontar o pai, Jamie fica acima da amargura dele e inverte a dinâmica tradicional do poder entre pai e filho.

Já a relação entre Dodge e Bradley em Buried Child é caracterizada por uma luta explicita por domínio. O pai e o filho obtêm poder através de meios extremos. Eles anseiam em quebrar um ao outro, e ambos são vistos realizando atos de castração um no outro. Bradley brutalmente corta o cabelo do pai deixando-o exposto e vulnerável e sangrando (p. 82). Simbolicamente o cortar do cabelo pode ser visto como uma invasão de privacidade. Numa outra cena Bradley deixa Dodge desamparado no chão e cobre sua cabeça com um casaco (p. 107). Esse ato pode ser interpretado como um sepultamento imaginário de Dodge, na realidade, as ações de Bradley nos levam a pensar no assassinato do pai. Ele sugere: "We could shoot [Dodge] (...). We could drown him! What about drowning him?” (p. 106). Dodge também anseia em dominar Bradley e seu conselho para Shelly serve para ilustrar esse anseio: "All ya' gotta do is 
take his leg and throw it out the back door. Helpless. Totally helpless." (p. 110). Shelly deixa Bradley totalmente imobilizado e impotente ao retirar sua perna artificial. Os personagens masculinos de Buried Child representam modos de conduta que parecem questionar a definição socialmente construída de masculinidade.

Existem alguns poucos momentos de proximidade entre pai e filho em Buried Child. Ao contrário de Bradley, Tilden não mostra hostilidade em relação ao pai, ele demonstra certo cuidado:

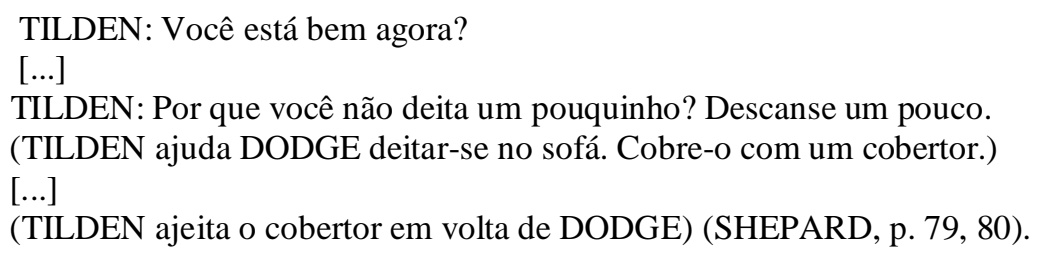

Tilden expressa um desejo pelo amor paternal: "You're not worried about me, are you? [...] You shoulda worried about me [...] Because I was lonely" (p. 71). A fala de Dodge também sugere um traço de preocupação paterna: "Are you in some kind of trouble? [...] You can tell me if you are. I'm still your father" (p. 70). Uma maneira de Tilden expressar seu amor pelo pai é quando ele gentilmente o cobre com a palha de milho fresca (p. 81). Alguns críticos afirmam que essa cena é um enterro simbólico de Dodge, mas ao mesmo tempo pode ser um gesto de amor e carinho e como a palha de milho é fresca pode representar vida e crescimento. Tanto pai quanto o filho têm dificuldade em comunicar verbalmente seu amor um pelo outro.

A maldição de ascendência encontra-se no núcleo de muitas obras de Shepard. Em muitas de suas peças o filho carrega o fardo da geração que o precede. Numa entrevista Shepard argumenta que não há escapatória da família:

\footnotetext{
Estou interessado nas conexões biológicas da família e como aqueles padrões de conduta são passados de geração em geração. De certa maneira é algo sem fim. (em ROUDANÉ, 2002, p. 68).
}

Quando Vince conecta-se com seus antepassados (p.130) em Buried Child nos faz lembrar Weston em Curse of the Starving Class quando o mesmo toma consciência de que seu sangue está infectado com o veneno do seu pai (p. 167). Dodge declara Vince seu herdeiro e quando Dodge morre Vince assume tudo: "This is my house now, ya' know? All mine. Everything" (p. 131). A peça completa o círculo quando Vince se transforma em Dodge: "I've gotta carry on the line" (p. 130) e assume seu lugar.

Shepard juntamente com O’Neill e Miller sugerem que certos traços de caráter são inevitavelmente passados de pais para filhos; os membros da geração mais nova estão fadados a repetir os erros da geração que os precederam.

\subsection{A construção da identidade americana - Sam Shepard reinventando a América}

O mito da fronteira é o nosso mito mais antigo e característico, expresso em um corpo de literatura, folclore, ritual, historiografia, e polêmicas produzido durante um período de três séculos. De acordo com seu mito da historiografia, a conquista do deserto e a subjugação ou deslocamento dos nativos americanos 
que originalmente habitavam a América foram os meios para o nosso alcance de uma identidade nacional. (SLOTKIN, 1973 p. 10)

Cowboys são realmente interessantes para mim - esses caras [...] tomaram este imenso país e não tinham nenhuma regra real. Sam Shepard (CHUBB, 1974 et al., p. 190).

A fascinação admitida por Shepard pelo cowboy e pelo oeste americano permeia praticamente o seu completo corpus literário. Certamente, Shepard aprofunda-se em outras preocupações temáticas. Em Fool for Love (1983) e Lie of the Mind (1985) demonstra seu interesse no relacionamento masculino \& feminino; ele foca no relacionamento pai \& filho em Rock Garden (1964), Curse of the Starving Class (1977), Fool for Love e The Late Henry Moss (2001), para nomear apenas algumas. Ele também examina o papel do artista na sociedade e o processo criativo em peças como Tooth of Crime (1972), Angel City (1976), e Geography of a Horse Dreamer (1974). Shepard experimenta com a música em Suicide in B-Flat (1976) e Operation Sidewinder (1969); ele investiga a influência do passado em muitas de suas peças, incluindo Curse of the Starving Class, Simpático (1994), Buried Child (1978) e States of Shock (1991). Seus interesses são claramente diversos.

Mas Shepard mais consistentemente examina o que ele considera a identidade americana predominante, uma imagem que ele frequentemente representa com as figuras do cowboy, pioneiro e /ou fazendeiro (frequentemente elementos dessas três figuras embaraçam-se nos trabalhos de Shepard). Muitos dos temas acima estão ligados e diretamente relacionados à exploração da identidade americana. Para Shepard, o americano não é meramente definido por meramente viver dentro das fronteiras americanas; de preferência, a identidade americana é formada através de princípios específicos que Shepard percebe como integrais ao caráter nacional.

\subsection{A concepção de Shepard da identidade americana}

Muitas das peças de Shepard estão povoadas com heróis cowboys (que nem sempre são heróicos) os quais ilustram sua preocupação com a influência facciosa e destrutiva de uma identidade nacional ilusória e fictícia. Em maio de 2000, Shepard foi entrevistado e comentou sobre seu interesse em expor os efeitos perniciosos da identidade nacional nos cidadãos como indivíduos. Ele explica:

\footnotetext{
Ninguém nunca realmente sucintamente definiu "o mito do sonho americano". Qual é o sonho americano? É o que Thomas Jefferson propôs? Aquele era o sonho americano? Foi o que George Washington propôs? Foi o que Lincoln propôs? Foi o que Martin Luther King propôs? Eu não sei o que é o sonho americano. Eu sei que ele não funciona. Não só não funciona, o mito do sonho americano criou um caos extraordinário, e que vai ser a nossa morte. (ROUDANÉ, p. 60-70).
}

Enquanto Shepard claramente tem um ponto de vista negativo do conceito de uma visão definidora do que os EUA supostamente representam, ele continuamente cria personagens que sentem a pressão (ou desejo) de atingir um sentimento de identidade nacional. Suas peças sugerem que apesar do mito do American Dream que nunca é sucintamente definido, ele frequentemente se manifesta em certos princípios 
primordiais. As peças de Shepard revelam dois importantes elementos que estão no coração da identidade americana segundo ele: uma forte conexão com a terra e a crença numa auto-suficiência individual e habilidade para fazer tudo ao seu próprio modo (frequentemente representado como o self-made man). Estes dois componentes constituem os animating myths, para usar o termo de C. W. E. Bigsby (1997), que estão no cerne de uma consciência nacional. Estes tipos de mitos retiram sua força $\mathrm{e}$ credibilidade de um mundo predominantemente rural no qual a responsabilidade do indivíduo por seu próprio destino e identidade é um artigo de fé nacional não menos do que individual. Dentro desse contexto, a identidade individual está diretamente conectada a identidade nacional, um argumento que Shepard sustenta em suas peças e escritos.

Em muitos dos trabalhos de Shepard, a conexão americana com a terra tem um papel importante em criar a identidade completa do indivíduo. A terra tem várias funções importantes: é um território para ser domado pelo espírito pioneiro e depois servir aos propósitos agrários do homem. A propriedade da terra mostra permanência (raízes), status e auto-suficiência. A terra também é importante, pois representa a habilidade de produzir algo (com as próprias mãos do homem) da terra. Fazer algo crescer - fazer a terra produzir para você - é mais do que somente um meio de sustento; o fazendeiro está no cerne da identidade americana.

Em 1994, Shepard escreveu um artigo intitulado The Self-Made Man onde ele forneceu uma descrição sobre o termo. Enfatiza a importância da conexão com a terra, juntamente com o papel do auto-determinismo ao formar sua visão do caráter americano:

\footnotetext{
Para ele, começou em um momento de silêncio esmagador. Algo se separou e caiu fora. Instintivamente seu coração entendeu que esse "algo" era a noção de que há muito teria acalentado de si mesmo como um indivíduo distinto, uma entidade americana chamada The Self-Made Man. Ele tinha aprendido através de gerações de antepassados irascíveis com o mesmo conjunto de queixo duro e nariz deformado. Ele tinha fotos deles na lareira. Ferrotipias da época da Guerra Civil do seu tatara avô, um homem chamado Lemuel P. Dodge. Que perdeu uma orelha lutando pelo Norte, um braço no combate pelo Sul, e finalmente foi enforcado por ser "mulherengo" em Ojinaga e arrastado pelas ruas empoeiradas até sua cabeça ser separada de seu torso. Havia outros: os homens com barbas longas e chapéus de palha de abas largas, de pé em cima de vagões de feno gigantes, forcados de madeira na mão, quase uma imagem bíblica contra o céu da pradaria. (Cruising Paradise, p. 3)
}

A descrição de Shepard do self-made man, em seu livro de 1996, o qual é uma coletânea de histórias e lembranças autobiográficas revela muito sobre sua percepção da identidade americana. Em tais descrições ele argumenta que uma narrativa de identidade existe, uma que opera num nível familiar e nacional. Os homens que Shepard descreve possuem uma firme crença na sua habilidade, seu direito absoluto, de construir o seu caminho nos EUA. Shepard está representando uma linhagem que aparentemente incorpora o que é ser nascido nesse país. O relato sobre essas gerações anteriores serve para entrelaçar a família e a nação de tal maneira que elas deixam de ser entidades separadas. Os avós individuais passam a ser identificados por seus papéis na história americana como soldados e pioneiros, homens que mantinham uma convicção absoluta 
na adequação das suas ações. Para o self-made man de Shepard essa identidade torna-se uma experiência religiosa, quase bíblica.

Mas essas mesmas linhas revelam o poderoso sentido de perda que Shepard argumenta que os americanos experimentam na sociedade moderna. O conceito estável do selfmade man caiu de moda. O americano de Shepard continuamente buscará recuperar essa antiga e tão acalentada noção dele mesmo como um indivíduo distinto do qual ele acredita ser exclusivamente uma entidade americana. Na maioria das vezes eles não serão bem sucedidos. As tentativas dos personagens de Shepard de chegar a um acordo com essa realização - que a visão familiar deles da identidade americana está em última análise inacessível - é um tema que Shepard examina ao longo de sua carreira.

No trabalho de Shepard, o caráter americano é frequentemente representado pela figura do cowboy, uma imagem que Shepard tanto admira quanto critica severamente. Apesar de retornar continuamente a essa imagem em suas peças, ele a trata ambiguamente. A imagem do cowboy é apresentada como a idealização da identidade americana, sendo que os personagens de Shepard constantemente buscam reconectar-se com o espírito pioneiro incorporado dentro dessa imagem. Mas Shepard reconhece que essa identidade americana existe mais na ilusão e memória do que na realidade. Seu trabalho continuamente ilustra a artificialidade da narrativa da nação que agora funciona como uma força destrutiva, pois os americanos tentam alcançar uma identidade que foi construída com mitos e meias verdades. Shepard retrata o cowboy como uma representação incompleta do caráter nacional, ele caracteriza uma identidade americana extremamente masculina que é inclinada à violência, e ao mesmo tempo ele expõe sua natureza artificial e construída.

Vários dos personagens de Shepard incorporam essa identidade americana completa. Enquanto eles tentam alcançar um modelo idealizado do cowboy/pioneiro que como Shepard afirma é perpetuado pela cultura, história e literatura americana; e que frequente e involuntariamente revelam a completa e mais negativa imagem do caráter americano. Uma das mais explícitas e reveladoras representações do caráter americano aparece em Montana. É um conto publicado no livro Hawk Moon (1973), o qual retrata o derradeiro cowboy, vestindo-se num quarto de hotel em Nova Yorque:

Puxou seu traje de cowboy favorito: botas brancas de pele de canguru com desenhos de flores vermelhas e um salto alto de montaria. Grandes chaparreiras de couro com franjas e tachas de prata Navajo. Uma camisa preta de cetim Gene Autry com pistolas brancas bordadas na gola e nos punhos. Sua bandana favorita laranja brilhante Roy Rogers. Sua máscara do Lone Ranger. E um chapéu Stetson preto com uma corda no queixo. Finalmente ele tirou as esporas de ouro com correntes de prata e tiras de couro. Ele colocou todas elas no chão em uma ordem certa para que se parecessem com a forma de um homem. O Super Cowboy Man. (p. 21-22)

O traje do Super Cowboy Man busca por autenticidade, porém é flagrantemente inventado, forjado. Cada artigo desse traje é selecionado de ícones da cultura popular e de filmes de faroeste. Shepard cria uma imagem ao dispor as roupas no chão para que elas se pareçam com a forma de um homem enfatizando ainda mais a natureza construída dessa identidade particular; a figura desse cowboy no chão dá a impressão de que um indivíduo somente precisa entrar nessa configuração para tornar-se essa imagem, sendo assim a linguagem de Shepard mostra a artificialidade da identidade do cowboy. 
A incongruência do Super Cowboy Man é enfatizada pelos detalhes específicos do seu traje. Camisas de seda e botas de pele de canguru estão diretamente em conflito com a pessoa do cowboy. O modo de transporte que ele utiliza parece estranhamente inadequado também; ao invés de montar no seu cavalo e galopar ao pôr do sol, "he walked out to hail a cab... He swung in with his spurs jangling and said: 'Montana please'." (SHEPARD, 1973, p. 23). Cada aspecto do Super Cowboy Man desmente a autenticidade de seu status como emblema nacional.

O Super Cowboy Man também ostenta uma tendência à violência. Montana inicia com o cowboy colocando notas de cem dólares sobre o cadáver de uma mulher que ele acabou de matar. Sua atitude indiferente em relação às suas próprias ações violentas exemplifica a inseparável associação de violência com sua (e por extensão, dos EUA) identidade. Depois de cobrir o cadáver ele vai até o bar para tomar uma bebida, ele retorna para o quarto e leva o cadáver para banheira, joga gasolina, e ascende uma pira, "leaving nothing but bones and teeth on the white porcelain" (p. 23) antes de partir para Montana. Suas horrendas ações não provocam nenhum tipo de remorso; ele permanece cold and empty ao cometer atrocidades tão violentas. Essa dessensibilização (e inclinação) para violência será uma caracteristica recorrente nos personagens de Shepard.

Essa propensão para violência, Shepard sugere, é uma parte integral da construção masculina da identidade americana. Os homens nas peças de Shepard são agressivos e hostis, e frequentemente empunham armas. Em A Lie of Mind, Jake praticamente espanca Beth até a morte, em True West, Lee tenta estrangular seu irmão Austin com o cordão de um telefone, em Geography of a Horse Dreamer, Jasper e Jason abrem caminho para entrar num hotel com uma rajada de balas, matando três. Armas estão presentes em Cowboy Mouth, Suicide in B-flat, Seduced, Geography of a Horse Dreamer, Curse of the Starving Class, A Lie of the Mind, States of Shock, Tooth of Crime, Operation Sidewinder, Mad Dog Blues, The Unseen Hand, Fool for Love, La Turista e Cowboys \#2, entre outros trabalhos da carreira de Shepard. A propensão de Shepard em criar personagens (masculinos) que exibem conduta violenta e ao mesmo tempo adotam os ideais da identidade americana demonstram sua associação do caráter nacional com violência e agressão.

O Super Cowboy Man de Shepard expõe um caráter americano com inúmeras falhas fundamentais: a imagem predominante do pioneiro americano é violenta e não autêntica. Shepard comprova que a violência sempre foi não enfatizada ou glorificada pela cultura e história americanas, o que resultou na aceitação daquelas tendências violentas. A artificialidade do Super Cowboy Man revela sua desconexão de qualquer herança americana verdadeira, pois o cowboy de Shepard consiste em um pastiche de imagens fílmicas que tem pouca semelhança com a realidade da vida no oeste americano do passado e do presente.

De acordo com Shepard, a cultura americana é responsável por apresentar e promover um caráter nacional que é em última análise inacessível para os seus cidadãos. Numa entrevista em 2000, ele escreve uma observação perspicaz sobre a diferença que ele percebe existir entre a identidade americana na narrativa cultural e a realidade histórica:

Quero dizer, se você quiser- e eu não sou um historiador- mas é muito interessante rastrear esse imperialismo europeu, esta noção de que não apenas 
nos foi dada esta terra por Deus, de alguma forma, mas que também estamos autorizados a fazer tudo o que queria com ela, independentemente das consequências, e colher todas as fortunas da terra, muito em detrimento de todos "abaixo" desta classe, desenfreadamente puritana do colonialismo europeu ... com certeza, Lewis e Clark e os outros caras eram um tanto heróicos, eram vigorosos, eles tinham toda essa vitalidade e eles tinham toda essa aventura de entrar em território estranho e todo esse material, mas por trás dessa coisa toda estão os europeus famintos por terra querendo dominar. Que está por trás de todo o negócio [...] Eu acho que nós sempre somos vítima da publicidade de ir buscar. De campanhas publicitárias. O movimento para o oeste foi promovido pela publicidade. Você sabe, "Venha para o oeste!" "Terra Livre!" "Destino Manifesto". Então nós sempre fomos seduzidos pela publicidade [...] Nós caímos nessa coisa, você sabe. Assim, o sonho americano é sempre essa fantasia que é promovida através da publicidade. Nós sempre preferimos a fantasia sobre a realidade. (ROUDANÉ, Interview, p. 70)

Os comentários de Shepard revelam sua crença na culpabilidade da América em promover e perpetuar um falso mito, um que ainda não foi alcançado e é apresentado como um ideal americano. Os cidadãos americanos são "seduzidos por anúncios" que emergem em parte da literatura nacional, sua visão da história americana, e talvez o mais importante para Shepard da cultura popular americana. Apesar de Shepard admitir que existam tantas definições do mito do sonho americano, sua visão da identidade americana continuamente se refere à reivindicação da terra pelos americanos e a fé inabalável deles na própria habilidade de prosperar nessa terra. As peças de Shepard e seus escritos continuamente desafiam a validade desses princípios americanos.

Para Shepard, esse paradoxo da identidade nacional cria discórdia e descontentamento; as falhas de suas personagens em grande parte derivam de sua imagem falaciosa e incompleta do caráter americano. Enquanto os personagens de Shepard progressivamente tornam-se mais conscientes da sua paradóxica e potencialmente situação auto-destrutiva em busca de uma identidade, somente alguns dos seus mais recentes personagens mostarm evidência de chegar a um estágio onde eles possam na verdade recuperá-la. A luta desses personagens para atingir esse estado de compreensão torna-se um ponto focal no drama de Shepard; suas peças ilustram essas tentativas, e fracassos para atingir a visão do destemido pioneiro americano,uma visão que é predominantemente construída de ilusão e mito ao invés de baseada na realidade. Essa imagem enganosa glorifica o espírito pioneiro e potencial irrestrito para o sucesso enquanto não realça suas tendências violentas e inacessibilidade total. Shepard afirma que essa imagem da identidade nacional impõem-se sobre a individual fazendo com que qualquer descoberta verdadeira de identidade seja quase impossível.

\subsection{A identidade americana na literatura}

O conceito de identidade americana não foi criado num vácuo por Shepard. Ele responde à imagem do americano enraizada e de longa data que está documentada na literatura nacional assim como na cultura e história. Os comentários de Shepard sobre as raízes européias americanas parecem recordar a formação da literatura nacional que emergiu durante os anos de formação da guerra revolucionária americana (1775-1783). Os escritores que produziram materiais durante esse período eram europeus transplantados que tentaram recriar sua identidade para abraçar os ideais da nova nação. Eles ajudaram a arraigar uma narrativa de uma nação que, como sugere Sam Shepard, 
ainda ressoa na sociedade contemporânea. Muitos escritores americanos conscientemente tentaram criar não somente um senso de patriotismo, mas também estabelecer uma identidade nacional para seus cidadãos abraçarem como um ideal americano. Escritores como Benjamin Franklin, Thomas Jefferson, e Hector St. Jean de Crèvecouer produziram literatura que também serviu de documento histórico do novo status da América como um país recém criado, esse autores procuraram construir uma literatura de formação da nação que documentaria um americano modelo. Muito dessa literatura parece enquadrar-se na categoria de anúncio promocional, pois esses autores tentavam vender uma visão específica da identidade americana.

Hector de Crèvecouer criou talvez a conexão mais evidente entre o "americano" e sua terra. Sua publicação de 1872, Letters from an American Farmer and Sketches of Eighteenth-Century America (cujo título imediatamente enfatiza a importância fundamental da terra para um americano), contém uma carta inteira intitulada "What is an American?" Ele continuamente enumera os valores da propriedade de terra, revelando esse aspecto como uma fonte de identidade para os americanos. Na sentença de abertura de uma carta para um amigo na Europa, ele conecta-se a terra ao saudar o amigo: "Behold, sir, a humble American planter, a simple cultivator of the earth" (p. 37) Ele revela então de forma completa a importância da terra para ele e para identidade americana:

\begin{abstract}
No instante em que eu entrar na minha terra, a brilhante ideia de propriedade, do direito de exclusivo, de independência, exaltarei o meu espírito. Solo precioso, digo para mim mesmo, pelo o que o costume singular da lei é que os resíduos tu fez para constituir as riquezas do proprietário? O que devemos ser nós os agricultores americanos sem a posse distinta de tal solo? Ele nos alimenta, ele nos veste; dele tiramos até uma grande exuberância, a nossa melhor carne, a nossa mais rica bebida; o mel da nossa abelhas vem dessa local privilegiado. Não admira, que assim, devemos valorizar a sua posse; não admira que tantos europeus que nunca foram capazes de dizer que a parcela da terra era deles cruzaram o Atlântico para perceber aquela felicidade. Este solo anteriormente rudee foi convertido por meu pai em uma fazenda agradável, e, em contrapartida, estabeleceu todos os nossos direitos; em que se funda a nossa posição, nossa liberdade, nosso poder como cidadãos, a nossa importância como habitantes de uma tal distrito. Estas imagens, devo confessar, eu sempre as mantenho com prazer e as estendo, tanto além quanto a minha imaginação pode chegar, porque isso é o que pode ser chamado de verdadeiro e a única filosofia de um fazendeiro americano. (p. 54)
\end{abstract}

As linhas da carta de Crèvecoueur revelam mais que a filosofia de um fazendeiro americano; elas revelam parte da filosofia dos EUA. A terra provê mais para um americano que meramente o sustento produzido na fazenda. Torna-se explicitamente associada a status, liberdade, auto-suficiência num nível geral, e num nível mais específico a terra torna-se a raiz dos direitos do cidadão americano. Também é uma maneira de distinguir os EUA dos outros países. A propriedade da terra passa a ser um elemento básico da identidade americana que foi escrita na constituição para determinar fundamentais liberdades cívicas tais quais o direito de voto.

Crèvecouer observa que apesar dos americanos diferirem dependendo da região do país na qual eles moram, eles são definidos pela própria terra que ocupam: "Men are like plants; the goodness and flavour of the fruit proceeds from the peculiar soil and exposition in which they grow" (p. 71). No entanto ele não descarta outros fatores 
relevantes na criação do caráter individual, tais quais "the government we obey, the system of religion we profess, and the nature of our employment" (p. 71). E significativo que Crèvecoeur identifica a terra juntamente com "the air we breathe" e o "climate we inhabit" (p. 71), como influência primária na construção do nosso caráter, tanto como indivíduos como cidadãos nacionais. Sua tendência a empregar analogias da natureza enfatiza a importância substancial do mundo natural na formação da identidade americana.

Shepard menciona sua conexão ao lugar onde cresceu. Durante seu período de exílio auto-imposto de três anos na Inglaterra, Shepard adquiriu uma nova perspectiva sobre sua terra natal. Numa entrevista em 1974 (ainda em Londres) ele diz: "I mean it wasn't until I came to England that I found out what means to be an American. Nothing really makes sense when you're there, but the more distant you are from it, the more the implications of what you grew up with start to emerge" (CHUBB et al, p.198). Ele afirma que a conexão do indivíduo a um lugar até afeta seus padrões de fala: "I have a feeling that the cultural environment one is raised in predetermines a rhythmical relationship to the use of words. In this sense, I can't be anything other than an American writer." (SHEPARD, Language, p. 52).

A conexão de Shepard com a terra emerge de suas respostas para repetidas questões sobre seus laços com o oeste americano:

Eu sinto que o Oeste é muito mais antigo do que o Leste. [...] Há áreas como Wyoming, Texas, Montana e lugares assim, onde você realmente sente essa coisa antiga sobre a terra. Antiga. Que é primordial. [...] Tem a ver com a relação entre a terra e o povo - entre o ser humano e a terra. (LIPPMAN, 1984, p. 10)

A articulação de Shepard sobre o significado da terra como uma força modeladora da identidade reforça os comentários de Crèvecoeur de mais de trezentos anos antes. Ambos enfatizam a conexão do americano ao solo embaixo dos seus pés.

A ênfase de Crèvecoeur sobre a terra e a natureza aparece na literatura daquele período. Thomas Jefferson, em suas Notes on the State of Virginia (originariamente publicada em 1781), provê um relato exaustivo da vida animal e vegetal do estado, assim como uma detalhada descrição do terreno, incluindo montanhas, rios e cachoeiras. Jefferson também exorta a América a manter sua identidade agrícola em um capítulo intitulado "Manufacturers", Jefferson estimula a nação a focar sua atenção em produzir da terra, deixando a manufatura e produção industrial para Europa:

\footnotetext{
Enquanto temos terra para trabalhar, então, não vamos querer ver os nossos cidadãos ocupados em uma mesa de trabalho ou girando uma roca. É melhor levar provisões e materiais para os trabalhadores lá, do que trazê-los para as provisões e materiais, e com eles seus costumes e princípios. A perda durante o transporte de mercadorias através do Atlântico será feita em felicidade e permanência do governo. [...] São as maneiras e o espírito de um povo que preservam uma república em vigor. (p. 216)
}

Assim como Crèvecoeur, Jefferson diretamente conecta a ideologia da nação com a terra geográfica que constitui as fronteiras da América. Essa paisagem que ambos exaltam desempenha um importante papel não somente em termos de valores agrícolas de sustento e produção; também representa um lugar selvagem não domado que pode ser explorado e dominado pelo homem. Esse sentido pioneiro de expansão e 
dominação-fazendo com que a terra sirva aos propósitos do homem-forma um elemento integral da ideologia americana. Ao aspecto do potencial da fronteira é que Shepard continuará retornando em suas peças. Os personagens de Shepard frequentemente anseiam mover-se para fora dos territórios como uma visão idealizada da existência americana. É esse impulso que irá compelir Austin a almejar uma vida no deserto, e instilar o desejo em Wesley de escapar para o Alasca, a última fronteira restante, porque "it's full of possibilities. It's undiscovered" (Curse of the Starving Class, p. 163).

Crèvecoeur passa a maior parte do seu trabalho elogiando o estilo de vida agrário, ele teve um importante papel em codificar a imagem do pioneiro como um ícone nacional. Num esforço de escapar dos horrores da guerra revolucionária americana, ele e sua família abandonaram a fazenda, um ato do qual ele profundamente se arrependeu, não somente pela perda da fazenda, mas também por ter 'domado' a terra ele mesmo. Refletindo sobre a terra abandonada ele lamenta:

Talvez eu nunca possa rever esses campos que eu limpo, as árvores que plantei, estes prados que, na minha juventude, eram um deserto medonho, agora convertido pelo meu trabalho em pastagens ricas e gramados agradáveis. Se na Europa é louvável estar anexado a herança paterna, quanto mais natural, quanto mais poderoso devem ser os laços entre nós, que, se me é permitido a expressão, são os fundadores, os criadores, de nossas próprias fazendas! (Letters, 1872, p. 216)

A linguagem de Crèvecoeur retrata-o como um pioneiro que veio, viu a terra e conquistou-a, transformando a paisagem em algo útil para seus propósitos. Essa imagem idealizada do pioneiro, como Leo Lemay (que organizou a autobiografia de Benjamin Franklin) assinalou, torna-se uma figura recorrente na literatura americana. Leo Lemay afirma que "he first [...] interprets American society and culture according to a model that aggrandizes the role of the frontier and the frontiersman." (LEMAY, 1997, p. 197). Os pioneiros passam a representar os americanos que estavam ocupados construindo uma nação. Tanto na época de Crèvecoeur assim como nas gerações de literatura americana que o seguiram, "the frontiersman is often a hero and always a unique American phenomenon." (p. 193).

Apesar do principal tema das Letters from an American Farmer focar na importância da terra, para sobrevivência física assim como identificação ideológica tanto a nível individual como nacional, seus escritos também revelam um outro atributo primário que Shepard vê como integral para a imagem da identidade americana: o self-made man. As Letters from an American Farmer exemplificam a história de sucesso americana: ele construiu sua própria fazenda, estabeleceu uma família e adquiriu riqueza financeira e propriedade. Como um bom americano o acúmulo de riqueza e propriedade nunca se distanciou da sua mente. Numa das passagens em Letters ele menciona que vai caçar abelhas e não ursos. A motivação dele em fazê-lo é puramente financeira, como ele mesmo admite: "I cannot boast that this chase is so noble or so famous among men, but I find it less fatiguing, and full as profitable; and the last consideration is the only one that moves me" (Letters, p. 59).

O objetivo primário do new colonist (o americano) deve ser o acúmulo de propriedade:

Vamos ver agora o colono novo como possuidor de propriedades. Isso tem um peso grande e um poder de influenciar. Desde a mais tenra estamos 
acostumados a uma maior troca de coisas, uma maior transferência de propriedade do que as pessoas da mesma classe na Europa. [...] Este homem, assim criado, a partir de uma variedade de razões está determinado a melhorar a sua sorte através da remoção para um novo bairro e resolve comprar tanta terra quanto puder pagar para cada um de seus filhos - um pensamento piedoso que faz com que tantas pessoas, mesmo os ricos venderem seus bens patrimoniais para ampliar sua esfera de ação e deixar uma herança suficiente para sua progênie. (1872, p. 254)

A aquisição de terra torna-se uma preocupação central para o americano, pois o provê com uma segura herança para sua família e também com um visível testamento da sua riqueza, que equaciona diretamente com reputação e prestígio social. Riqueza e propriedade tornam-se fatores determinantes na definição do 'self-made man e selfsufficient man' que constituem em parte a identidade americana. Eles criaram a aparição do sucesso que confirma a realização da busca do cidadão de incorporar o caráter americano.

Crèvecoeur detalha seu próprio sucesso para acumular riqueza e propriedade. Ele ensina a suas crianças os valores da vida americana que ele adotou e seus relatos também ajudarão a edificar outros. Ele provê exemplos específicos da história de sucesso americana, incluindo o relato sobre: Andrew the Hebridean, no qual um homem vem para América sem nada e através de "sobriety, honesty, and industry" (p. 91) adquire terra, riqueza e status. Tal ilustração fala ao coração da identidade americana, onde um homem pode erguer-se da obscuridade para alcançar o sonho. Tal oportunidade exemplifica a vida na América, afirma Crèvecoeur:

Vindo do nada para começar a existir, a partir de um servo ao posto de um mestre; de ser o escravo de um príncipe despótico, para se tornar um homem livre, investido de terras a que todas as bênçãos municipais é anexada! Que mudança de fato! É em consequência dessa mudança que ele se torna um americano. (p. 83)

Suas Letters tornam-se um testemunho de um ideal americano. Seu esforço em prover um modelo para outros exemplifica a afirmação de Sam Shepard que a América usa "advertising campaigns" para promover uma visão específica da identidade nacional. Shepard afirma que: "the American Dream is always this fantasy that's promoted through advertising" (p. 70), e o trabalho de Crèvecoeur encaixa-se nessa descrição. Benjamin Franklin também tenta criar um texto que sirva como um diagrama para o sucesso americano. Ele claramente anuncia suas intenções na abertura de sua carta para seu filho:

Tendo emergido da pobreza e da obscuridade em que nasceu e cresceu, a um estado de afluência e algum grau de reputação no mundo, e ter ido tão longe thro vida , com uma quota considerável de felicidade, a realização de meios dos quais fiz uso, que, com a bênção de Deus, assim bem sucedido, minha posteridade pode gostar de saber, como eles podem encontrar alguns deles adequados às suas próprias situações e, portanto, digno de ser imitado. (FRANKLIN, p. 1).

Podemos dizer que os dois autores não focam nos mesmos aspectos da identidade americana, Franklin seria o protótipo prático real do americano enquanto que Crèvecoeur seria o emocional. Ambos promoveram a habilidade do americano de alcançar o sucesso pessoal e ambos tentaram responder o que é ser um americano. 
Os personagens de Sam Shepard não conseguem responder com sucesso a essa questão. Eles constantemente lutam pelos mesmos objetivos de riqueza e propriedade; entretanto, a eles é negado uniformemente o acesso a essas aspirações. Seus personagens, ao contrário das figuras literárias tais como James o plantador americano (representante da identidade americana idealizada por Crèvecoeur), não são modelos positivos a serem imitados pelas futuras gerações; ao contrário, são fracassados incompetentes que são incapazes de atingir qualquer senso de prosperidade e consequentemente incapazes de incorporar a percepção da identidade americana. Shepard demonstra uma clara conscientização do impacto do 'farmer/pioneer' como uma imagem dominante do caráter americano. Suas peças estão povoadas por personagens os quais almejam ser fazendeiros (Eddie em Fool for Love, Wesley em Curse of the Starving Class) ou aqueles que fracassaram na sua tentativa (Weston em Curse of the Starving Class) ou mesmo aqueles que buscam recapturar o espírito pioneiro que construiu a nação (Henry Hackamore em Seduced).

\title{
2.10 O que é ser americano? O que está errado com esse retrato?
}

Vários trabalhos foram escritos onde foram expostas imagens de uma única e unificada identidade americana como insustentável. Gerald Kreyche observa que enquanto a imagem do "pioneer/cowboy" "helped produce [...] a new virtually unique and authentic man-a homo Americanus" (KREYCHE, 2009, p. 3), ela era mais conflitante do que unificada:

\begin{abstract}
A ascensão do Ocidente, portanto, foi caracterizada por uma série de manobras contraditórias em direção a subjugação e liberdade, a utilização e exploração, destruição, conservação e libertação. Entendida como uma luta dialética para tentar produzir uma nova síntese, o processo oferece polaridades infinitas. Entre essas forças opostas estavam católicos romanos e protestantes, o homem branco e o índio o, americanos e mexicanos gentil, e mórmon, agricultor e pecuarista, irlandeses e chineses, tribos indianas, e acima de tudo, o homem e a natureza. (p. 5)
\end{abstract}

Kreyche (2009) observou precisamente que existe mais contradição que consenso dentro da imagem do caráter americano retratado pelo Westener.

Além das numerosas inconsistências inerentes a visão do americano, tal visão da identidade nacional também desmente a miríade de experiências de uma nação diversificada de pessoas cujas histórias são frequentemente marginalizadas ou ignoradas pela noção de um único conceito sobre 'o americano'. Jane Tompkins, em seu estudo sobre filmes de faroeste, observa que o gênero foca quase que exclusivamente em homens brancos: "Indians are repressed in Westerns - there but not there - in the same way women are." (TOMPKINS, 1993, p. 9); assim qualquer personagem que não é branco é retratado como o 'Outro', como se ele ou ela não fosse retratado de nenhuma maneira.

Richard Slotkin discute a maneira repressiva na qual a América esculpiu sua identidade. Ele afirma: "Violence is central to both the historical development of the Frontier and its mythic representation. The Anglo-American colonies grew by displacing Amerindian societies and enslaving Africans to advance the fortunes of White colonists." (SLOTKIN, 1992, p. 11). 
Em seu Virgin Land: The American West as Symbol and Myth, Henry Nash Smith efetivamente desacredita a imagem da identidade americana que Shepard frequentemente evoca. $\mathrm{O}$ autor traça as identidades divergentes que se desenvolveram tanto na literatura quanto na história. Baseando-se nos trabalhos de James Fennimore Cooper, Smith afirma que as primeiras representações literárias do pioneer/frontiersman o retrata como um anti-herói que recuou para o lado selvagem da natureza numa tentativa de escapar da civilização: "The aged Leatherstocking has likewise [like the actual Daniel Boone] 'been driven by the increasing and unparalled advance of population to seek final refuge against society in the broad and tenantless plains of the west" (SMITH, 1981, p. 50-60). Esses pioneiros iniciais não representam um ideal americano tanto como párias sociais.

Conforme a imagem do pioneiro se desenvolve, Smith afirma que a expansão para o oeste criou três divisões principais na sociedade: "a remote fringe of backwoods settlements, a central region comfortable farms, and to the East, a region of growing wealth, cities, and social stratification." (p. 126-127). De acordo com Smith, essa divisão do meio é a mais significativa em termos de ser elevada ao nível do mito nacional. Foi dentro dessa região que o ideal agrário foi fundado, um que enfatizava o papel da terra (e a habilidade individual de adquirir e trabalhar na terra com sucesso). Homens como Thomas Jefferson ajudaram a promover esse ideal; no estado de Virgínia, ele propôs que cada adulto recebesse 50 acres de terra pública porque "he saw the cultivator of the earth, the husbandman who tilled his own acres, as the rock upon which the American republic must stand." (p. 128). A conexão americana com a terra está firmemente impressa na narrativa da nação.

É difícil simplesmente categorizar a imagem agrária americana. Smith observa: "By 1830 there were thus two agrarianisms in the place of one, and their inherent opposition to one another was to become clearer with each passing decade until it reached a climax during 1850's in the contest for control of the territories beyond Mississsippi." (1981, p. 133). No norte, a agricultura desenvolveu-se com o homem livre trabalhando sua própria terra, ao passo que no sul o sistema de plantação desenvolveu-se baseado no trabalho escravo de outros. A contradição inerente nessas duas imagens contrastantes do agrarianismo obviamente seria um dos fatores que conduziria ao conflito que culminou na Guerra Civil.

A Lei da Propriedade Rural (Homestead Act) foi uma lei dos Estados Unidos da América criada pelo presidente Abraham Lincoln no dia 20 de maio de 1862. Grandes contingentes de imigrantes europeus participaram da ocupação do vasto oeste americano e, sem eles, essa conquista não se realizaria. Para atrair imigrantes, o governo norteamericano decretou, em 1862, o Homestead Act, que definia a posse de uma propriedade com 160 acres a quem a cultivasse por cinco anos essa lei fez aumentar muito o fluxo de imigrantes europeus para os Estados Unidos. A conquista do oeste que teve início com a compra da Louisiana e terminou com a compra do sul do Arizona, em 1853 - coincidiu com o período de industrialização dos EUA.

Essa lei, segundo Smith, contribuiu para a imagem do ideal americano:

O apelo mais forte do sistema de propriedade rural para o oeste, um recurso que tinha tocado a níveis mais profundos da experiência norte-americana no século XIX, estava na crença de que ele iria aprovar por lei o império livre e simples, a utopia agrária do trabalhador e virtuoso 'yeoman' que tinha 
assombrado as imaginações de escritores sobre o oeste desde os tempos de Crèvecoeur. (SMITH, 1981, p. 170)

\subsection{Sam Shepard e o cowboy mítico}

Apesar da noção do ideal americano ser complexa e problemática, ela continua a permear a consciência do povo. Para Sam Shepard as imagens fomentadas daquela identidade sempre foram versões simplificadas que ignoraram as realidades.

Henry Nash Smith acredita que as imagens idealizadas do fazendeiro americano e do pioneiro, apesar de imprecisas, podem dominar a percepção da cidadania sobre a identidade nacional. Tanto Smith quanto Shepard parecem perceber que enquanto essas imagens da identidade americana podem ser falsas e incompletamente retratadas, elas também são forças poderosas na sociedade. Certamente, Shepard está consciente das imprecisões da visão dos seus personagens da identidade americana. Ainda assim ele continua retornando aos mesmos elementos - a conexão americana com a terra e sua habilidade para ser bem sucedido trabalhando a terra. Talvez seu ponto seja que a sociedade como um todo seleciona seu conceito de identidade nacional de fontes imprecisas e mais amplas como os anúncios/ propagandas aos quais ele se refere.

Shepard é um dramaturgo pós-modernista que retira inspiração de diferentes fontes, entre elas literatura, história e cultura popular de maneira a criar uma colagem de imagens que constituem seu Super Cowboy Man. A imagem da identidade americana que Shepard construiu pode não ser a mesma de Henry Nash Smith ou Jane Tompkins ou Richard Slotkin. É provável que muitas pessoas na platéia nunca tenham lido nada escrito por esses autores, porém tanto eles quanto Shepard foram expostos a imagens incontáveis que anunciam a identidade americana-imagens que apareceram em filmes ${ }^{5}$ Paralelamente, ele se tornou ator realizando pequenas participações em filmes e seriados levados para a televisão, e escreveu roteiros para seriados conhecidos como Gunsmoke, The Rifleman e The Westerner. Estreou como diretor de televisão em Lança Partida, dirigindo depois vários capítulos de outras séries televisivas, mas foi só em 1960 que ele escreveu o roteiro para um faroeste que seria filmado como A face oculta, estrelado por Marlon Brando. Consagrou-se como um dos mais vigorosos e hábeis cineastas estadunidenses pela utilização estética da violência e da brutalidade na maioria das suas obras. Ele desenvolveu um cinema cheio de realismo, no qual a característica principal não era a violência que os filmes continham e sim a forma como ele a manipulava em função de seus personagens. Mas a grande contribuição de Peckinpah foi a concepção de um cinema moral (não moralista) que buscou pensar a tomada de decisão, as escolhas éticas e todas as perturbações daí decorrentes. Seu diálogo está em linha direta com o western anterior, marcado por certa ingenuidade moral, notadamente naquelas obras de John Ford. Dois exemplos excelentes são: Rastros de Ódio (1956 - no qual o matador de índios perde sua função no seio e harmonia familiar) e $\mathrm{O}$ Homem que matou o fascínora (1962 - que contrasta a nova América versus a antiga América).

Em Peckinpah o mundo está deserdado de seus mitos redentores, os homens se deparam com a crise histórico-social em processo e ascensão da sociabilidade capitalista. Um forte exemplo disso está em sua obra máxima, The wild bunch (Meu ódio será sua

\footnotetext{
${ }^{5}$ Shepard refere-se à cena final de Geography of a Horse Dreamer como a "Sam Peckinpah sequence," Descendente de índios paiutes e formado em Arte Dramática, Peckinpah começou sua carreira em 1954, como escritor de diálogos no filme Rebelião no presídio, de Don Siegel.
} 
herança). Ali, o contexto é aquele da formação das grandes fortunas, numa acumulação primitiva de capital perpetrada pelos famosos "Barões bandidos". Nessa acumulação, os indivíduos que não souberam acompanhá-la caem para as margens, lutando contra a nova tecnologia de guerra e os novos meios de gestão com um código de conduta précapitalista, por exemplo [BOTTOMS, 1998, p. 104]), e dime store novels (Henry Nash Smith afirma que a natureza previsível dos dime store novels representa "an objectified mass dream" que expressa "the dream life of a vast inarticulate public." (SMITH, 1981, p. 91-92), shows na TV (nos seus trabalhos em prosa, Shepard frequentemente refere-se aos personagens de TV tais como Lone Ranger e Gabby Hayes) e canções (a conexão e interesse de Shepard por 'rock and roll' é conhecida do público; ele até escreveu Brownsville Girl com Bob Dylan). Na realidade, uma das imagens mais celebradas e discutidas de Shepard originou-se de uma História em Quadrinhos. Na biografia de Shepard escrita por Ellen Oumano em 1986 ela revela a fonte da imagem da águia/gato, recontada por Scott Christopher Wren, que participou da oficina conduzida pelo dramaturgo Shepard:

\footnotetext{
Wren relata uma história em que o Ruby Cohn, o principal estudioso de Beckett, estava discursando sobre a imagem final de Curse of the Starving Class, no qual uma águia e um gato batalham pelos testículos de uma galinha [mas na verdade é, "cordeiros novos"] que acabaram de ser cortadas. A águia agarra o gato e os dois estão no ar, rasgando um ao outro, coragem, e então eles caem no chão: "Ruby falou sobre este episódio e como essa imagem está no centro da peça e do seu trabalho inteiro, e Shepard está sentado lá na cadeira, sorrindo. O sorriso está ficando maior e maior. Finalmente, ela the pergunta, 'Como foi que esta imagem veio na sua mente?' Shepard riu e disse: 'Lembre-se daqueles livros velhos de aventura em quadrinhos? "Ele tinha chegado a esta ideia a partir de uma dessas coisas. Todos na sala racharam de rir. "(OUMANO, 1986, p. 135).
}

Numa entrevista posterior, Shepard confirmou essa história, e adicionou que essa imagem lhe ocorreu de suas próprias experiências vividas numa fazenda: "When you castrated ram lambs, there would always be a hawk or something around" (ROSEN, 1993, p. 3). Isso ilustra que as influências de Shepard são baseadas na cultura popular. Como C. W. E. Bigsby conclui:

Shepard foi o primeiro dramaturgo a construir seu drama a partir dos materiais das artes populares, para infiltrar os sons e imagens da cultura popular no seu trabalho que transmitiu seu significado menos para aqueles que se aproximaram com uma mente analítica do que para aqueles que escolheram habitar suas imagens e responder a seus ritmos em um nível emocional ou visceral. (BIGSBY, 1985, p. 171)

Esses são os sons e as imagens das quais Shepard extrai seu material, e ele afirma que são essas imagens da cultura pop que perpetuam a construção das falhas do caráter nacional. Na realidade histórica, as figuras do fazendeiro, vaqueiro, pioneiro, colono e soldado da cavalaria são entidades distintas e discretas. Porém nas obras de Shepard essas figuras são combinadas no Super Cowboy Man, um personagem complexo e composto que provavelmente continuará a reaparecer nas peças escritas por Shepard ao longo de sua carreira. Ele praticamente tornou-se uma fixação nas peças de Shepard, as quais são povoadas por personagens que procuram viver uma vida idealizada na fronteira americana um século após o fechamento oficial da fronteira. A noção de colono usada por Shepard enfatiza a correlação entre dois elementos primários das idenditade americana. Enquanto o pioneiro tem claramente uma conexão direta com a 
terra, ele também incorpora o conceito de auto-suficiente, do homem que se fez pelo esforço próprio ao conquistar a terra. O território indomável que se espalhou para o oeste ofereceu aos americanos a oportunidade de abraçar uma florescente ideologia nacional de auto-suficiência que retira sua força da paisagem. Como uma nação, "our fanatical faith in self-reliance was confirmed by the experience of the frontier", a qual "contributed to the shaping of a uniquely American attitude" (PORTER, 1969, p. 17). Mais que a demarcação política entre dois países ou o limite entre regiões habitadas ou colonizadas, a linha divisória entre duas culturas ou civilizações, a fronteira é um lugar de encontro e colisão de culturas, de mundos distintos e, em geral, incompatíveis; a fronteira é um espaço cultural, é o lugar de encontro entre eu e o outro. Na realidade somos a fronteira. É, no fundo, um conflito de identidades, que se apresentam irreconciliáveis e sem dúvida, o contágio, a mescla, a mestiçagem, a fusão são inevitáveis. É uma identidade indefinida e conflitiva que perdeu suas características e, portanto, seu lugar no mundo.

É ai que Shepard encontra o modelo para o seu americano ideal que faz a terra trabalhar para ele e abraça os princípios fundamentais do caráter americano. As peças de Shepard revelam um personagem que é predominantemente construído de ilusão ao invés de realidade. Já que a identidade americana apresenta falsas imagens, permanecerá inacessível para os americanos que lutam desesperadamente para alcançá-la. É um paradoxo de identidade que levará os personagens de Shepard a engajarem-se num padrão contínuo de fuga e retorno, um ciclo infrutífero e auto-destrutivo o qual é utilizado na maioria de suas peças.

Neste capítulo, apresentamos a relação de Sam Shepard com uma tradição dramática específica, a americana, bem como sua incorporação crítica de temas e valores desta cultura - a crise da família, de um ideal de masculinidade, o lugar do sonho da bebida ; isto feito, embasada no percurso biográfico e estético esboçado no primeiro capítulo e nesta contextualização de sua obra no teatro americano moderno, passo a analisar a reverberação destes traços estilísticos e obsessões temáticas em três peças da vasta obra de Shepard.

\section{A desconstrução da família americana em três peças de Sam Shepard}

Escolhi para análise peças pertencentes ao núcleo familiar do teatro de Sam Shepard: Curse of the Starving Class, Buried Child e Fool For Love. As duas primeiras foram escritas em 1978, a terceira em 1983 e as três têm traços comuns que procuro evidenciar em análises cerradas de cada uma delas. Passo então à leitura de Curse of the Starving Class.

\subsection{Curse of the Starving Class: o ácido de Shepard corrói a América}

\subsubsection{Curse of the Starving Class - imaginando a América}

Essa peça foi encenada pela primeira vez no Royal Court em Londres em 1977, e recebeu um Obie. Ela é uma exploração cómica da psiquê da família americana; é um olhar expositivo de quatro membros da família Tate que vivem em uma fazenda da Califórnia. Os personagens mudam para adolescência, idade adulta e velhice, ao mesmo tempo que enfrentam a perda de sua fazenda devido a uma dívida. Weston é o pai 
alcoólico que afundou sua família em dívidas. Ella é a mãe que está buscando consolo fora de seu casamento e sonha em fugir para locais exóticos. A filha Emma tem planos de se tornar uma mecânica, e persegue projetos e fantasias a cavalo com a intensidade de uma adolescente. $\mathrm{O}$ filho Wesley procura uma maneira de manter sua família unida enquanto passa de um menino a um homem. Várias personagens secundárias são intercaladas na história, cada um tentando explorar a família e assumir suas terras. A peça examina a morte da família americana e suas dificuldades onde toda e qualquer compreensão mútua é perdida.

Shepard escolheu como lugar da ação uma fazenda de abacates no sul da Califórnia. O título reverbera através da peça como uma metáfora de fome espiritual, perda, necessidade de identidade individual, e um destino inevitável. A necessidade e busca por comida é constantemente simbolizada pelo refrigerador o qual, vazio ou cheio, atrai os personagens, mas não os sacia. Weston e Ella, e seus filhos Wesley e Emma, são vitimados parcialmente por trapaceiros e gangsteres, mas primariamente por eles mesmos e a doença que eles partilham. O resumo a seguir tem como objetivo facilitar a análise da peça.

O Ato I inicia com Wesley recolhendo os pedaços da porta da frente despedaçada. Num jogo oscilante de culpa e defesa centralizado em torno do ausente Weston, Ella revela que ela tem a intenção de vender a casa, a propriedade e tudo que estiver nela. Emma, frustrada por sua mãe ter cozinhado a galinha que ela criou para apresentar seu projeto na escola, tenta escapar do rancho no cavalo "louco" da família, mas é arrastada no barro. Quando Weston finalmente entra, bêbado, no final do ato, Ella partiu com o suposto advogado Taylor para negociar a venda da propriedade, e pai e filho confrontam um ao outro. Weston abastece o refrigerador com alcachofras, deixa sua roupa suja na mesa, e deixa seu filho sozinho na cozinha com o cordeiro que Wesley está tentando salvar das larvas de inseto que o infestam.

Wesley e Emma começam o Ato II sozinhos na manhã seguinte; nenhum dos pais retornou para casa. Weston entrou "consideravelmente mais bêbado que da última vez" (p. 163) e na cena seguinte, ele semeia ameaças e pistas sobre um desastre financeiro e desmaiando na mesa da cozinha. Ella retorna com compras, mas sem comentar sobre seu encontro da véspera. Ellis, o dono do Clube Álibi e reclamante da posse do rancho, chega logo atrás dela ele diz que Weston vendeu-lhe a propriedade por US\$1.500 em dinheiro vivo. Weston deve ter que pagar os trapaceiros de quem ele tomou emprestado dinheiro. Taylor, o qual acredita que ele somente precisa de mais uma assinatura de Ella para fechar o negócio, chega para completar a venda. Antes que Ellis, Taylor, e a família possam resolver quem possui o que, o sargento Malcom chega para informar aos pais de Emma que ela foi presa por ter atirado no Clube Álibi. Taylor escapa da presença do sargento Malcom frente às acusações sobre sua honestidade; Ellis, escritura e dinheiro em mãos, sai para ver seu clube, seguido de Wesley, determinado a recuperar o dinheiro. Ella (sozinha com o ainda inconsciente Weston) observa que "todos fugiram" (p. 181) antes que ela também parta. O Ato II termina com Weston, que acorda repentinamente, agora sozinho, olhando fixamente para o refrigerador.

O Ato III começa na terceira manhã. Weston está transformado: sóbrio, limpo, e responsável. Ele lavou as roupas, recuperou o cordeiro, e preparou o café da manhã. Wesley volta para casa "faminto" após sua tentativa fútil de recuperar os US\$1.500 e seu pai oferece a ele o café da manhã se ele se limpar. Ella volta para casa após passar a 
noite na cadeia; ela está exausta, chocada com a conduta de Emma, e descrente sobre a transformação de Weston. Incitada por Weston, Ella vai dormir na mesa, mas não antes de ver Wesley entrar, nu, e levar o cordeiro para fora do palco. Quando Wesley reentra, ele está vestindo as roupas sujas de seu pai. Wesley encoraja seu pai a reconhecer o perigo e desesperança da sua situação e sugere que ele escape para o México. Weston foge. Emma retorna declarando que está planejando uma vida de crime e começa pegando as chaves do carro e dinheiro da carteira da sua mãe, mas a explosão que segue a sua saída significa que ela não chegou além do carro. Emerson e Slater, que colocaram a bomba no carro, entram com uma mensagem para Weston, mas entregam-na para Wesley que veste as roupas de seu pai e também é chamado pelo seu nome. Sozinha com Wesley, Ella novamente o reconhece como seu filho, e os dois terminam a história de Weston, iniciada na abertura do ato, de uma águia e um gato no ar em combate mortal e caindo. "Como uma única coisa".

$\mathrm{Na}$ opinião de Hart, as imagens em Curse of the Starving Class "expandem em expressões simbólicas da destruição e desintegração do vínculo familiar" desta maneira criando um princípio estrutural na peça (p. 69). A águia e o gato, para Hart e para outros críticos, resumem os temas de Shepard. Ela escreve:

\begin{abstract}
A imagem na narrativa representa o laço familiar, a esposa e as crianças que dependem do pai, cuja fuga da responsabilidade leva junto com ele a família para destruição. Eles devem manter-se fiéis a ele em sua impotência, mas sua união o destrói e finalmente todos eles tombam juntos fatalmente unidos uns ao outros por uma casualidade biológica, seus destinos determinados pela sua interdependência com um laço familiar que não pode ser quebrado. (1987, p.
\end{abstract} 74)

As causas para "fuga de responsabilidade" de Weston, além da observação que elas representam alguma maldição hereditária ou uma condição impossível de livrar-se talvez comum a todas as famílias, não são consideradas por Hart.

Charles G. Whiting, em seu ensaio Food and Drink in Shepard's Theatre, examina o uso pelo dramaturgo de artigos de consumo como imagens, observando uma mudança na sua dramaturgia:

Não é, entretanto, até Curse of the Starving Class e Buried Child que Shepard desenvolve um conjunto de imagens visuais de comida para simbolizar desejos profundos por algum significado para vida. Álcool é o oposto das imagens de comida nessas peças porque expressa a frustração de um sonho. (1988, p. 180)

Incluindo True West and Fool for Love nessa discussão, Whiting foca no beber como uma atividade simbólica que divide ou une os personagens que partilham ou se recusam a partilhar bebida alcoólica. Ele comenta também os efeitos de transformação imediatos que a bebedeira causa nos personagens de Shepard. Como outros revisores ou críticos; Whiting descreve Weston como sendo um bêbado, mas a sua bebedeira crônica não se torna um tema.

O crítico britânico Thomas Adler ilustra a invisibilidade do alcoolismo na sua revisão da primeira representação londrina de Curse of the Starving Class:

Mais e mais, dramaturgos americanos [...] associaram a distorção e a morte do sonho americano com o fracasso de pais, de alguma noção distorcida de 
masculinidade, para prover sustentação emocional para suas famílias. Muito envolvidos com dinheiro, poder, sucesso, eles receiam ou são incapazes de dizer, sem levar em conta mostrar, que eles amam. (1977, p. 410)

O fracasso de Weston não deriva nem de uma situação nem de outra. Essa análise de Curse of the Starving Class foca na família como um sistema interativo ao invés de personagens individuais e seus papéis. Como Shepard os interpreta, os Tates são uma família envolvente, uma na qual o ego e as fronteiras de gerações são violados e a família partilha uma identidade grupal ao invés de ter personalidades individuais coerentes.

Não há possibilidade de intimidade em tal família porque não existem pessoas inteiras para nos relacionarmos. Cada uma dessas qualidades define a família do palco de Shepard em Curse of the Starving Class.

\subsubsection{A centralidade de Weston}

A bebedeira de Weston está além do seu controle e ela tem consequências negativas além de seus efeitos destrutivos serem demonstrados no palco e frequentemente são mencionados por outros personagens. Apesar de cada personagem falar da bebedeira de Weston de maneiras ligeiramente diferentes, essas diferenças em resposta, na realidade, ajudam a definir os papéis e relacionamentos na peça.

Wesley nunca usa as palavras alcoólatra ou alcoolismo, apesar de sempre reconhecer a bebedeira de seu pai e suas consequências. "Ele estava bêbado",

Wesley alega ao justificar o fato de seu pai quebrar a porta. Num monólogo longo, Wesley narra os sons terríveis da noite anterior antes do início da peça, uma noite incorporada na sua memória com outras noites aterrorizantes:

\footnotetext{
O meu ouvir estava amedrontado... meu coração batia rapidamente. Só de ouvir meu pai voltando... Ele está engessado e não pode se mover. Ele está engessado e não quer mover-se... Voz de homem. Na noite. O pé chutando forte através da porta. Um pé exatamente através da porta. O tinir de garrafas. Vidro quebrando. Punho através da porta. Homem amaldiçoando. Homem ficando louco. (SHEPARD, p. 137- 138)
}

Wesley e a mãe tratam a bebedeira de Weston como um fato a muito consagrado em suas conversas, mas apesar da bebedeira e violência onipresente, Wesley nunca denomina seu pai de alcoólatra.

É Ella quem na realidade chama a bebedeira habitual de Weston de alcoolismo. "Você não pode comprar uma propriedade de um alcoólatra!" ela diz para Ellis no Ato II, "Ele não é responsável por suas ações!" (p. 175). Ela censura, ameaça e culpa, mas continua a permitir que Weston beba. Por exemplo, ela diz para Wesley que trancou Weston para fora de casa porque "Eu disse a ele que da próxima vez que acontecesse eu trancaria a porta e ele poderia dormir num hotel" (p. 136). Ela responde a reivindicação de Wesley que seu pai trabalha na terra com o seguinte: "Quando ele não pode ficar de pé. O quão frequente isso acontece? Ele vem aqui e desmaia no chão por três dias e então desaparece por uma semana. Você chama aquilo de trabalho?" (p. 146). A resposta de Ella para transformação de Weston até mesmo inclui uma referência a Dr. Jekyll and Mr. Hyde, um trabalho que o terapeuta Charles Deutsch (1982, p. 41) chama "provavelmente a representação alegórica mais ilustre e imaginativa do alcoolismo na 
literatura". Entretanto, Ella permite que Weston beba diretamente ao prover comida para família e indiretamente ao encorajar Wesley a assumir as responsabilidades de Weston.

Da parte dela, Emma desculpa ou nega não somente o alcoolismo de Weston, mas a negatividade das suas consequências até a sua aparição final no Ato III. Ela fala ameaçadoramente com Taylor sobre o "pavio curto" do seu pai: "É químico. É a mesma coisa que o faz beber. Alguma coisa no sangue. Hereditariedade. Altamente explosivo" (p. 152). Ela também nega que Weston deve dinheiro a alguém: "Ele não deve um centavo! Tudo está pago!” (p. 154). Ela quer que ele acompanhe a família na mudança para Europa que a mãe está fantasiando. É Emma quem tenta corrigir os erros feitos a Weston quando ela atira no Alibi Club. Somente depois que seu pai foi realmente embora ela refere-se a ele negativamente, advertindo seu irmão: "Você vai terminar do mesmo jeito que ele! Doente!" e mais tarde, "Você é ainda mais nojento que ele. E isso é muito repugnante" (p. 195). O fato de Emma defender seu pai contradiz sua conduta para com ele; na presença de Weston, ela é temerosa e ponderada.

Os estranhos na peça também fazem julgamentos sobre a bebedeira de Weston. Apesar de Taylor, ser um advogado, ele é sem sombra de dúvida um vigarista e provavelmente um mentiroso, mas ninguém contesta sua descrição de Weston:

Temos evidência de primeira mão que ele é propenso a ataques de violência. Sua carta de motorista foi revogada, e mesmo assim ele continua dirigindo. Ele é incapaz de contratar um seguro. Ele é incapaz de manter um emprego fixo. Ele está ausente de casa noventa por cento do tempo. Ele tem antecedentes criminais. (SHEPARD, p. 178).

Como Ella, Taylor faz julgamentos morais sobre a bebedeira de Weston e procura tirar vantagem da sua condição. Outro estranho que fala sobre a bebedeira de Weston, mas não faz nenhum julgamento moral; Ellis, o dono do Alibi Club onde Weston passa "praticamente toda noite", diz: "Eu vivo dizendo para ele pegar leve, mas é como se eu peidasse no vento", adicionando mais tarde, "Eu vi alguns casos difíceis na minha época, mas ele é dedicado" (SHEPARD,p. 175).

Weston demonstra não somente seu vício, mas a também a desilusão que o acompanha. O público já ouviu e viu o suficiente antes de ele entrar (no Ato I) para acreditar que Weston cumpre nenhuma das suas responsibilidades familiares. Não obstante, ele repreende sua família ausente sobre ele ter que fazer tudo:

Fizemos isso novamente! Nós partimos e deixamos tudo para o velho novamente! As despesas de conservação! A manutenção! Perfeito!... Não existem mais milagres! Sem milagres hoje! Todos já foram usados! Sou somente eu! O Senhor Escravo trabalhador em pessoa que voltou para casa para reabastecer a dispensa vazia! (SHEPARD, p. 157).

Weston reabastece a dispensa completamente com alcachofras. Sua convicção que faz tudo, ou nada, do que é necessário para manter a família não é a única desilusão de Weston. Em cada uma das suas aparições na peça, ele faz ameaças ultrajantes e planos improváveis. Sobre o carro velho que sua esposa dirige ele diz, "Aquele carro era uma antiguidade. Valia uma fortuna" e reivindica que ele irá "quebrar a porra das costas do Taylor" se o carro for danificado (p. 165). Ele declara que matará tanto o Taylor quanto Ella com sua "arma capturada". Ele acusa Wesley de espioná-lo (p. 168, 169) e diz da 
família: "É como morar num covil de víboras! Espiões! Conspirações por trás das minhas costas! Estou sendo levado para dar uma volta por cada um de vocês!" (p. 169).

Na abertura do Ato III, quando Weston está sóbrio pela primeira vez na peça, ele ainda está delirante e nega os efeitos da doença em sua família. Ele diz para Wesley:

Você foi mimado, é só isso! Este é um paraíso para uma pessoa jovem! Existem jovens da sua idade que dariam a vida para crescer num meio ambiente como esse! Você tem tudo! Tudo! (SHEPARD, p. 192).

Wesley tem tudo exceto segurança, cuidado, atenção e auto-respeito. O Wesley sóbrio sinceramente acredita que seus problemas, os quais ele vagamente recorda, desaparecerão porque ele é "uma pessoa completamente nova". Ele diz para Wesley:

Eu não tenho que pagar pelo meu passado agora! Não agora! Não depois dessa manhã! Tudo aquilo está para trás agora! Você me entende? Tudo terminou porque eu renasci! (SHEPARD, p. 192).

A única referência de Weston à sua própria bebedeira ocorre no Ato III e é indireta ou é uma negativa. Por exemplo, quando Ella pergunta como ele pode dormir na cadeia local, Weston responde, "Se você está entorpecido o suficiente que até não sente nada" (p. 190). Quando Ella recusa-se a aceitar seu renascimento ("Bem, você pode livrar-se daquela tolice porque eu não acredito nela!), Weston responde: "Você gostaria de café?" (p. 189). Ao ignorar o ceticismo de Ella sobre sua nova identidade sóbria, ele nega sua natureza alcoólatra anterior. Similarmente, Weston também a nega ao trocar a propriedade das suas próprias roupas descartadas após Wesley vesti-las: "Você vai e toma um banho e depois veste as roupas de algum beberrão velho que foram vomitadas, urinadas, e Deus sabe o que mais?". Deus pode saber, mas Weston provavelmente não se lembra. Quando Wesley confronta Weston sobre sua perda da casa procede o seguinte diálogo:

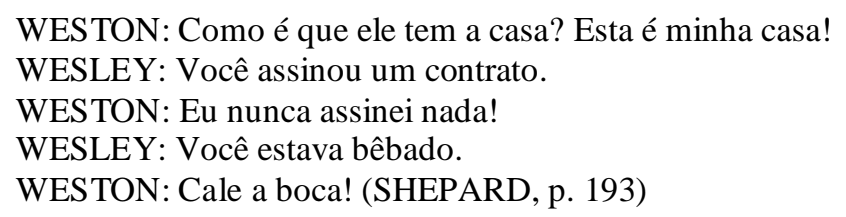

Apesar da conversa continuar e Weston acabar admitindo que irremediavelmente deva para homens perigosos, nada mais é dito sobre álcool.

Enquanto os críticos identificam Wesley como protagonista de Curse of the Starving Class, é a presença ou ausência de Weston que é a maior parte das vezes o tema central para os personagens. No palco, ele é o foco constante da família, até mesmo quando ele está desmaiado na mesa no Ato II; ele é o agente primário com o qual, os outros reagem. Até mesmo quando ele está fora do palco, a centricidade de Weston é óbvia. Na cena de abertura entre Ella e Wesley, Weston é o principal tópico da conversa, mas as primeiras referências a ele são feitas somente pelo pronome pessoal "ele", dando proeminência misteriosa ao personagem não nomeado: "Ele deveria estar fazendo isso. Ele foi o que a quebrou. Ele não está aqui. Ele voltará". (SHEPARD, p. 134 - 135)

Ella, apesar de não dizer nada de positivo sobre Weston para ninguém mais, claramente o considera como o centro da existência continuada da família. A decisão dela de 
vender a fazenda e escapar para Europa, uma das muitas fugas geográficas planejadas pelos personagens, é estimulada pela ausência de Weston. Para ela, aparentemente, a casa não é um lar sem ele:

ELLA: Não estou falando sobre manutenção. Estou falando sobre consertála.

Fazer com que pareça que alguém mora aqui. Você faz isto?

WESLEY: Alguém mora aqui!

ELLA: Quem! Não o seu pai! (SHEPARD, p. 146)

Seja lá o que Emma e Wesley pensem, ou o que nós como platéia ou os críticos decidam, Weston também acredita que a decisão de Ella de vender o lugar origina-se da sua ausência. Ele diz: "Ela deve ter pensado que eu estava morto ou algo parecido. Ela deve ter pensado que eu nunca voltaria" (SHEPARD, p. 195).

Weston e Ella aparecem juntos brevemente no palco e ambos acordados no Ato III. Apesar de Ella suspeitar da transformação dele, como mencionado acima, o diálogo entre os dois inclui os momentos mais razoáveis dela e é para Weston que ela realmente faz o único elogio na peça: "Você deveria ter sido um pregador... Você tem uma excelente voz. Profunda. Ressoa" (p. 190). Ela aceita a sugestão dele para dormir em cima da mesa. Duas noites antes ela havia "chamado os tiras" para protegê-la porque ela afirmou: "Eu estava correndo perigo de vida. Eu estava sendo ameaçada" (p. 136). Sobriedade e bebedeira são bem diferentes: Ella transformou-se porque Weston também se transformou.

Durante a peça, os personagens assistem e esperam por Weston, invocam-no quando ele não está presente, e permitem que ele domine a ação quando ele está. Ella e os filhos demonstram não somente fascinação em relação a Weston, mas também medo dele. No Ato II, por exemplo, quando Wesley adverte sua mãe para não acordar Weston, ela responde, "Eu não estou mais andando na ponta dos pés. Eu acabei com o sentimento de ser uma estrangeira na minha própria casa. Eu não tenho mais medo dele" (SHEPARD, p. 173). Entretanto, ela não é bem sucedida em acordá-lo.

Enquanto a conduta de cada um dos personagens muda quando Weston está no palco, as mudanças de Emma são as mais óbvias. Quando o pai dela está ausente, Emma é ativa, articulada, determinada e aparentemente destemida, tentando escapar da família no cavalo imprevisível, por exemplo, e dizendo para mãe dela que a cooperação é "fatal. Direciona-nos para morte" (p. 139). Emma frequentemente fala sobre Weston e inevitavelmente o defende, por exemplo, Emma traz Weston para dentro de sua cena com Taylor, usando a propensão de Weston para violência como uma ameaça: "Ele tem um temperamento terrível. Ele quase matou um cara que ele pegou com ela" (p. 152). Emma acredita (ou simplesmente diz que acredita) que o pai dela "pode voltar para casa a qualquer segundo agora" (p. 152). No Ato II, ela pergunta para Wesley por que ele não disse para ela que seu pai havia voltado para casa na noite anterior e ela defende a sacola de Weston cheia de alcachofras, mas quando ele chega, ela está claramente com medo dele. Shepard nos esclarece com a seguinte rubrica:

(Weston tropeça de repente do lado direito do palco. Ele está consideravelmente mais bêbado que da última vez. Emma está de pé ao lado da mesa, sem saber se fica ou sai. Weston olha para ela.) 
WESTON: (para Emma) Apenas relaxe. Relaxe! É somente o seu velho. Sente-se!

(Emma senta-se...) (SHEPARD, p. 164).

Alguns minutos mais tarde, "([Weston] tropeça em direção à mesa e senta no final do palco do lado direito. Emma levanta-se) Weston: (para Emma) Sente-se!” (p.165). Emma foge do palco logo depois que as suas boas intenções foram destorcidas pela recusa de Weston em deixá-la lavar a roupa e seus sentimentos foram magoados pela sua referência sarcástica a sua perseverança como aluna: "Seu irmão nunca foi um crânio, foi? Você sempre foi a mais inteligente. Você é a aluna nota 10, não é mesmo?" (p.166). Logo após essa fala ele anuncia que Emma deveria achar algo melhor para fazer porque ele encontrou um comprador com dinheiro para comprar "esta lixeira". Ele "bate na mesa com sua mão", e Emma se levanta e sai.

As tentativas de Emma de intuir e fazer qualquer coisa que Weston quer que ela faça são menos bem sucedidas na prática, mas similares no espírito, às do seu irmão. Wesley está mais propenso, e mais capaz, de manobrar seu pai; entretanto, ele também é temeroso e cuidadoso. Os barulhos inconfundíveis que sinalizam a primeira entrada de Weston induzem Wesley a sair correndo da cozinha e esperar até que ele possa avaliar o estado de espírito de seu pai.

Quando ele entra, Wesley principalmente faz perguntas sobre as alcachofras, sobre a terra que seu pai afirma possuir no deserto e concorda com os pedidos e sugestões do seu pai. $\mathrm{Na}$ atmosfera mais perigosa do Ato II, Wesley, que "fica de pé desajeitadamente", enquanto Weston ordena que Emma se sente, é censurado por seu pai: "Não fale com sua voz no fundo da sua garganta como se você fosse uma minhoca! Fale com os seus dentes! Fale!"' (SHEPARD, p. 164).

Weston não é um fator em somente duas cenas significantes da peça e em cada uma delas, Wesley parcialmente assume o papel de seu pai. A primeira cena ocorre no Ato I e prefigura a segunda. Quando Emma traz o seu projeto no qual ela trabalhou arduamente, ela descobre que a galinha que ela precisa para sua demonstração sumiu, aparentemente foi cozida por sua mãe. Ela está compreensivelmente irada e bastante capaz de expressar-se, mas é comandada por Ella para fazê-lo "do lado de fora"; a maior parte dos atos significativos de Emma ocorre fora do palco, na realidade. Assim que Wesley compreende a situação, "ele baixa o zíper da braguilha, tira seu pênis para fora, e começa a urinar sobre o gráfico no chão" (p. 142). Ele está como ele reivindica "abrindo novas possibilidades para ela. Agora ela terá que fazer alguma outra coisa" (p. 143). Esse é um Wesley muito diferente daquele que tenta consertar a porta e salvar o cordeiro, mas o mesmo jovem rapaz que mais tarde veste as roupas de seu pai e abate o mesmo cordeiro.

A suposição de Wesley sobre o lugar do seu pai no sistema familiar, enquanto não inclui bebida, evoca condutas associadas com bebedeira: seu urinar no gráfico de Emma o qual prevê a observação de Weston sobre as roupas molhadas de urina; sua conduta extravagante no Ato III que induz seu pai a lhe perguntar se ele estava bêbado (p. 184). O medo e a prudência que caracterizam os encontros pai/filho nos dois primeiros atos invertem-se no III. Shepard inclui as seguintes direções de palco: "(Weston o observa, um pouco temeroso do estado de Wesley... Weston move-se cuidadosamente, para longe de Wesley e para o lado direito do palco)" (SHEPARD, p.191). 
O fato de Shepard colocar o relacionamento Weston/Wesley em primeiro plano em Curse of the Starving Class representa uma linha percorrendo sua completa carreira. Mottram afirma:

\begin{abstract}
A imediata linhagem de Curse of the Starving Class pode ser rastreada até a primeira peça sobrevivente de Shepard, The Rock Garden, e através de todas suas peças que lidam com relacionamentos pai/filho, especialmente The Holy Ghost. (1988, p. 132)
\end{abstract}

A forma como Shepard escreve os relacionamentos pai/filho é central para suas construções do que significa ser um membro de uma família em cada uma de suas peças familiares. Fundamentado em sua própria experiência, a busca de Shepard consequentemente cria múltiplos retratos de uma família americana. Os filhos que lutam contra sua "herança" são substitutos para o dramaturgo e consequentemente, habitam os centros das peças com seus pais, os centros das famílias no palco. A centralidade desses personagens explica, em parte, a marginalização das mulheres nas peças familiares de Shepard e a sua criação do que Doris Auerbach chama de "uma série de figuras maternais que são muito fracas para neutralizar a violência dos pais" (1988, p. 53).

Numa família real organizada nitidamente em torno de um membro, todos os outros marginalizam a si mesmos. O fato de que os personagens alcoólatras nessas peças serem do sexo masculino, geralmente o pai, e dado o caráter autobiográfico ou ponto de vista interno que os críticos atribuem ao dramaturgo, faz com que as mulheres sejam relegadas para as margens da ação.

Somando-se à centralidade desses personagens e sua conduta, Deutsch (1982, p. 31). cita outras quatro características da família nessa peça: "negação e vergonha; inconsistência, insegurança, e medo; raiva e ódio; e culpa e censura". Cada uma dessas condições é abundantemente demonstrada em Curse of the Starving Class.

A vergonha que a família sente em Curse of the Starving Class é raramente articulada e então somente quando um incidente particular, geralmente envolvendo pessoas de fora da família, provoca sua menção. A objeção de Wesley em relação a sua mãe chamar a polícia, por exemplo, é que: "É humilhante quando os tiras vêm até sua casa. Faz-me sentir como se eu fosse outra pessoa... Faz-me sentir solitário. Como se nós estivéssemos com problemas ou algo parecido" (p. 137). Wesley está tão condicionado ao medo e violência que ele está prestes a descrever em seu monólogo que somente a presença da polícia faz a ocasião memorável. A resposta rápida de Ella, "Nós não estamos com problemas. Ele está com problemas, mas nós não", nega que ninguém está doente somente Weston, uma negação que se torna cada vez mais irônica conforme a peça progride porque, claramente, todos os membros da família estão com problemas separadamente e juntos.

No Ato III, quando Ella retorna da cadeia e enumera as acusações contra Emma para Weston, ele parece mais orgulhoso dela do que em qualquer outra ocasião, induzindo Ella a dizer, "Bem, estou contente que você encontrou uma maneira de transformar a vergonha numa fonte de orgulho". Weston responde: "O que é vergonhoso sobre isso? Precisa-se de coragem para ser acusado de todas aquelas coisas. Não são todas as pessoas da idade dela que podem acumular uma lista de créditos como aquela" (p. 188). 
Para Weston, tudo é evidência de que Emma é parte da sua "linhagem familiar", que ela também tem nitroglicerina "no sangue", assim como Emma o descreve para Taylor.

A inconsistência das personagens em Shepard é uma das características mais marcantes não somente em Curse of the Starving Class, mas na maioria dos seus trabalhos. Enquanto seus personagens passam por rápidas mudanças são frequentemente consideradas pelos críticos como transformações teatrais do tipo praticadas pelo Open Theatre, inconsistência é outra característica nas famílias das peças. As transformações mais óbvias, e como consequência as inconsistências mais radicais em Curse of the Starving Class, são as de Weston e Wesley. Ninguém na família, entretanto, tem uma conduta consistente.

A primeira indicação para a platéia de que essas pessoas mudam repentina e aparentemente sem provocação, ocorre na primeira cena da peça. Ella justifica que chamou os policiais, pois temia por sua vida, que ela estava incerta sobre quem estava tentando invadir a casa, e então que ela podia cheirar a pele de Weston "através da porta", reivindicações que nelas mesmas são inconsistentes e contraditórias. Então, "Ella: (de repente alegre) Você quer seu café da manhã?" (p. 138). Quando Ella muda o assunto e começa cozinhar, Wesley, que defendia o pai, ou ao menos culpava sua mãe, relata sua própria narrativa do violento regresso ao lar de seu pai.

O que parece ser uma mudança de atitude sem base, aqui e em qualquer lugar na peça, segue um padrão: se um membro da família está censurando alguém, os outros o defendem; se um recusa responsabilidade, o outro a aceita; se um personagem encara a realidade, o outro fantasia. É a consistência do padrão, o equilíbrio do sistema, que é crucial na família, mais do que a consistência do personagem, essa necessidade de equilibrar o sistema que acaba transformando Wesley.

Insegurança também permeia a peça. Qualquer tipo de segurança física que tenha desaparecido da família, ao menos simbolicamente, com a porta da frente. Segurança financeira também não existe. Para os filhos, existe a insegurança óbvia de morar numa casa a qual pai e mãe estão tentando vender e enquanto a perda ou a venda da casa pode não ser assustadora em si mesma, é o abandono que os ameaça. Wesley acusa Ella de planejar abandoná-los: "E você vai partir com o dinheiro sem contar para ninguém?" (p. 145). No Ato II, irmão e irmã têm a seguinte conversa:

EMMA: (depois de uma longa pausa) Você acha que eles vão voltar? WESLEY: Quem?

EMMA: Nossos pais.

WESLEY: Quer dizer que nunca? (SHEPARD, p. 163)

Já que nenhum dos pais acaricia os filhos, a presença dos pais faz pouco ou nada para amenizar suas inseguranças.

Raiva e ódio são tão inevitáveis na peça quanto a violência. As acusações, as ameaças, as fantasias de vingança todas os transmitem. Shepard também indica um freqüente gritar tanto nas suas direções para o palco quanto nos diálogos escritos com letras maiúsculas. Quando a raiva é expressa em Curse of the Starving Class, é frequentemente inconsistente ou deslocada. Ninguém, por exemplo, expressa raiva em relação ao fato de Weston ter destruído a porta da frente e somente Ella parece ter ficado brava com ele por vender a casa para Ellis. Emma, enquanto ela está furiosa com 
a mãe por ter cozinhado a sua galinha, não expressa nenhuma raiva por seu irmão ter arruinado seu gráfico. $\mathrm{O}$ ódio é ainda mais fragmentado, submerso, e mal direcionado do que a raiva.

Os pais e filhos em Curse of the Starving Class não conseguem expressar abertamente seu ódio, mas o seu negar e submergir têm profundas consequências. A descrição de Deutsch dessas consequências sincroniza as várias passagens na peça nas quais os personagens referem-se à maldição familiar:

Eles estão genuinamente inconscientes que eles odeiam seus pais (ou cônjuges). Alguns direcionam sua raiva para seu íntimo. Outros sentem uma ira interior desamparada e generalizada, e que um sentido de privação, injustiça, e crueldade são as regras da vida, ou em qualquer evento, a porção deles, agora e para sempre. (1982, p. 46)

A resposta de Ella para as notícias que não está em liberdade, que Weston vendeu a casa antes que a negociação dela consuma-se, expressa desesperança que resulta de ódio negado:

É uma maldição. Eu posso senti-la. É invisível, mas está lá. Está sempre lá. Vem sobre nós como se fosse a noite. Todo dia eu posso senti-la. Todo dia eu posso vê-la caminhando em nossa direção. E ela sempre vem. Repete-se. Ela vem mesmo quando você faz tudo para impedi-la. Até mesmo quando você tenta mudá-la. (SHEPARD, p. 174)

$\mathrm{Na}$ linha remanescente, Ella descreve essa maldição como hereditária, o quinhão da família agora e para sempre, e endêmica em todas as espécies.

A desesperança dos personagens, o desamparo deles para superar ou escapar sua ira, e "o senso de privação, injustiça, e crueldade" que permeia a peça recebe menção crítica frequente. Como Ella, os críticos vêem isso como uma condição "universal" ou nacional mais do que uma específica desta família ou para qualquer outro tipo de família. Na opinião de Ron Mottram:

Curse of the Starving Class generaliza seus assuntos ao usar a condição da família como uma metáfora para condição humana nela mesma, a qual condena todos a serem um portador e transmissor do veneno de gerações passadas. (1988, p. 132)

Rudolph Erben acredita que Shepard está dramatizando "A sociedade americana, com seu impacto destrutivo no indivíduo (masculino)" (p.36, 1987). Na visão de Erben, o casamento e as mulheres constituem o 'aprisionamento da civilização', e a família que é uma "maldição" é passada de pais para filhos". (p. 36, 1987). A análise de Erben faz de Weston uma vítima completa da ganância de Taylor em especulação imobiliária e da voracidade de Ella.

O padrão de censura e correspondente negação que caracteriza a família é evidente na peça, apesar da censura, assim como a raiva, é raramente direcionada a Weston exceto por Ella. Deutsch (1982, p. 45) explica como esse mecanismo em particular funciona: "[filhos] não podem controlar a violência do pai, mas podem censurar e ressentir-se como se fosse uma provocação qualquer coisa que um dos pais ou dos irmãos fazem". Na cena de abertura, Wesley culpa sua mãe por seu pai ter quebrado a porta; Ella é na realidade o alvo da censura frequente. Bêbado, Wesley alega que não poderia esperar 
que seu pai lidasse com a porta trancada de uma maneira não violenta. A hipótese não falada é que ele não deveria ter sido colocado na posição de lidar com esse fato.

Wesley, democraticamente, censura Emma ao invés da sua mãe por ter cozinhado a galinha, dizendo "CALE A BOCA! VOCÊ DEVERIA TER POSTO SEU NOME NA GALINHA SE VOCÊ NÃO QUERIA QUE ALGUÉM A COZINHASSE!” (p. 141). O padrão de censura e defesa é consistente; assim como Wesley censura sua irmã, Ella a defende explicando os meandros do projeto de Emma.

Às vezes, na peça, os personagens unem-se em censura e defesa. Como Deutsch observa: "Violência por parte dos pais pode unir os filhos contra um inimigo em comum..." (p. 45). No Ato II, quando Weston questiona seus filhos sobre o paradeiro de sua mãe, eles são circunspectos em suas respostas, parcialmente porque eles realmente não sabem onde Ella está, e parcialmente porque eles estão receosos da reação de Weston. "Não me venha com essa! Não tente me enganar!", afirma Weston (p. 164). Seu diálogo transmite que esta é a última de muitas tentativas de proteção mútua. Weston "começa a ir atrás de WESLEY" e exige, "Não tente protegê-la!..." (p.164-165). Emma entra em defesa de Wesley ao divulgar que a mãe "saiu com o advogado", e depois ela tenta inventar desculpas para a ausência contínua de Ella dizendo "Talvez eles se acidentassem" (p. 165). Como no seu presente estado Weston não se lembre do que é um advogado, e porque ele está mais preocupado com seu carro do que com sua esposa, os filhos são bem sucedidos em neutralizar sua raiva.

A linguagem da peça, tanto na forma quanto no conteúdo, demonstra comunicação previsível como Deutsch (1982, p. 56) o descreve:

O padrão governando o evento central da família, o beber, e o informar qualquer comunicação é que enfraquece a noção de que as palavras têm significado. Os filhos ouvem o pai [ou a mãe] que não é alcoólatra repetidamente ameaçar que vai partir, ainda assim ele [ou ela] não vai embora; eles ouvem o alcoólatra chorando jurar que vai parar de beber, ou que parou de beber; e eles ouvem todos os tipos de palavras ditas em períodos de bebedeira e raiva. Palavras são usadas principalmente para magoar ou manipular; quando elas são usadas para expressar sentimentos reais, elas são abatidas ou desanimadas. Ação e silêncio substituem as palavras como principal meio de comunicação dentro da família. Mensagens são consequentemente ambíguas e indiretas.

Essa ambiguidade e não objetividade é identificada por Mottram como: "Mentiras; pensamentos, sentimentos, e palavras existindo num vácuo; ausência de qualquer contato ou compreensão..." (1988, p. 134). A descontinuidade entre o que é dito e o que é mostrado como marcas verdadeiras praticamente em toda cena da peça. Para dar um exemplo, o pai e a mãe enfatizam a juventude de Emma num momento e em outro insistem que ela pode ou deve imediatamente encontrar seu caminho no mundo sem eles.

Phyllis R. Randall (1988), em seu artigo "Adaptando-se a Realidade: Linguagem em Curse of the Starving Class" relaciona o diálogo a outros de outras peças do início da carreira de Shepard. Ao fazê-lo ela observa:

No início da peça [Shepard] salienta, até mesmo enfatiza, algumas normas de conversação. Ele parece fazê-lo, a meu ver, com a intenção de fazer um 
contraste pontual da conversa a seguir com menos que lógica, diferentemente do normal. (KING, 1988, p. 124)

A análise de Randall da conversa ilógica e anormal foca na linguagem como um atributo do personagem enfatizando diferenças mais do que similaridades entre os personagens em Curse of the Starving Class. As mudanças de voz de Weston e Wesley são vistas como consequências da transformação deles enquanto que as descontinuidades de Emma originam-se da sua idade: "[ela] tem mudanças repentinas de temperamento, assim como contrastantes mudanças de temperamento entre ser adulta e criança" (p. 123). Randall acredita que Ella fala como duas pessoas por causa da sua "natureza contraditória", uma natureza indicada por suas mentiras e sua "conduta não maternal" (p. 128). As diferenças influenciadas dos personagens que Randall observa com certeza existem, mas as generalidades de comunicação da família são mais numerosas que suas diferenças. Quando emoções reais encontram manifestação na peça, a censura de Emma sobre a galinha ou o monólogo de abertura de Wesley, por exemplo, o locutor está distanciado ou é ignorado. Ao invés de comunicar, cada um dos personagens usa palavras como armas para acusar, atacar, ou censurar; cada um defende a si mesmo com evasivas ou mentiras; cada um deles escapa em fantasias verbais do que eles não conseguem escapar fisicamente.

Em Curse of the Starving Class cada personagem planeja uma fuga, uma cura geográfica, em se mantendo dentro dos padrões de comunicação familiar, cada fantasia é ridicularizada ou ignorada. A fantasia de Ella é a "Europa talvez... Eles têm tudo na Europa. Arte. Pinturas. Castelos. Prédios. Comidas extravagantes.”. Wesley responde, "Eles tem tudo isso lá" (p.143). Levando em conta o atoleiro financeiro em que a família se encontra, a esperança de Ella vender o lugar é nela mesma, uma fantasia. O ideal de Wesley de escapar é "Alasca, talvez":

EMMA: O que há no Alasca?

WESLEY: A fronteira.

EMMA: Você está maluco? Está tudo congelado e cheio de estupradores.

WESLEY: Está cheio de possibilidades. Não foi descoberto.

EMMA: Quem quer descobrir um monte de gelo? (SHEPARD, p. 163)

As fantasias de Emma são as mais desenvolvidas no palco. Na sua narrativa mais longa no Ato II, ela expande sua ideia de se tornar uma mecânica no México ao incluir que enganou sua mãe e Taylor cujo carro vai quebrar e deixá-los a mercê dela. A resposta de Wesley para seu enredo é: "Se você não está fazendo nada, você poderia verificar as alcachofras?" (SHEPARD, p. 162).

No nício da peça, Weston também cogita a idéia de escapar para o México, mas quando é forçado a ir, ele não mais quer fazê-lo: "Eu não posso partir e deixar tudo para trás... porque é aqui que estou estabelecido! Aqui é onde a linha termina! Bem aqui! Eu emigrei para este local! Não tenho nenhum lugar para ir! É isso aí!” (p. 193). Como Emma observa, o México para o qual ele está escapando não é o México das fantasias deles: "México, hem? Ele não vai durar um dia lá" (SHEPARD, p. 195). Os filhos estão protegendo os pais e existe um papel reversível com um dos filhos que aparece no papel de um dos pais, essas características são as mais óbvias na peça. 
O cenário de Shepard provê, em parte, o isolamento necessário à negação e mascaramento da vergonha. Esse isolamento é enfatizado pela distância entre os membros da família e dos de fora do círculo familiar. No Ato I existe o seguinte confronto entre Taylor e Emma:

TAYLOR: É uma sensação engraçada.

EMMA: O quê?

TAYLOR: Eu sinto como se estivesse em território inimigo.

EMMA: E você está. (p. 153)

A necessidade de permanecer isolado, recolocar-se e escapar é expressa por cada um dos personagens. Como Deutsch nos faz relembrar: "Esse tipo de família é frequentemente nômade virtual numa sociedade geralmente móvel [...] Eles procuram por soluções 'geográficas'[...]" (1982, p. 25). Em Curse of the Starving Class essas soluções geográficas tornam-se o foco das fantasias para cada um dos personagens, uma das características partilhadas que demonstram seu enredo.

Tanto o pai de Weston quanto o de Ella são mencionados na peça e o retrato que Weston faz do 'meu velho' e o veneno que infectou ambos é evidência do padrão herdado. Weston diz para Wesley:

\begin{abstract}
Eu nunca vi o veneno do meu velho até que eu era bem mais velho que você. Bem mais velho. E você sabe como eu o reconheci? [...] Porque eu vi a mim mesmo infectado por ele. Foi assim. Eu me vi carregando-o por ai. O veneno dele no meu corpo [...] (SHEPARD, p. 167)
\end{abstract}

Weston não pode, ou não dirá a Wesley qual é o veneno; ele sugere que Wesley somente irá descobrir sua natureza quando ele mesmo estiver infectado.

A família de Ella também é mencionada; Weston acredita que a família dela pertencia a uma classe diferente da sua: "Artistas" ou "Profissionais. Ninguém levantou a voz" (p. 188). A referência de Ella ao próprio pai é desagradavelmente sugestiva de incesto:

ELLA: Por que você não é sensível como seu avô era? Eu sempre pensei que você era igualzinho a ele, mas você não é, é?

WESLEY: Não.

ELLA: Por que você não é? Você é circuncidado como ele. É praticamente idêntico na verdade.

WESLEY: Como você sabe?

ELLA: Eu olhei. Olhei ambos e pude ver a similaridade. (p. 143 - 144)

Seja qual for o relacionamento físico entre Ella e Wesley, ele serve como um esposo substituto para a mãe e como um pai substituto para Emma. A coalizão entre gerações sugerida entre Wesley e sua mãe e também sugerida entre Ella e o pai dela são típicas e indicativas do enredo.

O reverso de papéis que caracteriza essa família é notório em Curse of the Starving Class. Críticos de peças familiares, entretanto, geralmente caracterizam-na somente como fracasso paterno ou materno. Auerbach (Casebook, 1988, p.54) afirma: "A família que Shepard descreve repetidamente é aquela que não pode nutrir seus filhos, que se tornou tão infrutífera e estéril quanto o traído sonho do oeste americano". Marranca concorda: "Os pais são mostrados como figuras patéticas, cômicas e sonhadoras, incapazes de compreender ou iniciar eventos. Eles são fracassos como 
figuras maternas ou paternas, com mais problemas e mais sem controle que seus filhos" (American Dreams, 1981, p. 16). A família em Curse of the Starving Class espelha uma estrutura familiar de fracasso ou abdicação paternal e/ou maternal que será acompanhada da apropriação das responsabilidades e papéis dos pais pelos filhos.

Dos momentos iniciais da peça, fica claro que Wesley tenta proteger seu pai. Nas suas cenas conjuntas, além de acalmar seu pai, Wesley frequentemente parece ansioso sobre o bem estar dele. Quando pergunta onde seu pai está indo, no Ato I, Weston responde: "Não se importe onde estou indo! Eu posso tomar conta de mim mesmo" (p. 159). É um esforço para proteger Weston e o resto da família das consequências do seu empréstimo descuidado. Quando Weston transforma-se, entretanto, Wesley fica desnorteado, ao invés de feliz, e belicoso, ao invés de solícito. Ele pode somente reagir como um pai atencioso quando ele tem um filho agindo como pai com o qual ele pode reagir.

A posição 'adulta' de Wesley, desvirtuada pelo seu monólogo de abertura, é parcialmente explicável por ele ser um adolescente mais velho; entretanto, suas responsabilidades estão fora de proporção para sua idade. Wesley é responsável pela manutenção da terra e dos animais; por cuidar do pomar, alimenta as ovelhas, irriga a terra (p. 146); ele sabe, mas seu pai não, quantas ovelhas gêmeas nasceram (p. 159). Como esposo substituto, Wesley é confidente de Ella em seu plano para vender o lugar; ela até oferece para levá-lo junto. Quando Wesley veste as roupas de seu pai, e com elas o personagem de seu pai, no final da peça, Ella o chama pelo nome do pai: "Tire esses homens daqui Weston! Eles estão na minha cozinha." "Vá buscá-la, Weston! Ela é sua filha! Ela está tentando escapar!” (SHEPARD, p. 197 -198).

Por toda a peça, é para Wesley que Ella repassa Emma e o seu cuidado. No Ato I, quando Ella diz para Wesley para impedir sua irmã de montar aquele cavalo 'insano' e Wesley recusa, Ella abandona o projeto: "Bem, talvez ela fique bem" (p. 144). Ela está claramente indisposta, ou incapaz, de tomar conta da própria filha. Quando Ella parte com Taylor, ela alerta o filho, "Mantenha os olhos bem abertos com Emma, Wes. Ela carrega a maldição. Você sabe como é isso para uma garota, quando é a sua primeira vez" (p. 155) Wesley, naturalmente, não tem a mínima idéia, como Ella dá uma informação errada para sua filha na primeira cena conjunta das duas, deduzimos que Emma também não tem a mínima idéia.

Emma também frequentemente assume um papel maternal, enquanto Ella comporta-se infantilmente, o que fica claro na seguinte passagem na peça:

\author{
Voz de EMMA: VOCẾ É UMA PIRRALHA MIMADA! \\ Ella: (para Wesley) Você ouviu do que ela me chamou? (ela percebeu o que ele \\ estava fazendo, ela grita para Emma) EMMA! \\ Voz de EMMA: O quê? \\ ELLA: SEU IRMÃO ESTÁ URINANDO NOS SEUS TRABALHOS! (volta a \\ comer). (SHEPARD, p. 142)
}

Ella tagarela, primeiro com um dos filhos depois com o outro, mas não faz nada para sancionar ou parar a conduta ultrajante de Wesley. As referências de Emma para sua mãe, aqui e em qualquer lugar, geralmente soam mais como pronunciamentos de um pai ou mãe do que de uma criança. Falando de sua mãe, Emma diz par Taylor: "Ela não é uma mulher de negócios. Ela é terrível nos negócios", "Ela é estúpida. Ela acreditará em qualquer coisa" (p. 151); como sempre é o caso, os julgamentos de Emma são precisos. 
As reações de Emma aos seus pais, enquanto eles são adolescentes, são claras. O antagonismo dela em relação a sua mãe é marcado, assim como sua necessidade de defender ou agradar seu pai. A defesa de Weston requer negação absoluta, "Ele não tem um centavo", e significativo delírio, "Nós poderíamos ocupar [a casa]. O pai tem uma arma" (p. 163). Emma tenta, no segundo ato, assumir a responsabilidade pela lavagem das roupas de sua mãe ausente, mas sua última tentativa de proteger um dos pais e sua cavalgada armada através do Álibi Club, a única ação que recebe um elogio do seu pai.

A transição de Emma para feminilidade, o início da menstruação, é referido como "a maldição". Enquanto que a expressão é antiga, o fato de Shepard usá-la comunica uma repugnância pelo novo estado de Emma que a família expressa diretamente. A resposta de Weston para as notícias de Emma "está menstruada pela primeira vez", é: "A primeira o quê? Ela é muito nova para isso. Isso não é para acontecer quando elas são dessa idade. É prematuro" (p. 166). Ella dá um mínimo de informação desencontrada sobre menstruação para sua filha e depois a deixa aos cuidados do irmão.

O título da peça é sempre mencionado pelos revisores, críticos, e pelos personagens. Alguns o vêem como significando a necessidade dos membros familiares por identidade (GILMORE, 1987), ou como um slogan vilipendiando a perda do American dream (BLAU, 1982). Enquanto podemos considerar ambas as razões, também representa a identidade do grupo da família confusa. Eles definem a eles mesmos pelo que eles não são: "Emma: [para Ella] NÓS NÃO PERTENCEMOS A CLASSE FAMINTA!" (p. 142); "Wesley; (para a ovelha) Você tem sorte que eu não estou realmente esfomeado. Você tem sorte que essa é uma casa civilizada" (p. 156); "Ella: [para Wesley] Como você pode estar faminto o tempo inteiro? Não somos pobres. Não somos ricos, mas não somos pobres" (p. 143); "Weston: [para Wesley] Você não poderia estar tão faminto!... Já vi pessoas famintas na minha época, e não estamos tão mal!” (p. 192). Que eles estão famintos, por contato humano significativo, por segurança, por amor, é dolorosamente óbvio. Nem Weston, que volta para casa "para abastecer a dispensa vazia!" (p. 157), nem Ella quando ela enche o refrigerador com comida, pode satisfazer algumas dessas necessidades. Não importa o quão ruidosamente ou frequentemente a família proteste, a identidade deles é uma ilusão; eles são parte da classe esfomeada.

A falta de identidade individual, de claros limites de ego, entre os membros da família é expressa até mesmo pelos seus nomes. Rodney Simard (1984, p. 85) observa: "Como é sugerido pelos nomes deles, Wesley e Emma são simples variações, ou variantes, dos nomes dos pais, Weston e Ella". A identidade do grupo, a confusão dos papéis dos filhos com os dos pais, as identificações entre gerações e coalizões na família todas produzem evidência do enredamento familiar. Os comentários de Weston e Ella sobre os pais deles implicam que tal enredamento é parte de um padrão multigeracional.

Um tema recorrente e frequentemente observado em Curse of the Starving Class assim como em outras peças familiares é o destino, a noção de que seja lá qual for a sua maldição, ela é tão inescapável quanto a morte. $\mathrm{O}$ falar sobre maldições, tanto femininas quanto familiares, e imagens de sangue e doença permeiam esta peça. Fala-se muito sobre linhas familiares e qualidades hereditárias. Até mesmo Ella, que reivindica que a autodestruição não corre no sangue da família dela, fala sobre a 'maldição': "Refere-se a tempos passados a células bem pequeninhas e genes... Nós herdamos isso tudo e passamos adiante para novas gerações, e então eles a transmitem novamente" (p. 174). 
No último ato, Emma e Wesley discutem as transformações dele:

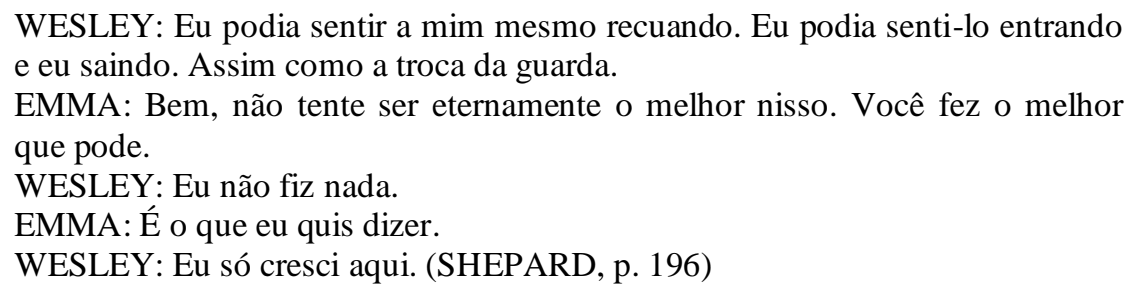

Esta passagem implica que o ambiente onde Wesley cresceu também teve participação no seu destino. A questão sobre se o alcoolismo é transmitido geneticamente ou ambientalmente fica em aberto na peça. $O$ que é universalmente reconhecido, entretanto, é que "alcoolismo flui nas famílias" (DEUTSCH, 1982, p. 75). Sem tratamento, o alcoolismo perpetua-se através das gerações, e é considerado uma das maldições da classe faminta.

\subsubsection{Sam Shepard e o outro drama americano}

A peça de Sam Shepard Curse of the Starving Class é um bom exemplo das possibilidades de significado que o título sugere. Primeiramente o título nos impressiona pela presença de palavras como "curse" e "starving" as quais transmitem um forte significado. Não é coincidência que a peça se parece com o título pela direta correspondência que ele tem com o tema: a hereditariedade vista como "curse" e "starvation" como uma completa falta de amor.

A ideia de hereditariedade é explorada na maneira como os pais passam sua falta de amor e carinho para seus filhos na peça, como uma espécie de herança que eles serão incapazes de evitar. Ao ler as primeiras páginas, o leitor é introduzido a essa falta de comprometimento que os pais apresentam em relação às crianças, enfatizando a ideia de que essa herança representa uma maldição nas vidas dos filhos. A transferência dessa falta de amor da geração dos pais para geração dos filhos é um padrão que não oferece saída, mas uma constante repetição da mesma coisa. A mesma falta de comprometimento que os pais têm em relação aos filhos será igual às atitudes que os filhos terão mais cedo ou mais tarde.

A família é formada pela mãe, filho, filha e pai, sendo que a casa onde eles moram está em ruínas em algum lugar do Oeste americano, porém durante a leitura da peça não descobrimos exatamente onde a casa está localizada. Desde o início da peça não temos a impressão de ser um lugar aconchegante, uma vez que a primeira imagem que temos é de um garoto que metodicamente recolhe os pedaços da porta da cozinha e os coloca num carrinho de mão. A porta havia sido quebrada e começamos a imaginar o que haveria acontecido. Quando a mãe começa a conversar com o filho na primeira cena, ficamos sabendo o que havia acontecido na noite anterior: o pai que estava bêbado havia quebrado a porta porque a mãe a havia trancado de propósito, para não permitir que ele entrasse em casa, supostamente porque ele bebe muito.

A família e a casa estão num verdadeiro caos, desintegrando-se É importante relacionar esta crise com o momento histórico, a decadência das pequenas propriedades rurais americanas, a crise dos valores tradicionais contrastada à pujança das grandes cidades e o papel de ponta americano na modernidade global; na peça, moderno e arcaico se 
encontram o tempo todo - a geladeira, corpo estranho da técnica naquele mundo de tradição, e a crueza do cordeiro comido sanguinolentamente, renovação do papel de caçador coletor, mergulho no mundo natural e instintivo. Esta diferença - o mundo da natureza e o mundo da história, da cultura - está presente na peça de Shepard. A crise é de um modelo de família, porém profundamente datada e historicizada, americana. O insight de Shepard está em mostrar como o tempo todo esta origem cultural da peça aparece para os personagens como um dado de natureza, inescapável, como a hereditariedade. Isto se evidencia na própria forma da peça, no hiper-realismo dos cenários, na escolha dos nomes dos personagens (Emma/Ella, quase o mesmo nome). Os personagens jovens se sentem condenados a ocupar os mesmos papéis sociais dos pais, não vêem saídas, apesar de promissores (Ella é boa aluna, por exemplo). A menstruação, outro exemplo, aparece como uma encarnação desta barreira históricosocial (a falência da pequena propriedade americana nos novos tempos e a caducidade dos valores familiares tradicionais) convertida em destino incontornável, força da natureza daí a tragédia. A porta quebrada é a nossa primeira pista da atmosfera que vai prevalecer durante toda a peça, física e espiritualmente. Fisicamente no sentido que os pedaços da porta quebrada transmitem sobre a desintegração e espiritualmente no sentido que o garoto recolhe os pedaços da porta metodicamente, como se ele fosse uma vítima não afetada por aquela violência.

A filha é uma aluna com excelentes notas e que está enfrentando a sua primeira menstruação. Ironicamente referem-se a sua primeira menstruação como "curse". A alusão é feita pela mãe na primeira cena, e parece que ela quer enfatizar que a menstruação é uma verdadeira maldição na vida de uma mulher:

Agora eu sei que a primeira coisa que você vai pensar é que você se machucou. Isso é natural. Você vai achar que algo drástico deu errado no seu interior e é por isso que você está sangrando ... (p. 138)

Mais tarde na peça, Emma, a filha, revelará o seu lado violento, quando ela pega um cavalo selvagem dizendo que vai deixar a casa, "I' $m$ leaving this house". Ela também sonha em trabalhar como mecânica no México, enganando a mãe deles da mesma maneira que ela imagina que a mãe a enganou.

Ella está negociando com um advogado, que provavelmente é desonesto, para vender a casa onde eles moram sem que o marido saiba sobre a negociação, pois ela pretende partir para Europa com os filhos. Enquanto a mãe faz de tudo para escapar do lugar e obviamente do marido, o filho, Wesley, parece obcecado com a ideia de ficar e cuidar do local. A mãe quer dividir a família e ir embora, ao passo que Wesley pensa que a família tem que ficar unida.

O pai parece estar com problemas porque ele está devendo dinheiro a uma gangue de homens desonestos e está, assim como a mãe, nas mãos de pessoas traiçoeiras. Pessoas que querem tirar tudo dele. Essas pessoas são credores que farão tudo que puderem para lucrar com o caos financeiro e emocional da família. Essas pessoas explodem o carro da família com Emma dentro dele e parecem determinadas a não pararem até que peguem o pai, que foge para não pagar seus débitos e enfrentar a situação que ele mesmo criou.

A primeira imagem importante na peça, a do garoto que recolhe os pedaços da porta de maneira indiferente e calmamente, transmite a ideia de que a violência é aceita e tomada como uma ocorrência normal na casa daquelas pessoas. Quando a mãe entra em cena, 
percebemos a indiferença que os membros dessa família têm uns pelos outros. Nada a afeta e nossa lógica é perturbada quando o irmão urina no cartaz da irmã, mas a mãe não faz nada para pará-lo ou impedi-lo.

Imediatamente nos perguntamos que tipo de família é essa. Uma família, cujo pai quebra a porta para poder entrar, além de estar bêbado e completamente fora de si com uma mãe que parece não dar importância para os filhos, e um filho que urina no trabalho da irmã. Caos pode ser visto e sentido em todos os lugares que você olhar: emocional, como se houvesse uma completa impossibilidade de manter uma relação familiar aceitável; financeira, como na impossibilidade de manter a casa, reabastecer a geladeira, dever dinheiro que você não tem para poder pagar suas dívidas. Desde o começo, a família nos é mostrada como uma união paradoxal: onde a vida é concedida e também destruída.

Na peça, os pais são incapazes de dar aos filhos amor e abrigo e ao longo da peça eles se tornam figuras ameaçadoras, pois é difícil para eles serem pais protetores. A mãe é indiferente e pelo fato de o pai beber pode ter destruído todo o comprometimento em relação à família.

As maldições na peça se referem ao que é transmitido de uma geração para outra, como quando a filha assume o papel da mãe e a transformação do garoto no pai.

A primeira referência à primeira menstruação da garota está (SHEPARD, 1981, p. 138) quando a mãe inicia um monólogo tentando esclarecer o assunto. Ela quer que a filha saiba os fatos reais (apesar de ela estar falando com ela mesma) e não que ela aprenda um monte de mentiras como ela diz. Ela enfatiza que a garota nunca deveria ir nadar, pois isso poderia fazê-la sangrar até a morte. Nesse momento a garota entra em cena e ambas começam a conversar como se estivessem continuando a conversa anterior que a mãe tinha com ela mesma. A garota quer ir nadar na piscina aquecida dos vizinhos, mas a mãe diz que não. Ela diz que não é piada e que a vida da filha está mudando. Então ela começa a explicar para ela sobre absorventes higiênicos, porque ela não gostaria que a garota os usasse. Ela não acredita que eles sejam seguros uma vez que eles podem misturar-se com as moedas inseridas nas máquinas para comprá-los. Para ela essas coisas carregam germes.

Ella está determinada a mostrar fatos reais sobre menstruação para Emma, mas ela não consegue nem explicar o que um ciclo menstrual é na realidade. A sua antiga visão sobre o assunto é carregada de preconceito. Instantaneamente entendemos que o período menstrual é algum tipo de doença. É sujo. É um invasor. A ideia de sujeira é contrastada com os absorventes higiênicos sem germes, tão limpos como um hospital. Emma não pensa que o período menstrual é uma função biológica natural a qual exige cuidado elementar. A obsessão da mãe com as funções biológicas da mulher vai além:

Você sabe o que é isso? É uma maldição, eu posso senti-la. É invisível, mas ela está lá. Todo dia eu posso sentir isso. Todos os dias eu possa vê-la chegando. E ela sempre vem. Se repete. Ela vem mesmo quando você faz tudo para impedi-la de vir. Mesmo quando você tenta mudá-la. E ela vai voltar. Profundamente. Ela vai voltar e voltar para pequenas células e genes. Para átomos. Para pequenas coisas nadando e compondo suas mentes sem nós. Conspirando no útero. Antes disso mesmo. No ar. Estamos cercados dela ... Ela vai mais longe também. Nós a espalhamos. Nós a transmitimos. A 
herdamos e passamos para frente, e depois a passamos novamente. Ela vai continuar mesmo sem nós. (SHEPARD, 1981, p.173)

Ella parece se ressentir da sua condição de mulher e de ter a 'maldição' como ela chama a sua condição biológica, e conseqüentemente sua condição de mulher e mãe. Sabemos que o ciclo menstrual é uma referencia à capacidade de uma mulher gerar filhos; é o que determina quando ela está apta a ficar grávida. É provável que Ella esteja culpando sua condição de mulher e mãe. A calma aceitação desses fatos por parte de Emma mostra que a 'maldição' da mãe está começando a ser passada de mãe para filha. A "maldição" do título refere-se à inevitabilidade da repetição, geração após geração, dos mesmos pontos de vista e atitudes sem significado que os pais têm.

A menstruação como um símbolo de fertilidade é visto como um desastre feminino pela mãe. A 'maldição' que a mãe passa para filha tem outras implicações. Emma se ressente do fato de a mãe sair com o advogado para o qual ela está vendendo a casa. Ela sabe que eles passaram a noite juntos. Apesar de ela fazer um esforço para reconhecer que a mãe precisa de um pouco de carinho, ela acredita que a mãe comporta-se como uma prostituta para conseguir o que ela quer. Quando Ella volta para casa ela traz a promessa de vender a casa para o advogado, e ironicamente ela traz muita comida para por no refrigerador, o que sugere que ela foi paga por sair com seu amigo advogado.

Mais tarde na peça, Emma irá repetir o mesmo padrão de conduta: ela ouve a conversa do pai com o irmão sobre vender a casa para o dono do Alibi Club. Emma perde a cabeça, pega o cavalo e um rifle e vai até o Álibi Club. Dá vários tiros no lugar e então é presa. Nesse momento percebemos que o veneno da mãe é transmitido para Emma. Na página 196 ela explica para o irmão como escapou da prisão; ela conta para ele que fez propostas sexuais para o sargento. Emma assume a conduta da mãe para conseguir o que ela quer:

\author{
WESLEY: O que você fez? \\ EMMA: Eu saí. \\ WESLEY: Eu sei, mas como? \\ EMMA: Eu fiz propostas sexuais para o sargento. Foi assim. \\ Fácil.
}

Então Emma conta ao irmão que ela vai começar a cometer crimes uma vez que isso é a única coisa que dá dinheiro hoje em dia. Percebemos que ela está completamente infectada pela atitude da mãe e não há saída para Emma. Seu potencial inicial para o raciocínio foi-se. Suas excelentes notas não a ajudarão mais. Ela foi corrompida pela falta de valores reais da mãe. Ela acredita que não tem nada para perder. Ela não tem outra motivação além de seguir os passos da mãe, pois essa é sua parcela na herança de seus pais. Ela ironicamente rouba o dinheiro da mãe, o qual ela recebeu do advogado, pega o carro da família e foge.

Existe um padrão que arruína a família inteira: é a passagem da "maldição" de geração para geração com a óbvia repetição do mesmo ato sem significado por parte dos filhos.

A família retratada por Shepard em Curse of the Starving Class é aquela que fracassa por completo ao cuidar de seus filhos. É uma família guiada pelo princípio masculino o qual é violento para o homem do meio-oeste americano, por exemplo. A figura feminina a qual traria o princípio feminino não pode proteger seus filhos da violência 
masculina. Toda violência vinda dos homens na peça não pôde ser evitada pelo princípio feminino.

Emma representa um dos poucos personagens femininos nas peças de Shepard que carrega consigo um pouco da violência masculina. Sua natureza colérica leva-a a ter atitudes as quais poderiam ser mais esperadas de personagens masculinos, tais como: cavalgar um cavalo selvagem ou atirar no Alibi Club. Concluímos que ela está totalmente afetada pela indiferença da mãe porque ela não se importa mais com o que lhe aconteça; a conduta dela carrega muito da insanidade dos homens na peça. Os homens na peça derrotam qualquer tentativa das mulheres de proporcionar à família um ambiente mais saudável. Ella também possui a violência e a mesquinhez dos homens na peça, possivelmente como uma maneira de sobreviver. $\mathrm{O}$ futuro de Emma não poderia ter sido pior. No final ela torna-se uma vítima dos credores que estão procurando o pai dela, o que sugere que o princípio feminino é uma vez mais destruído pela violência masculina.

A maldição do título refere-se também ao fato de o filho estar contaminado pelo veneno do pai. A primeira referência a Wesley ter assumido a conduta de seu pai pode ser vista na página 167 quando Weston menciona como ele foi infectado com o veneno do seu próprio pai. No princípio, Wesley não parece ser capaz de entender seu pai. Ele muda de assunto ao oferecer ao pai alcachofras, provavelmente como uma reação de medo.

Weston está tentando avisar seu filho sobre o seu próprio veneno: o padrão de conduta que tende a ser constantemente repetido na família. Logo após conversar com o pai ele dirige-se ao cordeiro que ele está cuidando na cozinha: "Coma a ovelha americana. Vinte milhões de coiotes não podem estar errados." (p. 191)

Como uma espécie de ritual das pessoas famintas na família, Wesley bate a porta do refrigerador e diz para o cordeiro que ele não vai matá-lo, não o fará porque ele não considera a ele mesmo como um membro da classe faminta. Apesar de ele recusar qualquer tipo de identificação com a classe faminta do título, esse ritual e conversa com o cordeiro são as nossas primeiras pistas de que ele estará pronto a por em prática as mesmas atitudes do pai. A constante repetição desse ritual mostra que Wesley, mais que qualquer um em sua família, está faminto não só de comida, mas basicamente de amor. Ele não consegue encontrar um modelo de homem para converter a imagem do pai.

Durante o curso da peça, a transformação de Wesley em seu próprio pai acontecerá da mesma maneira que a de sua irmã. É através de um conjunto de atitudes que Wesley e Emma desenvolvem durante a peça que a expressão de falta de amor e o sentimento de abandono manifestam-se neles assim como a constante caça à comida no refrigerador.

No Ato III, Wesley será dominado por uma força irracional que o fará procurar desesperadamente por uma identificação com seu pai. Ele veste o boné sujo de seu pai, o casaco e o par de tênis, tenta o banho frio e quente sugerido pelo pai, e perambula completamente despido pela casa além de tentar o renascimento do pai o quanto ele pode, mas não funciona. Agora ele está pronto para representar a "maldição" de seu pai: ele mata o cordeiro e o come cru. Assim, curiosamente, enquanto o pai estava transformando-se num novo homem, restabelecendo seu senso de comunhão com a terra, percebendo o elo físico que mantêm a família unida, o filho estava herdando a 'maldição'. 
Quando Wesley entra na cozinha e cumprimenta seu pai, Weston fica horrorizado ao vêlo em suas roupas. Wesley anuncia que matou o cordeiro e repete o ritual de ir ao refrigerador. Dessa vez loucamente, retirando todos os tipos de comida e comendo vorazmente. Nesse momento, a transformação do pai em um novo homem, a qual traria alguma esperança para o caos familiar, é absolutamente eliminada. Wesley faz sua entrada na 'classe faminta'. Ele finalmente assume que ele é o homem faminto da sua família, ou que ele está mais faminto do que qualquer outro personagem, mais do que nunca.

Em American Playwrights: A Critical Survey, 1981 Bonnie Marranca salienta a maneira interessante que Shepard usa, durante toda a peça, o ato de comer como uma maneira de evitar a emoção, uma reação para ansiedade do medo, uma resposta a eventos externos dramáticos. Na peça, todos sempre batem a porta do refrigerador. Durante a peça, essa é uma atitude repetida pelos membros da família várias vezes. Wesley é o que mais repete o gesto. A falta de amor é transmitida pela imagem da fome.

Shepard mostra o conflito entre gerações de pais e filhos, causado pela herança que os filhos recebem dos pais num padrão de repetição da conduta dos pais, o qual os filhos parecem muito fracos para evitar, e portanto, repetem as atitudes dos mesmos durante toda peça com poucas possibilidades de encontrar uma saída. Shepard parece querer mostrar o poder inexorável da herança, não somente física, mas psicológica, assim como a força da luta entre pai e filho com o domínio do segundo sobre o lugar do primeiro.

Em peças como The Son (HASENCLEVER, 1912) que foi uma das primeiras peças expressionistas cujo tema principal é o conflito entre gerações e a rejeição do mundo moderno pelos jovens e Patricide (BRONNEN, 1922) o conflito entre pai e filho é expresso num padrão onde o pai representa autoridade, disciplina e ordem enquanto os filhos representam paixão e idealismo. Os filhos nessas peças odiavam as figuras dos pais porque elas os impediam de viver a vida intensamente. Essas peças estão ligadas as de Shepard pela temática.

Uma geração inteira de escritores expressionistas sonhou em matar seus pais para levar a vida naturalmente e assumir o papel dos mesmos também. Com tendência para o extremo e o exagero, as peças expressionistas são combativas na defesa de transformações sociais. O enredo é muitas vezes metafórico, com tramas bem construídas e lógicas. Em cena há atmosfera de sonho e pesadelo e os atores se movimentam como robôs. Muitas vezes gravações de monólogos são ouvidas paralelamente à encenação para mostrar a realidade interna de um personagem.

A primeira peça expressionista é A Estrada de Damasco (1898-1904), do sueco August Strindberg (1849-1912). Entre os principais dramaturgos estão ainda os alemães Georg Kaiser (1878-1945) e Carl Sternheim (1878-1942) e o norte-americano Eugene O'Neill (1888-1953).

Ao Expressionismo se deve à renascença do teatro nos EUA. Durante o século XIX só houve (como na Inglaterra vitoriana) peças poéticas para a leitura; os palcos estavam, ainda no começo deste século, dominados por homens como Belasco e outros autores de dramalhões populares. A salvação veio dos amadores, que se transformaram, aliás, com o sucesso, em atores profissionais. Assim os Provincetown Players, em cujo primeiro 
caderno programático O'Neill declarou sua dívida para com Strindberg e Wedekind. Foi o primeiro grande dramaturgo norte-americano, o maior e - conforme a opinião de muitos críticos - já quase o último, pois seus sucessores não lhe alcançaram a estatura nem sequer a fecundidade. Clifford Odets (n.1906) só obtinha sucesso enquanto cultivava, no palco, a propaganda política.

Maxwell Anderson (n.1888) e Elmer Rice (n.1892) não cumpriram a promessa das primeiras obras. Arthur Miller era um intelectual, em oposição à 'mass culture' e suas consequências políticas e sociais. Tennessee Willians pertence ao movimento literário do sul dos EUA, com fortes interesses psicológicos e psicopatológicos. Os teatros da Broadway voltaram a ser dominados pela produção comercial, às vezes com verniz literário (S. Behrman, Lillian Hellman, George S. Kaufman). Só Thornton Wilder manteve o alto padrão literário do seu estilo expressionista. Entre as muitas ramificações do teatro expressionista ainda merece menção um original autor em língua iídiche, S. Anski (1863-1920), cujo drama místico O Dibuk foi representado em muitas línguas.

Essas obras contrastam com Curse of the Starving Class, onde o conflito de gerações é mostrado de uma maneira diferente. Constatamos razões óbvias para acreditar que Wesley odeia seu pai, mas talvez ele não tenha consciência desse fato. O que ele realmente sente falta na figura do pai é a possibilidade de se identificar com ele uma vez que o papel dele como pai foi absolutamente revertido. Weston parece não ser capaz de prover Wesley com segurança, proteção, estabilidade e, acima de tudo, amor. Weston transformou a figura de guia esperada de um pai em uma ameaça.

Como Weston fracassa em resolver a crise econômica pela qual a sua família está passando, ele perde os próprios princípios que o guiavam. Ele se torna irracional e age como um homem sem valores morais para se apoiar, tornando-se um jogador para não enfrentar o que o cerca, como uma maneira de escapar e sonhando em vender sua casa para pagar seus débitos. Ele sonha em ir para o deserto com sua promessa de liberdade; o que ele que efetivamente faz no final, talvez para escapar dos laços familiares e da civilização.

O padrão de disciplina e autoridade é substituído pelo padrão do caos. Ao permitir que sua fazenda deteriore-se, Weston carrega toda sua família com ele. $\mathrm{O}$ fato de ele beber torna a situação ainda pior e também enfatiza o fato de ele não poder resolver a crise financeira que está arruinando a família. Ele não consegue dar ao filho o modelo de homem correto, pois lhe falta base moral e psicológica que geralmente forma os homens comuns.

A identificação entre pai e filho tendo como base o amor nunca ocorre porque não é possível para Weston demonstrar sua preocupação com os filhos. O modelo de homen que ele oferece para Wesley é cheio de ódio e violência e veneno como ele mesmo reconhece. No final, Wesley não consegue deixar de assumir a atitude do seu pai. Quando Weston tem que partir porque os credores estão atrás dele, Wesley definitivamente toma o lugar de seu pai na casa.

No final do Ato III, nem sua própria mãe consegue diferenciar Wesley de Weston. A imagem final em Curse of the Starving Class mostra mãe e filho, contando um para o outro a história da águia, uma história que Weston costumava contar. Ele se identifica 
com a águia, pois ela o faz lembrar de quando ele voava um bombardeiro B-49. A história é contada num longo monólogo na página 183 . Weston é interrompido por Wesley e recusa-se a terminar a história e só sabemos do final quando mãe e filho recontam a história na página 200. Eles alternam as falas dizendo que um gato vai para o telhado para cheirar as entranhas então a águia vem e leva o gato em suas garras. $\mathrm{O}$ gato rasga o peito da águia, a qual quer soltá-lo e finalmente ambos caem e morrem. Essa imagem conclui a peça.

Essa imagem final em Curse of the Starving Class representa o vínculo da família, a mulher e os filhos dependentes do pai, o qual se afasta das responsabilidades e leva a família à destruição. Os membros da família, assim como o gato, agarram-se a ele em desespero, e isso acaba por destruí-lo. No final todos acabam caindo, eles estão atados uns aos outros por um elo biológico, seus destinos estão determinados pela sua interdependência num vínculo que não pode ser quebrado.

Ao contar a história da águia, Shepard fecha a sequência de imagens de destruição na peça, enfatizando que os laços familiares foram completamente destruídos. A imagem da águia é um tradicional arquétipo da figura do pai. Além de refletir a decadência da família, também se caracteriza como um poderoso lembrete da decadência da sociedade moderna americana. A decadência é de certo modelo de sociedade tradicional e rural. Os valores americanos urbanos, estes caminham em alta. Não se trata de fazer um julgamento moral se este apogeu do American way of living no pós-guerra é funesto, mas constatar que seu sucesso coloca sem rumo toda uma parcela da sociedade americana e que seu brilho tem como contraparte fome e sofrimento que não ganham as vitrines da propaganda nacional. Talvez não se trate de um lembrete da "decadência da sociedade moderna americana", mas dos custos sociais e humanos da sua imposição como modelo vencedor em escala global.

Os personagens em Curse of the Starving Class nos dizem muito sobre eles mesmos, ao invés de termos outros personagens ou mesmo o escritor nos contando sobre eles, a existência dos personagens tem o seu próprio valor, o que significa que eles existem anteriormente à ação, não por causa dela. De certa maneira os personagens em Curse of the Starving Class não são somente atores interpretando suas partes na peça, mas personagens sendo executores no sentido de improvisar para os expectadores aspectos particulares e imaginativos de suas vidas. Essas pessoas são incapazes de ver além de seus estados mentais, o que pode significar que eles estão presos em seus sonhos e imaginação sem possibilidade de ver o mundo do lado de fora.

Os personagens de Shepard são capazes de representar fragmentos, vazios e transformações. As emoções do personagem passam a ser projeções do seu imaginário pessoal, começando com uma simples percepção até uma construção de uma sequência de imagens as quais podem ser verbais, visuais ou auditivas. Esse conjunto de imagens contém aquela percepção inicial a qual está além da imediata situação do personagem, numa área da sua imaginação.

A realidade com a qual Shepard lida em Curse of the Starving Class desconsidera a expectativa do racional, o que significa que a realidade que ele descreve na peça não é objetiva, não deve ser encarada racionalmente. A realidade que ele apresenta em Curse of the Starving Class é uma que leva em conta os atos internos das mentes de seus personagens. O que assistimos é uma configuração externa dos atos internos dos 
personagens ou dos processos internos de suas mentes. As diferentes vozes que os eles assumem durante o curso da peça são tentativas de refletir a profundeza emocional das suas mentes subconscientes. Mas as circunstâncias que determinam estas cicatrizes emocionais são bem fundadas em processos históricos contemporâneos aos fatos. A forma não é mais a do drama realista, do drama burguês - ainda que essa forma seja forjada em diálogo como o realismo americano nos palcos - a história contemporânea está em xeque na peça, é a matéria com a qual ela se bate.

O American way, também conhecido como American way of life, é uma expressão referente a um suposto 'estilo de vida' praticado pelos habitantes dos Estados Unidos da América. É um exemplo de uma modalidade comportamental desenvolvida no século 17 e praticada até hoje. Refere-se a um ethos nacionalista que se propõe aderir aos princípios de vida, a liberdade e a procura da felicidade (direitos não-alienáveis de todos americanos de acordo com a Declaração de Independência). Pode-se relacionar o American way com o American dream.

Durante a Guerra Fria a expressão era muito utilizada pela mídia para mostrar as diferenças da qualidade de vida entre as populações dos blocos capitalista e socialista. Naquela época, a indústria cultural americana abraçava a ideia de que qualquer indivíduo, independente das circunstâncias de sua vida no passado, poderia aumentar significativamente a qualidade de sua vida no futuro através de determinação, trabalho duro e habilidade. Politicamente, o American way acredita na 'superioridade' da democracia dita livre, fundada num mercado de trabalho competitivo sem limites.

Analisando a história da formação dos Estados Unidos, encontramos as Treze Colônias que eram divididas em Colônias do Sul e Colônias do Norte. Porém, essas colônias tiveram um modelo de colonização diferenciado entre si. O Sul apresentou características típicas da colonização de exploração, onde as terras foram divididas em grandes latifúndios, baseados na monocultura do algodão e do tabaco, com uso intensivo de mão de obra de africanos escravizados, a produção voltada para o mercado externo. Já o Norte apresentou uma colonização diferenciada, ou seja, uma colonização de povoamento, com o predomínio de pequenas e médias propriedades, o trabalho livre e assalariado, a produção voltada para atender ao mercado interno, o incentivo a instalação de indústrias, dentre outros.

A diferença entre o Norte industrializado e o Sul agrícola, levou os EUA a uma guerra civil, entre 1861 a 1865, conhecida como a Guerra de Secessão, na qual o Norte saiu vencedor, provocando a libertação dos escravos no país. A partir daí, o país começou a ter seu parque industrial difundido pelo seu território.

Os Estados Unidos começaram a ser uma potência mundial a partir da Primeira Guerra Mundial, quando a Europa, que na época era a maior potência econômica, ficou arrasada após a guerra, servindo para que os Estados Unidos fosse o grande fornecedor de produtos para o continente europeu. A Segunda Guerra Mundial fortaleceu esse domínio. Durante o período de 1945 a 1991, o país disputou acirradamente com a União Soviética o poder hegemônico mundial, no período denominado de Guerra Fria. A Guerra Fria serviu para os EUA aumentar seu poderio mundial, e hoje o país é a maior potencia econômica mundial. 
Com o fim da União Soviética e a criação de 15 novos países, os EUA passaram a ter uma hegemonia do poder e economia mundias. Isso fez com que o país se autoproclamasse o único com o direito de mandar e desmandar nas questões relacionadas à economia e a geopolítica.

Com base nisso foi criada em 20 de setembro de 2002, pelo então presidente George W. Bush, a Doutrina Bush, pela qual o país tinha o direito de tratar como terroristas os países que abrigam ou dão apoio aos grupos terroristas. Isso foi uma justificativa utilizada para a invasão no Iraque e no Afeganistão. Essa doutrina promoveu o desgaste da imagem dos Estados Unidos perante o mundo. Preocupado com as questões internacionais e menos com as questões internas, o país começou a mergulhar em uma crise sem precedentes.

A doutrina Bush mudou a direção das relações internacionais dos Estados Unidos, substituindo os princípios da contenção da época da Guerra Fria - baseada na persuasão e dissuasão - pelos ataques preventivos. Consolidou o unilateralismo como princípio norteador da nova política externa norte-americana, indiferente aos tratados e instituições internacionais.

Nos dias atuais, a expressão novamente se tornou presente, graças à crença espalhada tanto por Bush pai quanto por Bush filho de que o estilo de vida americano não pode ser ameaçado nem negociado. Bush pai utilizou o American way em 1992 para recusar propostas de diminuição das taxas de gás carbônico, dizendo que o American way "não pode ser negociável". Já Bush filho utilizou-se da expressão para convencer a população americana a apoiá-lo na "instauração da democracia" no Afeganistão e no Iraque, dizendo que o American way não pode ser ameaçado por outras nações

O monólogo falado por Wesley na página 137 mostra como a ideia de trabalhar com os processos internos dos personagens pode ser verbalizada: "Eu estava lá deitado de costa [...]. Decalques descascando das asas [...]"

O monólogo de Wesley concentra-se em produzir imagens, na sua maioria visuais, como o cheiro dos abacates florescendo, ouvir os coiotes, sentir a presença de pessoas do lado de fora, sentir os animais do lado de fora e outras mais. Wesley mostra uma percepção precisa do que o cerca, mas também o seu próprio isolamento. O diálogo (Curse of the Sarving Class, p. 141 e 142) apresenta um exemplo interessante dos sentimentos que experimentamos através dessas explosões. Emma está tendo uma discussão com sua mãe porque ela usou a galinha que ela estava guardando para sua demonstração na escola.

$\mathrm{Na}$ realidade, esse evento na peça subverte nossas expectativas, ninguém esperaria que um irmão urinasse no trabalho da irmã e ninguém esperaria que a mãe ficasse totalmente indiferente como se aquilo fosse um ato normal. Nessa parte da peça Emma é a única que ainda consegue raciocinar. Na página 142 Emma pergunta: "What kind of family is this?".

Quando Emma finalmente diz que está partindo, a mãe e o irmão não parecem importarse. Apesar de a mãe chorar e dizer que ela é muito jovem para partir, ela não faz nada para impedi-la. Imediatamente a mãe passa a contar ao filho sobre a venda da casa. Não existe nenhum tipo de preparação para nos expor a essa mudança. De uma situação extrema, os personagens movem-se novamente. Somos expostos a situações extremas e 
as mudanças ocorrem sem que estejamos preparados para elas. Os movimentos dos personagens fazem nos lembrar de fantoches. Eles parecem ser controlados por forças exteriores que nunca cessam como vítimas de um mundo que perdeu seu centro. $\mathrm{O}$ destino histórico vira biológico escravizando suas vítimas.

O atuar dos personagens também está de acordo com a ideia de comportarem-se como fantoches, pois usam um conjunto de gestos expressivos que geralmente levam a um exagero. Um dos melhores exemplos disto é quando Wesley urina no trabalho de Emma, ou quando ele não consegue renascer como seu pai e mata o cordeiro e come-o vorazmente. (SHEPARD, 1981, p. 191).

Os personagens nessa peça de Shepard representam ideias abstratas como arquétipos fazem. Eles movem-se pelo mundo expressando suas condições anônimas, sempre fazendo um grande esforço para encontrar significado em seu mundo. Apesar disso a busca deles é sempre frustrada. Eles não são heróis e sua integração no mundo nunca acontece na verdade; eles são anti-heróis. A abordagem psicológica traria uma ordem causal ao empenho deles. Suas histórias não são bem desenvolvidas; são fragmentos de uma existência. Esses dois elementos (falta de características psicológicas mais antecedentes, o que seria a história de um indivíduo) enfatizam a condição deles de seres anônimos, fantoches.

A escolha de nomes por Shepard é também um mecanismo interessante na peça. Ella/Emma, Weston/Wesley são nomes praticamente permutáveis. Logo, os personagens começam a mostrar que não há distinção entre eles. Em peças expressionistas a falta de nomes expressava uma crescente tendência do movimento para a despersonalização. Em Curse of the Starving Class, a mesma tendência é observada nessa escolha de nomes curtos e permutáveis, mas ao mesmo tempo Shepard poderia estar tentando antecipar que mais cedo ou mais tarde iriam transformar-se nos pais. Eles assumiriam seus papéis, particularmente ao herdar suas atitudes deterioradas. De qualquer maneira a escolha de nomes de Shepard enfatiza a falta de identidade dos personagens, para ele o nome é mais uma asserção do que um identificador.

Parece haver muita distorção nos papéis que homens e mulheres interpretam na peça. Emma, Ella, Weston e Wesley acreditam que estão interpretando mulheres e homens, mas o que eles realmente estão interpretando é como eles imaginam que mulheres e homens se comportam. Falk (1977) enfatiza que a representação dos personagens é tirada da comunicação de massa, sendo exagerada, simplificada e codificada. Para ela, "comerciais transmitem representações idealizadas de homens e mulheres como imagens da moda."

Homens e mulheres em Curse of the Starving Class não são descritos em termos de igualdade. Bonnie Marranca diz que "os personagens femininos em Shepard ficam ao fundo do palco nas peças". "Elas perambulam e sempre estão a postos para certas tarefas caseiras enquanto os homens tomam as decisões, correm riscos, enfrentam desafios, passam por crises existenciais. As mulheres são maltratadas e sempre tratadas como subservientes aos homens, o potencial delas para crescimento e desafios é restrito".

Emma é a única personagem feminina na peça que é capaz de ser assertiva. Ela reconhece que deve haver algo extremamente estranho com sua família e aproveitamos bons momentos de seus raciocínios. Ela se torna violenta e aprende rapidamente a lição 
com sua mãe. Algumas das características masculinas que ela apresenta, como ser sonhadora, a distinguem de outros personagens femininos em Shepard. Entretanto, a figura masculina em Curse of the Starving Class não é só um sonhador, mas também aquele que experimenta visões. Shepard concentra-se na experiência masculina como o centro de energia em suas peças. Os personagens masculinos falam mais linhas e tendem a dominar a ação. Suas histórias fragmentadas são as histórias de homens que não se encaixam no meio ambiente onde vivem.

Na peça, a ingestão das entranhas representa a força masculina e consequente domínio. Esta é a razão pela qual Weston ganha tamanha força ao contar a história. (página 183) Na página 186, Weston reconhece que a família é fundada em carne e sangue, "[...] family wasn't just a social thing. It was an animal[...]", apesar disso ele se recusa a tomar conta dos filhos e parece ver seu papel de pai como um exercício fálico. Weston escapa dos laços familiares quando vai para o deserto na sua busca individual de si mesmo.

Homem e mulher na peça não são capazes de levar adiante nenhum tipo de relacionamento. Eles não experimentam nenhum tipo de contato humano e não conseguem expressar seus sentimentos uns para os outros. Eles agem como vítimas de um mundo onde o destino impera e do qual não há escapatória.

Ellen Oumano, no seu livro Sam Shepard: the Life and Work of an American Dreamer, 1986, salienta que Curse of the Starving Class foi baseada em memórias e personagens da própria família de Shepard. Nessa peça, ele começou a lidar com temas familiares de hereditariedade e a crescente fragmentação e alienação da família americana. Nessa peça, sua linguagem foi considerada mais trabalhada e seus personagens mais profundos. A família sobre a qual ele fala incorpora as características de toda uma cultura, o mundo contemporâneo americano.

Os personagens na peça tornam-se tão estranhos como o mundo que habitam. A informação salienta Shepard, é dada a ele como uma sensação viva. Então, do seu ponto de vista, ele está mergulhando de volta na experiência atual de ter estado lá e escrever sobre isso como se estivesse acontecendo agora. Aprendemos pouco sobre seus nomes, e sobre seu passado íntimo, mas temos a chance de participar intensamente das suas experiências extremas, as quais são suas experiências presentes. Não podemos escapar de vivenciar seu desespero. Os elementos da realidade cotidiana são reunidos de acordo com as próprias obsessões de Shepard, esses fragmentos são unidos por um processo associativo da mente: de Shepard e a nossa própria.

Shepard define seu processo de criação como vindo de um processo no qual a experiência é constantemente armazenada em algum lugar na nossa mente, algo sobre o qual às vezes não temos nem consciência. No processo de criação, Shepard acredita no poder das palavras, não tanto na delineação das circunstâncias sociais do personagem, mas na sua capacidade de evocar visões ao olhar dos expectadores: "Words as living incantations and not as symbols."

Apesar de Shepard reconhecer que a estrutura de qualquer forma de arte nos leva a um tipo de limitação, e trabalhar com certos limites de língua, de acordo com Shepard "parece ser o único ingrediente nesse plano que retêm o potencial de dar saltos para o desconhecido". Um dramaturgo pode sempre fazer muito sobre aparências, costumes, adicionar novos personagens, mudar a iluminação, trazer objetos, trocar o cenário, mas 
a língua, na opinião de Shepard, "está sempre pairando lá, pronta para mover-se mais rápido e mais eficientemente do que tudo mais posto junto."

\begin{abstract}
A linguagem pode explodir do mais minúsculo impulso. Se eu estiver dentro do personagem no momento, eu posso captar o que ele cheira, vê, sente e toca. Num repentino flash, ele abre seus olhos, e as palavras seguem. Nesses tipos de erupção as palavras não são pensadas, elas são sentidas. Elas cortam através do espaço e fazem perfeito sentido sem ter que hesitar no 'significado. (em MARRANCA, American Dreams: The Imagination of Sam Shepard, 1981).
\end{abstract}

Shepard faz uso da linguagem que reflete as profundezas emocionais da mente subconsciente. Algumas vezes essa língua vem em fragmentos, mas esses fragmentos são postos juntos por um processo associativo da mente apesar dele ser pouco transparente para as personagens e parecer desgovernado, porém para o leitor essa estrutura da peça se justifica. Eles refletem pedaços de experiência, os quais se sobrepõem algumas vezes, mas sua interação criam padrões de força sugestivos. Com o uso desse tipo de língua mais seus cenários simples ele quer provocar uma resposta subjetiva nos expectadores. Ele quer que os expectadores participem num mundo de mito contemporâneo. Na peça esses fragmentos de língua são melhores exemplificados pelos monólogos de Wesley nas páginas 137 e 138, e de Weston nas páginas 182 e 183.

\title{
3.1.4 A fragmentação da linguagem em Curse of the Starving Class
}

Apesar de Curse of the Starving Class começar de uma maneira lógica e tradicional (como por exemplo, "uma linguagem tradicional comparável à do drama realista americano da primeira metade do século $\mathrm{XX}^{\prime \prime}$ ), com mãe e filho conversando sobre os eventos da noite anterior (a briga do casal), em breve essa exposição lógica será quebrada pelo devaneio de Wesley (p. 137 e 138). Ele nos passa sua própria visão da briga familiar. A princípio, ele nos dá um resumo poético de seus sentimentos através de imagens como 'cheirar', 'ouvir', 'sentir'. Ele demonstra que está consciente de seus sentimentos. No monólogo de Wesley, quando o pai aproxima-se da cena, o tom muda radicalmente e sentenças incompletas são introduzidas num rítimo staccato (p. 138).

A divisão que ocorre nos monólogos de Shepard é uma mudança da voz narrativa para ativa, de objetividade para subjetividade. Algumas vezes essa divisão/fragmentação ocorre com uma clara mudança de tempo verbal - do passado para o presente; outras vezes a divisão é causada pela ação da força narrativa pelo poder absoluto da linguagem. Podemos obsevar tudo isso no seguinte monólogo em Curse of the Starving Class:

Eu estava lá deitado. Eu podia sentir o cheiro dos abacates florescendo. Eu podia ouvir os coiotes. [...] Então eu ouço a porta do Packard abrir. [...] A mamãe chorando. Então nenhum som. Então chorando. Então nenhum som. (p. 45).

Nesse monólogo, a ação muda de velocidade e sai da narrativa para ativa através de mudanças de tempos verbais. A ação se inicia com uma experiência passada e é trazida até o presente; Wesley está se lembrando como ele se sentiu na cama na noite anterior. Com a pergunta: "O que ele está fazendo?" o tempo verbal é mudado para o presente. Outro fato interessante sobre esse monólogo é que a descrição da violência se torna mais explícita, a estrutura da sentença se torna mais curta e depois ele usa frases e palavras. No início as sentenças são simples, mas afirmações bem longas: "Eu podia 
sentir a mim mesmo na minha cama no meu quarto nessa casa nessa cidade nesse estado nesse país". No meio da fala de Wesley conforme a ansiedade aumenta Shepard quebra a estrutura da sentença reduzindo as sentenças ao mínimo: "Papai chama mamãe", ou apresenta somente frases: "A voz do papai", ou palavras: "Pés". Bonnie Marranca comentou sobre esse monólogo, observando que a ação:

[...] inicia-se num humor pessoal vagarosa e alegremente [...] então passa-se a mover numa corrida rápida de sentenças incompletas. Imagens são definidas em frases curtas cujo ritmo staccato ecoa as batidas do coração de Wesley. (p. 47)

Em outro monólogo de Curse of the Starving Class, a ação presente invade um devaneio e a atriz é forçada a representar a invasão:

EMMA: Ela está contando para ele tudo sobre nós e como papai está louco tentando matá-la o tempo todo. [...] De manhã eu cobro duas vezes pelo trabalho; os vejo ir embora, e revendo o motor deles por uma boa quantia de dinheiro. (p. 48)

Um padrão de crescente intensidade é alcançado pelo uso do particípio nas sentenças que Wesley diz. Temos o sentimento de que tudo está acontecendo agora. A construção passiva chama-nos a atenção, primeiramente porque a sintaxe assinala uma história que está chegando ao final, como se ao contar a história o contador não estivesse mais lá na primeira pessoa como ele esteve durante o resto da história, e, segundo, porque o narrador é deslocado pelas coisas da paisagem que circundam a história.

A mudança radical é feita para contrastar o discurso lógico do começo da peça com a exposição não lógica que está a seguir. Dessa maneira nossa impressão inicial muda, especialmente quando notamos que a mãe de Wesley continua com as suas atividades enquanto ele fala. Isto nos faz inverter nossa primeira percepção da peça, uma vez que ela age como se ele não estivesse lá. A abordagem lógica é mais uma vez quebrada quando Wesley sai da cozinha e Ella fica e inicia uma conversa com ela mesma sobre o primeiro período menstrual de Emma. (p. 138)

As regras básicas de conversação são totalmente quebradas e o nosso sentido lógico de algum modo violado. Estamos certos que Ella está sozinha no palco, mas quando sua filha vem para o palco ela segue a conversa anterior que a mãe tinha com ela mesma.

A quebra de uma conversa normal está presente nos diálogos de Shepard. A peculiaridade está em que os diálogos mais parecem monólogos violentos, brutais, até, justapostos, em que as personagens trazem à tona profundos traumas, mas não alcançam a comunicação ordenada ou a interação ativa com seus interlocutores. Suas peças dificilmente seguem um fluir conversacional porque seus personagens praticamente não estão conscientes do que cada um está dizendo. Esta falta de consciência ou de domínio do discurso ordenado, incapacidade de se comunicar que isola as personagens em sofrimento incomunicável, apesar de ter origem num núcleo comum - a crise do meio oeste americano e dos papéis sociais e familiares tradicionais - às vezes aflora no palco como ação animalesca sintoma da impossibilidade de traduzir em linguagem as frustrações e a impotência - como exemplo o trabalho de Ella e a urina ou a deglutição do carneiro feita por Wesley. Estas cenas fazem parte da forma dramatúrgica que Shepard desenvolveu, habilmente, para traduzir esta crise americana numa linguagem dramática nova e impactante. Eles raramente comentam o que foi dito. A técnica de 
Shepard para criar diálogos baseia-se muito em narrativa e é por isso que a desvalorização do diálogo é tão constante em suas peças.

O outro personagem masculino que fala com ele mesmo é Weston. Nas suas conversas consigo mesmo não há introspecção; ele fala muito com ele mesmo porque está isolado da sua família: "Sempre fui o melhor em falar comigo mesmo. Sempre foi a melhor coisa. Nada como isso. Pelo menos te faz companhia.” (p. 158)

Os solos de Weston, como os de Ella, são geralmente sobre o que está acontecendo ou o que está passando em sua mente, sobre o que os cerca. Nos monólogos de Shepard, detectamos os grandes esforços de seus personagens para fazerem-se conhecidos e sentidos. Os monólogos geralmente mostram o seu isolamento e enfocam na sua impossibilidade de falar um com o outro. Através dos monólogos dos personagens seus estados internos manifestam-se e lutam para irem além das suas limitações físicas e morais. Os personagens de Shepard são tão divididos quanto as falas que pronunciam, mas ainda assim lutam para serem reconhecidos como indivíduos.

Shepard lida com suas peças de acordo com os modernos padrões da arte, desistindo da estrutura de um enredo bem feito para introduzir uma estrutura que faz lembrar a aparente desconexão de um sonho através da hipertrofia de detalhes do cotidiano e aspectos realistas. Ele abandonou os meios tradicionais de caracterização para poder introduzir personagens que representam fragmentos da humanidade. Ele faz uso de uma linguagem dramática na qual ele manipula os diálogos e indica a disposição das cenas construindo assim um espaço simbólico, mas essa linguagem é tão fragmentada quanto os personagens que ele põe em cena, rica em apresentação de contradições que são inerentes aos seres humanos, pois são contadas na forma específica de conflitos no meio-oeste americano do pós-guerra.

Shepard descobriu em seus temas e forma uma adequada metáfora para descrever a vida contemporânea. Ele é habilidoso ao explorar as paixões humanas e o duradouro conflito entre desejo por liberdade e por raízes, por si mesmo e pela comunidade, por escapar e pela família. Ao fazer os espectadores enfrentarem suas necessidades paradoxais, Shepard provavelmente percebeu que não importa o quanto essa confrontação possa desorientar, ela também pode liberar.

\subsubsection{Curse of the Starving Class e o fracasso americano}

Porque a sua visão da identidade americana é falha e inacessível na cultura moderna, os americanos falharão em suas tentativas de alcançar o caráter nacional americano. Como eles não conseguem abandonar a busca pela identidade, tanto individual como nacional, eles acabam presos num ciclo vicioso de busca desesperada e fracasso. Weston pode ser considerado o representante desse fracasso americano. Curse of the Starving Class é a peça de Shepard que mais diretamente examina o colapso do 'sonho americano', e Weston incorpora a ruína desse 'sonho' em vários níveis. Sua família pode ser vista como o microcosmo da busca auto-destrutiva pela identidade americana: o pai, a figura autoritária, tenta impor sua identidade nos filhos ao explicar sobre o veneno ancestral que corre em suas veias; um dos filhos tenta escapar e é destruído; o outro tenta adotar a conduta do pai e acaba repetindo os pecados do mesmo fazendo com que o ciclo continue. 
O patriarca da família, Weston exemplifica a fuga desejada da terra americana e revela uma desilusão implícita em relação ao caráter nacional. Ele fracassa ao tentar realizar qualquer uma das condições da identidade estadounidense, um fracasso que já começa com a unidade básica social da família. Sua insatisfação com a vida familiar é evidente: a peça inicia exatamente com a sua ausência. Depois de uma noite de bebedeira, Weston volta cedo e descobre que foi trancado do lado de fora e raivosamente destrói a porta da frente. Então antes mesmo de aparecer no palco, o temperamento violento de Weston e sua inabilidade em ser o protetor da sua família são reveladas. A peça continua e mostra o seu fracasso em exercer a função de patriarca, pois só oferece ameaças ao invés de segurança. Quando ele descobre que sua esposa Ella não está em casa, ele exige saber onde ela está gritando: "Don't try protecting her! There's no protection! Understand! None!" (p.165). Ao invés de oferecer a proteção que a família supostamente oferece aos seus membros, Weston aterroriza a sua, tornando-se mais uma ameaça do que um guardião. Sua atitude força a família a procurar proteção fora da unidade nuclear, Ella: "[Weston] can't hurt me now! I've got protection! If he lays a hand on me, I'll have him cut to ribbons!" (p.173) Seus filhos sentem um certo temor pelo pai, tanto Emma quanto Wesley reagem a presença de Weston querendo fugir do palco.

Além da sua inabilidade em prover conforto físico e proteção para sua família, Weston também falha em sustentá-los. O refrigerador permanece a maior parte do tempo vazio. Numa das suas voltas para casa ele traz alcachofras, as quais Ella joga fora, astutamente observando: "It's a joke bringing artichokes back here when we're out of food" (p. 171) $\mathrm{E}$ até mesmo quando Weston renasce e tenta criar uma atmosfera melhor para família, ele vai para cozinha preparar um café da manhã com ovos e presunto para seu filho, mas no final acaba comendo toda comida que preparou. Weston acaba se tornando mais um parasita do que um patriarca, e quando a família mais precisa dele ele os abandona, para "start a whole new life" no México (p. 194).

Podemos perceber que os desejos de escapar de Weston estão mais relacionados aos seus problemas legais do que a sua situação familiar caótica. Ele tomou emprestado dinheiro para comprar terras, porém acabou descobrindo que elas eram no deserto. Fugir para o México parece ideal para Weston, pois não é os EUA. Ele pensa que pode mudar sua identidade e começar novamente, criando uma vida lá que ele não podia manter na América. Wesley parece mais descrente da possibilidade de escapar (apesar de ter expressado certo desejo de ir para o Alasca), mas Weston o convence de que uma vida nova o aguarda no México. O impulso escapista de Weston também tem fundamentos ideológicos. Ele fracassou em alcançar a identidade americana (mesmo que tivesse alcançado esse aspecto ideológico da identidade americana, ainda assim seria infeliz); durante a peça Weston sistematicamente falha: como proprietário de terras, como homem de negócios e com pai de família. Todos os fracassos de Weston estão enraizados na sua inabilidade em fazer suas terras serem lucrativas. Não consegue fazer seu rancho de abacates no Oeste americano produzir nem literalmente, nem financeiramente. Embebedado, ele acaba vendendo suas terras para Ellis para ter dinheiro para pagar seus empréstimos, o que não deixa de ser uma ironia, pois ele vende o rancho da família que tem seu valor e um potencial para ser produtivo para pagar por uma terra improdutiva. Quando fala com Wesley, Weston descreve a terra que ele comprou:

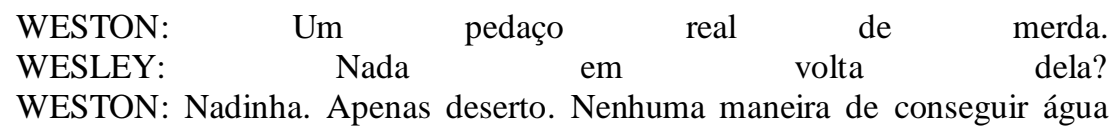


para esse lugar maldito. Nenhuma maneira até mesmo de botar um trailer no terreno. (p. 158-59)

Weston parece ser o único a não perceber o potencial da terra que possui. Ellis fala que o rancho é um lugar cheio de potencial (p.177) ao inspecioná-lo. Taylor também faz a mesma observação (p.153). E quando Weston pergunta a Wesley o que ele acha do rancho, Wesley responde: "I wouldn't sell it. [...] It's just here. And we're on it. And we wouldn't be if it got sold" (p. 166). A sua resposta é prática, mas revela uma compreensão da importância da posse da terra como um meio de sustento. Esta importância talvez seja mais simbólica que real, correspondendo a um passado em que era possível ao pequeno proprietário extrair dela seu sustento e sua autodignidade, ela fundava sua imagem social e pessoal. A crise e a mudança de rumos da economia são obstáculos novos que ele deveria superar para sua sobrevivência, mas incapaz disso, fica preso a valores antigos, não se adaptando ao novo mundo. Ella relembra Weston que ele arruinou o rancho e que abandonou sua terra e sua família.

Weston mostrou-se inapto nos negócios por não saber utilizar a terra para produzir como ao comprar terra no deserto. Ella está consciente sobre essa inaptidão quando fala para Wesley: "Another shrewd business deal" (p. 172) apesar de ela mesma ter sido enganada por Taylor. As negociações de Weston também revelam seu fracasso como pai de família. Seu desejo de vender o rancho acaba deixando a família sem um lugar para morar, o que ilustra sua inabilidade em manter a família unida.

É como viver em um covil de víboras! Espiões! Conspirações nas minhas costas! Estou sendo levado para um passeio por cada um de vocês! Eu sou o único que trabalha! Eu sou o único que traz comida para casa! Esta é minha casa e estou vendendo este casa! E eu estou pegando todo o dinheiro porque me pertence! Todos vocês me devem isso! CADA UM DE VOCÊS! (SHEPARD, p. 169)

Essa explosão de Weston expõe sua inabilidade em funcionar como o centro da unidade familiar. Essa fala confirma seu fracasso como pai e marido. Essas ações iniciam no momento que as cortinas sobem e a luz acende, Wesley está limpando os pedaços da porta da frente, a qual Weston havia destruído na noite anterior. Tanto literalmente quanto simbolicamente, a destruição da porta representa a falta de proteção que ele oferece para família.

Num momento de epifania enquanto Weston anda pelo rancho, ele percebe que tudo que ele sempre procurou estava ali mesmo no rancho onde ele e a família moram. Weston revela muito sobre sua busca por um senso de auto-identidade e como isso está conectado a algo mais amplo que o individuo:

Eu comecei a pensar que estava caminhando no pomar, às seis e meia da manhã. Eu não me sentia como eu mesmo. Era algum personagem vestindo um casaco escuro. [...] Não me sentia como o proprietário de um pedaço de uma propriedade tão agradável como esta. Então eu comecei a me perguntar quem foi o proprietário. Quero dizer, se eu não me sentia como o dono, então quem era o dono? [...] E aí me ocorreu que eu realmente era o dono. Que de alguma forma era eu e eu era realmente aquela pessoa andando no meu próprio pedaço de terra. E aquilo me causou um sentimento muito bom. (SHEPARD, p. 185) 
A conexão entre o homem e a terra fica explicita aqui. Weston fica deslocado a maior parte da peça e distanciado de todos a sua volta. Ele se isola da família e da sociedade perdendo a percepção de quem é. Mas quando ele examina a terra, ele renasce. Uma vez que ele reconhece seu status de proprietário, ele recupera a habilidade de compreender sua personalidade e recriar sua identidade.

Depois dessa comunhão espiritual com a terra, Weston demonstra sua vontade de reinvestir no sonho americano; numa versão incompatível com os novos tempos, a nova economia, a explosão urbana etc. sua aposta é numa espécie de utopia regressiva, o bom tempo de antigamente, que é uma quimera inalcançável. Ele busca um elo com a família e sua terra. Weston exibe um interesse recente na sua família depois da sua volta pelo rancho, uma experiência que o convence da natureza interconectada dos membros familiares como o centro da roda na sociedade.

E eu senti que conhecia cada um de vocês. Cada um. Como se eu os conhecesse através da carne e sangue. Como se nossos corpos estivessem conectados e nós nunca poderíamos escapar disso. Mas eu não sentia vontade de escapar. Eu senti como se fosse uma coisa boa. Era bom estar conectado assim. Que uma família não era apenas uma coisa social. Foi uma coisa animal. Foi uma razão da natureza que estávamos todos juntos sob o mesmo teto. Não que a gente tinha que estar, mas que deveríamos. E eu comecei a me sentir feliz por isso. Eu comecei a me sentir cheio de esperança. (p.186)

Weston passa a acreditar que o rancho pode ser a chave para reconectá-lo a um sentido de comunidade nacional mais amplo, que o identificaria como um fazendeiro americano, um homem que produz sustento e sucesso financeiro da terra que ele lavra. Depois do seu renascimento, Weston comenta com Wesley sobre o potencial do rancho:

Então, eu estava pensando naquela negociação sobre abacates que você estava falando antes! Você sabe, juntar-nos com "Associação Grower" e tudo mais! E eu estava pensando que pode não ser um negócio tão ruim, afinal! [...] Nós poderíamos pegá-los e vendê-los direto para a empresa! [...] Não seria preciso muito para fazer a operação toda funcionar a todo vapor de novo! Vou revender aquele pedaço de terra! Isso vai nos dar alguma coisa para iniciarmos o negócio! (p. 186-187)

Weston sente o otimismo de um homem que encontrou a si mesmo após perceber o prospecto da terra cheia de potencial. Seu relacionamento revitalizado com a terra permite a ele criar um laço com uma comunidade mais ampla. $\mathrm{O}$ empenho irônico de Weston ilustra o paradoxo da identidade americana que consome tantos personagens de Shepard. Ele parece genuíno no seu desejo de mudança. Porém, como ele não consegue separar sua identidade individual de uma imagem incompleta e falha do caráter americano, suas chances de sucesso parecem pequenas.

Weston, assim como muitos dos personagens de Shepard, estão fadados ao fracasso na sua tentativa de buscar uma identidade estável e coerente. As suas intenções finalmente parecem boas no final da peça; seu impulso para escapar vai além do seu desejo de tentar abraçar sua recém encontrada visão do caráter americano. Ele abandona sua família sem nem mesmo um adeus, deixando-os enfrentar os credores.

Os demais membros da família continuam sua inclinação para uma ruína autodestrutiva. Emma e Wesley representam a situação paradoxal que viver nos EUA gera e o impulso escapista que ela alimenta. Emma tenta escapar da América tanto 
abandonando suas fronteiras quanto os seus princípios. Ela quer negar sua herança ao renunciar seu nome de família e criar uma nova identidade para ela mesma no México. Ela elabora um cenário imaginativo para sua nova vida:

Eu estava traçando meu caminho ao longo da costa, parando em todas as cidades pequenas, de língua espanhola. Eu estava indo para aprender a ser uma mecânica e trabalhar em veículos de quatro rodas que quebraram. [...] Então eu ia aprender a ser uma cozinheira e escrever novelas. [...] Então, eu teria meus trabalhos publicados e desapareceria no coração do México. Assim como aquele

ELLA:
EMMA: Esse cara que escreveu Tesouro de Sierra Madre. [...] Ele tinha as iniciais como nome. E ele desapareceu. Ninguém sabia para onde enviar seus rendimentos. Ele escapou. (p.149)

Os comentários de Emma espelham o desejo de desaparecimento por completo evidente em muitos dos personagen de Shepard, incluindo Kent, em La Turista (Seven Plays, 1981), Henry Hackamore, em Seduced (Fool for Love and Other Plays, 1984), e Niles, em Suicide in B-Flat (Fool for Love and Other Plays, 1984). As suas tentativas de escapar são bem literais. Primeiro ela tenta escapar num cavalo que acaba arrastandoa na lama e depois no carro da família que explode, provavelmente com ela dentro. Todas suas tentativas para escapar fracassam por completo e por fim tornam-se destrutivas.

Wesley reage de uma maneira oposta à de Emma. Ele firmemente acredita nos valores americanos: a posse da terra e a auto-suficiência. Assim que as cortinas sobem, Wesley está limpando os destroços da porta da frente que havia sido destruída por Weston na noite anterior ao passo que no segundo ato abre com Wesley construindo uma nova porta. Fica claro que Wesley é o protetor da casa. Sua crença em auto-suficiência o leva a ser o único membro da família que é capaz de reconhecer que a terra que eles possuem pode ser um meio para o sucesso financeiro, assim como um caminho que os conectará com a identidade nacional americana:

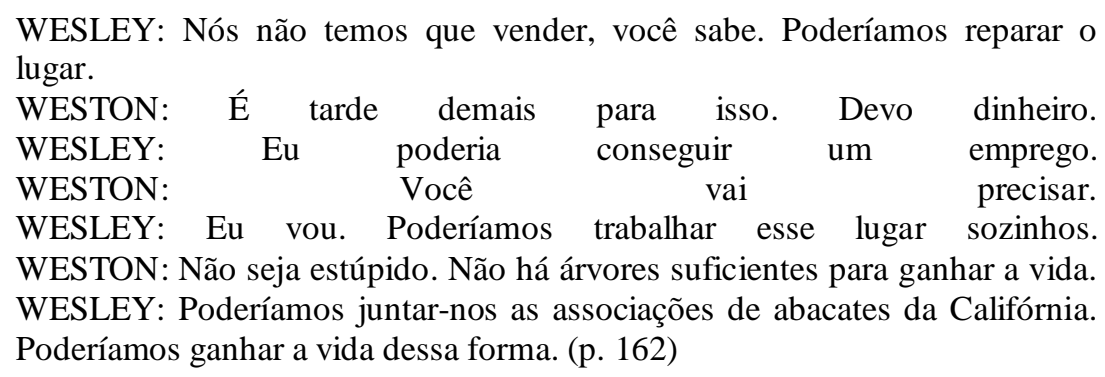

O desejo de Wesley de abraçar os princípios da identidade americana o força a tentar protegê-la da destruição. Ele reconhece que a perda da terra (a qual tanto Weston quanto Ella, individualmente planejam vender) simboliza a perda de um modo de vida na América, o 'Oeste Verdadeiro' que Shepard idealiza em muitas das suas peças:

WESLEY: Você não entende o que está acontecendo ainda, não é? EMMA: Com $\quad$ o quê? WESLEY: A casa. Você acha que é o Sr. e a Sra. América, que vão comprar este lugar, mas não é. É o Taylor. [...] Ele trabalha para uma agência. Desenvolvimento da terra. EMMA: 
WESLEY: Então isso significa mais do que perder uma casa. Significa perder um país. (p. 163)

Wesley explicitamente conecta a propriedade da terra com o caráter americano. E Ele claramente sente que a invasão do desenvolvimento e o crescimento urbano ameaçam a existência americana idílica.

Wesley teme a rápida expansão da urbanização e expressa um desejo de escapar, mas ao mesmo tempo ele não quer abandonar os EUA. Ele procura pelos últimos territórios americanos remanescentes que mantenham o espírito pioneiro, o Alasca: "the frontier. [...] It's full of possibilities. It's undiscovered." (p. 163). Se o rancho for vendido, Wesley irá direcionar-se para os territórios e reivindicar o espírito americano.

Enquanto Wesley tenta abraçar a identidade americana ele comete os mesmos erros que seu pai e atrai para si a própria desgraça. O final de Wesley parece inevitável assim que ele veste as roupas que seu pai vestiu antes do seu renascimento. A cada peça de roupa de Weston que Wesley veste, "it seemed like a part of him was growing on me. I could feel him taking over me" (Curse of the Starving Class, p. 196). Num determinado momento (Curse, p. 197) Ella confunde Wesley com seu pai, chamando-o de Weston:

\section{ELLA: (para WESLEY) Weston! Foi a Emma?}

WESLEY: Sou eu, mamãe. (p. 197)

Quando Ella identifica Wesley como Weston sugere que o filho está fadado a continuar o ciclo de fracasso que começou em gerações anteriores. Emma aponta hereditariedade como o problema: "It's chemical. [...] Something in the blood. Hereditary. Highly explosive. [...]. In the blood. Nitroglycerine.” (p. 152) Weston rotula o problema como 'veneno', mas acaba chegando à mesma conclusão. Insinuando que Wesley sucumbirá ao mesmo destino que ele, Weston diz para Wesley, "I never saw my old man's poison until I was much older than you. [...] I saw myself infected with it. [...] I saw me carrying it around. His poison in my body." (p. 167). Na mesma conversa Wesley revela sua consciência sobre a inevitabilidade do seu destino:

WESLEY: Eu sei que está lá, porém não sei o que é.

WESTON: Você irá descobrir. (p. 168)

Quando mais tarde Wesley aparece vestindo as roupas de seu pai seu destino torna-se evidente. Weston exige saber o por que Wesley está vestindo "clothes that've been thrown-up in, pissed in, and God knows what all in"; Wesley responde: "they fit me" (SHEPARD, p. 191).

Wesley está tão condenado quanto Emma. Abraçar a identidade americana resulta nas mesmas consequências fatais que tentar fugir dela. Das duas maneiras o impulso escapista nunca pode terminar satisfatoriamente. Os personagens de Shepard continuarão a tentar uma forma de fuga ou outra, e ainda assim ambos os esforços permanecerão fúteis e autodestrutivos.

\subsection{Buried Child: Tabus universais: sexo (incesto), vida e morte}




\subsubsection{Buried Child - a peça}

Inicio agora a análise de Buried Child, uma peça de três atos que foi primeiramente produzida e encenada no Magic Theatre de São Francisco em 1978 e ganhou o Pulitzer Prize em 1979, e que tem muito em comum com Curse of the Starving Class analisada no capítulo anterior. Essa peça também se refere ao fracasso familiar, mas de uma família mais velha, mais habituada ao seu destino. Dodge, Halie, e seus filhos adultos, Bradley e Tilden moram numa fazenda em Ilinois onde nada cresce. Uma visita de Vince (filho de Tilden) e sua namorada Shelly proporciona o catalisador para revelação dos segredos familiares há muito enterrados. Tanto em Curse of the Starving Class como em Buried Child, temos personagens que consomem bebidas alcoólicas. Como Sharon Wegscheider (1981, p. 87) observa: "Cada papel cresce do seu próprio tipo de dor, tem os seus próprios sintomas, oferece os seus próprios desenlaces tanto para o indivíduo quanto para a família, e em última análise exige seu próprio preço".

Buried Child inicia-se com Dodge 'nos seus setenta anos' (sozinho no palco) e bebendo escondido dos outros, e conversando com Halie que está no andar de cima. Tilden, 'o filho mais velho deles', entra com os braços cheios de milho que ele menciona ter colhido no 'terreno do fundo' onde seus pais dizem que nada cresce. Espalhando conselhos e recriminação, Halie parte para almoçar com Father Dewis que segundo ela está planejando erguer um monumento em homenagem a Ansel, "heroicamente" morto. Dodge adormece e Tilden o cobre com as palhas de milho. Pega sua garrafa que estava escondida e sai. Bradley, descrito como "o próximo filho mais velho, um amputado", entra e encontra-se sozinho com Dodge, corta o cabelo dele com o cortador elétrico enquanto ele dorme.

O Ato II começa naquela noite com a entrada de Shelly e Vince. Ele está ansioso para causar uma boa impressão e ela convulsionada em risos ao ver a atmosfera de Norman Rockwell $^{6}$ da casa. Dodge está sozinho e ainda dorme. Quando ele acorda, ele não reconhece Vince o que perturba os dois jovens, e apesar de Shelly querer partir, Vince insiste para ficarem. Tilden entra e dessa vez com os braços cheios de cenouras, mas ele também não reconhece Vince. Dodge, desesperado para reaver sua garrafa, tenta primeiro convencer Tilden depois Vince a comprar uma na cidade. Vince concorda em ir e deixa Shelly limpando cenouras. Tilden e Shelly conversam enquanto ela trabalha e ele conta para ela a história, já insinuada várias vezes, do bebê que Dodge afogou. Dodge, ao tentar impedir as revelações de Tilden, desmorona no chão num ataque de tosse. Bradley entra, afugentando Tilden, intimidando Shelly num estupro simbólico: ele a força a ficar parada de pé com a boca aberta e "com sua mão livre ele enfia seus dedos na boca dela" (SHEPARD, 1981, p. 107).

O Ato III inicia-se na manhã seguinte. Halie, Vince e Tilden ainda não voltaram; Bradley, sem sua prótese, está adormecido no sofá, e Dodge permanece no chão. Shelly tenta conseguir uma confirmação de Dodge sobre a estória que Tilden contou para ela,

\footnotetext{
${ }^{6}$ No mundo retratado por Rockwell a vida é linda e boa de ser vivida, as crianças são felizes e as famílias amorosas. Rockwell nos faz pensar que o mundo deveria ser como as suas ilustrações e aí reside o seu encantamento: dá-nos saudades de algo que nunca aconteceu. Norman Rockwell nasceu em Nova York em 1894. Sempre quis ser artista e quando tinha 14 anos começou a estudar na Escola de Arte de Nova Iorque e aos 16 passou a frequentar a Academia Nacional de Design para depois ingressar na Liga de Estudantes de Arte. Comecou sua vida profissional aos 16 anos, pintando cartões de Natal e ainda adolescente tornou-se diretor de arte de uma revista americana para meninos escoteiros chamada Boy's Life.
} 
ou ao menos entender a história da família. Halie, com seus braços cheios de rosas, entra com Dewis. Halie intimida Dodge e Bradley, que começa a choramingar como uma criança, mas Shelly a enfrenta e traz à tona o segredo. A família manobra freneticamente para defender "o pacto" de manter sigilo, mas Dodge decide contar para Shelly tudo sobre o que aconteceu. Bradley não consegue parar Dodge; Shelly mantém sua perna artificial fora do alcance dele. No final da narrativa de Dodge, "Eu o afoguei. Como o menor e mais fraco animal de uma ninhada", Vince espatifa-se na varanda, incrivelmente bêbado e quebrando garrafas contra a parede da varanda. Agora seus avos o reconhecem. Halie escapa para o andar superior e Dodge, declara oficialmente um testamento verbal, proclamando Vince como seu herdeiro. Shelly sai, mas não antes de Vince explicar que aceitará a herança que ele reconheceu como sua, nas faces atrás da face dele refletida no pára brisa do carro. Bradley se arrasta até os bastidores seguindo a perna que Vince jogou para fora do palco e Dewis sai negando qualquer conhecimento prévio de problema na casa. Dodge morre sem ninguém notar no chão e Vince ocupa o lugar de seu avô no sofá. Assim que Halie descreve o "paraíso" crescendo de repente nos fundos da casa, Tilden aparece carregando um cadáver de uma criança todo enlameado e sobe as escadas para levá-lo até sua mãe.

Como ele fez em outras de suas peças anteriores, Shepard coloca questões para as quais ele recusa-se a dar respostas definitivas. Apesar da revelação do segredo familiar ser amplamente prenunciado, quando ele vem à tona ainda é deixado inexplicado. Shepard aumenta, e depois confunde nossas esperanças por uma explicação satisfatória. Shelly é uma substituta, uma forasteira, cuja curiosidade, assim como a nossa, exige uma satisfação. Como Lynda Hart (1987, p. 76) expressa:

\begin{abstract}
Apesar de em Buried Child Shepard intencionalmente preparar a platéia para seguir as pistas atormentadoras que ele exibe num esforço de integrar os fragmentos num todo completo, ele enfraquece nossas expectativas, frustrando nossa habilidade para resolver a ação da peça realisticamente, alegoricamente, ou simbolicamente.
\end{abstract}

Enquanto alguns críticos, Hart entre eles, analisa a peça como um exemplo de realismo modificado, outros acreditam que Buried Child é mais bem abordada não realisticamente.

Christopher Brookhouse (1988) e Bruce Mann (1988) usam modelos literários, o fantástico e contar histórias respectivamente, para explicar a peça. Gay Gibson Cima (1986) usa a estética de Robert Rauchenberg para sugerir que os personagens em Buried Child sejam abordados sem as "habituais associações psicológicas e éticas do termo 'personagem'..." (p. 76) Cima argumenta que os personagens de Shepard podem ser mais bem analisados como "figuras/imagens", obviamente construídos e "descobertos espontaneamente no momento, deslocados de outros contextos e colados juntos como colagens de imagens ou palavras, 'combinações' de imagens e linguagem” (p. 76). Usando essa abordagem, Cima conclui: "Shepard apresenta duas figuras para platéia, ambas foram identificadas como o filho de Tilden e podem ser compreendidas como o personagem Vince" (p. 77). Na visão de Cima, Shepard usa as armadilhas do realismo de Ibsen somente como uma moldura/estrutura para o seu projeto não realístico.

Muitos críticos explicam Buried Child como uma alegoria. O assunto da alegoria de Shepard é variavelmente visto tanto como o fracasso do 'sonho americano', como a condição humana moderna, ou ambos. Thomas Adler afirma que Shepard está 
"alegorizando a experiência americana... mostrando o novo Adão americano como o autor de uma nova queda" (Mirror on the Stage, 1987, p. 107). Johan Callens, que adota uma abordagem freudiana da peça, diz que Shepard "funde a luta da família contra sua própria culpa com o maculado 'sonho' da nação e, ao vivissecar o subconsciente da família, ele explora o passado mítico e coletivo da nação" (p. 406). Rodney Simard adota uma visão mais geral:

\begin{abstract}
Apesar de todas as peças de Shepard poderem ser consideradas como poéticas prolongadas e metáforas simbólicas, Buried Child é seu primeiro trabalho concreto de alusão dramática consciente. Construído em torno do lugar comum e habitual, a peça é arquetípica na sua estrutura, incluindo diversas camadas de significado simbólico e funcionando como uma dramatização pós-moderna de The Wasteland (ELIOT, T. S., 1922).
\end{abstract}

C.W.E. Bigsby (1985, p. 242) afirma sobre Buried Child que "a ação alegórica implica na implacabilidade da natureza humana, evidência que constantemente vem à tona".

Muitos outros críticos também se referem à natureza arquetípica dos personagens e lutas em Buried Child. Dóris Auerbach, Thomas Adler e outros vêem a luta de pai contra filho e irmão contra irmão como ligando a peça a mitos antigos e a temas como pecados do pai atacando seus filhos, ou "um rei doente governando uma terra empesteada e amaldiçoada", (PATRAKA e SIEGEL, 1985, p. 40). Laura Shea (1984, p. 13) argumenta que Buried Child pertence a tradição de Édipus na qual a vítima é sacrificada com o fim de: "desviar a violência implodindo dentro da família [ou da sociedade]".

Os símbolos e imagens que Shepard usa nesta peça induzem tais interpretações: quando Tilden enterra simbolicamente Dodge debaixo das palhas do milho, o aparente crescimento mágico das colheitas, o retorno do(s) filhos(s) pródigo(s), o cadáver ressuscitado da criança. Incorporando esses mitos, abaixo e atrás da alegoria, entretanto, está uma família infectada pelo álcool nos seus últimos estágios de decadência.

A multiplicidade de interpretações abre para qualquer um que assista ou leia Buried Child existindo e desenvolvendo-se a partir do que é deixado inexplicado ou é inexplicável na peça. O cenário, em contraste com o sem enfeites, de Curse of the Starving Class, está descrito pelo dramaturgo com detalhes realísticos. Não existem intervalos abruptos na ação, nem forasteiros bizarros ou não esperados como gangsters ou répteis como em outras peças, ainda assim nunca sabemos, ao certo, no que ou em quem acreditar. O que a dramaturga Jane Crum chama de "lágrimas no feitio da realidade", vem das ilógicas e irreconciliáveis contradições nas histórias que os personagens contam, mais complicadas por contradizerem o que assistimos no palco. $\mathrm{O}$ milho e as cenouras que Tilden traz para o palco são bem reais. Isso significaria que Dodge e Halie estão mentindo sobre nada crescer nos fundos da casa? Será que há na realidade um milagre de regeneração acontecendo? Qual versão do infanticídio é a "real"? Será que o bem vivo Vince e o cadáver enlameado é o mesmo personagem, como Callens e Gay Gibson Cima acreditam? Ou é a verdade menos concreta e misteriosa? Ron Mottran (1984, p. 140) conclui: "Na análise final, a criança enterrada do título significa um conjunto de atitudes e relacionamentos familiares mais do que um indivíduo ou um evento em particular do passado".

Se a peça é tomada principalmente como alegórica ou julgada estar mais fundamentada no realismo, a família é o veículo que Shepard usa para colocar seus questionamentos. 
Não é qualquer família, ou toda família, mas uma nitidamente e admitidamente moldada na de Shepard. A fazenda em Illinois pertencia aos avôs de Shepard, a avó e o avô sobre os quais ele escreve, ele os visitava quando era um jovem rapaz. O pai de Shepard tinha um irmão que havia sofrido uma amputação e outro que morreu na lua de mel. Tilden, descrito no roteiro como "profundamente cansado, sem energia e deslocado", é ainda outra encarnação do próprio pai de Shepard, fugindo da sua vida no oeste americano. Ainda assim não podemos afirmar que Buried Child é uma transcrição somente de eventos reais. A história real da vida de Samuel Rogers II é narrada pelo filho numa entrevista com Robert Goldberg (1980), está muito mais próxima do relato dado por Pop sobre seu passado em The Holy Ghostly (SHEPARD, 1969).

Além das conexões biográficas em Buried Child, a causa das atitudes e relacionamentos familiares, sua referência assassina, é variavelmente diagnosticada por críticos como: (1) desapontamento no fracasso do 'sonho americano' (BLAU, ADLER, CALLENS), (2) a impotência do "princípio feminino... em interceder e parar a progressão interminável de um homem violento para outro" (AUERBACH, 1988, p. 54) e (3) o desespero existencial engedrado pela vida moderna (BIGSBY, 1985).

\subsubsection{Cenário idílico}

O cenário é aparentemente idílico. Pessoas trabalhadoras na área rural com uma moralidade sólida onde a vida é simples, os valores são fortes e a vida é boa. Quando Vince chega, a América urbana encontra a América rural. A peça se passa em Illinóis, no cinturão do milho, no coração da América. O milho é um dos principais símbolos da peça. A casa da fazenda está dilapidada, mas já foi próspera. Dodge nos diz: "éramos bem estabelecidos. A fazenda produzia leite suficiente para encher o lago Michigan duas vezes... Nada é plantado aqui desde 1935".

O sofá predomina no cenário, além da televisão, das escadas e da varanda. A televisão e a varanda sugerem uma América dos anos 50, enquanto que as escadas sem um patamar sugerem o mistério de Halie, talvez sobre o passado desconhecido dela. Os monólogos dela e suas entradas das alturas fora do palco contribuem para estranheza da peça. A varanda é o contato com o exterior e talvez possa estar relacionada a uma fuga da casa. Estamos sempre sendo informados sobre o que acontece do lado de fora da casa: o barulho constante da chuva nos dois primeiros atos, as referências ao sol, a entrada dos personagens molhados pela chuva, e o milho e as cenouras que crescem em abundância e são trazidos para dentro por Tilden.

O tempo é usado classicamente na peça, pois os eventos cobrem 24 horas. Entretanto, a terra do lado de fora produz colheita após colheita nas mesmas 24 horas, e no final o corpo da criança enterrada. Podemos dizer que o tempo do lado de fora da casa é surrealista, e Shepard tece uma rede com o surrealismo e o realismo, cada vez que Tilden carrega cada colheita para a sala e finalmente a criança enterrada.

A peça lida com assassinato e seus efeitos numa família cheia de dor e disfuncional do meio oeste americano. Shepard combina vários elementos pós-modernistas usando histórias conhecidas, mitos e símbolos. Édipo, o retorno do filho pródigo e o mistério do assassinato criam o enredo de Buried Child. A aparência inicial da peça é de realismo tradicional, mas elementos expressionistas são construídos no decorrer da peça e no 
terceiro ato o surreal é dominante. Várias questões sobre o enredo da peça ficam sem respostas e o fim é bastante incerto.

\subsubsection{Imagens visuais}

As imagens são notáveis e frequentemente chocantes. Um homem velho sentado no sofá no escuro com a luz azul da televisão piscando na sua face; Tilden debulhando milho no meio do palco, e enterrando seu pai com ele; o brutamonte e violento Bradley numa perna só atacando a cabeça do próprio pai com um cortador; enfiando sua mão na boca de Shelly; Tilden circulando em volta de Shelly e as cenouras como um animal feroz; Bradley chorando e pedindo a ajuda de Halie, contorcendo-se atrás da sua perna de pau; Vince violentamente quebrando as garrafas e cortando e caindo através da tela; a marcha inexorável de Tilden escada acima com o corpo apodrecido da criança em seus braços.

A peça apresenta uma estrutura tradicional de três atos: os personagens e os conflitos são estabelecidos no primeiro, o conflito piora e o antogonista fica mais forte no segundo, sendo o conflito solucionado no terceiro. Shepard combina as histórias do filho pródigo, do qual Vince é o protagonista; e uma história de mistério, cujo protagonista é Dodge, usando eventos reais e surreais. A peça termina com um movimento circular com a volta de uma figura como Dodge sentado no sofá (Vince). $\mathrm{O}$ diálogo e a linguagem são repletos de repetição, fragmentos e emoção. Shepard afirma na sua versão de 1978 da peça que a linguagem encaixa-se nos personagens e que existem poucas lacunas entre os personagens e suas falas.

Se considerarmos que a chuva e a água são símbolos de limpeza, em especial no universo bíblico, percebemos no início de Buried Child, que a chuva cai pesadamente na casa da fazenda e nos visitantes, lavando o passado sujo. No terceiro ato, um novo dia amanhece; a mentira é exposta, o assassino morre, Vince torna-se o chefe da família.

Observamos alguns rituais na peça que repetem certos padrões de conduta como o de sepultamento e do milho. Dodge, o moribundo, é enterrado várias vezes. Primeiro coberto com espigas de milho e depois com palha de milho. Mais tarde ele é coberto com um casaco de pele que pertence a Shelly, e no final, depois da sua morte silenciosa passar despercebida, Halie coloca um cobertor sobre sua face e rosas no seu peito. Os ritos de sacrifício assemelham-se rituais de colheita primitivos para abençoar a terra e as sementes para satisfazer vários deuses. A sociedade sempre se preocupou com comida, os gregos adoravam Demétrios, os índios americanos desenvolveram as danças do milho e os americanos celebram o dia de Ação de Graças. Podemos afirmar que um dos mais importantes rituais dramatizado em Buried Child é a morte do velho rei do milho e o nascimento e ressurreição do novo rei. Dodge seria simbolicamente o rei do milho, desamparado e esperando pelo novo e mais forte rei do milho que o substituirá sendo que o clímax da peça é atingido quando Dodge morre e Vince o substitui, assumindo o trono. Tilden pode ter sido deposto dessa posição quando engravidou a mãe e Bradley poderia assumir o papel, mas foi simbolicamente castrado.

Vince aparece no Ato II para sinalizar a chegada de um potencial novo rei do milho, jovem e forte. Talvez reconhecendo a seriedade da ameaça que Vince representa tanto Dodge quanto Tilden assumem não reconhecê-lo. Mais tarde Vince retorna à casa depois de dirigir na chuva purificadora, corta seu caminho através da tela da porta 
trancada da varanda irrompendo, como um bebê emergindo do útero da mãe. Shepard claramente utiliza esse momento dramático como um renascimento simbólico, calculado para corresponder ao exato momento que Tilden, sozinho na chuva, deve estar desenterrando o cadáver da criança enterrada da lama dos campos de milho. Vince retorna bem a tempo da nova estação, assume a casa e os campos e torna-se o novo rei do milho. Do lado de fora, depois da chuva purificadora e dos nutrienes da luz solar a colheita floresce nos campos e o novo rei do milho rei do seu trono no sofá.

A corrupção familiar é um dos temas da peça. Alienação e dissociação são experimentadas por todos os membros da família, pois eles sofrem a sina do pai, Dodge, que nega a realidade, e, portanto sua verdadeira identidade. Todos os personagens são mutilados de uma maneira ou outra. Sua dissociação é tão extrema, que são incapazes de reconhecer Vince, um membro da família, que chegou buscando pela sua verdade, sua própria identidade. Todos os personagens precisam da chuva purificadora. Os problemas do passado estão sempre conosco no presente e pagamos pelos pecados dos nossos pais para sempre. Porque o passado se fez presente, o passado é de alguma maneira o presente. Parece-nos que Vince, deitado como Dodge no sofá no final da peça, agora consciente e escolhendo sua família será como Dodge. O final da peça é um retorno ao início, sugerindo que o passado sempre estará com a família.

Os personagens nas peças de Sam Shepard nos dizem tudo sobre eles mesmos, ao invés de termos outros personagens falando sobre eles. Os principais personagens de Shepard já têm uma vida interior. Então o ator está livre para reproduzir os momentos da peça. $\mathrm{O}$ personagem realista típico tem que interpretar as falas do texto dramático, enquanto que na transformação radical de Shepard do realismo o personagem interpreta fragmentos, vazios, transformações.

Os personagens em Buried Child são na maioria unidimensionais e vivem como num pesadelo; entretanto, Dodge e Vince são mais complicados, e algumas vezes, realistas.

\subsubsection{O patriarca Dodge}

A bebedeira de Dodge é sinalizada pela primeira ação da peça. As luzes são acesas e revelam o velho homem sentado no sofá olhando fixamente para televisão.

Ele vira sua cabeça vagarosamente para esquerda e olha fixamente para a
almofada do sofá próxima da que ele está sentado. Ele tira seu braço esquerdo
debaixo do cobertor, enfia sua mão embaixo da almofada, e tira uma garrafa
de uísque. Ele olha para baixo, do lado esquerdo em direção a escada, ouve
atentamente, então abre a garrafa, toma um longo trago e a fecha novamente.
(p.64)

O primeiro som que ouvimos é Dodge tossindo, o segundo é a voz de Halie lá de cima, oferecendo uma pílula para Dodge. Ele continua bebendo disfarçadamente enquanto ele conversa com sua esposa, que permanece no andar de cima. A necessidade, ou a necessidade observada, de esconder o suprimento de álcool é sintomática do 'cabo de guerra' que existe na família; para controlar a bebida, a família tenta, e fracassa, em controlar o suprimento de álcool enquanto que Dodge usa todos seus recursos para obter e protegê-lo. 
Quando Tilden, um pouco mais tarde, pede para seu pai "um pouco daquele uísque que você tem... debaixo do sofá" Dodge raivosamente nega possuí-lo:

DODGE: Eu não tenho nada debaixo do sofá! Agora cuide da sua própria vida! Deus do céu, você vem para casa saído do nada, não ouvimos falar de você ou vimos você em vinte anos e repentinamente você está fazendo acusações.

TILDEN: Não estou fazendo acusações.

DODGE: Você acabou de me dizer que eu tinha uísque debaixo do sofá! (p.71-72).

Dodge está na defensiva e com a intenção de impedir seu suprimento de ser consumido por Tilden ou confiscado por Halie.

Esse momento na peça é significante porque encapsula as condições de comunicação na família: ninguém pode discutir o que está realmente acontecendo na família, tanto uns com os outros como com os estranhos. Tanto Dodge quanto Tilden sabem que tem uísque debaixo da almofada do sofá, mas a resposta de Dodge nega essa realidade. Ao mesmo tempo, Dodge transfere a vergonha e culpa para Tilden. O tratamento de Shepard desse pequeno segredo é emblemático do milho, das cenouras, e da criança enterrada; é uma disjunção entre o que realmente está acontecendo e o que os personagens reconhecem como sendo real.

A devoção de Dodge para o álcool é muito mais intensa que seus relacionamentos com qualquer pessoa ou qualquer coisa. Ele passa a maior parte do Ato II tentando fazer com que alguém substitua a garrafa de uísque que Tilden bebeu. Dodge volta-se para Vince e Shelly quando Tilden recusa-se a ir até a cidade para buscar bebida. "Ninguém", Dodge afirma, "compreende a urgência" (p. 96). Mais de vinte dos discursos de Dodge no segundo ato são devotados a sua sede, sua necessidade de uma garrafa. Ele julga cada um dos personagens levando em consideração sua habilidade ou boa vontade em provêlo com uísque. Quando Shelly sugere que talvez Vince devesse ir até a cidade para comprá-lo, Dodge diz: "Ela é uma garota bonita. Excepcional" (p. 95). Dodge reavalia Shelly, entretanto, quando ela é contra a partida de Vince que pretende deixá-la na casa: "Não a deixe convencê-lo do contrário! Ela é uma má influência sobre você. Eu percebi isso no momento que ela pisou nessa casa" (p. 96). Quando Vince hesita em ir porque, "Tilden diz que você não deveria beber", Dodge opõe-se: "Tilden perdeu os miolos! Olhe para ele! Ele está enlouquecendo. Dê uma olhada nele”. (p. 98).

De maneira geral Dodge percebe um mundo ameaçador preenchido por pessoas hostis que querem manipular e/ou controlá-lo. Tal percepção explica a mania que ele tem de guardar segredo, sua aparente indiferença e sua hostilidade efervescente. Explica também, sua necessidade de distanciar-se emocionalmente dos outros, incluindo especialmente, sua própria família.

Encontramos esses três fatos mencionados acima em Dodge desde o inicio da peça. A distância que ele mantém da sua família e sua devoção correspondente ao álcool é reforçada visualmente e verbalmente do começo ao fim da peça. A conversa entre os andares que começa na peça é um exemplo visual admirável da separação de Dodge e Halie, uma separação que é mais que física. Nos primeiros momentos, Halie ameaça lá 
de cima, "Vou descer em cinco minutos se você não me responder!" (p. 64). Dodge responde, duas vezes, "Não desça" (p. 64). Ele imita Halie e faz comentários desagradáveis que ela não pode ouvir deste modo corroendo a superfície polida da conversa deles. Ele também não responde a ária dela enaltecendo Ansel, o segundo filho que "teria tomado conta de nós, também" (p. 73). Durante a peça, Dodge nunca menciona Ansel diretamente.

Dodge está enfaticamente distante de seu filho Bradley e desafoga sua hostilidade dizendo: "Ele nasceu em uma maldita pocilga! Lá foi onde ele nasceu e lá que ele pertence! Ele não pertence a essa casa!" (p. 76). O desprezo de Bradley pelo pai fica igualmente claro. Assim como Dodge previu, Bradley vem quando o velho está dormindo para cortar o seu cabelo, ostensivamente sem nenhuma preocupação com a aparência de Dodge, mas "Ele olha para a face de Dodge dormindo e balança sua cabeça indignado" (p. 82). O corte de cabelo que ele proporciona para Dodge: "o cortou extremamente curto e em alguns lugares o couro cabeludo está cortado e sangra" (p. 83). No Ato III, os dois se insultam e batem boca sobre o cobertor de Dodge como se fossem duas criancinhas.

Dodge também mantém distância do seu neto que irá ser seu herdeiro. Durante o Ato II, Dodge nunca reconhece Vince. Seu primeiro comentário ao vê-lo é: "Você trouxe o uísque?" (p. 87). Depois que ele percebe que Vince não é Tilden, Dodge questiona os dois jovens perguntando quem eles são e de onde eles vêm. Quando Vince se aproxima, ele diz: "Mantenha distância!" e quando Vince o chama de avô, Dodge protesta: "Pare de me chamar de avô! É repugnante. 'Avô'. Eu não sou avô de ninguém!” (p. 89-90). As palavras proféticas de despedida de Dodge para Vince quando o jovem vai pegar dinheiro para comprar 'Gold Star Sour Mash' (Jack Daniel's Old No. 7 Brand Tennessee Whiskey, Sour Mash 750 m) são: "Não vá para nenhum outro lugar. Não vá a algum lugar e beba. Volte direto para cá" (p. 99). Assim que o Ato III abre Dodge, certo de que Vince desapareceu, não está preocupado com Vince, mas com sua garrafa e com seus "dois dólares".

Dodge está mais próximo do personagem Tilden. Como foi demonstrado acima, ele não recebeu seu filho mais velho exatamente com os braços abertos, mas ele defende Tilden dos ataques verbais de Halie. Dodge parece sentir-se mais confortável com Tilden do que com qualquer outro personagem. A conexão entre pai e filho é estabelecida pela ordem formal de Halie: "Dodge! Ele não está bebendo, está? Cuide para que ele não beba nada! Você deve tomar conta dele" (p. 72).

Shepard retrata Dodge como uma vítima, e é o que ele é, mas não tem nada a ver com a idade, a conduta deplorável de Halie, desespero por ter perdido seus sonhos, ou culpa por seu crime indizível que destrói Dodge. Dodge afogou seus sonhos e seus relacionamentos assim como ele afogou a criança enterrada; ele e sua família são vitimas do sistema que eles mesmos criaram.

\subsubsection{A inconsistente Halie}

Muitos críticos vêem em Buried Child os conflitos entre o mundo do pai e o mundo da mãe. Auerbach, citado acima, observa a impotência de mães para interromper o ciclo masculino de violência. Hart contrasta "a tendência patriarcal com respeito a poder, dominação, e violência", com a "linhagem matriarcal" passiva, observando que "o 
domínio de Halie está fora do palco, não é visto, é primariamente um receptáculo para o passado" (p. 87). Callens diferencia na peça uma "dimensão mítica simbólica" incorporando "uma visão da infância e inocência original, uma união com a mãe e o mundo". Ele contrasta isso com as "preocupações realísticas" nas quais "a infância pode vir a significar ganância, possessividade e imaturidade" (p. 413). Em cada um desses julgamentos, os mundos do pai e da mãe são separados e opostos tanto em essência quanto em espaço.

Pode-se sublinhar a unidade essencial dos mundos do pai e da mãe em Buried Child; ambos são pegos no mesmo sistema e estão desempenhando papéis complementares. Os mais proferidos sentimentos de Halie são autointegridade, autopiedade, e raiva. As manifestações dessas qualidades mudam em Halie no momento que a situação no lar deteriora. Sob as pressões ou responsabilidades com a família e as exigências de morar com Dodge, ela frequentemente torna-se quixotesca, amarga, e desonesta como o esposo, uma fonte tão importante de stress, inconsistência e raiva como ele é.

Halie, como Shepard a escreveu, é todas essas coisas, e ela, como Dodge, está no final da espiral descendente, tão viciada ao seu papel quanto Dodge ao álcool.

A antipatia e desconfiança de Dodge são dissimuladamente exibidas, ao menos quando ela está em casa, enquanto os sentimentos dela por ele são expressos em extremos exagerados. Do seu quarto no andar de cima ela parece preocupada com a saúde e aparência de Dodge. Ela responde aos seus chamados com "Sim, querido!" (p. 69). Quando ela aparece na sala de estar, entretanto, e eles discutem sobre os filhos, Halie diz:

\footnotetext{
Você senta aqui dia e noite, apodrecendo! Decompondo! Infestando a casa com o cheiro do seu corpo em putrefação, perturbando a sua cabeça até altas horas! Pensando em coisas desprezíveis, estúpidas e perversas para falar da sua própria família! (p. 76).
}

O bate papo educado e os carinhos superficiais da conversa de abertura parecem possíveis somente quando Halie está no andar de cima, no quarto onde ela mantém o passado no qual ela pode viver.

Halie é igualmente inconsistente, senão perversa com seus filhos. Logo após ter lembrado Dodge, "você tem que cuidar do Tilden" e falar carinhosamente sobre ele, ela critica colericamente o filho mais velho quando a explicação dele sobre a origem do milho é insatisfatória: "Você vai ser chutado para fora dessa casa, Tilden, se você não me contar onde você pegou aquele milho!” (p. 76). Alguns momentos mais tarde ela fala sobre Tilden, "Nós temos que cuidar dele agora do mesmo modo que costumávamos cuidar. Do jeito que nos sempre cuidamos. Ele ainda é uma criança" (p. 77). Apesar de Halie falar positivamente de Bradley como um adulto no Ato I, quando os dois estão juntos no palco no terceiro ato, ela o trata como uma criança turbulenta. A sua fala mais frequente em relação a ele é "Cale a boca!" repetida seis vezes nesse ato (p. 115, 117, 121).

Um dos sintomas de co-dependência partilhado por todos da família em Buried Child, mas mais nítido em Halie, é a crença na eficácia e na necessidade de controle externo. Isto é, não é esperado que ninguém controle a si mesmo, então outra pessoa deve fazêlo. Conforme a doença progride, as tentativas fúteis de controle tornam-se obsessivas. 
Porque o problema real, o alcoolismo, não pode ser controlado e negado como a origem do problema familiar, o personagem facilitador tenta controlar tudo e todos. Como Perez (1986, p. 37) explica, "Facilitadores tendem a ser compulsivos. Sua constante e mais importante missão, entre as muitas que tem, é resolver qualquer um e todos os problemas familiares". Com a conspiração de Dodge, Halie mantém a ficção de que ela está controlando seu suprimento de álcool. Ela também o aconselha várias vezes a "tomar a pílula" na primeira cena. É Halie quem verte uma não requisitada dose de whiskey para Shelly, uma indicação forte de que Halie construiu uma base poderosa em prover ou negar álcool e uma ação que implica que ela sente-se mais segura e em controle quando lida com pessoas que beberam.

A necessidade de controlar é uma peculiaridade associada ao super protecionismo.

Pais super protetores, não amam, mas rejeitam. O pai superprotetor percebe a criança (independente da idade) como basicamente desamparada e inapta. O diálogo de Halie demonstra que ela estendeu seu julgamento de desamparo e inaptidão para incluir todos os homens; nenhum deles pode ser confiável, e cada um deles deve depender de um dos outros para assumir a responsabilidade por ele. Bradley, ela diz, sente-se responsável pela aparência de Dodge. Quando Dodge expressa seu medo por Bradley, Halie diz, "Tilden tomará conta de você... Tilden o filho mais velho. Ele irá protegê-lo" (p. 68). Ela relembra Dodge de tomar conta de Tilden, não deixá-lo beber e não permitir que ele saia. Então ela diz para o marido, "Se você precisar de qualquer coisa peça para Tilden. Ele é o mais vellho" (p. 77). No terceiro ato, as tentativas de Halie de controle tornamse desesperadas e quando elas fracassam, ela novamente tenta fazer com que os homens controlem um ao outro, dizendo para seu filho, "Bradley, faça-o calar a boca!" (p. 124). Quando Bradley não faz nada, Halie sublinha sua deficiência ao invocar o herói caído:

Ansel o teria impedido de contar essas mentiras! Ele era um herói! Um homem! Um homem por completo! (p. 124).

Cada homem apreendeu a lição externa de controle, por exemplo, Dodge tenta continuamente manter Tilden na casa e Tilden diz que ele não pode contar para Shelly "algo que é verdade", porque "Dodge não permitirá que eu o faça", (p. 103). Existe um eco do padrão familiar nas repetidas tentativas de Vince de controlar a conduta de Shelly, primeiro quando o casal chega à fazenda e mais tarde quando ela aceita a braçada de cenouras ofertada por Tilden.

Além de serem super protetores, e compulsivos, preocupam-se demais.

O que as pessoas pensam é de importância crítica. Essa preocupação obsessiva por aparências e convenções sociais é a razão principal deles terem tantas preocupações.

A preocupação de Halie por aparências e convenções sociais é expressa tanto diretamente quanto através de outros personagens. Na primeira cena da peça, ela medita no decoro de tomar a pílula: "Não é cristão, mas funciona. Não é necessariamente cristão, é isso. Não sabemos. Existem coisas que os pastores não podem nem dar uma resposta" (p. 65). Depois de um curto espaço de tempo, Dodge fornece uma pista para a preocupação de Halie por aparência. Declarando que ela colocou Bradley para cortar seu cabelo, Dodge diz: "Você tinha planejado algum encontro estúpido e extravagante! Hora de vestir o cadáver para companhia! Diminuir um pouco as orelhas!" (p. 67). Quando Halie e Dewis retornam para casa no Ato III, "Ela deixa escapar um riso estridente de embaraço por Padre Dewis", e desculpa-se para lidar com o marido e com o filho. Ela também se desculpa com Dewis pela situação que eles encontram. Quando 
ela percebe que Shelly está lá, Halie busca novamente, ostensivamente, por uma resposta "apropriada": "Padre, temos uma estranha na minha casa. O que você aconselharia? O que seria uma atitude cristã?" (p. 116) Quando Bradley usa a palavra "prostituta" no Ato III, Halie arrebata, "Olha o linguajar! Não vou tolerar esse linguajar na minha casa!" (p. 120). O projeto pessoal de Halie do começo ao fim da peça é arranjar um memorial para Ansel, uma estatua "Inteira de bronze. Da cabeça aos pés. Uma bola de basquete numa das mãos e um rifle na outra", o exemplo mais perfeito em manter as aparências (p. 116).

A preocupação de Halie com as convenções sociais frequentemente toma uma forma religiosa e dogmatica: o possível cristianismo ao tomar a pílula, a apropriada resposta cristã para a estranha na casa. Ela culpa o Catolicismo, na pessoa da noiva de Ansel, pela morte do seu amado filho. Halie fala das rosas que ela traz no Ato III que "Elas quase cobrem o cheiro fétido do pecado nessa casa" (p. 116). A obsessão de Halie com religião e controle vem conjuntamente quando ela entra no Ato III: "Você não pode deixar essa casa por um segundo sem que o Diabo chegue inesperadamente pela porta da frente" (p. 114). A religião de Halie, entretanto, é mais uma questão de forma do que um apoio espiritual; o pastor dela é seu amante, com quem ela partilha uma noite e um frasco de uísque.

Enquanto Shepard não especifica uma denominação para Halie, seu ódio virulento contra o Catolicismo e Dewis ser chamado de Father implica que ela é Episcopal (desenvolveu-se da Igreja Anglicana), a fé da família de Shepard. A conexão denominacional, apesar de não ter um efeito pronunciado na peça, tem uma conexão com atitudes em relação ao álcool na cultura americana como um todo.

O tratamento de Halie por Shepard, assim como seu tratamento de Ella em Curse of the Starving Class é áspero. Ela e seu aliado Bradley são os personagens menos solidários numa casa cheia de personagens não solidários. Críticos frequentemente deduzem que Shepard é misógino e, portanto não está disposto, ou simplesmente é incapaz, de criar uma personagem feminina bem arredondada e solidária. Marranca, por exemplo, caracteriza seu tratamento de mulheres como 'opressivo' (1981, p. 22). A análise sistêmica da peça sugere outra razão; Vince é um dos outros substitutos examinadores de Shepard. Dada essa identificação autoral, podemos esperar que a visão que Shepard tem de Halie reflita aquela de muitos filhos de famílias alcoólatras: a facilitadora deve ser culpada pelos problemas familiares e consequentemente torna-se o repositório de desapontamento e fúria (DEUTSCH, 1982, p. 36).

A chamada "hipótese de personalidade perturbada" afirmou que "esposas de alcoólatras eram mulheres perturbadas que procuravam por homens que elas pudessem dominar" (METZGER, 1988, p. 225). Em outras palavras, a patologia da esposa foi causa ao invés de efeito. O retrato feito por Shepard de Ella e Halie sugere que sua visão sobre o personagem é similar.

A reposta dos críticos aos retratos dessas mulheres feitos por Shepard observou sua visão negativa delas. Falk, por exemplo, atribui a essas mulheres, que Shepard criou, o termo: "ladras de almas" e observa que "Tanto Ella quanto Halie são um tipo de mãe/esposa/prostituta... Essas mulheres consentem em legalizar a fantasia masculina de deslealdade feminina que os homens sentem que eles estão totalmente certos em temer" (1981, p. 100). Rudolph Erben (1987, p. 37) não somente concorda com a imagem 
negativa dessas mulheres, como também culpa Ella, Halie e Lorraine (em A Lie of the Mind) pela destruição familiar. Ele diz:

\begin{abstract}
As mulheres nas peças familiares de Shepard são incapazes de compreender que família é uma "coisa animal", muito mais que uma "coisa social". Elas pertencem ao mundo exterior que destrói a família juntamente com o indivíduo... Buscando ganhos financeiros e dispondo-se a pagar por eles, mulheres na família desempenham um papel fortemente conectado com "outros homens".
\end{abstract}

Um dos "outros homens" a quem Erben refere-se é Padre Dewis, um personagem que ilustra o papel familiar estendido a um estranho. É mostrado como fraco, covarde, imoral e incapaz de ajudar a família em suas necessidades mostrando que a religião não tem respostas para os problemas dos homens.

O padre Dewis é um exemplo do facilitador profissional, o suposto conselheiro que encoraja o status quo doentio com uma cegueira obstinada e banalidades. Wegscheider define este papel familiar extra como: "Qualquer conselheiro ou outro profissional de ajuda que engajar-se em... negação, revogação, acobertar, proteção, assumir responsabilidade por outras pessoas, tanto o dependente ou qualquer outro membro familiar..." (p. 221). Dewis não assume responsabilidade por ninguém, mas é adepto da negação, revogação e acoberta fatos. Dewis diz para Shelly: "Não existe nada o que temer. Estas são todas boas pessoas. Todas essas pessoas são honradas" (p. 121). Ele também afirma que "estas pessoas querem ser deixadas em paz" (p. 122) e que ele "não tinha ideia nenhuma que havia qualquer tipo de problema. Nenhuma ideia mesmo" ( $p$. 131). Como ele afirma que viu o falecido Ansel jogar basquete, Padre Dewis esteve por perto mais do que o suficiente para que suas afirmações pareçam irônicas para nós.

\title{
3.2.6 Ansel: o herói familiar
}

Como observamos no Ato I, os filhos nessas famílias decidem assumir papéis rígidos. Os filhos de Dodge e Halie fornecem retratos vívidos desses papéis conduzidos até a idade adulta. A narrativa de Halie sobre Ansel o consagra como o herói familiar, um papel geralmente ocupado pelo filho mais velho. Halie, entretanto, narra sobre a posição de Ansel: "Eu sempre pensei que [Tilden seria] o filho que assumiria a responsabilidade... Então quando Tilden tornou-se um grande problema, joguei todas as minhas esperanças em Ansel" (p. 72). Responsabilidade e esperança são precisamente o que a criança herói representa para essa família. Wegscheider (1981, p. 104) descreve a contribuição do herói:

O herói é útil dentro do círculo familiar e bem sucedido fora dele. Ele propicia aqueles momentos de esperança e orgulho que até mesmo as famílias mais desesperadas experenciam de vez em quando, proporcionando uma fonte de valor para família quando todas as outras fontes secaram.

Halie quer dar forma material ao sentido de valor que ele propicia quando decide "edificar uma placa para Ansel" (p. 73). De acordo com Halie, Ansel "era um herói... Um herói genuíno. Corajoso. Forte. E muito inteligente" (p. 73). Ele também era um soldado que "poderia ter sido condecorado por valor" (p. 73). 
Halie acredita que, se Ansel estivesse vivo, ele teria tomado conta dos seus irmãos e dos seus pais, ele poderia ter ganhado "montões de dinheiro" (p. 73). "Lógico que quando Ansel morreu", ela diz, "aquilo nos fez ficar completamente sozinhos. O mesmo que ser deixado sozinho. Nenhuma diferença. O mesmo que se todos eles tivessem morrido" (p.73).

\subsubsection{Tilden e sua identificação com Dodge}

Tilden foi útil ao sistema quando se meteu em problemas. Apesar de que quando o encontramos na peça, ele é arredio, infantil, e dependente, ele claramente passou a maior parte da vida dele agindo com uma ira frustrada da família.

Tilden faz sua contribuição para família ao adotar e expressar a raiva, o desapontamento e a frustração de cada membro familiar. Qualquer criança pode aprender a interpretar esse papel. Por exemplo, se o relacionamento entre os cônjuges já é dominado pela fúria, patente ou reprimida, quando a primeira criança nasce, a criança pode ser adestrada para interpretar aquele papel.

O papel autodestrutivo interpretado por Tilden, que se comporta mal e irresponsavelmente, desperdiça tempo quando deveria estar trabalhando, mete-se em problemas e traz desgraça. Ele também tem tendência a retirar-se precipitadamente sendo arredio ou fugindo, mas se ele for típico, ele volta-se para outra rota de fuga produtos químicos. Como podemos ver e ouvir na peça a escolha de Tilden é o álcool.

A primeira referência a Tilden em Buried Child não é o papel que ele está interpretando, mas a sua incapacidade: "DODGE: Tilden não consegue nem proteger a ele mesmo" (p. 68). A primeira ação de Tilden, entretanto inocentemente intencionada, o coloca em problemas. Porque ele traz o milho para casa, Dodge e Halie presumem que existe ou existirá, algum tipo de problema. Pois eles não plantam milho "lá trás na propriedade" desde "1935", Tilden não pode ter obtido o milho honrosamente. Dodge diz: "Eu não tenho problemas com vizinhos há mais de 57 anos. Eu nem mesmo sei quem são os vizinhos! E nem quero saber! Agora vá colocar esse milho de onde ele veio" (p. 70). Quando Tilden responde jogando o milho no colo de Dodge, o velho pergunta, "Você está com algum problema, Tilden? Você está com algum tipo de problema?" (p. 70). A negação de Tilden para essa pergunta faz com que Dodge mencione "um pequeno problema lá em Novo México" que nunca é explicado, mas é mencionado mais tarde por Tilden: "Eu não roubei [o milho]. Eu não quero ser expulso de Illinois. Eu fui expulso do Novo México e não quero ser expulso de Illinois" (p. 76). No Ato III, Dodge também diz para Shelly que Tilden, "foi para o oeste e meteu-se em problemas. Meteuse em problemas sérios. Não queremos nada disso por aqui” (p. 113).

O problema de Tilden no Novo México é o que o trouxe recentemente para casa, mas não é o único problema que ele teve. Halie relembra velhas histórias: "Tilden meteu-se em todo aquele problema. Não se precisa de cérebro para ir para cadeia" (p. 73). Halie inflexivelmente insiste que Tilden não pode ter permissão de "beber nada", nem ser deixado sozinho, especialmente "lá no terreno atrás da casa". "Precisamos vigiá-lo agora como costumávamos fazer antigamente. Do jeito que sempre fizemos. Ele ainda é uma criança" (p. 77). Quando ela retorna no Ato III, Halie reage a ausência de Tilden: "Dodge! (ela o chuta) Eu disse para você não tirar os olhos de Tilden! Onde ele foi?" (p. 
119) Apesar de Dodge dizer para Tilden que "Você não deveria precisar dos seus pais na sua idade. Isso não é natural", ele não obstante tenta monitorar o paradeiro de Tilden (p. 78). No Ato III, ele diz para Shelly, "Não podemos nos dar ao luxo de deixá-lo sozinho. Não agora" (p. 113).

A conduta de Tilden e sua narrativa sobre si mesmo também salientam seu papel, mas na peça ele é sincero e solidário na maior parte do tempo. No Ato I, por exemplo, ele repetidamente assegura a Dodge que ele ficará em casa com ele, mas assim que o seu pai adormece, Tilden pega a garrafa escondida e sai para beber. (p. 79 -81). A narrativa de Tilden sobre dirigir quando ele era uma "criança", sugere que o fato dele correr riscos e escapar da família está também associado com a construção desse personagem: "Eu dirigia o dia todo algumas vezes. Através do deserto. Longe de outros lugares ou prédios no deserto. Eu dirigia passando pelas cidades. Qualquer lugar. Passava pelas palmeiras. Relâmpago. Qualquer coisa...” (p. 102).

A relação de Tilden com Dodge é uma indicação adicional do papel que ele está interpretando. O forte laço de identificação entre o pai e Tilden que é do mesmo sexo, tem um número de elementos. Eles são: alguém para culpar por tudo que está saindo errado, e, portanto um escudo para parte da ira familiar que seria de outra maneira direcionada ao próprio Dodge; um foco alternativo para a conduta controladora de Halie, e um aliado e uma cópia exata dele. Isto não significa, entretanto, que o relacionamento entre o pai Dodge e Tilden é necessariamente agradável. Sempre acontece que os relacionamentos deles são nada além de raiva, culpa, e amargor. Em outros casos o pai ou a mãe pode liderar o caminho para o perdão e a compreensão assumindo um pedestal nos olhos infantis de Tilden e realçando a força de identificação. Dodge e Tilden parecem existir, ou permutar entre esses dois extremos.

Pai e filho comportam-se conspiradoramente para proteção mútua unindo-se contra Halie:

\footnotetext{
A VOZ DE HALIE: O que o Tilden está fazendo? DODGE: (para TILDEN) Não dê uma resposta para ela. TILDEN: (para DODGE) Não estou fazendo nada errado. DODGE: Eu sei que você não está.

A VOZ DE HALIE: O que ele está fazendo ai embaixo? DODGE: (para Tilden) Não responda.

TILDEN: Não vou responder. (p. 72)
}

Dodge também defende Tilden quando Halie ameaça de chutá-lo para fora de casa: "Por que você teve que dizer aquilo para ele? Quem se importa onde ele pegou o milho? Por que você tinha que ir lá dizer aquilo para ele?" (p. 76). Halie enfatiza o relacionamento entre os homens quando ela insiste que Dodge seja o escolhido para dizer para Tilden "não ir lá fora na parte de trás da propriedade, nunca mais", dizendo: "Ele nunca me ouve Dodge. Ele nunca me ouviu no passado" (p. 77). Apesar dessas coisas, Dodge não oferece para Tilden nem conforto nem consolo por sua vida destruída. Quando Tilden confessa que, no Novo México, "Eu estava sozinho. Eu pensei que estava morto", Dodge responde, "Poderia ter estado. Para que você voltou para cá?" (p. 78). Muitos dos seus pedidos ou comandos para Tilden ficar na casa com ele parecem vir do medo de Dodge do que Tilden possa desenterrar, ou da frustração da sua própria incapacidade tanto da sua preocupação por Tilden: "Eu não preciso de nada! Mas posso precisar. 
Posso precisar de alguma coisa a qualquer momento. Qualquer segundo agora. Não posso ser deixado sozinho por um minuto!” (p. 79).

As linhas de identificação que amarram Dodge e Tilden vão além da conduta presente deles. Dodge refere-se a ele mesmo mais de uma vez com um cadáver, um homem já morto. Como foi mencionado acima Tilden refere-se a ele mesmo similarmente no Novo México. Dodge afirma que Tilden "perdeu o juízo", Halie afirma que Dodge está "louco", (p. 118). A mais completa combinação dos dois, entretanto, vem da identificação do pai da criança assassinada; em algum momento na peça, cada um reivindica ou é acusado da paternidade do filho enterrado.

\subsubsection{O imaturo Bradley}

Bradley o filho mais jovem de Dodge e Halie é perverso, manipulador, infantil e valentão. Sua conduta é imatura enquanto a de Tilden é infantil. Bradley é o temporão e deficiente. Bradley agrupa ambas as condições. Na família ele é um objeto frágil que precisa da sua proteção, aquele que é visto como (e mantido) imaturo. Ele quer ser protegido de todos os tipos de coisas, mas mais importante da verdade; pessoas não somente fracassam ao tentar explicar para ele o que está se passando; elas conscientemente retêm informação e até podem dizer coisas para ele que são incorretas ou enganadoras.

Apesar da imaturidade de Bradley ser salientada no Ato II, como Shepard o descreve, Bradley precisa mover-se somente para ser irritante: "Ele move-se mancando exageradamente e quase mecanicamente. $\mathrm{O}$ ranger do couro e do metal acompanham seu caminhar vindos da armadura e das dobradiças da perna falsa" (p. 82). A primeira ação de Bradley na peça é raspar a cabeça de seu pai quando ele está dormindo.

O Bradley adulto é totalmente desdenhoso do seu pai e irmão. Seguindo sua entrada no Ato II, Bradley primeiramente aterroriza Tilden com questões sobre Shelley e então sugere que Dodge seja afogado. Shelly diz para Bradley: "Cale a boca!", e ele responde:

\footnotetext{
Opa lá! Senhorita. Não fale comigo desse jeito. Não fale comigo naquele tom de voz. Existiu um tempo quando eu tinha que aceitar aquele tom de voz de praticamente todo mundo. (apontando para Dodge) Ele, era um! Ele e aquele meio cérebro que acabou de sair daqui. Eles não falam comigo daquele jeito agora. Não mais. Tudo mudou agora. Círculo completo. Não é engraçado? (p. 106)
}

Para provar seu poder, Bradley molesta Shelly forçando-a a ficar parada de pé com a boca aberta enquanto ele enfia os dedos em sua boca.

Seja qual for o poder que Bradley tem, ou sente que tem, evapora na presença de sua mãe no Ato III. Ele acorda quando Halie puxa o cobertor e o joga para Dodge e Bradley grita: "Me dê o cobertor! Devolva-me o cobertor! Aquele é o meu cobertor!... Eu quero meu cobertor de volta! Dê-me o cobertor!" Halie o silencia com, "Cale a boca, Bradley! Agora mesmo! Já aguentei demais!" a respeito de que "(BRADLEY vagarosamente recua, deita-se no sofá, volta sua cabeça na direção de HALIE e choraminga suavemente)" (p. 115). Bradley interrompe seu estado de mau humor somente para comentar que Ansel "nunca jogou basquete", e Halie responde "Cale a boca, Bradley!" (p. 116). 
A acusação de Shelly de que Bradley enfiou sua mão na boca dela provoca a seguinte troca:

HALIE: Bradley! Você enfiou sua mão na boca dela? Estou envergonhada pelo que você fez. Não posso deixá-lo sozinho nem por um minuto!

BRADLEY: Eu nunca fiz isso. Ela está mentindo! ...Eu nunca fiz nada, mamãe! Eu nunca a toquei! Ela me assediou! E eu a recusei. Eu a recusei sem rodeios! (p. 120)

Quando Halie menciona que vai chamar a policia para livrar-se de Shelly, Bradley entra em pânico: "Não! Não traga a policia aqui. Não queremos a policia aqui. Esta é a nossa casa" (p. 122). Seus protestos subsequentes de inocência familiar refletem o papel de expressar completamente a desilusão familiar. Frente às intenções "detetivescas" de Shelly, Bradley edifica uma parede de respeitabilidade:

Não estou dizendo nada para ela! Nada está errado aqui! Nada esteve errado aqui! Tudo está do jeito que deveria estar! Nada jamais aconteceu de ruim! Tudo está bem aqui! Somos todas boas pessoas. (p. 122)

Bradley não acredita no que ele está dizendo mais do que o resto dos personagens acredita, mas dizê-lo é sua tarefa, parte do seu papel.

Os papéis que Bradley e Tilden continuam a interpretar mantêm o sistema familiar equilibrado. $\mathrm{O}$ relacionamento deles com seus pais e a resposta auto relatada de Halie em relação ao casamento de Ansel revelam a falta de crescimento apropriado da família. Como a maioria das famílias esta está emperrada no meio da fase de desenvolvimento e Steinglass (1987, p. 46) descreve essa distorção na família:

Outra maneira de explicar isso é que ênfase é colocada num período curto de estabilidade na vida familiar, em detrimento de outras questões. Deste modo desafios para essa estabilidade (isto é, vida dentro de uma fase desenvolvimental) são interpretados primariamente como ameaças ao status quo; a possibilidade para crescimento inerente nesses desafios é ignorada. Como conseqüência, movimento numa transição desenvolvimental é frustrado, e a fase desenvolvimental atual da família é estendida muito além da sua vida natural. Essa impressão é que a família está congelada no tempo; as implicações desenvolvimentais são uma mudança de forma do ciclo de vida habitual.

\subsubsection{O papel de Vince}

Vince, o filho buscando pelo pai e pela família, é um dos caçadores de identidade de Shepard. Como é tão frequente o caso em Shepard, a busca pela identidade é a busca por um papel. No contexto de Buried Child, o papel deve servir ao sistema. Durante o curso da peça, Vince tenta vários papéis antes de tomar o lugar de Dodge no sofá. Ninguém na família o reconhece até que ele encontra o papel que se adapta o papel de que a família precisa para manter seu equilíbrio destrutivo.

Shelly explica a busca de Vince para Dodge: 
Eu quero dizer que Vince tem essa coisa sobre sua família agora. Imagino que seja algo novo para ele. Acho algo difícil de lidar com. Mas ele sente que é importante. Você sabe. Ele sente que quer conhecer todos vocês novamente. (p. 86)

Apesar de Dodge não reconhecer Vince e da sua busca frenética pela garrafa amedrontar Shelly, Vince insiste que eles fiquem, dizendo: "Ele perdeu o juízo ou algo parecido. Preciso tentar ajudá-lo" (p. 91). Vince realmente tenta ajudar, sugerindo que Dodge deite-se, que ele "relaxe por um tempo". Quando suas tentativas de cuidá-lo não funcionam, Vince tenta outra conduta. Nem Dodge nem Tilden, entretanto, reconhecem os truques de infância de Vince: dobrar o seu polegar atrás das suas juntas, tamborilando nos seus dentes, fazer seu umbigo falar. Aparentemente, a única maneira que Vince tem para conseguir uma resposta positiva é pegar uma garrafa para seu avô.

O acesso de bebedeira de Vince e sua tentativa de fugir sugerem que ele está experimentando com o novo papel. É durante sua escapada, nas faces dentro da face dele refletidas no espelho, que Vince encontra a ele mesmo e a sua família. Quando Vince descreve sua linhagem, é um eco da descrição que Dodge faz da sua herança: "Uma longa linha de cadáveres!” (p. 112).

Quando Vince retorna, violentamente bêbado, jogando garrafas contra casa é uma exigência do papel que ele assumirá; o papel que em breve estará vago. Halie não tem dúvidas sobre a identidade de Vince, mas ela lamenta a mudança nele: "Eu simplesmente não entendo. Ele era um menininho tão doce!” (p. 128). Dodge está certo agora da identidade de Vince e decide fazê-lo seu herdeiro: "A casa vai ficar com o meu neto, Vincent. Toda mobília, equipamento e parafernália que estiver dentro. Tudo que estiver pregado na parede ou descansando debaixo desse telhado" (p. 129). Vincent já havia recebido o legado não falado de Dodge, o seu papel.

Steinglass (1987, p. 93) explica uma das tarefas primárias da fase tardia das famílias: a transmissão da identidade familiar de uma geração para outra:

Uma boa metáfora para esse processo é a noção do legado familiar, um tipo de cápsula do tempo na qual a família coloca aqueles itens que, de forma condensada, mais claramente transmitem a essência da família no presente para as gerações futuras.

Nos momentos finais de Buried Child, Shepard cria uma imagem visual poderosa do legado familiar: o corpo de Dodge coberto de rosas no chão, Tilden carregando carinhosamente o cadáver enlameado da criança enquanto ele sobe as escadas, e Vince, bêbado e arredio, ocupando seu lugar no centro do 'tableau' (uma forma de teatro silencioso no qual um grupo de atores senta em certas posições para criar uma pintura de uma cena histórica). Como Halie diz do andar superior, "Talvez seja o sol (Sun) [filho (son)]" (p. 132).

\subsubsection{A Criança Enterrada}

Apesar de não se inserir nas responsabilidades dos papéis familiares analisados no presente estudo, um dos símbolos da peça exige uma atenção especial. A criança enterrada do título da peça de Shepard permanece o mais perturbador e intrigante mistério da peça. No Ato I, a família apresenta alusões implícitas de um segredo que 
não pode ser contado. Quando eles realmente o contam, nos Atos II e III, seus relatos são irreconciliáveis. Somando-se a isso, muito do que é dito na peça carrega um segundo ou terceiro significados na luz do segredo parcialmente revelado. $\mathrm{O}$ dramaturgo resolutamente recusa-se a resolver o mistério. Numa entrevista de 1984, Shepard diz "Acredito que seja um truque barato dar uma solução para as coisas. É uma completa mentira propiciar soluções" (LIPPMAN, 1984, p. 10).

Muitas das inconsistências ou incompatibilidades são explicadas num ensaio de Christopher Whiting (1988), Digging up Buried Child. Whiting compara as três versões rascunhadas da peça com a versão definitiva encenada e publicada para esclarecer algumas das confusões. Linhas das duas primeiras versões, na qual Dodge mata seu filho recém nascido, permanecem na versão final, complicando a 'verdade' da peça definitiva: a referência de Dodge a sua carne e sangue sendo enterrado no quintal, por exemplo. Linhas persistem da terceira versão na qual Bradley, então uma criança pequena, matou seu irmão e teve que ser acobertado por seus pais. Seu pânico no Ato III do texto final, quando a revelação está prestes a acontecer, é realçado na versão na qual Dodge tece um comentário que, se você vai dormir "Eles matarão suas crianças" (p. 93). Encontrar as fontes de algumas ambiguidades, entretanto, não resolve o problema de interpretar "o que realmente aconteceu".

O que é indiscutível é que o assassinato dessa criança é algo que não deve ser comentado, especialmente na frente de estranhos. Buried Child é um exemplo marcante sobre o grau do segredo - a inabilidade para falar sobre problemas - ao invés da sua severidade, que define o quão disfuncional a família pode se tornar e o quão severamente seus membros são prejudicados.

A primeira referência pública feita sobre a criança enterrada é de Dodge: "[Bradley] não é minha carne e sangue! Minha carne e sangue estão enterrados no quintal" (p. 75). Halie diz somente, "É o suficiente, Dodge. É mais que o suficiente" (p. 77). Depois que Halie sai, Tilden faz uma objeção: "Você não deveria ter tido isso para ela" (p. 77). No Ato II, é Tilden que revela e Dodge que reage. Não observado por Dodge, Tilden começa a contar a história para Shelley: "Tínhamos um bebê. (apontando para Dodge) Ele fez. Dodge fez. Podia pegá-lo com uma mão. Colocá-lo na outra. Um bebezinho. Dodge o matou" (p. 103). Quando Tilden continua, Dodge luta freneticamente para impedi-lo, mas Tilden continua falando e Dodge cai no chão tossindo. De acordo com Tilden, Dodge "disse que ele tinha suas razões. Disse que isso vinha de muito longe. Mas ele não contaria para ninguém” (p. 104).

A explicação de Dodge fornece uma razão, e provoca reações desesperadas tanto de Halie quanto de Bradley. Shelley estimula Dodge a revelar seu segredo. Ela diz, "Eu sei que você tem um segredo. Todos vocês têm um segredo. É tão secreto que todos vocês estão convencidos que ele nunca aconteceu" (p. 122). Quando ele ameaça contar para Shelley o que aconteceu, Halie diz, "Dodge, se você contar isso - se você contar isso, você estará morto para mim." (p. 123). Bradley, incapaz fisicamente de impedir Dodge porque Shelley está com sua perna, evoca o 'pacto' de segredo que a família fez, mas Dodge recusa-se a parar. A última palavra de Halie sobre o assunto invoca Ansel: "Ansel o teria impedido de dizer essas mentiras!" (p. 124).

$\mathrm{Na}$ versão de Dodge, ele matou a criança, ele a afogou, pois não era filho dele. Dodge afirma que "Halie engravidou novamente" quando "não estávamos dormindo na mesma 
cama por mais ou menos seis anos" (p. 123). Ele também diz que "Todos a nossa volta sabiam disso. Todos. Todos os nossos garotos sabiam. Tilden sabia" (p. 124). Dodge explica:

\begin{abstract}
Não podíamos permitir que algo como aquilo continuasse. Não podíamos permitir que aquilo crescesse bem no meio das nossas vidas. Aquilo fazia com que tudo que nós alcançamos parecesse nada. Tudo foi cancelado por esse único erro. Essa única fraqueza. (p. 124)
\end{abstract}

Na história de Dodge, o infanticídio era um tipo de expiação, um 'bode expiatório' definitivo, mas claramente o sacrifício não trouxe nenhuma redenção.

A interpretação crítica mais amplamente difundida desse mistério é que a criança que Dodge afogou era o resultado de uma relação incestuosa entre Halie e Tilden. Esse ponto de vista origina-se na referência de Tilden, "Eu tive um filho uma vez, mas nós o enterramos", e da afirmação de Dodge que "Tilden era o que sabia de tudo. Mais do que qualquer um de nós" (p. 124). Dodge também descreve o cuidado que Tilden tinha pela criança. A abordagem sobre o filho de Tilden é necessária para sustentar a interpretação que Vince e a criança enterrada são um e o mesmo, ambos são o filho sobre quem Tilden fala.

O presumido incesto, como aquele insinuado em Curse of the Starving Class, pode ser considerado como outra consequência da disfunção nessa família. A referência gráfica de Halie sobre beijar Ansel no dia do seu casamento pode também sugerir incesto e como consequência um padrão de desposar os filhos como substitutos de Dodge. Seja lá qual for a sua paternidade, a criança afogada permaneceu enterrada por um longo período e existem mais maneiras do que afogar e enterrar uma criança. Mottram (1988, p. 143) sugere uma interpretação desses atos:

Dodge recusa-se a ser um pai para os seus filhos, e como resultado um está exausto, o outro está mutilado, e o terceiro está morto. O misterioso quarto está enterrado no campo atrás da casa, enquanto Vince, o neto, está fadado a continuar uma linha de cadáveres, a imagem de um criador o qual o negou. A busca de Vince por um pai termina no túmulo de uma criança a qual, na verdade, não teve pai.

Dez anos depois de ter escrito Buried Child, ao falar sobre ser um pai para o seu próprio filho, Sam Shepard disse: "Porque eu nunca tive um pai no sentido de ele ter sido um 'pai' para mim, eu ainda estou experimentando em descobrir que papel é esse" (SESSUMS, 1988, p. 78).

\title{
3.2.11 Reflexões sobre Curse of the Starving Class e Buried Child
}

Como Curse of the Starving Class e Buried Child estão intimamente relacionadas faz-se necessário refletir sobre alguns aspectos antes de prosseguirmos com a análise de Fool for Love. Como Brookhouse (1988, p. 65) observa sobre as peças familiares: "Uma peça parece emergir da outra; os trabalhos são quase como uma única peça [...]". Rick Amidon (1986, p. 91) cataloga similaridades: "Estes lares não tem autoridade, orientação, liderança e experiência necessárias para que eles sejam moralmente, psicologicamente e financeiramente unidades saudáveis". 
A família de Buried Child pode muito bem ser a família de Weston; o problema de Tilden no Novo México pode ser o problema de Weston na Califórnia. Wesley e Vince incorporam buscas similares por identidade e comunidade - uma maneira de ser e um lugar ao qual pertencer. O que Patraka (1985) e Siegal (1995) observam sobre Buried Child é também verdadeiro para Curse of the Starving Class: "É o contexto para afirmação de Shepard que comunidade e o pertencer a algum lugar devem estar ligados a família e as raízes biológicas não importando o quão destrutivo elas possam ser ou quantas ciladas forem armadas para você nesses meios [...]" (p. 41).

Durante a sua carreira, a busca artística de Shepard permaneceu subjetiva, refletindo suas preocupações presentes baseando-se no seu próprio passado. Esse passado, incluindo o seu próprio crescimento como parte de uma família alcoólatra multigeracional, cria uma visão de sistemas familiares como 'ciladas' e 'destrutivos'. Como tantas outras crianças de tais famílias, Shepard parece não ver um fim para o ciclo e nenhuma maneira de escapar dos laços de hereditariedade e destino. Além disso, em Curse of the Starving Class e Buried Child, a preocupação de Shepard com as emoções 'míticas' amplia sua visão fatalística e prejudicial para todas as famílias, para algo inerente às espécies ou às suas instituições. Na entrevista concedida a Lippman (1984, p. 9) Shepard afirma:

\footnotetext{
Algo que é poderoso sobre um mito é a sua comunicação de emoções, ao mesmo tempo antiga e para todo tempo [...] emoções que não são somente emoções pessoais, nem somente emoções psicológicas que você consegue desabafar, mas emoções e sentimentos que estão conectados com todo mundo.
}

A visão de Shepard da origem de tais emoções muda ao longo do tempo. Sua aceitação das condições e atitudes provocadas por esses tipos de famílias aperfeiçoa-se. Como a sociedade em geral ele parece tornar-se cada vez mais cético da necessidade de aquiescer à tirania do sistema familiar.

A singularidade da superfície do método teatral de Shepard - mudanças que confundem, choques psíquicos, o simbolismo desconcertante, mergulhos não realistas e personagens que representam explosões de romance e paixões instintivas não padronizadas, características tradadas nas duas peças anteriores e que serão abordadas na análise da próxima peça a qual envolve duas gerações: o amor da segunda duplica o amor da primeira geração ou o carrega para uma nova dimensão e a ênfase está no presente ao invés de na influência ou recorrência (como nas peças anteriores). No próximo capítulo analisaremos uma peça na qual Sam Shepard faz várias perguntas, dentre as mais importantes: O que é o amor? O que significa ser um homem? Alguém pode escapar seu destino? Estas são perguntas que os protagonistas da peça, Eddie e May, estão se perguntando enquanto eles tentam viver a vida apesar de seus casos de amor tempestuosos e complexos e de suas próprias falhas.

\subsection{Fool for Love: Sam Shepard e a visão masculinizada da realidade}

\subsubsection{Fool for Love - uma paixão sadomasoquista}

"Uma mulher não é a resposta. Nunca foi.", Austin diz para Lee em True West (SHEPARD, 1980, p.44). Mas em Fool for Love, que estreou no Magic Theatre em 1983, Shepard tentou pela primeira vez criar um personagem feminino que seria 
absolutamente verdadeira para ela mesma, não somente como um ser social, mas também como um ser emocional. $\mathrm{O}$ foco de Shepard nessa peça foi o relacionamento masculino/feminino. May e Eddie formam um casal atormentado no centro da ação e são mais do que simplesmente amantes eles são meio irmãos, membros de uma família dupla representada no palco pelo The Old Man, um personagem que existe nas mentes de May e Eddie.

Fool for Love se passa num simples quarto de um motel barato próximo do deserto de Mojave. Shepard especifica que a peça "deve ser encenada implacavelmente sem um intervalo" e apesar do detalhe realista do cenário, o dramaturgo insiste na distorção dos efeitos sonoros e visuais. Assim que as luzes se acendem vemos The Old Man num canto do palco colocando uísque num copo de isopor. May está sentada encolhida na beira da cama. Eddie, um vaqueiro cujos jeans "cheiram a suor de cavalo", está trabalhando com seus apetrechos de rodeio. Eddie está tentando persuadir May a olhar para ele ou falar com ele. Quando ela fala é para acusá-lo de ter estado com outra mulher. O plano de May é matar Eddie e a Condessa (possível amante de Eddie com quem ele mantinha um relacionamento) com facas diferentes para que o sangue deles não se misture. Eddie está decidido a levar May de volta com ele para o trailer que ele está transportando para o Wyoming, mas May afirma detestar toda aquela porcaria, além de ressentir suas periódicas aparições e sumiços. Paradoxalmente, May pede que Eddie fique.

May entra no banheiro e The Old Man fala, pela primeira vez, com Eddie. Ele aponta para uma foto imaginária de Barbara Mandrell (cantora americana de música country famosa nas décadas de 70 e 80) com quem ele está casado em sua própria mente. May retorna e ao mudar de roupa diz a Eddie que um homem vai passar para buscá-la. Eddie pega sua arma e uma garrafa de tequila na caminhonete que está estacionada na frente do motel e bebendo ele conversa com ela sobre o relacionamento dos dois. Eddie afirma que May nunca irá substituí-lo e ela o expulsa do quarto. Quando ele sai, ela lamenta, chorando e segurando-se nas paredes do quarto, enquanto The Old Man conta para ela uma história da infância.

Eddie retorna, pois acredita que May inventou seu encontro e começa a cortejá-la tentando impressiona-la com suas habilidades com a corda. Enquanto eles discutem sobre ela ir embora com ele, os faróis brilham através da janela do quarto de motel. O carro do lado de fora, entretanto, não pertence ao suposto namorado de May. Eddie bate a porta da frente e apaga as luzes ao som de tiros e de vidro quebrando. Eddie protesta que não é a Condessa, mas insiste que as luzes permaneçam apagadas. May não se deixa intimidar e quando as luzes se acendem ela está de pé na porta. Eddie tenta impedi-la e os dois estão lutando quando Martin (um tipo de homem simples e inocente que mora numa cidade próxima do motel onde May está hospedada. Ele é um homem encorpado que trabalha com manutenção de lugares, como o estádio da escola da cidade) entra, interfere e está preste a bater em Eddie quando May o impede. Enquanto May vai e vem do banheiro Eddie ameaça Martin, mas o impede de sair. Eddie conta para Martin que ele e May não são primos, mas filhos do mesmo homem. Puxando o relutante Martin no palco, Eddie conta como ele e May se encontraram: "Mas no segundo que nós vimos um ao outro, naquele segundo, nós soubemos que nunca deixaríamos de nos amar" (p. 50). May, que ouviu a narrativa, repudia a versão de Eddie e termina a história sob os protestos do The Old Man. Eddie confirma a versão de May sobre o suicídio da mãe dele e quando os dois se unem, The Old Man tenta, fisicamente e verbalmente, ficar 
entre os dois. O beijo deles é interrompido por uma explosão fora do palco e pelo som dos cavalos de Eddie relinchando e galopando para longe. Quando Eddie sai dizendo que voltará em breve, May sabe que ele se foi. May pega sua mala e sai do palco enquanto o The Old Man termina o show apontando para a foto imaginária de Barbara Mandrell, dizendo: "Ela é toda minha. Para sempre." (p. 57).

Martin é um personagem bastante intrigante. Ele é o único aspecto do mundo exterior ao qual é permitido estar dentro do quarto de motel, ele é um constante lembrete para os outros personagens de que outro mundo realmente existe além daquele quarto de motel. Apesar de Martin ser originariamente utilizado como um peão tanto por Eddie com por May para causar dor um para o outro, eles rapidamente começam a competir por sua atenção:

\footnotetext{
Martin é obrigado a sentar e julgar mesmo não disposto sobre contos de May e Eddie do passado, como eles competem por sua credulidade e simpatia. Ele é a única testemunha terrena para as batalhas deles, ele possui o poder de verificar o passado, para decidir qual deles está vivendo uma mentira e qual a verdade, se alguma verdade existe em tudo. (DEROSE, 1986, p. 119)
}

De pretendente a juiz, a importância de Martin rapidamente muda quando ele é forçado a ouvir a saga que se revela perante ele sendo outro aspecto relevante que apresenta é a sua inocência. No meio dessa sórdida história, ele é uma representação da inocência que está perdida para os demais personagens.

Como nas outras peças familiares, os personagens contam versões inconciliáveis das mesmas histórias. Muitos dos críticos que escreveram sobre Fool for Love focam no contraste que Shepard faz do real e do imaginário. William Kleb (1983, p. 80), no seu comentário sobre a produção original, classifica Eddie e Martin como representantes dessas duas esferas e May como um ser preso entre dois mundos simbólicos: "Realidade (concreta, segura, estável, mas também desoladora, sórdida, vazia, morta) e Fantasia (perigosa, irreal, não confiável, auto-destrutiva, mas apaixonante, excitante, cheia de vida)". Ron Mottram (1984, p. 157), por outro lado considera May como uma representante da realidade em oposição a Eddie, que fantasia tudo: "May é o oposto; ela está livre de fantasias, uma realista capaz de manter um compromisso humano duradouro."

Para Shepard os relacionamentos masculino/feminino carregam emoções míticas. Em sua entrevista com Amy Lippman de 1984, ele disse: "Se, por exemplo, você olhar para Romeo e Julieta como um mito, os sentimentos com os quais você é confrontado numa peça como aquela são verdadeiros por muito tempo. Eles serão sempre verdade." (p. 9). Os amantes de Shepard podem ser mais sórdidos do que os de Shakespeare, mas não são menos obcecados e enquanto tais histórias podem não provocar comparações com a mitologia antiga, elas certamente são figuras proeminentes da cultura popular.

Steven Putzel, um critico que considera a relação do espectador com a peça, menciona as palavras do The Old Man para Eddie: "Aquilo é realismo. Eu na verdade sou casado com Barbara Mandrell na minha mente” (p. 27). Putzel (1987, p. 156) afirma:

Isso atua como um aviso para o público, permitindo que saibamos que existem diferentes planos de realidade, diferentes níveis de verdades e de mentiras, e que precisaremos expandir nossas expectativas além do realismo para podermos nos tornar cúmplices na representação. 
Para Ann Wilson (1988, p. 56) é The Old Man personificando o significativo domínio do Pai que domina a recepção da peça. Ela afirma:

Em Fool for Love o foco é na economia psíquica do espectador. O que é real é aquilo a que é dado uma imagem na mente. O real é caracterizado por sua capacidade de ser visualizado e então está dentro do domínio do Pai. May, apesar de mais complexa do que muitos outros personagens feminos anteriores de Shepard é produzida dentro de uma cena de representação a qual é determinada pelo masculino.

A análise de Lynda Hart também foca no pai, não como um representante do domínio da significação, mas como o autor da cena dolorosa e desesperada na qual Eddie e May parecem destinados a representar inúmeras vezes. No seu exame de Fool for Love como uma espécie de drama realista, Hart (1987, p. 104) escreve:

A ação da peça consiste na tentativa do jovem casal de escapar dos padrões psicológicos que thes são impostos por seus pais e seu esforço em resolver o dilema do relacionamento criado pela hipocrisia do pai deles.

Os comentários de Hart descrevem a dupla responsabilidade que The Old Man tem pela relação punitiva de May e Eddie: ele gerou ambos e eles estão seguindo um padrão que ele estabeleceu. O incesto, para William Kleb (1985, p. 81), é preocupante sendo que ele observa "que o que diferencia esses amantes da vasta maioria dos seus irmãos literários e dramáticos é a ausência de qualquer sentido de culpa". Podemos encontrar uma explicação para essa ausência de culpa no isolamento social do casal. William Kleb conclui que "O amor de May e Eddie parece moldado não pelo fato do seu parentesco, mas pela sua herança genética" e que "essa conexão é tão intensa que os dois são praticamente uma pessoa" (p.82). Rick Amidon (1986, p. 16)tem uma conclusão similar: "o fato que May é meia irmã de Eddie sugere que a atração dele por ela e para longe dela é gerada pela projeção ou imagem dele mesmo (e de seu pai) o qual ele vê em May".

\subsubsection{May x a Condessa e Eddie $x$ Martin: um relacionamento?}

A identificação de Shepard com os personagens masculinos está mais conectada com os dramas familiares anteriores nos quais Shepard marginaliza ou culpa os personagens femininos. Em Fool for Love, Eddie trata May como um objeto e ela participa da sua própria coisificação. A insistência de May em buscar a verdade, salienta não somente a determinação de Shepard em criar um personagem feminino viável, mas insinua um ceticismo nascente sobre a aceitação fatalista do futuro familiar determinado. Em Fool for Love, pela primeira vez nas peças familiares, os personagens desafiam, embora sem sucesso, o poder da ilusão.

Eddie é o fac-símile de seu pai e o vaqueiro prototípico: um peão de rodeio e dublê que chega na sua caminhonete puxando um trailer com cavalos. Suas idéias sobre masculinidade e sobre o relacionamento entre homens e mulheres confirma a imagem do "Malboro man" que May menciona. Quando May e Eddie discutem seu futuro encontro com Martin, May diz: "Anybody who doesn't half kill themselves falling off horses or jumping on steers is a twerp in your book." "That's right", Eddie responde. 
(p.30). Eddie vê Martim como um rival num tipo de competição: "I'll let you be the judge", ele diz para May (p. 30). Aparentemente ela parece ser o premio também.

Florence Falk (1981, p. 95) faz uma observação sobre homens e mulheres nas peças de Shepard:

Para serem bem sucedidos, os personagens do sexo masculino brincam de ser Homens, e seus personagens do sexo feminino de ser Mulheres; ambos os sexos representam não necessariamente o que homens e mulheres são, mas como eles imaginam que Homens e Mulheres se comportam.

Na sua fala inicial, Eddie trata May gentilmente, mas durante o resto da peça a atitude dele em relação a ela é insensível como se ela fosse sua propriedade. Assim, como The Old Man culpa a mãe de May por sua bigamia, Eddie culpa May pela recente separação deles: "What'd you have to go and run off for anyway?" Ele acredita que May deveria ter suportado sua prolongada ausência, pois ele menciona: "I bought you a whole stack of those fashion magazines before I left. I thought you liked those. Those French kind." (p. 26). Ele a desafia quando ela afirma que está trabalhando como cozinheira: "A cook? You can't even flip na egg, can you?" (p. 25). Ao inves de perguntar a May o que ela tenciona fazer, Eddie diz a ela: "I'm taking you back, May" (p. 24). Ele insiste que May vá com ele para o Wyoming para viver com cavalos, galinhas, e cuidar da horta e quando ela diz para ele: "It makes me puke to even think about it" (p. 25). No mundo de Eddie, homens agem e as mulheres apreciam, ou ao menos aceitam. Eddie também menciona suas idéias sobre relacionamentos masculino/feminino para Martin, que ao chegar menciona que não decidiu que filme ele e May irão assistir. Eddie declara:

O que significa que você não pode decidir? Você deveria ter tudo o que deu certo antes do tempo não é mesmo'? [...] Então você escolhe o filme, certo? O cara escolhe o filme. O cara é sempre quem supostamente escolhe o filme. (p. 45).

A ideia de May sobre o que é normal é menos proscrita do que a de Eddie. Martin, o namorado comum e o quarto de motel que ela chama de lar, a vida de May é certamente desoladora, mas ela diz para Eddie: "I got a job. I'm a regular citizen here now." (p. 24). May aceita os padrões da sua mãe, estereótipos culturais de gênero. Ela se veste para o encontro com Martin, assim como Shepard a descreve, "she gradually transforms from her former tough drabness into a very sexy woman" (p. 27). Esta May é a filha de uma "real pretty woman with red hair" que Eddie descreve para Martin. Quando ela se lamentava, a mãe "would pull herself up into a ball and just stare at the floor". (p. 53); a filha "sits on the edge of the bed facing audience... head hanging forward, face staring at floor" (p. 20). O relacionamento de Eddie e May é a cópia fiel dos relacionamentos de suas mães com The Old Man. Norwood (1985, p. 63) escreve sobre imagens culturais de amor romântico:

Sofrer por amor e ser viciado em um relacionamento são romantizados pela nossa cultura. Das canções populares a ópera; da literatura clássica aos romances; das novelas diárias aos filmes e peças, estamos rodeados de inúmeros exemplos de relacionamentos imaturos e não recompensadores que são glorificados e glamourizados. Repetidamente somos instruídos por esses modelos culturais que a profundidade do amor pode ser medida pela dor que ele causa e aqueles que verdadeiramente sofrem, verdadeiramente amam... Aceitamos que sofrimento é uma parte natural do amor e que a vontade de sofrer por amor é um traço positivo mais do que negativo. 
Para May e Eddie sofrer por amor é uma constante. Moldado por necessidade obsessiva, ciúmes e violência, o padrão destrutivo do relacionamento de May e Eddie faz com que qualquer relacionamento positivo entre eles seja impossível, assim como ele liga o casal indissociavelmente juntos. Talvez o que aparente ser lealdade é o medo do abandono e da mudança. May reconhece a conexão emocional dos dois:

Você não pode ficar me levando por aí. Tem sido assim por muito tempo. Eu não posso aguentar mais. Eu fico doente cada vez que você volta. Então eu fico doente quando você parte. Você é como uma doença para mim. Além disso, você não tem direito de ter ciúmes de mim depois de todas as besteiras que eu passei com você. (p. 30)

A visão de Eddie assim como a de seu pai é romântica e egocêntrica. Eddie acredita que o relacionamento deles estava fadado a acontecer: "It was like we knew each other from somewhere but we couldn't place where [...]" (p. 50). Desta vez, Eddie dirigiu "two thousand, four hundred and eighty miles" porque ele sentiu saudades de May: "more than anything I ever missed in my whole life" (p. 23). Para Eddie, o relacionamento é possessão assim como cuidar da pessoa amada. Seu propósito não é ver May, mas tê-la: "I came here to get you! Whatsa' matter with you! I came all this way to get you! Do you think I'd do that if I didn't love you!" (p. 39). Quando May protesta que Eddie a abandonará novamente, Eddie declara: 'I'm not lettin' go of you this time, May[...] I'm gonna take care of you, May. I am. I'm gonna stick with you no matter what. I promise"

Eddie parece genuinamente acreditar que May repetirá o padrão familiar das mães na peça, que não importa o quão frequente ou o quão longo período ele abandonar May, ela permanecerá conectada a ele e disponível. Sua resposta desproporcionada ao anúncio de May sobre o seu encontro com Martin mostra que Eddie sente certa insegurança:

EDDIE: Você está vendo alguém?

MAY: Quando foi a última vez que estivemos juntos, Eddie? Huh? Você consegue se lembrar tanto tempo atrás?

EDDIE: Com quem você está saindo?

MAY: Não me toque! Nem se atrevaa pensar.

EDDIE: A quanto tempo você está saindo com ele? (SHEPARD, 1984, p. 28)

Após essas falas, sentindo-se fortalecido com sua arma e garrafa de tequila, Eddie decide que pode neutralizar qualquer ameaça que o 'homem' represente: "You'll never replace me and you know it!” (p. 31). A declaração mais enfática de Eddie vem logo após a Condessa marcar sua presença:

Eu não estou indo embora. Eu não me importo mais com o que você pensa. Eu não me importo o que você sente. Nada mais daquilo importa. Eu não estou indo embora. Eu vou ficar aqui mesmo. Eu não me importo se uma centena de "rapazes" entrar por aquela porta - Eu vou pegar cada um deles. Eu não me importo se você me odeia. Eu não me importo se você não pode suportar a minha visão ou o meu som ou o meu cheiro. Eu nunca irei embora. Você nunca vai se livrar de mim. Você nunca vai escapar de mim. Eu vou encontrá-la, não importa aonde você vá. Eu sei exatamente como sua mente funciona. Eu estava certo todas as vezes. Cada vez. (p. 40)

Caracterizar May como vítima passiva de Eddie seria simplificar e negligenciar sua conduta. As tentativas da personagem em desafiar o sistema familiar apontam para uma nova direção do trabalho de Shepard. Tentaremos examinar suas inconsistências e ambiguidades. 
Antes mesmo de a personagem dizer uma palavra, Shepard estabelece rápidas mudanças. May agarra as pernas de Eddie e enterra sua cabeça no meio delas. Um momento depois ela bate nele com seus punhos (p. 21) Quando ele sugere que vai partir, May pede a ele que espere e no meio de um abraço ela o olha direto nos olhos e com tremenda força o ajoelha enterrando seu rosto em sua virilha (p. 26). Ela ordena que Eddie parta, diz a ele que o odeia e recusa-se a ir com ele, mas cada vez que ele deixa o palco ela fica devastada. A tristeza de May é inarticulada; ela a expressa ao abraçar as paredes do quarto, arrastando-se para cama, abraçando o travesseiro (p. 32 - 33). Numa das suas falas ela descreve a duplicidade dos seus sentimentos: "Fifteen years I've been a yo-yo for you. I've never been split. I've never been two ways about you. I've either loved you or not loved you. And now I just plain don't love you [...]" (p. 41)

May declara seu ódio por Eddie: "I don't understand how I could hate you so much after so much time", ao dizer isso a imagem da Condessa e Eddie vem a sua mente. Os impulsos de ciúmes de May são tão violentos quanto os de Eddie:

Eu vou matá-la e então eu vou matar você. Sistematicamente. Com facas afiadas. Duas facas separadas. Um para ela e uma especial para você... Assim, o sangue não se mistura. Eu vou torturá-la primeiro. (p. 23)

Seja qual for a ligação que Eddie e a Condessa possam ter, May fará de tudo para que não seja uma ligação de sangue, como a que une ela e Eddie. Parada na soleira da porta após o disparo que quebra o para brisas da caminhonete de Eddie, May ameaça e desafia a Condessa: "I'm gonna go out there. I'm gonna go out there and tear her damned head off! I'm gonna wipe her out!” (p. 41)

Apesar da insistência em falar sobre a verdade do seu passado, May assim como Eddie, utiliza a mentira e a negação para proteger a si mesma. Sua adulteração da verdade sobre Eddie para beneficiar Martin poupa todos do embaraço, mas quando May mente para Eddie ou ele para ela não nos leva a lugar algum. Eddie é um mentiroso perfeito; ele mente para May sobre a Condessa, ele mente para Martin sobre sobre o fato de que ele e May estavam bebendo e quando May desafia Eddie sobre sua versão do encontro que os dois tiveram "He told me that story a thousand times and it always changes," Eddie diz, "I never repeat myself" (p. 51). Poucos minutos antes, Eddie disse para Martin que inventar histórias não é mentir: 'No, no. Lying's when you believe it's true. If you already know it's a lie, then it's not lying" (p.45)

Eddie é viciado em mentir, em May, em álcool e agitação. Ele é um dublê, um peão de rodeio com o objetivo na vida de sobreviver a cada crise. Ele sente a necessidade de uma emergência, uma carga de adrenalina para sentir-se vivo. Eddie parte no fim da peça para perseguir a Condessa: "Well, I can't just let her get away with that. What am I supposed to do?" (p. 56) Uma mulher que atira e ateia fogo numa caminhonete, além de soltar os cavalos certamente cria uma emergência, literalmente acende o fogo para que Eddie o apague. A verdade dita por May é muito pálida em contrapartida.

Eddie representa a realidade da identidade americana: ele tentou abraçar os princípios de um personagem nacional, adquirindo terra a qual ele pretendia cultivar para viver. Num esforço em convencer May a ficar com ele, ele 'pinta' um retrato familiar do personagem americano: 
Eu tenho um pedaço de chão no Wyoming. [...] May, eu tenho tudo certo. Eu estive pensando sobre isso há semanas. Eu vou mudar o trailer. Construir um pequeno curral para manter os cavalos. Ter uma horta grande. Talvez algumas galinhas. (SHEPARD, 1984, p. 24-25).

O vestuário de Eddie reflete suas aspirações, como sua maneira de vestir é a de um cowboy tradicional que reaparece nas peças de Shepard tais como Geography of a Horse Dreamer (1974), Suicide in B-Flat (1976), e The Sad Lamento of Pecos Bill on the Eve of Killing His Wife (1983). Mas Eddie também representa o lado escuro e ameaçador da identidade americana. As direções de palco fornecidas por Shepard em relação a aparição de Eddie oferecem um comentário significativo sobre a imagem desse 'personagem' americano que desapareceu gradualmente na sociedade americana. Eddie veste:

\footnotetext{
Botas de cowboy quebradas e enlameadas com fita na cor prata embrulhada em torno delas no dedo do pé e no peito do pé, bem-vestida, desbotada, calça jeans suja que cheira a suor de cavalo. Camisa marrom. Um par de esporas balançando de seu cinto. Quando ele anda, ele manca ligeiramente e dá a impressão de que ele raramente não está num cavalo. Há uma qualidade quebrada peculiar sobre seu corpo, em geral, como se ele envelheceu muito antes de seu tempo. Ele está se aproximando dos quarenta anos.(p. 20)
}

Eddie, um retrato da identidade americana 'quebrada' e remendada com fita adesiva, sugere a natureza patética dessa imagem e também indica que a realidade dessa imagem é mais falha do que a idealizada que é promovida e perpetuada pela história e cultura americanas. Ao contrário de Cody em Geography of a Horse Dreamer, que é heroicamente salvo por uma 'autêntica' visão do caráter americano na forma dos dois irmãos (cowboys) de Cody; a representação de Eddie da identidade americana contem a mesma autenticidade, mas também expõe suas fraquezas.

Eddie incorpora uma das fraquezas mais proeminentes do caráter americano: sua violência inerente. Sua conduta agressiva é manifestada em cada uma das suas ações frequentemente dominando o espaço do palco quando está falando com May. E intermitentemente durante a peça, Eddie "moves violently toward her" (p. 28). As reações defensivas de May estabelecem a personalidade ameaçadora de Eddie. A conduta dominadora de Eddie em relação a Martin novamente exemplifica seu temperamento violento: "nail his ass to the floor" (p. 35). Essa violência torna-se uma marca registrada do 'americano' nas obras de Shepard. Fool for Love não fornece ilusão de glória envolvendo a violência, pois a violência de Eddie parece meramente feia e mesquinha.

O retrato de Eddie do caráter nacional americano também revela o que Shepard acredita ser a inevitável consequência da busca por uma identidade nacional - o impulso escapista americano. Eddie abandonou May repetidas vezes no passado, fazendo com que ela lamentasse sua presença cada vez que ele retorna: "It'll be the same thing over and over again" ela diz. "We'll be together for a little while and then you'll be gone" ( $p$. 31) Shepard deixa claro que Eddie representou a cena de abertura da peça muitas vezes criando um padrão cíclico de tentativas de fuga fracassadas: "May, look. May? I'm not goin' anywhere. See? I'm right here. I'm not gone. Look." (p. 21). Eddie "just disappeared", May o relembra, toda vez que o desejo bateu (p.25). 
Eddie simultaneamente lida com três tragédias, ele tem uma identidade complexa por causa de seu relacionamento complicado com a família e suas amantes além de ser o filho de um pai distante (The Old Man), que levava uma vida dupla. Ele é o amante de uma mulher que é sua meia-irmã, o filho de uma mulher que amava tanto que se matou ao descobrir a traição do The Old Man. Seus relacionamentos confusos e dolorosos contribuem para a sua necessidade de ter o controle final de cada situação. Eddie instiga um jogo de poder, retornando a May, repetindo o ciclo de abandono e de dependência com ela.

Sua vida é caótica, especialmente agora que ele está tentando ter relações com a Condessa e May ao mesmo tempo. Sua necessidade de controle e ordem se manifesta em sua atitude machista de precisar ter poder sobre outras pessoas. Eddie transforma sua bagunça macro em um microcosmo de ordem na forma como ele tenta manter May, fazendo com que Martin fique confuso e com medo dele e seus ataques verbais. Eddie transforma seu sofrimento em uma muitas vezes cruel, maliciosa e manipuladora autocapacitação. Ele sente-se ameaçado pela ideia de May viver por conta própria, independente, sem ele. Apesar de ter começado um relacionamento com a Condessa, Eddie quer conservar os dois relacionamentos, mantendo uma porta aberta na sua relação com May, enquanto continua seu caso com a Condessa. Eddie é a cara metade de May . Eles têm uma atração magnética, um sentimento apaixonado de um para o outro que pode ser cheio de amor ou ódio um pelo outro. May será sempre uma parte de Eddie e ele sabe disso, mas é lidar com o fato de May, um espelho para seu eu não ser mais o certo para ele. Ele voltou para não ficar de May, como ele diz, mas para fazer uma última tentativa desesperada de tentar ficar com ela quando ele sabe em seu coração, que tudo mudou e que ele nunca pode ficar em um lugar por muito tempo.

Outra forma Eddie tenta controlar May é por difamá-la por ter um encontro com Martin. Eddie é um hipócrita e sem saber disso, ele insulta May e fica com ciúmes, embora ele tenha deixado May para ter um caso com outra mulher.

Eddie partilha várias características em comum com seu pai, The Old Man, e teme em ser semelhante a ele. The Old Man tem causado tanta dor para Eddie que ele inconscientemente repete alguns dos problemas do The Old Man, como beber muito e ter duas amantes. Eddie não vê o seu comportamento como abandono ou negligência. Ele tem vontade de viajar. Ele segue seus sonhos sempre e quer realizar sua fantasia, ele não vê o ponto de vista de May. Ele tem um sentimento, apaixonado por May, que o domina, mas não é poderoso o suficiente para fazê-lo ficar em um só lugar. Ele nunca vai enfraquecer, mas ele nunca vai ser suficiente para satisfazer a sua atenção.

Como seu pai Eddie lida com a dor tentando controlar as mulheres na sua vida. Controle é o que domina cada aspecto da vida de Eddie. Ele traz seus pertences para o quarto de motel de May com o intuito de ganhar controle sobre ele; ele fisicamente domina May e Martin e os faz escutar o seu ponto de vista e tentará qualquer tática disponível para fazer com que May faça o que ele quer:

Ambos Fool for Love e A Lie of the Mind [...] oferecem-nos um olhar para a identidade masculina, particularmente no que é afetada pela ausência do pai [...] Mais precisamente, estas duas peças exploraram como um relacionamento do filho com as mulheres é profundamente afetada por sua relação com o pai, de quem o filho tem um conceito derivado de identidade precária e violenta [...] Tanto Eddie de Fool for Love e Jake de A Lie of the Mind alternadamente abandonam e voltar para as mulheres em suas vidas, 
representando seu desejo em conflito por independência e sua absoluta necessidade de contato com uma mulher para consolidar sua auto-imagens. Assim, mesmo quando eles rejeitam a civilização das mulheres, eles se voltam para uma versão fantasiosa do feminino, ainda que a versão fantasia também escapa do controle deles. (MCDONOUGH, 1997, p. 58).

\subsubsection{The Old Man e a determinação do masculino na peça}

Ao contrário de Weston e de Dodge, The Old Man não é visto por seus filhos há anos. Ele é mais que uma lenda familiar ou um lugar no deserto. The Old Man é palpável nas mentes de May e Eddie, uma presença inernalizada e tão forte que Shepard o faz visível para os espectadores. Sua influência não pode ser nem ignorada nem evitada. A primeira interação entre Eddie e The Old Man estabelece a conexão entre o pai e seu facsimile além das condições de comunicação que predominam entre os dois; a verdade é o que The Old Man diz que é verdade até mesmo se isto signifique a negação dos seus sentidos:

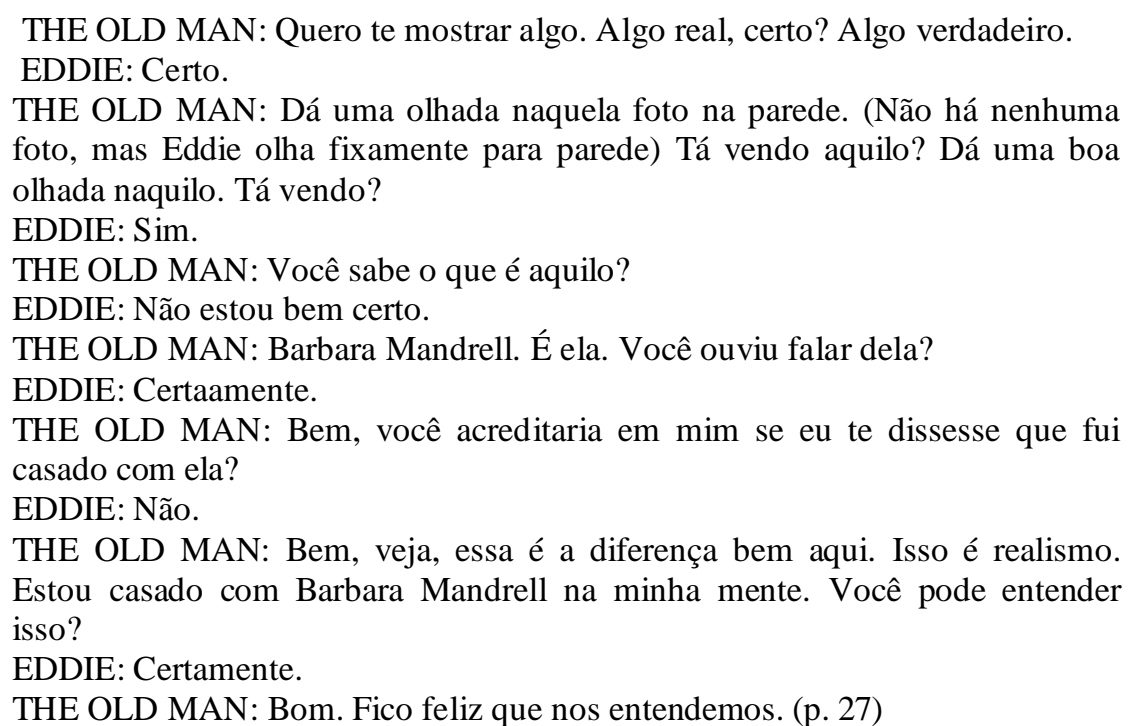

The Old Man insiste na sua versão das coisas. Quando as revelações se iniciam, Shepard intensifica a influência do The Old Man nos personagens ao permitir que o ator que o interpreta quebre a barreira física que o separa dos outros personagens durante a maior parte da peça. As mensagens internas que The Old Man representa são mais altas quando May e Eddie narram o passado deles. A primeira quebra dessa barreira é quando The Old Man partilha da garrafa de tequila de seu filho; quando Eddie se prepara para contar para Martin porque May está em estado de choque, The Old Man segura seu copo vazio e Eddie o enche. Enquanto Eddie conta para Martin que May é sua meia irmã e que eles estiveram juntos antes de saber disso, ele olha para The Old Man para verificação. Com o desenrolar da história, The Old Man comenta sobre a versão de Eddie sobre sua vida dupla, das duas mulheres pelas quais ele se apaixonou: "It was the same love. Just got split in two, that's all" (p. 48) Ele se defende: "Now don't be too hard on me, boy. It can happen to the best of us" (p. 48), mas ele questiona a veracidade de Eddie somente uma vez: "That was no Studebaker, that was a Plymouth. I never owned a goddam Studebaker". (p. 49)

A história de May provoca consternação ao invés de risadas no The Old Man. Ele repetidas vezes contesta a versão dela e incita Eddie a corrigi-la, movendo-se no palco 
pondo-se de pé entre eles. Quando Eddie confirma o relato de May sobre o suicido da mãe dele, The Old Man vira de um para o outro tentando resgatar sua própria explicação para reafirmar os mitos familiares que os personagens aceitaram anteriormente. Ele tenta, falando com May, transferir a responsabilidade para mãe dela: "But your mother-your mother wouldn't give it up, would she?" (p. 55). Quando não há uma resposta ele apela para Eddie, "Bring her around to our side. You gotta' make her see this thing in a clear light" (p. 54). A posição que The Old Man ocupa na psique de Eddie está resumida no apelo feito por ele:

Fique longe dela! Que diabos você está fazendo? Mantenha-se longe dela! Vocês dois não podem se unir! Você tem que segurar o meu fim esse é o trato. Não tenho ninguém agora! Ninguém! Você não pode me trair! Você tem que me representar agora! Você é meu filho! (p.55)

Alguns momentos antes The Old Man estava rindo sobre o fato de May e Eddie estarem 'fooling around'. Então não é a união física dos seus filhos que irá destruí-lo, mas a união dos dois traindo sua versão romantizada das coisas, da ilusão de sua inocência nos destinos de suas esposas e seus filhos.

The Old Man fala as últimas palavras da peça: "Ya' see that picture over there? Ya' see that/ Ya' know who that is? That's the woman of my dreams. That's who that is. And she's mine. She's alll mine. Forever.”(p. 57). Sua versão dos fatos prevalece. Quando May parte, sabendo que Eddie havia partido, ela reconhece o poder do The Old Man; seu domínio sobre eles é muito forte para ser quebrado por um momento de verdade. Assim como os filhos das peças familiares anteriores, Eddie rende-se, assimilando a replicação da vida do seu pai. A fala do The Old Man reforça a relatividade do "real" onde cada versão da história é real porque cada personagem acredita que ela seja. The Old Man constitue a imagem de uma mulher, Barbara Mandrell, como objeto de desejo. Os espectadores nessa peça são influenciados pela visão e mediação masculina do pai que também é The Old Man.

Doris Auerbach (1988, p. 59) fala sobre essa peça:

Eddie é tanto o filho que foi abandonado quanto o marido que a abandonou, incapaz de se livrar de sua obsessão com seu pai e seus laços sadomasoquistas com May, que é tanto a criança abandonada quanto a mulher.

The Old Man também serve como um constante lembrete do incesto em Fool for Love. A relação de sangue sobre determina a tendência dos filhos adultos de procurar e constituir relacionamentos com outros como eles mesmos, reproduzir em suas vidas adultas o mesmo sistema no qual eles cresceram. May e Eddie ligam-se não a parceiros de famílias similares, mas a um parceiro da mesma família. May e Eddie estão presos há anos nesta fase. Para que o relacionamento deles progrida da maneira como eles desejariam e necessitam, independentemente da reação deles ou nossa a noção de incesto, eles teriam que criar "a freestanding system". Steinglass (1987, p. 105) descreve o que isso implicará:

Se a nova família deve estabelecer sua própria integridade sistêmica, duas tarefas principais devem ser concluídas com êxito: (1) a família deve claramente delinear seus limites internos e externos, e (2) a família deve 
trabalhar para desenvolver um conjunto de crenças compartilhadas, valores e regras de comportamento para o qual seus membros podem referir-se.

May e Eddie permanecerão para sempre nessa fase inicial. The Old Man manisfesta a ultrapassagem dos limites externos; eles não podem ser um casal se são um trio. $\mathrm{O}$ sangue compartilhado de May e Eddie e sua obsessão recíproca ultrapassam os limites internos deles. Eles vêm um aos outros neles mesmos. "I can smell your thoughts before you even think "em," May diz para Eddie (p. 23) "I know exactly how your mind works. I've been right every time," Eddie diz para May (p. 40). Ao invest de desenvolver crenças compartilhadas, valores, e regras de conduta, May e Eddie repetem as dos pais; somente brevemente eles conseguem aceitar uma versão compartilhada do seu passado que contradiz o mito familiar.

Robin Norwood (1985, p. 102) afirma: "The more difficult it is to end a relationship that is bad for you, the more elements of the childhood struggle it contains". A relação de May e Eddie contém praticamente todos os elementos das lutas infantis dos dois. Eles repetem a revogação de responsabilidade; Eddie reprisa os abandonos do The Old Man enquanto May conspira para repetir a contribuição da mãe. May descreve a relação de sua mãe com The Old Man: "She was obsessed with him to the point where she couldn't stand being without him for even a second [...] she couldn't help herself" (p. 53). The Old Man descreve o relacionamento deles: "She kept opening her heart to me. How could I turn her down when she loved me like that? How could I turn away from her? We were completely whole" (p. 55). A descrição de May sobre Eddie e ela é similar:

Tudo o que eu conseguia pensar era nele. ... E tudo o que ele podia pensar era
em mim. Não é verdade, Eddie? Nós não poderíamos respirar sem pensar um
no outro. Não podíamos comer se não estivéssemos juntos. Nós não
conseguiamos dormir. Ficavamos doente à noite, quando estávamos
separados. Violentamente doente. (p. 54)

A semelhança de May com a mãe de Eddie é bem acentuada. Eddie menciona que sua mãe nunca deixou transparecer se ela suspeitava que algo estivesse errado sobre os desaparecimentos do The Old Man;

Talvez ela estivesse com medo de descobrir. Ou talvez ela simplesmente o amava. Eu não sei. Ele desaparecia por meses em um período e ela nunca lhe perguntou onde ele foi. Ela estava sempre feliz em vê-lo quando ele voltava. (p. 48)

May permitiu as idas e vindas de Eddie por quinze anos. Ela diz para ele: "How many times have you done this to me? [...] Suckered me into some dumb little fantasy and then dropped me like a hot rock. How many times has that happened?'(p. 25). Eddie não consegue negar o seu desaparecimento.

A aparente recusa de May em ser sugada novamente é minada por sua conduta: ela entra em pânico quando Eddie parece pronto para partir e lamenta-se quando ele parte; ela faz as malas sorrateiramente para estar pronta para partir com ele. A única tentativa real de May de desafiar o destino representado pelo The Old Man é sua determinação em dizer a verdade sobre a mãe dela e de Eddie: "I know the whole rest of the story, see [...] I know it just exactly the way it happened. Without any little tricks added onto it" (p. 52). Quando The Old Man partiu, a mãe de May "just turned herself inside out," lamentando "as though somebody'd died" (p. 53). "Blew her brains right out" (p. 54) A 
concordância de Eddie com a história de May destrói a ilusão do The Old Man que o fato dele ter partido não significava que ele estava desconectado: "There was nothing cut off in me. Everything went on just the same as though I'd never left" (p. 55).

Assim como True West, Fool for Love termina num impasse emocional. Eddie repudiou as mentiras, mas não a conduta de seu pai. Apesar de May ter reconhecido e dito a verdade, não consegue romper sua conexão com Eddie.

Surreal, engraçado, oferecendo um ponto de vista contrário, The Old Man só existe na mente de May e Eddie ainda que possamos vê-lo e ouvi-lo no palco sendo que sua presença contribui para a qualidade elevada de sonho da peça. Ele fala com Eddie e May, sobretudo, quando apenas um deles está no quarto de motel e o outro está fora ou no banheiro. Devido a isso, ele age como um público e uma resposta ao pensamento subconsciente de Eddie e May assim suas conversas com May e Eddie parecem ter lugar na paisagem de seus pensamentos e tornam-se real no palco. Por exemplo, ele fala de Eddie após ele ter sido enganado por May, quando ela o beija e depois o põe de joelhos com o rosto na sua virilha. Ele também fala com May, quando ela está chorando por Eddie e se movendo lentamente através das paredes da sala sozinha.

The Old Man faz companhia para eles quando estão sozinhos e ainda assim os assombra. Sua presença é um lembrete de seu passado complicado e da vergonha de sua relação incestuosa. Seu hábito de beber é repetida no consumo agressivo de May e Eddie e sua traição é repetida nos malabarismos pobre de Eddie em sua relação com May e com a Condessa. The Old Man oferece pontos de vista diferentes sobre o passado de May e Eddie e, na maior parte nega qualquer culpa na problemática atual deles. Ele chama Eddie "fantasista", talvez uma referência à atitude do pai, de Sam Shepard, na preparação para a função de seu filho como um dramaturgo que imagina as coisas para a vida e também como a característica de Eddie de ser um idealista que imagina um futuro melhor para si próprio onde é possível acreditar em suas próprias ilusões.

The Old Man acredita em ilusões de si mesmo e essa característica se repete em May e Eddie. Quando The Old Man era mais novo se convenceu de que poderia equilibrar duas vidas sem consequências. Agora, ele acredita que a mulher de seus sonhos inatingíveis, Barbara Mandrell uma imagem em sua imaginação, é sua esposa. Essa é a solução perfeita para ele, contentar-se com uma vida bastante ficcional que é agradável à imaginação e impossível de segurar por muito tempo.

May é lançada fora de guarda quando Eddie chega do nada e reacende todas as suas emoções e acaba cedendo para ele. Ela é loucamente apaixonada por Eddie mas é uma dor e amor, que se confundem e são consumidores. Seu amor por ele não se encaixa em sua vida e os problemas reais que ela deve enfrentar para sobreviver. May almeja estabilidade, afeto, auto-capacitação e independência. Eddie é contrário a qualquer desses desejos e, de fato, impede que eles existam na vida de May. Ela está dividida entre a fantasia e a memória de seu amor e a realidade da dor e da luta do dia-a-dia eles encontram-se juntos. Seu amor por Eddie domina May tão completamente que ele é como uma doença ou loucura. Ela não pode se concentrar em outra coisa senão nos dois e da forma que eles fizeram mal uns aos outros e quão forte atração eles sentem um pelo outro quando Eddie está ao redor. Quando Eddie parte, o vazio é tão grande que quase não vale o tempo que ele está presente. May se sente do mesmo modo como sua mãe 
sentiu sobre The Old Man. A mãe de May era tão apaixonada por ele que ela ficou extremamente deprimida quando ele se foi.

Eddie sente a necessidade de provar sua masculinidade para May durante toda a peça. Ele tenta ganhar May de volta, ao mesmo tempo mantendo vivo seu caso com a mulher que eles chamam de a condessa. Eddie mostra suas habilidades de rodeio para May laçando os pés da cama com sua corda. Ele é um egoísta que se torna ainda mais arrogante quando ele bebe. Eddie carrega em uma garrafa de tequila e uma espingarda em um ponto da peça. Tentando mostrar a May o quão forte é a sua tolerância, ele bebe muito da garrafa sozinho e ameaça May e seu amante misterioso que ainda não chegou. Ser um homem cheio de coragem, assumir riscos e ter uma forma única com as mulheres é o ideal de Eddie por isso ele espera que o amante de May seja nada além de "um punk idiota em um terno de dois dólares ou algo assim". Mesmo quando vê que Martin é inofensivo, ele continua a ameaçar e intimidá-lo. Eddie partilha muitos traços com o estereótipo do homem ocidental ou cowboy embora sua personalidade e passado façam dele um personagem mais complicado cuja profundidade e esforços vão além do arquétipo que ele coloca em um pedestal e rivaliza.

May e Eddie diferem em sua interpretação sobre seu relacionamento passado e presente. A forma como estes indivíduos se lembram do passado e da maneira que cada um interpreta esses eventos contribui para a formação de sua identidade. May se recusar a receber Eddie de volta porque ela não quer repetir os erros que sua mãe fez e os erros que ela mesma fez repetidamente. Ela também se sente envergonhada por sua relação de sangue com Eddie e quer deixar esses pensamentos para trás. Por outro lado, Eddie tenta conciliar os dois relacionamentos, um com May e outro com a Condessa, porque, como seu pai, ele não se vê como um errante, nem a identidade da traição como negativa. Ele não se perturba muito mais pela sua relação de sangue com May e ele vê os atos repetidos de abandono como falhas de May e não suas.

A capacidade relativa de May e Eddie para seguir em frente com suas vidas relaciona-se a interpretação de suas memórias. Seu doloroso e complicado passado afligem o seu presente com a versão da história que eles lembram ou acreditam. Suas memórias e o sentido da história define-os como indivíduos. Sua interpretação contraditória de suas memórias de seu passado compartilhado forma o colorido do seu presente conflito. Shepard parece estar dizendo que as memórias traumáticas dos indivíduos modelam cada pessoa de forma diferente e a tolerância de cada pessoa para a dor varia de indivíduo para indivíduo e nem sempre é compatível.

A imagem imaginária de Barbara Mandrell que The Old Man vê na parede invisível é real para ele, porque ele a vê em sua imaginação. Em sua mente, ele é casado com esta estrela country. Ele chama-a, "a mulher dos meus sonhos". Isso tem um duplo significado, em primeiro lugar, porque ela é uma estrela, então ela é uma figura romântica inatingível que é maior que a vida por causa de seu estrelato e segundo porque ela é inatingível através dos sentidos, porque ela está na mente do The Old Man. Ele descreve sua imagem como "realismo" vendo-o como a coisa que um indivíduo decide chamar realidade para si mesmo e na qual acredita, e mesmo se o que se acredita não é necessariamente baseado na realidade. Seu estranho senso de realidade permeia o sentimento da peça irrealista, assim como as emoções de seus personagens em mutação. 
A Mercedes Benz da Condessa nunca é vista no palco, mas imaginada através da descrição do personagem May, que a vê fora da porta do quarto de motel. May descreve o carro como uma "grande, grande, extralonga, preta, Mercedes Benz".May parece enfatizar o tamanho do carro, porque para ela é evidência sólida de que Eddie mentiu para ela sobre seu caso com a condessa. O carro é exagerado e chamativo, um objeto tangível que ostenta o novo relacionamento de Eddie na cara de May, além de ser símbolo do poder e status, coisas que May não possui. $\mathrm{O}$ carro destaca-se nos arredores da pequena e empoeirada cidade, no meio do nada onde May vive e representa um mundo, muito longe, glamuroso do qual ela não pode ser parte, mas ao qual Eddie já aderiu. O carro também representa o ciúme de May e do jeito que ela inflacionou seus sentimentos de ciúme. May diz que o carro se parece exatamente com o carro que ela sempre imaginou a Condessa dirigindo e tem-se a sensação de que May criou a chegada do carro em sua mente, não na realidade, como em um sonho ruim.

A peça termina com a imagem do fogo ardente do lado de fora da janela do motel quando Martin olha para fora e vê a cena da queima do carro de Eddie. A chama brilha em torno dos atores restantes no palco como um testemunho da paixão e pecados de May e Eddie. O fogo é similar ao seu relacionamento em que, quanto mais ele queima mais energia ele cria todo o tempo, destruindo a mesma coisa que o alimenta. May e Eddie também são pessoas mais potentes, mais, vivas e engajadas na presença um do outro, a sua paixão desperta seus sentimentos mais profundos, mas essa paixão é autodestrutiva.

Podemos afirmar que Eddie e May diferem em sua visão do sonho americano porque May e Eddie diferem em sua visão do passado. Eddie continuamente apresenta May com suas esperanças de realizar um sonho de viver juntos em seu trailer. May tentou esta vida e nunca supriu as expectativas de Eddie. May vê a dura realidade dentro da fantasia do sonho de Eddie. Ela prefere trabalhar duro, levar uma vida honesta, e provar a sua independência. May preferiria ter alguém ao seu lado em quem ela pudesse confiar vai ficar com ela do que ter Eddie parte do tempo. Seu sonho é mais concreto e impulsionado pela realidade enquanto Eddie, que acredita na fantasia que ele pode ter de May e a Condessa, ao mesmo tempo quer acreditar que se May e Eddie apenas seguissem o seu sonho, tudo funcionaria bem. Eddie deixou May sozinha na última vez que viveu com ele no trailer. Eddie vê o sonho da agricultura subsistente como uma maneira satisfatória para provar sua masculinidade sendo o provedor de May. No entanto, sua fantasia é simplesmente isso, ele não seria realmente feliz vivendo sozinho com May no campo.

May e Eddie vêem seu passado a partir de diferentes pontos de vista. May vê a história de seu passado de forma diferente da de Eddie, pois sua mãe era a pessoa que The Old Man estava traindo com a mãe de Eddie, sendo que sua mãe era o segredo que sempre foi deixado para trás. Isso influenciou de May de maneiras sutis, mas definidas, e agora ela influencia em seus sentimentos por Eddie que a abandona de maneira muito parecida com a de The Old Man, uma vez abandonou sua mãe. Eddie não vê a situação de abandono do sexo masculino da mesma perspectiva que May e devido a esta disparidade, eles interpretam o status de sua relação e situação atual de diferentes pontos de vista muitas vezes conflitante. Embora Eddie e May não sabiam que eles estavam relacionados, May sente vergonha do seu relacionamento com ele o qual continuou mesmo depois que Eddie e May souberam da relação de parentesco entre si. May tenta negar e ignorar o aspecto perturbador da sua relação familiar com Eddie que por outro 
lado parece ter aceitado este problema. Deixar Eddie partir permitiria a May poder continuar e superar Eddie, excluindo assim a vergonha do incesto.

May começa a reconhecer e desafiar a natureza defeituosa da identidade americana que Eddie representa num esforço de expor sua fantasia. Enquanto ela se sente inegavelmente atraida por Eddie (a dinâmica da relação deles varia entre um frágil devaneio e uma confrontação violenta), ela tenta resistir ao seu poder de controlá-la. Ela rebela-se quando ele revela a intenção de levá-la para Wyoming para sempre:

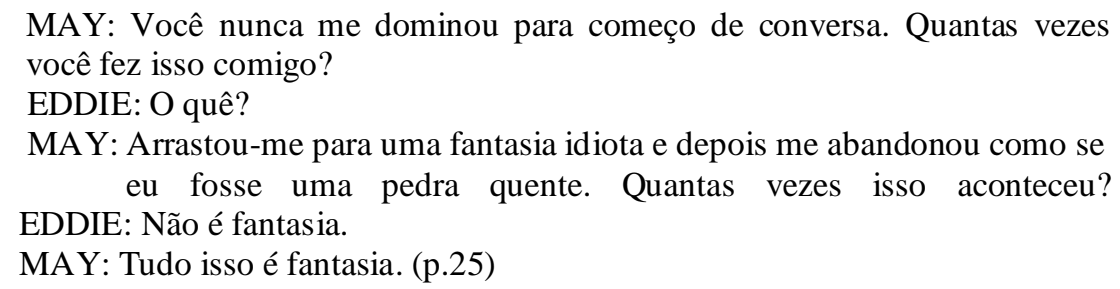

O reconhecimento de May da impossibilidade da visão de Eddie da identidade americana demonstra uma consciência que os personagens de Shepard nunca exibiram anteriormente. Para Shepard, esse reconhecimento marca um importante passo na recuperação da identidade. May move-se além de meramente reconhecer a ilusória construção do caráter americano personificada por Eddie, pois ela busca ativamente dissipar os falsos princípios que Eddie defende. Reagindo contra os desejos de Eddie de administrar uma fazenda, May grita "I hate chickens! I hate horses! I hate all that shit! You know that. You get me confused with somebody else. You keep comin' up here with this lame country dream life with chickens and vegetables and I can't stand any of it. It makes me puke to even think about it" (p. 25). May claramente rejeita a visão idealizada da vida americana por Eddie. Uma ação que sugere a natureza excludente e limitada do caráter americano. Nem todo americano deseja ou sonha ser um cowboy.

Essa admissão e reconhecimento do caráter americano da parte de May resultam nas revelações forçadas da 'verdade' dessa identidade. Eddie é compelido a reconhecer detalhes sobre o passado que previamente haviam sido suprimidos. Quando então a história passa a ser mais focada no The Old Man [The Old Man e Eddie representam uma outra versão da natureza cíclica e determinista do relacionamento pai/filho que apareceu anteriormente em outras peças de Shepard entre: Weston/Wesley, Dodge/Vince e Boy/Man (Rock Garden, 1968)]. A história de Eddie retrata "the male side a' this thing" (p.54), como The Old Man o descreve, controlando a história e manipulando os eventos para seus próprios propósitos. Mas May interfere no processo da narrativa, forçando Eddie a perceber que o passado que ele recorda é somente uma visão parcial da verdade. Ela explica para Martin que a história de Eddie contem tanto ficção como fatos:

MAY: Ele me contou aquela história umas mil vezes e ela sempre muda. EDDIE: Eu nunca me repito.

MAY: A única coisa que você faz é repetir a si mesmo. É tudo que você faz. Você caminha num grande círculo. (p. 26)

O comentário de May sugere a natureza cíclica da busca pelo caráter americano. Eddie fica preso ao mesmo padrão auto-destrutivo que aflige muitos dos personagens de Shepard reinscrevendo os próprios princípios que os levam a buscar a fuga. $\mathrm{O}$ relato de 
Eddie oferece uma desculpa para a conduta do The Old Man, que mantêm duas famílias separadamente, além de ter sido a causador da relação incestuosa entre Eddie e May. Ele é retratado solidariamente durante a narrativa de Eddie. De acordo com Eddie, The Old Man simplesmente "fell in love twice. That's basically how it happened. Once with my mother and once with her mother" (p. 48) A narrative de Eddie omite vários delitos cometidos pelo The Old Man, e convenientemente deixa de fora detalhes que provariam condenações do seu caráter.

May lança-se subitamente, interrompendo a história de Eddie para preenchê-la com os detalhes omitidos. Ela toma o controle da história, forçando The Old Man a protestar: 'Boy, is she ever off the wall with this one. You gotta' do somethin' about this (p. 53). Eddie e May começam a duelar com versões contraditórias da história, mas May começa a prevalecer na troca de 'farpas', forçando Eddie a confrontar os detalhes do passado que tanto ele como The Old Man gostariam de suprimir. May continua a revelar "the whole rest of the story" (p. 52), The Old Man ordena que Eddie a silencie: "Stand up! Get on your feet now goddammit! I wanna' hear the male side a' this thing. You gotta represent me now. Speak on my behalf. There's no one to speak for me now! Stand up!" (p. 54).

Profeticamente, The Old Man compreende corretamente que a rejeição de May da verdade parcial que ele e Eddie mantêm representa um desafio para a autoridade estabelecida dos dois e dos princípios que eles defendem. O fato de May denunciar "lame country dream life" de Eddie sugere o despertar de uma consciência que os personagens de Shepard começam a adquirir: a ilusão enganadora que sustenta a identidade americana como máscaras de comunhão nacional "the whole rest of the story". Ela refuta a noção de um caráter americano unificado que todos os cidadãos podem se identificar com e desejar.

Como um crítico afirma:

Central para a qualidade perturbadora e de sonho de Fool for Love é a presença de The Old Man, uma figura paterna que parece existir em simultâneo, mas em uma dimensão removida, da ação da peça. Ele é tanto um espectro surreal e um reforço da obsessão contínua de Shepard com sua herança pessoal e de seu pai. (DEROSE, 1986, p. 114)

A ambiguidade típica de Shepard e sua resistência em adotar uma resolução obscurecem os esforços de May em forçar Eddie e The Old Man a enfrentar a verdade. (O famoso comentário de Shepard: "a resolution isn't an ending; it's a strangulation." [LIPPMAN, 1984, p. 11]). Eddie aparentemente quebra o ciclo da linhagem que Shepard continuamente afirmou contribui grandemente para determinar a identidade.

Eddie encena sua fuga mais uma vez. Diz para May "only gonna be a second" (p. 56), e desaparece. "He's gone", May diz simplesmente enquanto coloca seus pertences numa mala. Assim que May parte, The Old Man fica no palco para suas últimas falas, parece sugerir que a autoridade estabelecida foi reafirmada e que May e Eddie vão violentamente reencontrar-se num outro quarto de motel decadente de uma localidade remota similar ao "the edge of the Mojave desert", (p. 19) que forma o pano de fundo para Fool for Love. Leslie Wade (1997, p. 122) afirma que a natureza cíclica da peça "is a disturbing feature of the drama, since it conveys a deterministic understanding of gender conflict". O final também sugere a influência inevitável do caráter americano. 
Eddie informa May, "You know we're connected, May. We'll always be connected. That was decided a long time ago". (p. 31) Seu aviso sinistro indica que a presença de uma visão idealizada do caráter nacional irá persistir. May mostra o desejo de revelar o resto da história, mas Eddie, o vaqueiro americano, fará com que sua presença seja sentida.

A dor de Shepard emaranhada em Fool for Love exerce uma conexão palpável com a platéia. A maioria das pessoas já experimentou a necessidade desesperada tanto de manter quanto de expulsar alguém de suas vidas de todos os meios possíveis. São os extremos que os personagens percorrem que faz com que a platéia aplauda porque eles ou não puderam ou não fariam a mesma coisa. É a compreensão daquela dor em comum que faz a identificação com os personagens ser ainda mais forte. Uma vez que muito da ação de Shepard tem lugar nas entre linhas, é bom para ver exatamente o que o autor tem em mente com sua ação repleta de silêncios.

Fool for Love representa um tipo de progresso para Shepard, que continua sua tentativa de reconciliar a ilusão da identidade americana com a realidade da vida americana. $\mathrm{O}$ desejo de confrontar a natureza ilusória da identidade americana é um importante primeiro passo, além de necessário, para qualquer tentativa de recobrar a identidade nacional ou individual.

Após a análise das três peças nas quais os personagens representam total ou parcialmente famílias nucleares e são referidas nesse presente estudo como peças familiares passo a explanar as conclusões a que cheguei.

\section{Conclusão}

Como foi visto nos capítulos anteriores fica claro que Sam Shepard recicla muito dos mesmos mecanismos em suas peças. É como se tentasse desacreditar o mito da família americana exaustivamente. O mito tradicional da família, especificamente nos Estados Unidos, é aquele composto da mãe, do pop, torta de maçã, gramados cuidadosamente aparados e cercas brancas: o mito que todas as famílias são felizes e funcionais. Esse mito é outra maneira de negarmos quem somos e de onde viemos e esse falso ideal da família americana foi passado de geração para geração além de ter sido retratado nas obras de Norman Rockwell e em shows populares da televisão tais como Ozzie e Harriet. Em Buried Child, Shelly provoca Vince ao aproximarem-se da casa do avô e menciona que a casa parece-se com o estilo Norman Rockwell. Ela pergunta sobre o leiteiro e sobre o cachorrinho Spot (SHEPARD, 1981, p. 83, 84).

Sam Shepard apresenta para a platéia a percepção estereotipada da vida familiar nas áreas rurais e nos subúrbios dos Estados Unidos. Quando o casal entra na casa descobrem que a família que lá habita está muito longe do ideal americano. Alcoolismo, incesto, infanticídio, abuso físico e verbal fazem parte das famílias de Shepard. Isso é o que Shepard apresenta como a realidade da família americana. Como Roudané (2002, p. 5) descreve o trabalho de Sam Shepard:

Apesar de mostrar nas suas mais de cinquenta peças uma variedade bastante rica de estilos de representação e preocupações culturais, seu assunto central 
é a família americana. Vítimas e vitimizadores, o perseguido e perseguidor competem por um espaço metafórico, psicológico e espiritual nas suas peças. Entretanto, as opções diminuem vagarosamente. Não existem sobreviventes reais, nem remissão da dor. Espaços são abertos e se provam intransponíveis. A necessidade governa. A ironia constantemente renasce dos desejos frustrados daqueles que obedecem à compulsão a qual eles desejariam resistir.

Na visão de Shepard da família americana, os habitantes estão desconectados um do outro e muito distantes do que poderíamos chamar de unidade familiar funcional. Ao contar essas histórias e estabelecer esses novos mitos, como ele os vê, ele não está somente desacreditando os mitos comuns, mas também enviando uma mensagem para os americanos aceitarem quem eles são e de onde eles realmente vieram. Ele quer que paremos de utilizar as noções tradicionais sobre o que é pensado sobre as famílias e aceitar a realidade do que a família é na verdade. Esses mitos tradicionais sobre a família são perpetuados pela desconstrução do passado e a negação da verdade.

Nas peças de Shepard um dos principais debates é travado na tentativa de descobrir o que é um mito de fato. Numa entrevista concedida a Carol Rosen (1993, p. 5) Shepard afirma: "a myth is a lie of the mind". Essa mentira que a pessoa diz para si e para outros sobre como as coisas costumavam ser são realmente as versões de como gostaríamos de lembrar o passado:

A obsessão com o "memoried world", usando a frase de Malkin é evidente no ritmo de abertura de True West. Uma peça sobre dois irmãos [...] que narra suas lembranças da família e da infância e revela ressentimentos e frustrações que cada um nutre. (KANE, 2002, p. 141).

Todos os personagens de Shepard têm 'coisas' nos seus passados que precisam ser arranjadas, organizadas ou consertadas. As mentiras da família são mais profundas: "As verdades enterradas do passado e reprimidas por anos consecutivos de negação e subterfúgio são fontes de desconexão na família" (ROUDANÉ, 2002, p. 289). Esse debate sobre quem lembra e quem é responsável também é posto em questão. Shepard tenta chamar nossa atenção para esse debate. Shepard estabelece a verdade e a ficção em lados opostos nesse debate com memórias e mitos que foram passados de geração para geração assim como as pistas que foram também deturpadas como verdades. Fotografias são frequentemente utilizadas por Shepard para mostrar que as faces sorridentes nas fotos mentem sobre o que está realmente acontecendo. Shepard apresenta para platéia o fato de que as pessoas nas fotos não contam a história completa e como resultado perpetuam o mito. Não importa o quão longe você corra, não será possível escapar de quem você é ou de onde você veio e não é possível escapar da sua hereditariedade ou legado. Você corre o risco de contaminar a sua herança, pois o filho se tornará um pai e uma maldição passará para outras mãos. Muitas das batalhas travadas em suas peças são entre o filho e o patriarca, mas o filho quer encontrar seu lugar no mundo, um mundo onde ele é herdeiro do pai. Como Shepard afirma:

Eu acho que existe sim um personagem, características, se você preferir chamá-las assim, que correm pelas famílias e que são inegáveis. Muitas pessoas se ferram porque tentam dizer que não são como o pai ou como a mãe. Não vou ser desse jeito. Quando de fato não há nada que possamos fazer sobre o assunto. (p. 8). 
Esse tema da inevitabilidade é utilizado por Shepard em seis peças familiares. Somente ao confrontar o passado, o passado verdadeiro, você será capaz de escapar repetindo e seguindo os passos dos seus ancestrais. A confrontação pode ajudar a quebrar o ciclo destrutivo da hereditariedade.

Shepard afirma que ao invés de lutar consigo mesmo ou contra seu legado existe uma única solução: "Acredito que não haja escapatória e que a sincera aceitação disso tudo leva a outra possibilidade. Mas a possibilidade de alguma maneira miraculosa de eu me tornar uma pessoa diferente é um engano, um jogo fútil que, na verdade, leva a insanidade" (p. 9). Shepard não mais tentará esconder os fantasmas do seu passado, ele agora os exibe em suas peças.

Os protagonistas de Shepard são sempre sugados de volta para família, destinados a repetir os mesmos erros do passado e serem transformados nos próximos patriarcas. Com o desacreditar do mito, Shepard força sua platéia a aceitar a realidade do passado, não importa o quão confusa ela seja. Na peça The Late Henry Moss (SHEPARD, 2000), o patriarca morre no palco na última cena. Henry morre somente depois de aceitar seu passado, ele verdadeiramente prestou contas sobre tudo que fez. Com essa peça parece que Shepard fechou o ciclo das peças familiares, pois ao contrário das peças anteriores os personagens aceitam seus passados. Eles também discutem sobre a reconciliação com outros personagens. Talvez seja uma tentativa de Shepard de deixar uma mensagem para seus leitores de que a reconciliação possa ser uma possível solução.

Shepard apresenta uma luta contínua com o paradoxo da identidade americana. Na sua carreira ele expôs de maneira exemplar a natureza ilusória da identidade nacional que promove imagens de um espírito pioneiro. Muitos dos comentários de Sam Shepard sustentam sua disputa onde ele lida com as mesmas questões da identidade americana que os seus personagens. Ele é fascinado com o oeste americano tanto fisicamente quanto com sua aura mítica. Em entrevistas ele sempre afirma que como veio do oeste americano nunca conseguirá definir-se fora daquele meio ambiente e sua conexão com a geografia do oeste lhe assegura que ele não poderá ser outra coisa além de um escritor americano. Quando Amy Lippman (1984, p. 12) o questiona sobre autores que o influenciaram, Shepard afirma detestar ir ao teatro. Quando ela menciona influências contemporâneas ele dispara:

Você alguma vez já esteve em um rodeio? Bem, existe mais drama acontecendo em um rodeio do que em cem peças que você vá assistir. É uma confrontação real, algo real que está acontecendo. Com uma platéia real que está envolvida ativamente. Você deveria ir a uns dois rodeios antes de ir ao teatro.

Sua afirmação que rodeios oferecem algo 'real' indica que as imagens de cowboy são genuínas e admiráveis - algo pelo qual podemos lutar. Um comentário que não deixa de ser irônico, a meu ver, pois um rodeio é um evento encenado, uma reprodução.

O trabalho de Shepard resistiu consistentemente ao conceito do Super Cowboy Man como o ideal americano. Alguns dos seus personagens ganham a habilidade de reconhecer a futilidade das suas buscas. Eles confrontam sua percepção da identidade americana ao reconhecer sua conexão com eventos passados tanto no nível individual como nacional. Desde 1990, após escrever States of Shock, os trabalhos de Shepard descrevem uma anulação da identidade que resulta de uma América na qual seus 
cidadãos perderam qualquer sentido de narrativa coletiva que os une como uma nação. Até agora, Shepard não ofereceu nenhuma substituição apropriada, mas seu trabalho passou por mudanças que indicam um afastamento da identidade do cowboy ao qual ele tão frequentemente esteve ligado. Ele continua procurando mostrar aos americanos que eles devem procurar por uma nova essência do mito, uma que esteja enraizada e genuinamente conectada aos seus ancestrais e a terra ao invés do American dream que é baseado numa mentira. E para incentivá-los a fazerem isso Shepard tenta convencer os americanos que eles precisam resistir à sedução dos comerciais que vendem uma imagem incompleta e ilusória da identidade americana e descobrir uma identidade que seja mais genuína.

Nos seus escritos, Samuel G. Freedman (1985, p. 1) afirma:

\begin{abstract}
A medida de realização no drama americano pode ser considerada a habilidade do escritor para colocar o retrato vivo de uma família dentro de um quadro social mais amplo - ou mais direto ao ponto, fazer com que a família represente não somente a vida mais íntima do escritor, mas um grupo de condições externas... E num ciclo de peças familiares estendendo-se por mais de uma década... Sam Shepard retratou uma imagem de desarmonia doméstica tão chocante quanto qualquer outro que o precedeu.
\end{abstract}

No seu ensaio The Family in Modern Drama, Arthur Miller (1996, p. 75) explora o tópico de alienação social que caracteriza um grande número de peças familiares européias e americanas, e afirma que "o mundo no qual vivemos é um lugar estranho". O dramaturgo toca no tópico da dimensão existencial do drama familiar: "Eu gostaria de fazer uma declaração ousada de que todas as peças que qualificamos como excelentes, sem mencionarmos as que chamamos de sérias, estão em última instância envolvidas com algum aspecto de uma única pergunta: Como pode um homem fazer do mundo exterior um lar? [...] Como pode um homem fazer para ele mesmo um lar naquela vastidão de estranhos e como ele pode transformar aquela vastidão em um lar?" (p. 73,85). Um dos temas principais das peças de Shepard é a alienação do homem no mundo moderno; uma busca fútil por um sentido de pertencer está no núcleo de todas essas peças. Seus personagens são exemplos perfeitos de indivíduos mal ajustados da sociedade moderna. Eles não estão em paz com o seu lugar no mundo, eles são desenraizados e agitados e estão numa busca desesperada por algum tipo de refúgio. E ao explorar essa luta do homem para adaptar-se ao mundo público ou sua inabilidade em encontrar um papel satisfatório na sociedade as peças de Shepard levantam questões existenciais importantes.

Uma marca registrada importante da cultura popular americana é a santidade do lar americano. É uma pré-concepção comum que a palavra 'lar' carregue conotações de refúgio e santuário, e muitos a associam com raízes. Como os negócios, política, diplomacia e outras áreas tornam-se cada vez mais 'selvagens', o homem procura por um paraíso na vida privada, nas relações pessoais e acima de tudo na família - o último refúgio de amor e decência. As arenas públicas e privadas coexistem e não podemos reconhecer seu funcionamento como independente. Dessa maneira, os sentimentos de alienação social espelham a inabilidade do homem em encontrar um consolo na esfera do lar e vice e versa. As forças econômicas são vistas como invasoras da esfera privada. Como Dodge sugere: "The house has been a pain in the neck ever since the very first mortgage" (p. 128). As peças podem ser interpretadas como verdadeiros ataques contra 
a sociedade competitiva e contra o sonho americano e a sua influência desumanizadora sobre a família.

A dimensão existencial das peças pode ser parcialmente discutida em relação ao poema The Waste Land escrito em 1922 por T. S. Eliot. Essas obras retratam um profundo desespero humano e podem ser interpretadas como uma crítica severa a civilização moderna. O poema está baseado na secura, na dureza e esterilidade da pedra associada à esterilidade do Ocidente, que perdeu a transcendência, a dimensão simbólica e a ideia do sagrado. De acordo com Eliot a humanidade está caminhando para o apocalipse, assim como as famílias das peças de Shepard. Tanto o mundo exterior, como o lar e como as mentes dos indivíduos podem ser comparadas a wastelands desertas.

Devido à rápida expansão da economia moderna, parece que as pessoas não sentem mais a conexão espiritual com a terra. Shepard vê o novo oeste, ao contrário do velho oeste, como o falecimento da cultura americana. Ele afirma: "Para mim, uma das maiores tragédias foi sairmos de uma sociedade agrícola para uma urbano-industrial na virada do século" (BOTTOMS, 1998, p. 156). A esterilidade da cultura de consumo americana - representando um sentido de decadência - também é retratada nas peças de Shepard refletindo a condição espiritual da família. Características típicas da casa da família são classificadas como: 'velha', 'pálida', 'desgastada', 'fora de moda', 'marrom', 'escura' (p. 63). O corpo de Dodge - cercado de "várias frascos pequenos com pílulas" (p. 63) - é um símbolo literal de deterioração, assim como Halie assinala: "Você senta aqui dia e noite, apodrecendo! Se decompondo! Infestando a casa com o seu corpo pútrido!" (p. 76). A peça pode ser comparada ao gênero gótico, pois está povoada por grotescos e seu humor permeado por pessimismo. Bradley, assim como o Fisher King em The Waste Land, com sua perna de madeira, sua impotência espiritual e sexual ecoa as feridas do Fisher King e sua ausência de potência sexual que leva a esterilidade das suas terras.

Depois de apontar ainda inúmeras pistas confusas, Shepard nunca resolve o enigma da criança enterrada. Quem foi o pai? Tilden? Ansel? Outra pessoa? Por que Dodge quis matá-lo? E por que ninguém reconhece Vince quando ele chega? Um verdadeiro mistério, Shepard sugere - por exemplo, como nós fomos escolhidos para nascermos em uma família particular, ou como nós saímos da maneira que somos e permanece um mistério. A única solução que a peça oferece é uma "impossível": que Vince e a criança enterrada são a mesma pessoa, cada um uma fantasia do que o outro poderia ter se tornado em diferentes circunstâncias. Como planetas em suas órbitas próprias, os membros da família nas peças de Shepard giram em torno um do outro sem nunca se cruzarem.

Suas peças são alegorias do amor mutilado, dando testemunho soberbo para memórias violentas, ditas de uma forma mais texturizada e um estilo de narrativa mais complexa do que a dos primeiros trabalhos de Shepard. Joseph Chaikin que lhe tinha ensinado as virtudes de reescrever as peças com perplexidade, a ausência de normalidade familiar: "O que aconteceu com essa família" (Buried Child), "Que tipo de família é essa?" (Curse of the Starving Class). O refrigerador em Curse of the Starving Class - que é vazio ou recheado com alimentos inadequados pelo embriagado Weston um símbolo do fiasco de criação. "Você não poderia ter tanta fome!", fala Weston. "Não somos tão maus, caramba!". 
Desde o início de sua carreira de escritor, o trabalho de Shepard revela que ele está mais interessado na consciência que na realidade. Suas peças são paisagens das emoções que contêm estados de espírito dentro do ego. Mais de ação dramática típica ou tipicidade e arco da história de uma peça tradicional, peças de Shepard como Fool for Love lembra o reino surreal e muitas vezes absurdo e contraditório dos sonhos ou o subconsciente. Seus personagens, como os de Fool for Love não tem falha trágica ou missão fatídica. Eles organizam-se através do tumulto emocional de suas vidas em uma luta de poder em que a identidade é vaga, o tempo é cíclico, e o passado assombra o presente. Como num sonho, as lembranças são muitas vezes idealizadas e alteradas para se adequar às necessidades do sonhador.

Tendo afastado seus breves momentos no palco, os homens violentos seguem suas fantasias na escuridão enquanto as mulheres destroem essas fantasias, a fim de iluminar seu próprio caminho. Mas é precisamente tais breves momentos de questionamento, breve resistência ao domínio de fantasias do sexo masculino, que dá aos trabalhos de Shepard sobre a família a sua complexidade como as fantasias centralistas dos homens que são postas em questão pelas ações e posições das mulheres. Os homens nas peças de Shepard que ferozmente lutam pelo centro do palco estão condenados, talvez, ele gostaria que nós acreditássemos, que estão gloriosamente condenados, mas condenados do mesmo modo. Ao escolher abandonar o palco, esse espaço para o comportamento destrutivo de seus homens, as mulheres nas peças de Shepard também escolhem a vida ao invés da morte, a esperança ao invés do desespero, re-criação ao invés de destruição. Se os padrões de comportamento aos quais os homens nas peças de Shepard se agarram trouxeram ao mundo a sua visão da América - a morte e destruição, parece que o abandono de tais mitos e uma invenção do novo é a única esperança para sobrevivência. Porque o mito nunca teve qualquer vantagem para as mulheres, as personagens femininas das obras estão dispostas e são capazes, de desviar o olhar da violência e autodestruição que os homens nas peças de Shepard querem glorificar. Dada as atividades que geralmente ocupam um lugar no centro do palco das peças, talvez a escolha mais sábia é aquela tomada por muitos de seus personagens mulheres, escapar para um mundo diferente.

Nas obras de Shepard encontramos uma vigente dissociação entre texto e cena e que pode ser considerada benéfica em suas peças. Uma transformação genuína na forma dramática, um alargamento do drama nos sentidos da vida social e íntima. Movendo-se em direção a uma maior subjetividade da forma dramática. A dimensão da intimidade que não é o 'privado', o 'doméstico' - tornou-se cada vez mais importante. Não se trata de esquecer ou expulsar Brecht, mas de colocá-lo em tensão com Strindberg e sua dramaturgia da cena doméstica. Brecht rejeitou a parte da intimidade. Ele mesmo dizia não ter ferramentas para responder a tais questões que, na verdade, não o interessavam. Ele se destacava pela forma genial como captava o comportamento social dos homens. Em Shepard, o texto dramático encontrou, na sua própria incompletude, a sua abertura. Nas peças existe um vazio que chama o palco, a relação com o espectador. Seus textos têm a forma aberta, que não só expressa o desejo pela cena, pelos atores, pelo público, mas também reinventa essa relação. Talvez possamos encontrar nas obras de Shepard um teatro que realize a fusão do social, do político e da psicanálise - como se discurssasse sobre o inconsciente.

Por meio de peças como Curse of the Starving Class, Buried Child e Fool for Love Shepard pode finalmente estar sinalizando a maneira pela qual o drama americano 
contemporâneo se recusa a ser limitado por mais tempo em qualquer conteúdo ou estilo. É um projeto no qual ele ajudou a liderar o caminho, pelo casamento de ambições radicais com a forma tradicional.

\section{REFERÊNCIAS BIBLIOGRÁFICAS}

ABLON, Joan. Irish-American Catholics in a West Coast Metropolitan Area. The American Experience with Alcohol. 395-410, 1985.

ADLER, Thomas P. Curse of the Starving Class. Educational Theatre Journal 29. 40910, 1977.

ADLER, Thomas P. Mirror on the Stage: The Pulitzer Prize Plays as an Approach to American Drama. West Lafayette: Purdue University Press, 1987.

AMIDON, Rick E. An American Odyssey: Kinship and Cowboys in Sam Shepard's Drama. DAI 47. 4388A. Michigan State University, 1986.

ANSEN, David. The Reluctant Star. Newsweek 24 Nov. 117-118, 1980.

ARMENS, Sven. Archetypes of the Family in Literature. Seattle: U. Of Washington Press, 1966.

AUERBACH, Doris. Who was Icaru's Mother? The Powerless Mother Figures in the Plays of Sam Shepard. Sam Shepard: em Kimball King, ed., Sam Shepard: A Casebook. New York: Garland, 53-64,1988.

BAUDRILLARD, Jean. Simulacros e Simulações. Lisboa: Relógio d’água, 1991.

BENNET, Linda e AMES,Genevieve M. eds. The American Experience with Alcohol: Contrasting Cultural Perspectives. New York: Plenum Press, 1985.

BIGSBY, C. W. E. A Critical Introduction to twentieth Century Drama 3: Beyond Broadway. Cambridge: Cambridge University Press, 1985.

BLAU, Herbert. Comedy since the Absurd. Modern Drama 25. 545-568, 1982.

BLAU, Herbert. The American Dream in American Gothic: The Plays of Sam Shepard and Adrienne Kennedy. Modern Drama 27: 520-539, 1984.

BLOOM, Harold. O’NEILL, Eugene. Long Day's Journey into Night. Yale University Press, 1989.

BRADSHAW, John. Bradshaw on: The Family. Deerfield Beach, F1. : Health Communications, Inc., 1988.

BRATER, Enoch. American Clocks: Sam Shepard's Time Plays. Contemporary Theater Review, Vol. 8, Part 4, pp. 19-28, 1998.

BROOKHOUSE, Christopher. Story Itself. Sam Shepard: A Casebook. 65-72, 1988. 
BOTTOMS, Stephen J. The Theatre of Sam Shepard: States of Crisis. Cambridge: Cambridge University Press, 1998.

BURK, Robert Eugene, Jr. Reading Shepaard and Lacan: A Dramaturgy of the Subject. DAI 47: 4236A. University of Washington, 1986.

CALLENS, Johan. Memories of the Sea in Shepard's Illinois. Modern Drama 29: 403-415, 1986.

CHAIKEN, Joseph and Sam Shepard. Letters and Texts, 1972-1984. New York: New American Library, 1989.

CHUBB, Kenneth and the Editors of Theatre Quarterly, Metaphors, Mad Dogs and Old Time. Cowboys: Interview with Sam Shepard. American Dreams. 187-209, 1981.

CIMA, Gay Gibson. Shifting Perspectives: Combining Shepard and Rauschenberg. Theatre Journal 38: 67-81, 1986.

COE, Robert. Image Shots are Blown: The Rock Plays. American Dreams. 57-66, 1981.

COHN, Ruby. New American Dramatists 1960-1980. Grove Press Modern Dramatists. New York : Grove Press, Inc., 1982.

COLLINS, Robert Hammond. American Realism and the Plays of Sam Shepard: A Study of Theme and Form. Dissertation Abstracts International (45/08) 2526; Ph.D.: University of Minnesota; 1984.

CRUM, Jane Ann. Notes on Buried Child. KING, Kimball. Sam Shepard: A: Casebook. New York: Garland, 73-80, 1988.

DANIELS, Barry, ed. In Front of you Is the Moon: Correspondence and texts by Joseph Chaikin and Sam Shepard. New York: Sun and Moon, 1988.

DARDIS, Tom. The thirsty Muse: Alcohol and the American Writer. New York: Ticknor and Fields, 1989.

DENBY, David. A Stranger in a Strange Land: A Moviegoer at the Theatre. Atlantic Monthly Jan. 1985: 45.

DEROSE, David. Slouching towards Broadway: Shepard's A Lie of the Mind. Theatre 17, Spring: 69-74, 1986.

DEUTSCH, Charles. Broken Bottles, Broken Dreams: Understanding and Helping the Children of Alcoholics. New York: Teachers College Press, 1982.

EARLEY, Michael. Of Life Immense in Passion, Pulse, and Power: Sam Shepard and the American Literary Tradition. American Dreams. 126-132, 1981. 
ECO, Umberto. Viagem pela hiper-realidade. In: Viagem na irrealidade cotidiana. Rio de Janeiro: Nova Fronteira, 1984.

ELIOT, T. S. The Waste Land. In Nina Baym, et al., ed., The Norton Anthology of American Literature, Volume D. New York: W.W. Norton, 1430-1443, 2003.

ERBEN, Rudolf. Women and Other Men in Sam Shepard's Plays. Studies in American Drama, 1945-Present 2: 29-41, 1987.

FALK, Florence. The Role of Performance in Sam Shepard's Plays. Theatre Journal 33: 182-198, 1981.

FALK, Florence. Men without Women: The Shepard Landscape. American Dreams. 90-103, 1981.

FENNEL, Patrick. Sam Shepard: The Flesh and Blood of Theatre. DAI 38: 3145A. University of California, Santa Barbara, 1977.

FREEDMAN, Samuel G. Sam Shepard's Mythic Vision of the Family. New York Times 1 Dec. B1, B20, 1985.

FRUTKIN, Ren. Paired Existence Meets the Monster. American Dreams. 108-116, 1981.

GASSNER, John. Best American Plays of the Early American Theatre from the Beginning to 1916. New York: Crown Publishers, Inc., 1967.

GELBER, Jack. The Playwright as Shaman. American Dreams. 45-48, 1981.

GENDRICH, Cynthia. e HATTERY, Angela. Borderless Academe: Families in Crisis and A lie of the Mind. Project Muse. 2005.

GILMAN, Richard. Introduction. Seven Plays. By Sam Shepard. New York: Bantam Books, 1981.

GILMORE, Thomas B. Equivocal Spirits: Alcoholism and Drinking in TwentiethCentury Literature. Chapel Hill: University of North Carolina Press, 1987.

GOLDBERG, Robert. Sam Shepard: Off-Broadway's Street Cowboy. Rolling Stone College Papers. 1980 Dec; 43-45.

HADOMI, Leah. The Homecoming Theme in Modern Drama: The Return of the Prodigal. Lewiston: Edwin Mellen Press, 1992.

HARDWICK, Elizabeth. An Introduction: La Turista. American Dreams. 67-71, 1981.

HART, Lynda Lee. Sam Shepard's Metaphorical Stages. NY: Greenwood Press; 1987. 
KAKUTANI, Michiko. Myths, Dreams, Realities - Sam Shepard's America. New York Times 29 January: B1, B26-28, 1984.

KING, Kimball, ed. Sam Shepard: A Casebook. Casebooks on Modern Dramatists No. 2. New York: Garland Publishing, Inc., 1988.

KLEB, William. Sam Shepard's Free-for-All: Fool for Love at the Magic Theatre Theatre 14.3: 77-82, 1983.

KLEB, William. Sam Shepard. American Playwrights since 1945. 387-419, 1989.

KLEB, William. Who's That Tall, Dark Stranger? Newsweek 11 Nov. 68-73, 1985.

KLEB, William. Worse than Being Homeless: True West and the Divided Self. Em MARRANCA, American Dreams. 117-125, 1981.

KOLIN, Philip C. American Playwrights Since 1945: A Guide to Scholarship, Criticism, and Performance. New York: Greenwood Press, 1989.

KREYCHE, Gerald F. Visions of the American West. University Press of Kentucky, 2009.

KROLL, Jack. Savage Games People Play. Newsweek 16 Dec.: 85, 1985.

KRONBLUM, William e JULIAN, Joseph. Social Problems. $5^{\text {th }}$ Edition. Englewood Cliffs, N.J, 2001.

LAWSON, Gary e PETERSON. James S. e LAWSON, Ann. Alcoholism and the Family: A Guide to Treatment and Prevention. Rockville, md. : Aspen Systems, 1983.

LION, John. Rock 'n Roll Jesus with a Cowboy Mouth. American Theatre. April: 48, 1984.

LIPPMAN, Amy. Rhythm and Truths: An Interview with Sam Shepard. American Theatre. April: 9-13, 40-41, 1984.

LEMAY, Leo. The Autobiography of Benjamin Franklin, 1997.

LEVY, Jacques. Em BLOOM's Major Dramatists: Sam Shepard, Infobasing Publishing, 2003.

LONDON, Todd. Theatre on the Couch. American Theatre 6.2 : 22-25, 1989.

LONDRE, Felicia. Sam Shepard Works Out: The Masculinization of America. Studies in American Drama 1945-Present 2: 19-26, 1987.

MALKIN, Jeanette R. Memory-theater and postmodern drama. Sam Shepard and the Anxiety of Erasure: 115-154. Michigan University, 1999. 
MANHEIM, Michael. The Cambridge Companion to Eugene O'Neill. Cambridge: Cambridge University Press, 1998.

MANN, Bruce. Character Behavior and the Fantastic in Sam Shepard's Buried Child. Sam Shepard: A Casebook. 81-94, 1988.

MARRANCA, Bonnie. e DASGUPTA, Guatam . American Playwrights: A Critical Survey. New York: Drama Book, 1981.

MARRANCA, Bonnie, ed. American Dreams: The Imagination of Sam Shepard. New York: Performing Arts Journal Publications, 1981.

MCDONOUGH, Carla J. Staging Mascukinity: Male Identity in Contemporary American Drama. By McFarland, 1997.

MCGHEE, James Hamill. The Architecture of the Fantastic in the Plays of Sam Shepard. DAI 44: 0912A. Bowling Green State University, 1984.

METZGER, Lawrence. From Denial to Recovery: Counseling Problem Drinkers, Alcoholics, and Their Families. San Francisco: Jossey-B ass Publishers, 1988.

MILLER, Arthur. The Family in Modern Drama. em The Theater Essays of Arthur Miller. Robert A. Martin (Editor), Steven R. Centola (Editor), 1996.

MILLER, Arthur. All My Sons. Em Arthur Miller's Collected Plays, Vol. I. New York: The Viking Press, 57-127, 1957.

MILLER, Arthur. Death of a Salesman. New York: Penguin, 1977.

MOORE, John Joseph. A Phenomenological Approach to the Aesthetic Receptivity of a Dramatic Art Work. DAI 43: 05A. SUNY, Buffalo, 1982.

MOTTRAM, Ron. Exhaustion of the American Soul: Sam Shepard's A Lie of the Mind. Sam Shepard: A Casebook. KING, 95-106, 1988.

MOTTRAM, Ron. Inner Landscapes: The Theatre of Sam Shepard. A Literary Frontiers Edition. Columbia: University of Missouri Press, 1984.

MURPHY, Brenda, and Susan C.W. Abbotson. Understanding Death of a Salesman. Westport, Conn.: Greenwood Press, 1999.

NORWOOD, Robin. Women Who Love Too Much. Pocket Books. New York: Simon and Schuster, 1985.

O'NEILL, Eugene. Ah, Wilderness! In The Plays of Eugene O'Neill. New York: Random House, 1934.

O'NEILL, Eugene. Desire Under the EIms. In Nine Plays by Eugene O'Neill. New York: The Modern Library, 135-206, 1932. 
O'NEILL, Eugene. The Hairy Ape. In Four Plays by Eugene O'Neill. New York: Signet Classic, 247-308, 1998.

O’NEILL, Eugene. Long Day's Journey into Night. New Haven: Yale University Press, 2002.

ORBISON, Tucker. Mythic Levels in Shepard's True West. Modern Drama 31:175 $-183,1988$.

OUMANO, Ellen. Sam Shepard: the Life and Work of an American Dreamer, 1986.

PAOLINO, Thomas J. e MCCRADY, Barbarba S. The Alcoholic Marriage: Alternative Perspectives. 1977.

PARSONS, Talcott. The American Family: Its Relations to Personality and to the Social Structure. Em PARSONS, Talcott e BALES, Robert F. . Family, Socialization and Interaction Process. Glencoe, Illinois: The Free Press, 3-33, 1955.

PARSONS, Talcott. O sistema das Sociedades Modernas. Ed. Pioneira.1974.

PATRAKA, Vivian M. e SIEGEL, Mark. Sam Shepard. Western Writers Series 69. Boise, Id.: Boise State University, 1985.

PEREZ, Joseph F. Coping within the Alcoholic Family. Muncie, Ind.: Accelerated Development, 1986.

PORTER, Thomas. Myth and Modern American Drama. Wayne State UP, 1969.

PUTZEL, Steven. Expectation, Confutation, and Revelation: Audience Complicity in the Plays of Sam Shepard. Modern Drama 30 (June): 147-160, 1987.

RABILLARD, Sheila. Sam Shepard: Theatrical Power and American Dreams. Modern Drama 30 (Mar.): 58-71, 1987.

RABILLARD, Sheila. Destabilizing Plot, Displacing the Status of Narrative: Local Order in The Plays of Pinter and Shepard. Theatre Journal 43.1: 41-58, 1991.

RANDALL, Phyllis R. Adapting to Reality: Language in Shepard's Curse of the Starving Class. Sam Shepard: A Casebook. 121-134, 1988.

REISS, Ira L. The Family System in America. New York: Holt, Rinehart and Winston, Inc., 1971.

ROBINSON, James A. Buried Children: Fathers and Sons in O'Neill and Shepard. In Marc Maufort, ed., Eugene O'Neill and the Emergence of American Drama. Amsterdam: Rodopi, 151-158, 1989.

ROSEN, Carol. Emotional Territory: An Interview with Sam Shepard. Modern Drama 36: 1-11, 1993. 
ROSENBERG, Harold. Art on the Edge. University of Chicago Press,"Reality Again: The New Photorealism" (p. 237/239), 1975.

ROSEFELDT, Paul. The Absent Father in Modern Drama. New York: Peter Lang, 1995.

ROUdAnÉ, Matthew. The Cambridge Companion to Sam Shepard. C. University Press, 2002.

SCANLAN, Tom. Family, Drama, and American Dreams. Contributions in American Studies 35, 1978.

SCHMIDT, Kerstin. The Theater of Transformation: Postmodernism in American Drama, New York, 2005.

SESSUMS, Kevin. Geography of a Horse Dreamer: Playwright, Actor and Movie Director Sam Shepard. Interview September: 70-78, 1988.

SCHVEY, Henry I. A Worm in the Wood: The Father-Son Relationship in the Plays of Sam Shepard. Modern Drama 36: 12-26.50, 1993.

SHEA, Laura. The Family of Violence in the Dramas of O'Neill, Albee, and Shepard. DAI 44: 3384A. Boston University, 1984.

SHEPARD, Sam. American Experimental Theatre Then and Now. Reimpresso em American Dreams. 212-213, 1981.

SHEPARD, Sam. Language, Visualization and the Inner Library. Reimpresso em American Dreams. 214-219, 1981.

SHEPARD, Sam. A Lie of the Mind. New York: NAL books - New American Library, 1986.

SHEPARD, Sam. Buried Child. Seven Plays. New York: Bantam Books, 61-132, 1981.

SHEPARD, Sam. Curse of the Starving Class. Seven Plays. 133-200, 1981.

SHEPARD, Sam. Fool for Love. Fool for Love and Other Plays. New York: Bantam Books, 17-57, 1984.

SHEPARD, Sam. Hawk Moon: A Book of Short Stories, Poems, and Monologues. Los Angels: Black sparrow Press, 1973.

SHEPARD, Sam. Motel Chronicles. San Francisco: City Lights, 1982.

SHEPARD, Sam. Rolling Thunder Logbook. New York: Viking, 1977.

SHEPARD, Sam. True West. Seven Plays. 1-59, 1981. 
SHEPARD, Sam. Cruising Paradise. New York: Alfred A. Knopf, 1996.

SHEPARD, Sam. Holy Ghostly. The Unseen Hand and Other Plays. New York: Vintage Books, 1972.

SHEPARD, Sam. The Late Henry Moss. The Late Henry Moss; Eyes for Consuela; When the World Was Green: Three Plays. New York: Vintage Books, 2002.

SHEWEY, Don. "Rock-and Roll Jesus with a Cowboy Mouth (Revisited)." American Theatre 4: 20-25, 83-84, 2004.

SIEGEL, Ed. Prime time for drama. Boston Globe. Feb. 3: 47:4, 1995.

SIMARD, Rodney. Postmodern Drama: Contemporary Playwrights in America and Britain. Lanham, MD: University Press of America, 1984.

SLOTKIN, Richard. Regeneration Through Violence: the Mythology of the American Frontier, 1600-1860. W. University Press, 1973.

STEINGLASS, Peter e BENNETT, Linda A. e WOLIN, Steven J. e REISS, David. The Alcoholic Family York: Basoc Books, 1987.

STEINKE, Lauri B. Visiting the Iniquity of the Fathers Upon the Children: Spiritual Retribution in Shepard's Family Trilogy and Fool for Love. Publications of the Arkansas Philological Association. 19.2: 73-84, 1993.

TAGER, Michael Edward. Crisis and Revitalization in American Thought and Politics. DAI 46: 11A. University of North Carolina at Chapel Hill, 1985.

TOMPKINS, Jane P. West of Everything: the Inner Life of Westerns, 1993.

WADE, Leslie A. Shepard and the American Theatre. Westport, CT: Greenwood Press, 1997.

WAKEFIELD, Thaddeus. The Family in Twentieth-Century American Drama. New York: Peter Lang, 2003.

WEALES, Gerald. American Theatre Watch, 1978-1979. Georgia Review. Sep; 569-81, 1979.

WEALES, Gerald. The Transformations of Sam Shepard em MARRANCA, ed., American Dreams: the Imagination of Sam Shepard, 1981.

WEGSCHEIDER, Sharon. Another Chance: Hope and Health for the Alcoholic Family. Palo Alto: Science and Behavior Books, 1981.

WETZSTEON, Ross. Introduction. Fool for Love and Other Plays by Sam Shepard. New York: Bantam, 1-15, 1984.

WHITING, Charles G. Digging up Buried Child. Modern Drama 31: 548-556, 1988. 
WHITING, Charles G. Food and Drink in Shepard's Theatre. Modern Drama 31: 175-183, 1988.

WHITING, Charles G. Images of Women in Shepard's Theatre. Modern Drama 33: 494-506, 1990.

WILLIAMS, Megan. Nowhere Man and the Twentieth-Century Cowboy: Images of Identity and American History in Sam Shepard's True West. Modern Drama, 40 (Spring 1997): 57-73.

WILCOX, Leonard. Language and Desire: The Abject in Shepard's Red Cross. Em King, Kimball. Sam Shepard: A Casebook. New York: Garland; c1988: pp. 107-120. (Casebooks on Mod. Drama; v. no. 2), 1988.

WILHEIN, Albert E. Icarus's Mother: Creative Transformations of a Myth. Em King, Kimball. Sam Shepard: A Casebook. New York: Garland; c1988: pp. 21-30. (Casebooks on Mod. Drama; v. no. 2), 1988.

WILSON, Ann. Great Expectations: Language and the Problem of Presence in Sam Shepard's Writing. Sam Shepard: A Casebook. 135-153, 1998.

WILSON, Ann. Fool of Desire: The Spectator to the Plays of Sam Shepard. Modern Drama 30: 46-57, 1987.

WOITITZ, Janet G. Adult Children of Alcoholics. Deerfield Beach, Fl.: Health Communications, Inc., 1983.

WOOD, Barbara L. Children of Alcoholism: The Struggles for Self and Intimacy in Adult Life. New York: New York University Press, 1987.

ZINMAN, Toby Silverman. Sam Shepard and Super Realism. Modern Drama 29: 423-429, 1986.

ZINMAN, Toby Silverman. Shepard Suite. American Theatre 1. 8: 15-17, 1984. 
